\title{
Vodenje sprememb v zdravstvenih organizacijah
}

Romana Martinčič Roberto Biloslavo 
University of Primorska Press

Editorial Board

Katarina Babnik

Štefan Bojnec

Aleksandra Brezovec

Boris Horvat

Dejan Hozjan

Alenka Janko Spreizer

Alen Ježovnik

Lenka Kavčič

Alan Orbanič

Gregor Pobežin

Andraž Teršek

Jonatan Vinkler
Faculty of Management Monograph Series

Editor in Chief

Matjaž Novak

Editorial Board

Ana Arzenšek

Štefan Bojnec

Dubravka Celinšek

Armand Faganel

Viktorija Florjančič

Borut Kodrič

Suzana Laporšek

Mirko Markič

Franko Milost

Matjaž Nahtigal

Mitja Ruzzier

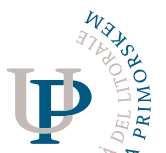

UNIVER Z 


\section{Vodenje sprememb v zdravstvenih organizacijah}

Primer slovenskih bolnišnic

Romana Martinčič

Roberto Biloslavo 
Vodenje sprememb $v$ zdravstvenih organizacijah: Primer slovenskih bolnišnic Romana Martinčič

Roberto Biloslavo

Recenzenta

Marko Ferjan

Samo Pavlin

Jezikouni pregled: Davorin Dukič

Prelom in priprava za izdajo: Jonatan Vinkler

Izdala

Založba Univerze na Primorskem

(za založnika: prof. dr. Dragan Marušič, rektor)

Titov trg 4, SI-600o Koper

Glavni urednik

Jonatan Vinkler

Vodja založbe

Alen Ježovnik

Koper 2017

ISBN 978-96I-7023-47-3 (pdf)

http://www.hippocampus.si/ISBN/978-96I-7023-47-3.pdf

ISBN 978-96I-7023-48-o (html)

http://www.hippocampus.si/ISBN/978-96I-7023-48-o/index.html

DOI: https://doi.org/I0.26493/978-96I-7023-47-3

(C) 2017 Univerza na Primorskem

Izdaja je sofinancirana po pogodbi ARRS za sofinanciranje izdajanja znanstvenih monografij v letu 2017.

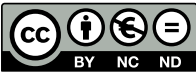

Kataložni zapis o publikaciji (CIP) pripravili v Narodni in univerzitetni knjižnici v Ljubljani

COBISS.SI-ID $=293150720$

ISBN $978-961-7023-47-3$ (pdf)

ISBN 978-961-7023-48-0 (html) 


\section{Vsebina}

\section{Slike $\bullet 9$}

\section{Preglednice • II}

\section{Krajšave • I3}

\section{Uvod • I5}

\section{Vodenje in spreminjanje $\mathbf{v}$ zdravstvenih organizacijah $\bullet$ 3I}

Managemet in vodenje - komplementarnost dveh procesov $\bullet 32$

Kaj je vodenje? $\bullet 35$

Vodenje kot proces $\bullet$ 40

Se vodja rodi ali naredi? $\bullet 43$

Vodenje sprememb $\bullet 45$

Narava in koncepti spreminjanja $\bullet 48$

Odpori proti spremembam $\bullet \mathbf{5 3}$

Razlogi za neuspeh pri uvajanju sprememb • 55

Spreminjanje organizacijske kulture $\bullet \mathbf{5 9}$

Vrste sprememb v organizacijah $\bullet 60$

Vodenje sprememb v zdravstvenih organizacijah $\bullet 63$

\section{Teorije in stili vodenja $\bullet 69$}

Teorija osebnih značilnosti $\bullet 70$

Vodenje in kompetence $\bullet 73$

Vedenjski modeli $\bullet 76$

Situacijski modeli $\bullet 78$

Transformacijsko vodenje $\bullet 8$ I 
Transakcijsko vodenje $\bullet \mathbf{8 4}$

Vodenje laissez-faire $\bullet 85$

Vodenje in čustvena inteligenca $\bullet 85$

Avtentično vodenje $\bullet 88$

\section{Značilnosti nekaterih modelov managementa sprememb • 9I}

Lewinov osnovni model $\bullet 92$

Kotterjev procesni model $\bullet 94$

Burke-Litwinov model • 96

Strategije managementa sprememb • 99

Strategije organizacijskih sprememb v zdravstvu $\bullet$ IO2

Strategije za zmanjšanje odporov $\bullet$ IO4

\section{Model izvajanja sprememb v bolnišnicah • I07}

Povezava med stili vodenja in vrstami sprememb • I07

Konceptualni model • III

\section{Metodološki in konceptualni okvir raziskave • II5}

Metodološka izhodišča raziskave • II5

Konceptualni okvir raziskave $\bullet$ II7

Operacionalizacija konstruktov • I2O

Stili vodenja $\bullet \mathbf{I} 20$

Vrste sprememb • I2I

Uspešnost uvedene spremembe $\bullet \mathbf{I} 2 \mathbf{I}$

Priprava vprašalnika $\bullet 122$

Opis vzorca • 123

Metode zbiranja podatkov $\bullet \mathbf{I 2 4}$

Metode analiziranja podatkov • I25

\section{Empirična raziskava $\bullet 129$}

Analiza, rezultati in ugotovitve kvalitativne raziskave • I29

Opredelitev temeljnih in perifernih dejavnosti v bolnišnicah • 129

Področja in vrste radikalnih sprememb • I35

Področja in vrste inkrementalnih sprememb • 139

Značilnosti procesov spreminjanja $\bullet$ I4I

Pristopi k vodenju sprememb $\bullet \mathbf{I 5 O}$

Ključni elementi vodenja v procesih spreminjanja • I52

Povzročitelji sprememb v bolnišnicah • 153

Analiza, rezultati in ugotovitve kvantitativne raziskave • 154

Analiza vzorca kvantitativne raziskave $\bullet \mathbf{I 5 4}$

Analiza komponent posameznih konstruktov $\bullet$ I58

Faktorska analiza merjenih spremenljivk $\bullet 164$

Zanesljivost faktorjev $\bullet$ I $7 \mathbf{I}$ 
Opisne statistike posameznih konstruktov $\bullet \mathbf{I 7 3}$

Rezultati regresijske analize $\bullet \mathbf{I 8 3}$

Preverjanje hipotez $\bullet \mathbf{I 9 3}$

Primerjava rezultatov s sorodnimi raziskavami • 196

\section{Sklep • 20I}

\section{Literatura • 207}

\section{Recenziji • 223}

$$
\text { I } \cdot 223
$$

II • 225 



\section{Slike}

33 Slika I: Primerjava med managementom in vodenjem

34 Slika 2: Primerjava med managementom in vodenjem v neprofitnih organizacijah

42 Slika 3: Okvir za razumevanje vodenja

46 Slika 4: Ogrodje za vodenje

51 Slika 5: Primer preproste analize silnic

58 Slika 6: Faktorji tveganja v javnem sektorju

62 Slika 7: Vrste sprememb

64 Slika 8: Tipologija vodstvenih stilov

77 Slika 9: Model mrežnega vodenja

79 Slika ı: Fiedlerjev kontingenčni model

80 Slika II: Model Herseya in Blancharda

96 Slika I2: Burke-Litwinov model managementa sprememb

97 Slika I3: Transformacijski dejavniki

98 Slika I4: Transakcijski dejavniki

I03 Slika 15: Teorije organizacijskih sprememb

Io8 Slika 16: Pristopi k spreminjanju v primeru inkrementalne spremembe

I09 Slika 17: Pristopi k spreminjanju v primeru fundamentalne spremembe

IIO Slika I8: Kontinuum spreminjanja

III Slika I9: Konceptualni model stilov vodenja glede na vrsto spremembe

II2 Slika 20: Konceptualni teoretični model izvajanja sprememb v bolnišnicah

I59 Slika 21: Konstrukti vrste sprememb s predpostavljenimi indikatorji

168 Slika 22: Kolenski diagram

198 Slika 23: Ugotovljeni stili vodenja glede na vrsto spremembe

199 Slika 24: Vodenje sprememb v bolnišnicah vezano na ugotovitve raziskave

200 Slika 25: Alternativni model vodenja sprememb v bolnišnicah 



\section{Preglednice}

57 Preglednica I: Io glavnih ovir za uspešne spremembe v bolnišnicah

70 Preglednica 2: Raziskave osebnih značilnosti in karakteristik vodij

72 Preglednica 3: Lastnosti in značilnosti kliničnih vodij

72 Preglednica 4: Lastnosti in značilnosti kliničnih vodij - rangirane po pomembnosti

I55 Preglednica 5: Struktura anketirancev glede na spol

I55 Preglednica 6: Struktura anketirancev glede na starost

I56 Preglednica 7: Spol ocenjevane osebe

156 Preglednica 8: Starost ocenjevane osebe

I57 Preglednica 9: Vloga anketirancev med uvajanjem sprememb

157 Preglednica Io: Vključenost v izvajanje sprememb

158 Preglednica II: Razvrstitev anketirancev glede na vrsto bolnišnice

I59 Preglednica I2: Opisne statistike za posamezne indikatorje merjene spremenljivke sprememb

I6I Preglednica I3: Opisne statistike za merjene indikatorje spremenljivke uspešnost

165 Preglednica 14: KMO- in Bartlettov test sferičnosti za spremembe

166 Preglednica 15: Komunalitete za spremembe

167 Preglednica 16: Celotna pojasnjena varianca za spremembe

168 Preglednica 17: Faktorske uteži za merjene spremenljivke sprememb

170 Preglednica I8: KMO- in Bartlettov test sferičnosti za uspešnost

I70 Preglednica 19: Celotna pojasnjena varianca za uspešnost

I70 Preglednica 20: Komunalitete za uspešnost

171 Preglednica 21: Faktorske uteži za uspešnost

17I Preglednica 22: Cronbach $\alpha$ koeficient za posamezne spremenljivke kot celote

172 Preglednica 23: Koeficient Cronbach $\alpha$ za spremenljivko LF-vodenje

172 Preglednica 24: Koeficient Cronbach $\propto$ za spremenljivko management z izjemami pasivni

172 Preglednica 25: Koeficient Cronbach a za posamezne delne konstrukte 
174 Preglednica 26 Opisne statistike za vrste sprememb

174 Preglednica 27: Test Kolmogorov-Smirnova za vrste sprememb

175 Preglednica 28: Opisne statistike za posamezne faktorje vodenja

175 Preglednica 29: Test Kolmogorov-Smirnova za posamezne faktorje vodenja

176 Preglednica 30: Opisne statistike za stile vodenja

177 Preglednica 31: Test Kolmogorov-Smirnova za stile vodenja

177 Preglednica 32: Opisne statistike za uspešnost

178 Preglednica 33: Test Kolmogorov-Smirnova za uspešnost

I78 Preglednica 34: Stili vodenja glede na spol

179 Preglednica 35: T-test za neodvisne vzorce

I80 Preglednica 36: Vrste sprememb glede na vlogo

18I Preglednica 37: Stili vodenja glede na vlogo

I8I Preglednica 38: Kategoriji uspešnosti

I82 Preglednica 39: Test neodvisnih vzorcev

183 Preglednica 40: Test Kolmogorov-Smirnova za reziduale

I83 Preglednica 4r: Koeficienti asimetričnosti in sploščenosti

I84 Preglednica 42: Pojasnjenost regresijskega modela za uspešnost

I84 Preglednica 43: ANOVA za uspešnost

I84 Preglednica 44: Regresijski koeficienti za uspešnost

I85 Preglednica 45: Pojasnjenost regresijskega modela za IT-spremembe

I86 Preglednica 46: ANOVA za IT-spremembe

I86 Preglednica 47: Regresijski koeficienti za IT-spremembe

I87 Preglednica 48: Pojasnjenost regresijskega modela za IP-spremembe

I87 Preglednica 49: ANOVA za IP-spremembe

I88 Preglednica 50: Regresijski koeficienti za IP-spremembe

I88 Preglednica 51: Pojasnjenost regresijskega modela za RP-spremembe

189 Preglednica 52: ANOVA za RP-spremembe

189 Preglednica 53: Regresijski koeficienti za RP-spremembe

190 Preglednica 54: Pojasnjenost regresijskega modela za RT-spremembe

190 Preglednica 55: ANOVA za RT-spremembe

19I Preglednica 56: Regresijski koeficienti za RT-spremembe

I9I Preglednica 57: Pojasnjenost regresijskega modela za uspešnost sprememb

192 Preglednica 58: ANOVA za uspešnost sprememb

192 Preglednica 59: Regresijski koeficienti za uspešnost sprememb

193 Preglednica 60: Korelacijski koeficienti med konstrukti uspešnosti in vodenja

195 Preglednica 6r: Korelacijski koeficienti med konstrukti vodenja in sprememb 


\section{Krajšave}

IP

IT

LF-vodenje

RP

RT

MLQ - $5 \mathrm{X}$

TF-vodenje

TS-vodenje

Ur. 1. RS

ZUJF

ZZZS inkrementalno periferna

inkrementalno temeljna

vodenje laissez-faire

radikalno periferna

radikalno temeljna

Multifactor Leadership Questionnaire, verzija 5 X

transformacijsko vodenje

transakcijsko vodenje

Uradni list Republike Slovenije

»Zakon za uravnoteženje javnih financ«

Zavod za zdravstveno zavarovanje Slovenije 



\section{Uvod}

Zagotovo lahko trdimo, da so spremembe edina stalnica, ki je prisotna skozi vso človeško zgodovino. Današnji čas ni nobena izjema, le da živimo v dinamičnem globalnem okolju na začetku 2 I. stoletja, ki ga je zaznamovala globalna ekonomsko-finančna kriza. Globalizacijski procesi so poleg priložnosti sprožili tudi množico problemov. Prvenstveno konkurenčna naravnanost Evropske unije poraja zahteve po odlični kakovosti proizvodov in storitev, za kar sta potrebna ustvarjalnost zaposlenih ter njihovo vseživljenjsko učenje. Spremembe so gonilo organizacijskega razvoja in napredka, četudi se velikokrat odvijajo s tempom, ki je hitrejši od zmožnosti sledenja in prilagajanja organizacij. Organizacije so pod pritiskom, da se morajo hitro in pravilno odločati, poleg tega pa še preučiti dolgoročne vplive teh odločitev (Evans in Russell 1992, 21). Čeprav je sprememba lahko tudi spodbudna, pa negotovost, ki jo prinaša, povzroča nemalo skrbi. Organizacije največkrat skrbita njihovo dolgoročno preživetje in obstoj, posameznike pa ohranitev zaposlitve, položaja ali statusa.

Organizacije se spreminjajo vsak dan. Uspešno uvajanje sprememb pa je glavno vprašanje v vseh organizacijah, še posebej v času ekonomske krize (Al-Haddad in Kotnour 2015, 235). Avtorja (prav tam) se sprašujeta, kako naj organizacije posamezno vrsto spremembe uvajajo z najprimernejšo metodo in predlagata integracijo oz. uporabo večjega števila metod, ki lahko pokrijejo različne situacije $\mathrm{v}$ procesih spreminjanja.

Večina sprememb se dogaja postopno in nenačrtovano, nekako samoumevno, kot posledica spreminjajočega se okolja in želje posameznikov po nenehnem samopreseganju. Velike spremembe pa so običajno načrtovane in njihovo uvajanje in obvladovanje managerjem predstavlja eno 
težjih opravil, saj so lahko spremembe za zaposlene zelo stresne. Uvedba novih tehnologij, programov, politik ter procesov, spremembe pri osebju in njihovih vlogah znotraj organizacije, ljudi potisnejo iz znanih v nepoznana območja. Zato je določena stopnja odpora proti spremembam normalna in lahko vedno pričakovana. Večje odpore je pričakovati takrat, ko zaposleni spremembe zaznavajo kot grožnjo svojim temeljnim vrednotam in praksam ter $\mathrm{v}$ primerih, ko imajo spremembe negativen vpliv na posameznike (Pennington 2003, 7). Management sprememb zahteva odlične veščine managerjev v odločanju in strateškem načrtovanju (Hockin 2007, 49). Sprememba nikoli ni preprosta, zato Jones idr. (2008, 295) menijo, da je $\mathrm{v}$ procesu organizacijskega spreminjanja kritično prav vedenje vodij, ki postavljajo vizijo spremembe, zaposlenim nudijo potrebno podporo in predstavljajo primeren model vedenja.

Tudi v bolnišnicah so spremembe neizogibne in so sestavni del organizacijskega življenja. Nujno je zmanjševanje vseh vrst stroškov ob nespremenjeni oz. celo izboljšani kakovosti storitev. Razvijati stroko, slediti pričakovanjem uporabnikov in širše družbe, zmanjševati stroške in uvajati nove tehnologije za zdravstveni management ni lahko delo. Strinjamo se z Bukovcem (2009, 23), ki trdi, da je področje obvladovanja sprememb nesporno ena temeljnih konstant dela managerjev v organizacijah. Predpogoj za managersko obvladovanje sprememb pa je dobro razumevanje procesov spreminjanja. Teorija ponuja mnogo procesnih (faznih) modelov nadzorovanja sprememb, pa vendarle študije kažejo, da je vsaj 70 odstotkov uvajanj velikih sprememb v organizacijah neuspešnih (Mauer 2011a, 17; Werkman 2009, 664). Nekateri avtorji (npr. Michel, Todnem By in Burnes 2013, 763) neuspeh pri uvajanju sprememb pripisujejo predvsem psihološkim lastnostim zaposlenih, ki so nekako »predispozicionirani« na odpor proti kakršnikoli novosti, ne pa organizacijskim dejavnikom (strukture, sistemi, procesi idr.), drugi avtorji (Bennis in Nanus 2005, 172; Longenecker in Longenecker 2014, 152; Betbeze 2015, 39) pa vidijo razloge na strani vodij, med ostalim $\mathrm{v}$ njihovi premalo odprti oz. učinkoviti komunikaciji z zaposlenimi glede pomena in namena uvajanja sprememb. Po našem mnenju so za uspešnost managementa sprememb ključnega pomena elementi vodenja, ki se odražajo v odnosu in vplivu na zaposlene.

Sodobne organizacije želijo biti uspešne. Svoje napore usmerjajo v stalno rast in razvoj. Bukovec $(2009,17)$ težnjo po uspešnosti organizacij vzporeja z naravnimi zakoni, ki so usmerjeni v nenehno samopreseganje. Dolgoročno preživetje organizacij zahteva njihovo pravočasno prilagajanje na spreminjajoče se okolje. Čeprav so organizacijske spremembe stare 
toliko kot organizacije same, pa velja poudariti, da so današnje spremembe vse kompleksnejše.

Prožilci sprememb v organizacijah se nahajajo znotraj njih samih ali pa prihajajo iz zunanjega okolja. Harigopal (2006, 35-42) med zunanje razloge uvršča politične, tehnološke, ekonomske, vladne ter globalno tekmovanje, med notranje pa neustreznost obstoječih procesov, struktur, tehnologij, postopkov idr. Po Biloslavu $(2006,342)$ se razlogi v zunanjem okolju nahajajo v spreminjajočih se interesih različnih udeležencev, ki jih ločuje na udeležence tržnega okolja (odjemalci, dobavitelji, konkurenti), družbenega okolja (država, politika, združbe, javnost, gospodarstvo) ter kulturnega okolja (vrednote, navade, vzorniki, neformalna razmerja). Kot notranje razloge pa avtor (prav tam) navaja potrebe ljudi v organizaciji, ustvarjanje novega znanja in spreminjanje prevladujočih vrednot zaposlenih. Po Kovaču, Mühlbacherju in Kodyeku (20I2, I8) izhajajo zunanji razlogi iz makro in mikro trendov $\mathrm{v}$ okolju, ki jih mora manager prepoznati in razumeti, notranji razlogi pa iz zahtev lastnikov o nadaljnjem razvoju organizacije, viziji, strategiji in razvojni usmeritvi vodstva ter predlogov zaposlenih. Povzročitelji sprememb so po Patonu in McCalmanu (2000, 9): tehnološki napredek, spremenjena pričakovanja in potrebe strank, spremenjeni tržni pogoji, spreminjanje zakonodaje, spremembe družbenih vrednot idr. Doppler in Lauterburg (2008, v Kovač, Mühlbacher in Kodyek 20I2, I2) navajata družbene trende in izzive, ki organizacije silijo v stalna prilagajanja in spremembe:

- Revolucionarne spremembe $\mathrm{v}$ informatiki in telekomunikaciji: izdelki imajo vedno krajše življenjske cikle in temeljito spreminjajo načine ter oblike poslovanja in organiziranost.

- Pomanjkanje časa: posledica znanstveno-tehnološkega napredka je skrajševanje poslovnih procesov in življenjskih ciklov izdelkov in storitev, kar pospešeno poraja zahteve po razvoju novih izdelkov oz. storitev.

- Pomanjkanje denarja: razvita gospodarska okolja se soočajo z zviševanjem življenjskih stroškov, številčnim zniževanjem članov srednjega razreda ter upadanjem kupne moči, kar poraja ključne razvojne dileme, kako ohranjati zdržnost socialne države.

- Spremembe svetovnega trga: globalizacija organizacijam ne omogoča samo lažje dostopnosti do svetovnega trga, temveč istočasno zaostruje konkurenčnost. 
Caldwell, Butler in Poston (2010,4) na podlagi raziskave, v kateri so zajeli 525 vodilnih zdravstvenih managerjev, poročajo o treh najpomembnejših izzivih zdravstva: finančnem (zniževanje stroškov), nujnosti uvajanja zdravstvenih reform in skrbi za nezavarovane državljane. Goodwin $(2006,66)$ obravnava evropske perspektive zdravstva in izzive zdravstvenih managerjev, ki zahtevajo večje spremembe, razširja na:

- potrebe po večji učinkovitosti, produktivnosti in nadzoru nad stroški,

- naraščajoče zahteve po zdravstveni oskrbi kot posledice staranja prebivalstva in izboljševanja medicinske tehnologije ter farmacije,

- potrebo po snovanju učinkovitih in trajnostnih odgovorov zaradi naraščajočih zahtev uporabnikov po večji izbiri in boljšem ter hitrejšem dostopu do zdravstvenih storitev in naraščajočega števila gibanj v zvezi s pacientovimi pravicami,

- potreba po obvladovanju kroničnih bolezni (diabetes, kardiovaskularne bolezni, debelost idr.), nastalih zaradi sprememb v življenjskem stilu prebivalstva ter okoljskih sprememb.

Zavod za zdravstveno zavarovanje Slovenije (2014, 75-77) v svojem »Strateškem razvojnem programu 2014-2019《 navaja, da se bo slovensko zdravstvo, podobno kot $\mathrm{v}$ vseh državah EU, soočalo predvsem $\mathrm{z}$ naraščajočimi zahtevami po kakovostnih zdravstvenih storitvah kot posledici demografskih dejavnikov (staranje prebivalstva in demografska struktura prebivalstva, zdravstveno stanje prebivalstva) ter nedemografskih dejavnikov (nove medicinske tehnologije, zaposlenost $\mathrm{v}$ zdravstvu idr.), ki vplivajo predvsem na večjo ponudbo zdravstvenih storitev. Posledici demografskih dejavnikov sta najmanj dve. Prva se kaže v zmanjševanju prihodkov za zdravstvo zaradi zmanjševanja aktivne populacije, druga pa v povečevanju odhodkov zaradi večjega števila starejše populacije in spremenjenih potreb glede uveljavljanja zdravstvenih storitev. Vse našteto odpira mnoga razvojna vprašanja, ki so povezana s spremembami v zdravstvu in se nanašajo na pomembne dejavnike, kot so: prihodnja organizacija zdravstva, tehnologije zdravljenja, načini uveljavljanja storitev idr.

Tudi Ministrstvo za zdravje (2016b) v svoji $\gg$ Resoluciji o nacionalnem planu zdravstvenega varstva 2016-2015 « ugotavlja, da se v Sloveniji prav tako kot $\mathrm{v}$ drugih državah članicah EU in širše soočamo z mnogimi globalnimi izzivi, ki bodo odločilno vplivali na zdravstvene politike v prihodnosti: 
- naraščanje bremena kroničnih bolezni in stanj ter tistih, ki so odvisni od tuje pomoči,

- povečevanje neenakosti v zdravju,

- grožnje zdravju, ki jih predstavljajo nove nalezljive bolezni, odpornost mikrobov na zdravila in agensi iz okolja,

- finančna vzdržnost zdravstvenih sistemov,

- mobilnost pacientov.

Čeprav je bil v zadnjih desetletjih politični, tehnološki in ekonomski razvoj zelo dramatičen, pa je najpomembnejša sprememba, ki se je zgodila, prav hitrost spreminjanja samega. Spremembe se pojavljajo neprestano in vse hitreje in na to turbulenco se je treba navaditi kot na nekaj povsem običajnega (Branden 2000, I07). V organizacijah se spreminjata tako obseg kot vsebina njihovega delovanja. Prilagajanje na spremembe je postalo nujnost in nič več samo prednost, četudi drži dejstvo, da jih je zaradi njihove neverjetne dinamike težko obvladovati. Pred managerji so vse večji izzivi. Od njih se pričakuje, da so kos novim nalogam, ki jih poraja vse kompleksnejše okolje. Sodobne organizacije se torej soočajo z različnimi (tudi nujnimi) spremembami, vendar se dogaja, da je včasih inercija organizacijskih sistemov premočna, da bi spremembe uspešno implementirali oz. proces spreminjanja učinkovito obvladovali. Vodenje kot uspešno obvladovanje sprememb postaja eden izmed ključnih pogledov na vodenje.

Zaradi ekonomskih težav, v katerih se je znašla Slovenija v preteklih letih, postajajo spremembe $\mathrm{v}$ slovenskem zdravstvu konstanten proces, nujnost, ki je ni možno spregledati. Poleg zmanjšanega financiranja zdravstvenega sistema (kot posledica ekonomske in finančne krize) so se začeli spreminjati tudi odnosi na ravni pacient - zdravnik (včasih tudi druga vključena zdravstvena oseba), kajti informacije postajajo pacientom razpoložljivejše in transparentnejše. O boleznih in postopkih zdravljenja lahko vsakdo bere na svetovnem spletu. Priča smo prizadevanjem za razvoj varnega, učinkovitega in zanesljivega zdravstvenega sistema, ki pa je moral omenjene prednosti ohranjati ob proračunskem zniževanju sredstev ter ostalih vladnih ukrepih, kot je npr. zahteva po zmanjševanju števila zaposlenih v celotnem javnem sektorju. Spremembe v optimizaciji procesov (potekov) dela, novih strukturah organiziranosti, novih tehnologijah, novih metodah in postopkih zdravljenja, novih informacijskih rešitvah, stalnih prizadevanjih za boljšo kakovost zdravstvenih storitev ter uvajanju novih projektov, financiranih iz tržne dejavnosti, lahko potekajo le z dobrim managementom sprememb. V slovenskem zdravstvenem sistemu, ki sodi v javni nepridobitni sektor, postaja vodenje vse pomembnejše. Tavčar in Trunk Širca (1998, 80) navajata, da so med drugim raz- 
logi za to $\mathrm{v}$ participativnih odnosih in raznolikosti navzkrižnih interesov udeležencev v nepridobitnih organizacijah. Podobno v svojem predlogu $\gg$ Resolucije o nacionalnem planu zdravstvenega varstva 2016-2025 « ugotavlja tudi Ministrstvo za zdravje, saj navaja, da se v sistemu zdravstvenega varstva prepleta delo številnih deležnikov, katerih vloge pa včasih niso dovolj jasno opredeljene. Resolucija (Ministrstvo za zdravje 2016b) nadalje navaja, da $\gg$ vodenje, upravljanje in nadzor $v$ javnih $z$ dravstvenih zavodih ni ustrezno urejeno « in ga je nujno optimizirati, med drugim tudi z zaostrenimi pogoji glede zahtev po strokovnosti in izkušenosti vodstvenih kadrov.

V Sloveniji je 26 javnih bolnišnic, katerih ustanoviteljica je država. Država kot lastnica bolnišnic je odgovorna za regulacijo dejavnosti, ki se izvaja kot javna služba. Bolnišnice se financirajo skladno $s \gg$ Splošnim dogovorom « za posamezno poslovno leto. Splošni dogovor se oblikuje na podlagi partnerskih pogajanj med relevantnimi partnerji. Ti so: Ministrstvo za zdravje, Zavod za zdravstveno zavarovanje Slovenije (ZZZS), Združenje zdravstvenih zavodov, Skupnost socialnih zavodov, Skupnost slovenskih naravnih zdravilišč, Lekarniška zbornica in Zdravniška zbornica. V omenjenem »Splošnem dogovoru « partnerji dogovorijo količino in vrednost zdravstvenih storitev ter njihovo razporeditev. Iz $\gg$ Poročila o poslovanju javnih zdravstvenih zavodov za leto $2015 \ll$, ki ga je pripravilo Ministrstvo za zdravje (2or6a, 8), je razvidno, da so od 26 javnih bolnišnic $s$ tekočim primanjkljajem poslovale 3 bolnišnice. Pregled poslovnih izidov bolnišnic v daljšem, 3-letnem obdobju 2013-2015 pa pokaže, da je $s$ tekočim primanjkljajem vsaj v enem letu analiziranega obdobja poslovalo kar I 8 bolnišnic

Večina bolnišnic skrbi za sisteme vodenja kakovosti in imajo uvedene modele - lahko jih imenujemo modeli za obvladovanje sprememb (npr. ISO-standardi), velika večina jih je tudi mednarodno akreditirana na podlagi mednarodno priznanih zdravstvenih standardov, kot so:

- DIAS - DNV (International Accreditation Standard for Hospitals),

- AACI (International Accreditation Standards for Healthcare Organizations),

- JCI (Joint Commission International).

$\mathrm{Na}$ nacionalnem nivoju pa ne obstajajo neka skupna merila oz. lestvice, na podlagi katerih bi lahko celoviteje vrednotili zdravstvene organizacije po enotnem sistemu. 
Stalna skrb za obvladovanje stroškov in poslovno učinkovitost bolnišnic, zahteve in pričakovanja po stalnem dvigu kakovosti zdravstvenih storitev, pomanjkanje nekaterih ključnih kadrov, vse večja informatizacija poslovanja ter spreminajoča se zakonodaja so ključni dejavniki, ki sprožajo procese spreminjanja v slovenskih bolnišnicah. Skela Savič (2008, II) pravi, da bolnišnice na novosti $v$ tehnologiji niso reagirale $s$ takšno hitrostjo in fleksibilnostjo, kot je to izvedla druga industrija. Skela Savič $(2008,2 \mathrm{I})$ ugotavlja, da so zdravstveni vodje hierarhično usmerjeni in izvajajo direktivno vodenje, kar ne olajšuje procesov spreminjanja. Uspešnost sprememb je odvisna od uspešnega vodenja in obvladovanja procesov spreminjanja ter pravočasne implementacije sprememb. Nesposobnost vodenja procesov spreminjanja lahko povzroči neuspešnost bolnišnice, kar seveda ne vodi nujno $\mathrm{v}$ njen propad, lahko pa se posledično odraža v slabši kakovosti storitev za paciente in slabši kakovosti odnosov med zaposlenimi, kar ponovno vpliva na slabše izvedeno delo, ki še poslabša kakovost storitev - in začarani krog je sklenjen.

Prihodnosti organizacij ni mogoče napovedati, ampak jo je, kot menita Nordström in Ridderstråle (200I, 35), potrebno ustvarjati. Znašli smo se $\mathrm{v}$ svetu kaosa ter negotovosti in prilagajanje na spremembe je stalna praksa. Prilagajanje na spremembe pa je proaktiven in dinamičen proces, pri katerem je ključnega pomena uporaba intelektualnega potenciala vseh sodelavcev ob predhodni skrbi za razvoj zaposlenih. Zdravstvena organizacija je lahko proaktivna in sama daje pobude v zvezi s spremembami - takšna je praviloma tudi uspešnejša - ali pa je reaktivna in se na pobude zgolj odziva.

V pričujoči monografiji nas bodo zanimali proaktivni pristopi pri izvajanju sprememb v bolnišnicah. Carnall $(2007,63)$ navaja, da se načini vodenja sprememb razlikujejo glede na vrsto spremembe, ki se uvaja v organizaciji. Mnogo sprememb je obsojenih na propad in po izkušnjah Smitha ter Mourierja $(1999,38)$ jih večina pade v fazi implementacije, bodisi zaradi odporov zaposlenih bodisi zaradi nemoči ali neusposobljenosti managerjev, ki bi z ustreznim načinom vodenja lahko dosegli večji delež uvedenih sprememb. Vodje v zdravstvu gradijo vodenje predvsem na svojem poklicnem znanju (Skela Savič 2008, I4). Podobno ugotavlja tudi Gračner (2014, 230), ki pravi, da močno izražena poklicna kultura zdravnikov negativno vpliva na njihovo sprejemanje sprememb. Tudi Branagan (20IO, II) izpostavlja močne zdravniške odpore pri poskusu uvedbe IT-sistemov, ki so se razplamteli celo do groženj s stavko. 
Tisti, ki vodijo spremembe $\mathrm{v}$ bolnišnicah, običajno ne razpolagajo z znanji vodenja oz. managementa sprememb. Skela Savič (2008, I5) poudarja, da »je koncept managementa $v$ slovenskem $z$ dravstvu se vedno povezan s prepričanjem, da zdravnik z medicinsko fakulteto obvlada tudi managersko delo«. Shortell, Zazzali in Burns (200I, v Skela Savič 2008, I5) navajajo razsežnosti sodobnega vodenja kot enega izmed dejavnikov uspešnega spreminjanja zdravstvenih organizacij:

- $\quad$ vzpostavitev situacijskega vodenja;

- nujnost prehoda iz transakcijskega $\mathrm{v}$ transformacijsko vodenje;

- spreminjanje ne sme temeljiti samo na karizmatičnem vodenju, ker različne skupine pričakujejo različne stile vodenja, zato potrebujemo vodje z znanji vodenja;

- vodja $\mathrm{v}$ zdravstvu mora imeti znanja in veščine s področja komunikacije in povezovanja ljudi in ciljev, sposobnosti oblikovanja skupne vizije, sposobnosti izvrševanja idr.;

- potrebni so programi za izobraževanje vodij, ki morajo biti skupni za vse poklicne skupine;

- učinkovito vodenje je orodje za implementacijo sistema kakovosti.

Ugotavljamo, da spremembe, ki so vezane na razvoj stroke oz. zdravljenja in diagnostike, zaposlenim $\mathrm{v}$ zdravstvenih poklicih pri implementaciji ne delajo tolikšnih težav kot druge vrste sprememb (npr. organizacijske spremembe ali uvajanje novih informacijskih sistemov ipd.). $\mathrm{V}$ slovenskem zdravstvu so spremembe nujne. $\mathrm{V}$ pretežnem delu management slovenskih bolnišnic ni vešč uporabe ustreznih načinov vodenja niti ne ve, kakšni bi ti pristopi morali biti. Na to kažejo mnogi pokazatelji: negativno poslovanje bolnišnic, različne afere, močno izraženi konflikti, obračunavanja $v$ medijih, odhajanje strokovnih kadrov v tujino ipd. Tudi »Poročilo o primerjalnem merjenju organizacijske klime v bolnišnicah « (OCR - SiOK 2016, I4-15) kaže na trende poslabševanja v kategorijah, ki se nanašajo na vodenje, komunikacijo in notranje odnose. Nekateri tuji avtorji (Mosadegh Rad in Yarmohammadian 2014, 23) prav tako ugotavljajo, da ima zdravstveni management nezadostno znanje o principih in teorijah vodenja. Ministrstvo za zdravje (2016a; 2016b) za slovenski zdravstveni sistem ugotavlja, da vodenje $v$ javnih zdravstvenih zavodih ni ustrezno urejeno. Poslovodstva nimajo dovolj pooblastil in orodij za vodenje. Tudi organi upravljanja (sveti zavodov) zaradi pomanjkanja kompetenc marsikje ne opravijo svoje vloge. 
Raziskovalci so $\mathrm{v}$ dosedanjih raziskavah poskušali dognati, kateri dejavniki najbolj vplivajo na uspešno izvajanje sprememb v zdravstvenih organizacijah. Skela Savič in Pagon $(2007,69)$ v svoji raziskavi ugotavljata, da je timsko delo ključni dejavnik, Ferlie in Shortell (v Skela Savič in Pagon 2007, 72) pa kot ključne navajata: vodenje na vseh nivojih, učečo se kulturo, razvoj timov in informacijsko podporo procesom spreminjanja. Hockin $(2007,86)$ v svoji raziskavi med drugim ugotavlja, da so za uspešen management sprememb v zdravstvu pomembne naslednje aktivnosti vodij: strateško planiranje, etičnost, sprejemanje odločitev in komunikacija. Hernandez (2010) je preučeval povezanost stilov vodenja z uspešnostjo bolnišnic, pri čemer je uspešnost definiral kot zmožnost bolnišnic, da dosegajo in vzdržujejo postavljena merila odličnosti (Top ıoo Hospitals). Ugotovil je (Hernandez 2010, 90), da v uspešnih bolnišnicah pri vršnih managerjih prevladuje transformacijsko vodenje, pri čemer kot dimenzije omenjenega stila vodenja najbolj izstopajo individualna obravnava zaposlenih, učinkovitost, navdihujoče motiviranje in intelektualno stimuliranje.

Mnogi avtorji (Dubrin 2004, 68; Northouse 2001, 131; Tichy in Devanna I990, 6) uvajanje sprememb povezujejo $s$ transformacijskim stilom vodenja. Transformacijski vodja zaposlene navdihuje $\mathrm{z}$ vizijo in $\mathrm{s}$ skupnimi cilji, zanj je pomemben posameznik, ki ga vodja vzpodbuja in intelektualno stimulira, $s$ tem pa odpira prosto pot ustvarjalnosti in inovativnosti, ki sta pogoj za uspešno uvajanje sprememb (Dessler 200I, 8I). O pozitivnem vplivu transformacijskega vodenja na organizacijsko inovativnost pričajo tudi rezultati raziskave, ki so jo opravili Mokhber, Wan Ismail in Vakilbashi (2015, 233). Avtorji (prav tam, 235) ugotavljajo, da je med široko paleto raziskav o vodenju transformacijski vodja prepoznan kot spretnejši v podpiranju vrednot in norm pri zaposlenih ter pri pospeševanju organizacijskih in osebnih sprememb. Prav tako transformacijski način vodenja izboljšuje medosebno komunikacijo med vodjo in zaposlenimi (Bennett 1997, 187). Kot nasprotje transformacijskemu načinu se pojavlja transakcijsko vodenje, ki mu Bass (1990, 190) pripisuje naslednje dimenzije: pogojevano nagrajevanje, management $\mathrm{z}$ izjemami (pasivni), management $\mathrm{z}$ izjemami (aktivni) ter vodenje laissez-faire Transakcijski vodja ne navdušuje, prepozna sicer potrebe zaposlenih in jim za doseganje rezultatov ponuja različne nagrade ter privilegije. Vodenje laissez-faire (vodenje brez vajeti) je pasivni stil vodenja, pri katerem se vodja odreče svoji odgovornosti, s tem da podrejenim dovoli visoko stopnjo neodvisnosti in svobode. Izogiba se sprejemanju odločitev in ne daje ključnih smer- 
nic, ko so potrebne. Je pa ta stil lahko učinkovit pri visoko usposobljenih in motiviranih zaposlenih, kot so npr. eksperti v zdravstvenem timu.

Predmet preučevanja $\mathrm{v}$ pričujoči monografiji sodi na področje vodenja sprememb v bolnišnicah, ki je v slovenskem prostoru še dokaj neraziskano. Našli smo nekaj raziskav, ki se deloma dotikajo omenjenega področja. Skela Savič in Pagon $(2007,65)$ sta raziskovala dejavnike uspešnega izvajanja sprememb v slovenskih bolnišnicah, pri čemer sta prisotnost transformacijskega, transakcijskega in vodenja laissez-faire ugotavljala $s$ Kouzes-Posnerjevim instrumentom, Leadership Practices Inventory, na osnovi enajstih trditev. Avtorja (Skela Savič in Pagon 2007, 69) sta ugotovila, da vodje $\mathrm{v}$ zdravstvu v pretežnem delu izvajajo direktivno vodenje, zaposlene le seznanjajo, v odločanje pa jih ne vključujejo, kar predstavlja slabo popotnico za uspešno izvajanje sprememb.

Gračner (2014) je v svoji kvalitativni raziskavi ugotavljala dejavnike, ki vplivajo na pripravljenost zdravnikov na uvajanje kulture varnosti bolnikov. Avtorica (Gračner, 2014) je ugotovila, da je pri zdravnikih močno izražena poklicna kultura, ki se je dolga leta utrjevala skozi njihovo učenje in prakso. In prav ta močna poklicna kultura negativno vpliva na pripravljenost zdravnikov na uvajanje sprememb.

Robida, Skela Savič in Trunk (2008) so raziskovali kompetentnost srednjega managementa $\mathrm{v}$ zdravstvu na področju managementa in vodenja. Avtorji (prav tam) so prepričani, da je v zdravstvu izrednega pomena obvladovanje konceptov in tehnik sodobnega managementa, hkrati pa ugotavljajo pomanjkljivo delovanje vodij pri reševanju vsakodnevnih delovnih problemov in pri dajanju jasnih povratnih informacij $\mathrm{v}$ zvezi $\mathrm{z}$ delom zaposlenih.

Bola Natek (2014) pa je raziskovala kompetence za vodenje pri zdravnikih in njihov vpliv na uvajanje sodobnih, horizontalnih oblik organiziranosti. Ugotovila je (Bola Natek 20I4), da slovenskim managerjem primanjkuje predvsem t. i. »mehkih « kompetenc, kar se odraža v njihovih težavah $s$ timskim delom, težavah $\mathrm{v}$ komunikaciji, iskanju krivcev, zadrževanju pooblastil, nesposobnosti motiviranja zaposlenih idr.

Management sprememb je eno najbolj raziskanih področij v managementu, ni pa to področje podrobno raziskano na primeru zdravstvenih organizacij, še posebej ne $\mathrm{v}$ Sloveniji. $Z$ raziskavo smo želeli prispevati $\mathrm{k}$ dopolnitvi znanja o managementu sprememb v bolnišnicah in doseči predvsem dvoje:

- razviti načine za učinkovito vodenje sprememb v slovenskih bolnišnicah, ki bodo vodjem omogočali, da bodo pri izvajanju posameznih korakov $\mathrm{v}$ procesih spreminjanja suverenejši; ugo- 
tavljali smo, kako so se $\mathrm{v}$ bolnišnicah lotevali posameznih vrst sprememb, da bi te bile uspešno implementirane;

- ugotavljati in preučiti pristope in stile vodenja, ki so v bolnišnicah najbolj povezani s procesi spreminjanja; določili smo stile vodenja, ki jih povezujemo z različnimi vrstami sprememb.

Empirična raziskava daje odgovore na mnoga vprašanja:

- Kako management v bolnišnicah vodi procese spreminjanja?

- Katere vrste sprememb izvajajo v slovenskih bolnišnicah?

- Kakšne vodstvene pristope uporablja management za izvajanje posameznih vrst sprememb?

- Kateri stili vodenja se povezujejo z uspešnostjo izvajanja sprememb?

$\mathrm{Na}$ podlagi preučevanja literature in izsledkov tujih in domačih raziskav ter naše empirične raziskave smo želeli potrditi domnevo, da obstaja povezanost vodenja $\mathrm{z}$ uspešnostjo procesa izvajanja sprememb v slovenskih bolnišnicah. Pri tem smo se osredotočili na Penningtonovo (2003, 6) kategorizacijo sprememb, ki slednje deli na:

- radikalno temeljne ( $R T)$, ki predstavljajo korenito spremembo temeljnih dejavnosti (npr. sprememba strategije ali temeljnega programa bolnišnice oz. njene posamezne organizacijske enote);

- radikalno periferne $(R P)$, ki predstavljajo korenito spremembo obrobnih dejavnosti (zamenjava obrobnih programov, korenita sprememba obrobnih procesov);

- inkrementalno temeljne (IT), ki predstavljajo postopne spremembe temeljnih dejavnosti v smislu njihovega stalnega izboljševanja;

- inkrementalno periferne (IP), ki predstavljajo postopne spremembe obrobnih dejavnosti v smislu njihovega stalnega izboljševanja.

Monografija je namenjena tako teoretikom, ki želijo poglobiti védenje o preučevanem področju, kot tudi zdravstvenim managerjem oz. vodjem, ki želijo naša dognanja uporabljati pri svoji vodstveni praksi. Rezultati empirične raziskave bralcu ponujajo širok okvir spoznanj in razumevanj o:

- procesih spreminjanja v slovenskih bolnišnicah;

- različnih vrstah sprememb v bolnišnicah;

- značilnih stilih vodenja sprememb;

- povezanosti stilov vodenja z izvajanjem različnih vrst sprememb; 
- povezanosti stilov vodenja z zaznano uspešnostjo uvedenih sprememb;

- predlagani zasnovi modela uspešnega vodenja sprememb v slovenskih bolnišnicah.

Naša temeljna domneva $\mathrm{v}$ raziskavi je bila, da je uspešnost procesa izvajanja sprememb povezana s stilom vodenja in njegovimi komponentami oz. dimenzijami. Na osnovi teoretičnih ugotovitev in izsledkov dotedanjih raziskav smo predpostavljali, da zdravstveni manager oz. vodja pri različnih vrstah sprememb uporablja različne vodstvene pristope, pri čemer smo izvajanje radikalno temeljne spremembe povezovali s transformacijskim vodenjem, ostale tri spremembe pa s transakcijskim vodenjem. Postavili smo naslednje hipoteze:

$\mathrm{H}_{\mathrm{I}}$ : Transformacijsko vodenje je pozitivno povezano z zaznano (ocenjeno) uspešnostjo uvedenih sprememb.

$\mathrm{H}_{2}$ : Transakcijsko vodenje je prav tako pozitivno povezano z zaznano uspešnostjo uvedenih sprememb, vendar v manjši meri kot transformacijsko vodenje.

$\mathrm{H}_{3}$ : Vodenje laissez-faire je negativno povezano z zaznano uspešnostjo uvedenih sprememb.

$\mathrm{H}_{4}$ : Transakcijsko vodenje je pozitivno povezano z IT-, IP- ter s RP-spremembo.

$\mathrm{H}_{5}$ : Transformacijsko vodenje je pozitivno povezano z IT-, IP- ter s RP-spremembo, vendar v manjšem obsegu kot transakcijsko vodenje.

H6: Transakcijsko vodenje je pozitivno povezano z RT-spremembo, vendar v manjšem obsegu kot transformacijsko vodenje.

$\mathrm{H}_{7}$ : Vodenje laissez-faire je negativno povezano z vsemi štirimi vrstami sprememb.

Izvedli smo kombinirano raziskavo, ki je vključevala uporabo kvalitativnih in kvantitativnih metod raziskovalnega dela. $\mathrm{V}$ kvalitativnem delu se je raziskava osredotočala na preučevanje procesov spreminjanja $\mathrm{v}$ slovenskih bolnišnicah. Ugotavljali smo, kako so se v posameznih bolnišnicah lotevali korenitih oz. velikih sprememb svojih temeljnih in/ali perifernih dejavnosti. Ugotavljali smo tudi, kako so se postopno oz. po metodi manjših korakov lotevali sprememb svojih temeljnih in/ali perifernih dejavnosti. V okviru preučevanja procesov spreminjanja nas je prvenstveno zanimalo, kakšna tveganja in motnje so spremembe predstavljale v obstoječih delovnih procesih, kakšni odpori so se pojavljali in kako so se soočali z njimi. Kvalitativna raziskava je bila namenjena tudi 
začetnemu ugotavljanju vrste sprememb, ki so jih izvajali, in njihovemu razumevanju ter identificiranju najpomembnejših elementov vodenja $\mathrm{v}$ procesih spreminjanja.

Kvantitativni del raziskave je bil osredotočen na ugotavljanje statistične povezanosti med vrsto spremembe ter posameznimi stili vodenja. $\mathrm{V}$ tem delu smo merili tudi zaznano uspešnost (percepcijo uspešnosti) uvedenih oz. izvedenih sprememb.

Raziskava, povezana s stili vodenja za izvajanje sprememb, je prva tovrstna $\mathrm{v}$ slovenskih bolnišnicah. Razširja razumevanje povezanosti med transformacijskim, transakcijskim in stilom vodenja laissez-faire ter izvajanjem organizacijskih sprememb. Prinaša nova spoznanja o načinih vodenja različnih vrst sprememb v bolnišnicah (tj. RT-, RP-, IT- in IP-sprememb). Pri tem se ne osredotoča samo na omenjene glavne stile vodenja, temveč tudi na vse njihove ključne dimenzije. Kot takšna lahko predstavlja podlago za razvoj programov usposabljanja o vodstvenih kompetencah oz. služi kot osnova za vodstvene prakse ob izvajanju sprememb. Zasnova modela vodenja prispeva $\mathrm{k}$ razvoju teorije obravnavanega področja. Nova lestvica za merjenje vrst sprememb v bolnišnicah pa predstavlja uporaben pripomoček za ugotavljanje radikalnih in inkrementalnih sprememb tako v temeljnih kot tudi v podpornih procesih zdravstvene organizacije.

Empirična raziskava je bila zasnovana na mešanem kvalitativno kvantitativnem pristopu. Najprej je bilo opravljeno kvalitativno raziskovanje skladno s Sagadinovim pogledom (200I, I4), ki pravi, da nas poprejšnji kvalitativni pristop lahko pripelje do informacij, ki nam pomagajo pri snovanju kvantitativne raziskave. Drugi razlog je v tem, da je vodenje sprememb procesno naravnana aktivnost; za raziskovanje procesov pa so po trditvah mnogih avtorjev primernejše kvalitativne metode (Merriam 1998, 33; Flere 2000, 21; Alvesson in Deetz 2000, 60). V nadaljevanju smo uporabili metodo anketiranja. Populacijo za kvantitativno raziskavo so predstavljale slovenske bolnišnice ( $\mathrm{v}$ vseh 26 javnih bolnišnicah je približno 23.000 zaposlenih). Uporabljeno je bilo verjetnostno vzorčenje, pri čemer je bila naključno izbrana tretjina bolnišnic. Anketni vprašalnik je bil poslan približno 3.000 zaposlenim v izbranih bolnišnicah, pri čemer je bila upoštevana sorazmernost glede na število zaposlenih v posamezni bolnišnici in oddelkih znotraj bolnišnice.

V kvalitativnem raziskovanju rezultatov njihovega razumevanja ne moremo posploševati oz. prenašati na druga okolja, lahko pa poskrbimo, da se rezultati raziskave kar se da približajo objektivni stvarnosti. Zato smo poskrbeli, da smo veljavnost raziskave (Tratnik 2002, 4I) povečali s triangulacijo in zagotovili ( $\mathrm{I}$ ) tri vire podatkov znotraj bolnišnic (direk- 
torji in pomočniki direktorjev, vodje, zaposleni) in (2) vsaj tri metode zbiranja podatkov (analiza dokumentov, polstrukturiran intervju, fokusne skupine, anketa).

Anketni vprašalnik je bil sestavljen iz štirih delov. Prvi del vprašalnika je bil namenjen ugotavljanju vključenosti zaposlenih v spremembe ter vrste sprememb skladno s Penningtonovo kategorizacijo $(2003,6)$. Drugi del je bil namenjen ocenjevanju uspešnosti uvedenih sprememb, vezanih na roke, stroške in doseganje začrtanih ciljev. Tretji del je bil namenjen ugotavljanju razpona vodstvenih vedenj oz. stilov vodenja. $\mathrm{V}$ tem delu smo uporabili že mnogokrat uporabljen, zanesljiv in validiran Bassov instrument MLQ - 5 X (Multifactor Leadership Questionnaire), ki ga sestavlja 45 trditev. Za potrebe naše raziskave smo uporabili samo 36 trditev, ki merijo omenjene stile vodenja, nismo pa merili zadovoljstva, učinkovitosti in dodatnih prizadevanj zaposlenih v povezavi s stilom vodenja, ker $\mathrm{z}$ vidika naše raziskave niso bili relevantni. Anketiranci so se opredeljevali do trditev na lestvici Likertovega tipa. Bassov model zajema širok razpon vodstvenih stilov, pri čemer tri glavne stile (konstrukte) deli na več dimenzij oz. subkonstruktov, s katerimi lažje in natančneje pojasnimo opazovane pojave. Kot primeren instrument se nam zdi tudi zato, ker ne izključuje stilov vodenja v smislu ali-ali, temveč integrira, kar pomeni, da ima lahko vodja izražen tako transakcijski kot transformacijski stil vodenja. Četrti del vprašalnika pa je bil vezan na demografske podatke.

Stili vodenja z vsemi svojimi dimenzijami so nam predstavljali neodvisne spremenljivke, radikalno temeljne (RT), radikalno periferne (RP), inkrementalno temeljne (IT), inkrementalno periferne (IP) spremembe ter uspešnost oz. percepcija uspešnosti uvedene spremembe pa odvisne spremenljivke. Podatki so bili obdelani z računalniškim programom SPSS; uporabili smo metodo deskripcije in faktorsko analizo merjenih spremenljivk (ali posamezni indikatorji merijo omenjene spremenljivke oz. konstrukte). Odnose med merjenimi spremenljivkami smo ugotavljali s korelacijsko analizo. Z linearno regresijo pa smo preverili povezave med posameznimi konstrukti oz. eno odvisno in neodvisnimi spremenljivkami.

Analiza kvalitativnih podatkov je bila opravljena skladno s splošnim analitičnim postopkom po Milesu in Hubermanu (1994, 172-205), ki poudarja pomen prečne analize (angl. cross-case analysis) z namenom večjega posploševanja (generalizacije), ki pa ga kljub uporabi omenjenega postopka lahko v kvalitativnem delu omejimo zgolj na preučevane bolnišnice. Na vzorcu 24 fokusnih skupin (I3 I udeležencev) zbrani kvali- 
tativni podatki so zahtevali natančno in kritično refleksijo, $s$ katero smo oblikovali glavna področja odgovorov oz. kategorije.

V naslednjih poglavjih monografije predstavljamo teoretični sprehod po relevantni literaturi preučevanega področja. Izpostavimo predvsem komplementarnost procesov managementa in procesov vodenja, dotaknemo se osnovnih konceptov spreminjanja ter vrst sprememb, pojasnimo razloge za odpore in neuspeh pri uvajanju sprememb. Posebni poglavji smo namenili pomembnejšim teorijam in stilom vodenja ter značilnostim nekaterih modelov managementa sprememb. $\mathrm{Na}$ osnovi preučene literature smo izoblikovali konceptualni model in ga preverili v empirični raziskavi, katere rezultati so predstavljeni v sedmem poglavju monografije. 



\section{Vodenje in spreminjanje v zdravstvenih organizacijah}

$\mathrm{V}$ današnjih časih, ko je sprememba bolj pravilo kot izjema, postajata najpomembnejši zmožnosti organizacij njihova dovzetnost in odprtost za spremembe (Bouckenooghe, Devos in Van den Broeck 2009, 559). Uvajanje sprememb je ključni dejavnik razvoja zdravstvenih praks. Vitalnega pomena za uspešno uvedbo spremembe je njeno sprejemanje pri zaposlenih. Naj bo sprememba še tako dobro načrtovana $\mathrm{v}$ smislu jasnih in dosegljivih ciljev, sprejemljivih rokov in potrebnih virov (materialnih, finančnih, kadrovskih), je vedno treba preučiti njen človeški vidik (Hewitt-Taylor 2013, 36), predvsem, kaj bodo posamezniki in timi z njo pridobili ali izgubili, kateri zaposleni bodo lahko prispevali največ zamisli (bodo vodilni pri zamislih oz. t. i. »opinion makers «) ter kje in kakšne odpore pričakovati. Kot pravi Hewitt-Taylor (2013, 35), razlog za neuspeh spremembe $\mathrm{v}$ praksi ni v slabem načrtovanju, ampak predvsem $\mathrm{v}$ tem, da zaposleni ne spremenijo svojih načinov dela, kar kaže na dejstvo, da je uvedba sprememb še v večji meri odvisna od vodenja. To potrjujejo spoznanja mnogih avtorjev, ki so preučevali pristope $\mathrm{k}$ spremembam v kliničnih okoljih oz. zdravstvenih organizacijah (Alimo-Metcalfe in Alban-Metcalfe 2005, 62-67; Fagerstr囚m in Salmela 2010, 616; Siverbo, Eriksson in Wijk 2013, 165-66). Tan (2010) vodenje sprememb uvršča med zelo zahtevne naloge managerjev. Vodenje sprememb lahko po eni strani obravnavamo kot znanost, po drugi strani pa kot umetnost. Znanstvena opredelitev se opira na niz korakov, ki so lahko načrtovani in dokumentirani. Kljub dokumentiranemu procesu spreminjanja pa je ravno zmožnost slediti tem korakom precej individualne narave. Vsak vodja izbira svoje pristope in tehnike, ki so tesno povezani z njegovimi izkušnja- 
mi in percepcijami. Poleg tega je spreminjanje odvisno tudi od konteksta in okolja, v katerem sprememba poteka.

$\mathrm{V}$ tem poglavju bomo prikazali razmejitev procesov managementa in vodenja ter hkrati njuno neločljivo povezanost oz. prepletanje. Osredotočili se bomo na procese vodenja s poudarkom na vodenju sprememb v zdravstveni organizaciji. Seznanili se bomo z nekaterimi organizacijskimi koncepti spreminjanja in vrstami sprememb, kot jih opredeljujejo posamezni avtorji, spoznali primer preproste analize silnic (pospeševalcev in omejevalcev sprememb) ter pregledali najpomembnejše razloge za odpore pri spremembah in razloge za neuspeh pri uvajanju sprememb. Dotaknili se bomo tudi spreminjanja organizacijske kulture, ki jo največkrat povezujemo z uvajanjem radikalnih sprememb v organizacijah.

\section{Managemet in vodenje - komplementarnost dveh procesov}

Mnogi avtorji ugotavljajo, da je vodenje pomensko ožji pojem in predstavlja zgolj eno od štirih funkcij managementa, tj. načrtovanja, organiziranja, vodenja in nadziranja (Dubrin 2004, 4; Kovač, Mayer in Jesenko 2004, 17; Dessler 2001, 3; Tavčar 2000, 2; Yukl 1998, 5; Možina idr. ı996, I I). V literaturi pa lahko zasledimo poskuse razmejitev med managementom in vodenjem $\mathrm{z}$ različnimi poudarki, ki managementu pripisujejo organiziranost, implementacijo, kompleksnost ter usmeritev v sedanjost, vodenju pa vizijo, procese, spremembe in usmerjenost v prihodnost (Kovač, Mayer in Jesenko 2004, 19). Po Georgiadesu in Macdonellu (1998, I87) management nadzira in integrira aktivnosti znotraj organizacij, medtem ko voditeljstvo stimulira spreminjanje in inovativnost. Management je fenomen i9. stoletja oz. industrijske revolucije, ki se je v polni meri razvil kasneje, na začetku 20. stoletja. Njegov osnovni namen je obvladovati organizacijsko kompleksnost in dosegati stabilnost. Procesi, ki jih pripisujemo managementu, $v$ organizacijo vnašajo red in ustaljenost. Je formalnejši in bolj znanstven od vodenja (Goodwin 2006, 7; Dubrin 2004,4 ), saj uporablja preizkušena orodja in tehnike. Proces vodenja pa je na odnosu osnovan proces, ki ga razvijajo vodja in sledilci, $z$ medsebojnim vplivom drug na drugega (Goodwin 2006, 15; Northouse 200I, 3). Vodenje se torej nanaša na odnose (Kouzes in Posner 1987, 8), pri čemer velja poudariti, da gre za sposobnost vplivanja vodij na zaposlene, da se vedejo na želen oz. pričakovan način in dosegajo zastavljene cilje (Northouse 2001, 3; Yukl 1998, 3; Možina idr. 1996; 91). Strokovna literatura ponuja mnoge razprave o odnosu med managementom in vodenjem. Dubrin $(2004,5)$ ugotavlja ključne razlike med njima, ki so: 
- večja formalnost in znanstvenost managementa, ki gradi na veščinah, kot so: načrtovanje, skrb za proračun in nadziranje;

- vodenje vključuje vizijo o tem, kaj organizacija lahko postane, in $\mathrm{z}$ njo mobilizira zaposlene $\mathrm{k}$ doseganju vizije;

- vodenje povzroča spremembe, včasih zelo drastične, kot sta npr. nov proizvod oz. stori-tev ali nov trg za star proizvod oz. storitev;

- vodenje spodbuja sodelovanje in timsko delo široke mreže zaposlenih ter $\mathrm{z}$ različnimi načini prepričevanja ključne ljudi $\mathrm{v}$ tej mreži ohranja motivirane;

- vodje najvišjih nivojev transformirajo svoje organizacije, medtem ko managerji najvišjih nivojev organizacije zgolj vzdržujejo;

- vodje kreirajo vizijo, ki usmerja organizacijo, ključna funkcija managerja pa je to vizijo implementirati v prakso.

Primerjavo osnovnih aktivnosti managementa v primerjavi z vodenjem predstavlja Kotter (1990, v Northouse 200I, 9) in jo prikazuje slika I.

\begin{tabular}{|l|l|}
\hline \multicolumn{1}{|c|}{ MANAGEMENT } & \multicolumn{1}{c|}{ VODENJE } \\
Red in konsistentnost & \multicolumn{1}{c|}{ Sprememba in gibanje } \\
\hline - Načrtovanje/proračun & - Gradnja vizije/strategije \\
- Organiziranje/kadrovanje & - Usmerjanje ljudi/komuniciranje \\
- Nadziranje/reševanje problemov & - Motiviranje/navdihovanje \\
\hline
\end{tabular}

Slika I: Primerjava med managementom in vodenjem

Vir: Kotter 1990, v Northouse 200 I, 9.

Aktivnost načrtovanja in skrb za proračun pomeni postavljanje rokov ter alociranje potrebnih virov za doseganje organizacijskih ciljev. Organiziranje in kadrovanje vključuje postavitev strukture za delo posameznikov ter njihove povezave v organizaciji, kar pomeni postaviti ljudi na prava mesta ter razvijati pravila in procedure za njihovo delo. Aktivnost nadziranja za managerja pomeni osredotočanje na razvoj sistemov, s katerimi bo motiviral zaposlene, reševanje problemov pa zanj pomeni ugotavljanje napredovanja proti postavljenim ciljem in uvajanje določenih korektivnih ukrepov, kadar napredek ni v skladu z načrtovanim. Černetič (1997, 177) meni, da ima manager pomembno nalogo, saj mora oblikovati novo celoto, ki je večja od vsote svojih delov. Poleg standardnih štirih funkcij Černetič (1997, 179) managerju pripisuje še pomembno nalogo, tj. skrb za razvoj sodelavcev, vključujoč skrb za razvoj samega sebe. Za 
razliko od managerja pa vodja postavlja vizijo organizacije ter komunicira z zaposlenimi na način, da v njih vzbuja zavzetost in delovno vnemo, gradi time in različne koalicije, $s$ katerimi izpolnjuje poslanstvo organizacije. Pri tem zaposlenim nudi podporo, jih usmerja in omogoča opolnomočenje.

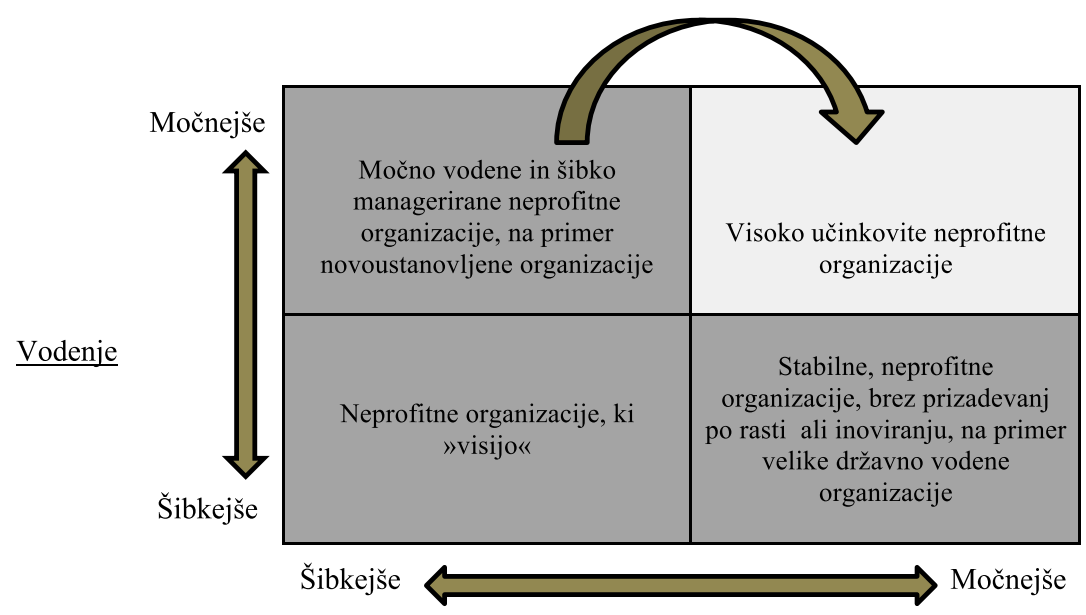

Management

Slika 2: Primerjava med managementom in vodenjem v neprofitnih organizacijah Vir: Stid in Bradach 2009, 36.

Stid in Bradach $(2009,35)$ sta ugotavljala prepletenost obeh procesov v neprofitnih organizacijah. Organizacije, v katerih je prepoznati močan management in močno vodenje, so visoko učinkovite in po mnenju avtorjev v neprofitnem sektorju redke. Za neprofitne organizacije s šibkim managementom in močnim vodenjem je značilno, da pri zaposlenih vlada zmeda glede njihovih vlog in odgovornosti, saj večino odločitev sprejema »močan « vodja. Šibkost obeh procesov povzroča životarjenje organizacije, ki sicer ne propade, ampak nekako »obvisi«. Organizacije, v katerih vladata močan management in šibko vodenje, so stabilne, vendar brez velikih razvojnih prizadevanj. Slika 2 prikazuje vse štiri situacije.

Procesa managementa in vodenja sta neločljivo povezana in nujna za uspeh vsake organizacije (Ott 200I, 93). Po Ottovem mnenju (200I, 95) manager nosi odgovornost za porabo organizacijskih virov in pri tem uporablja legitimno avtoriteto, ki izhaja iz njegovega formalnega položaja, vodja pa uporablja svoj vpliv, ki je neodvisen od njegovega formalnega 
položaja. Ta njegova neformalna sposobnost vplivanja je bistvenega pomena, da doseže tisto, kar misli, da mora biti narejeno.

Prepletanje procesov managementa in vodenja prepoznamo tudi pri Možini (1994, 33), ki govori o dvojni usmerjenosti managerjev. Prva usmerjenost je $\mathrm{v}$ povezavi z zaposlenimi in je vezana na posameznika ter njegovo nalogo in na celoto dela oz. na vse zaposlene. Druga usmerjenost je vezana na časovno dimenzijo (današnje stanje in potrebe napram jutrišnjemu stanju in zahtevam). Tretja usmerjenost managerjev pa se kaže v skrbi za takojšnje rezultate ter dolgoročne cilje.

Tudi Prevodnik in Biloslavo (2009, 93) ugotavljata, da sta v praksi potrebni obe orientiranosti vršnega in srednjega managementa, managerstvo in voditeljstvo. Prva teži k stabilnosti, druga k spremembam. Za dolgoročno uspešnost organizacij pa je potrebna ustrezna izmenjava obeh orientiranosti. Kot trdita avtorja (prav tam), nikakor ne moremo govoriti o izpodrivanju ene na račun druge.

Kotter (I998c, 39) ugotavlja, da so poslovne organizacije preveč »managerirane « in premalo vodene, premalo je strateškega in vizionarskega vodenja, preveč pa managerskega vodenja. Organizacije z močnim managementom in šibkim voditeljstvom zatrejo kreativnost in inovativnost ter so zelo birokratske. Kovač (1996, 126) navaja, da je organizacija $\mathrm{z}$ močnim managementom in šibkim vodenjem kratkoročno usmerjena, njeno poslovanje je rigidno in neprilagodljivo. Organizacije z močnim vodenjem in šibkim managementom pa so sicer nagnjene k dolgoročnim vizijam in spodbujanju kulture sprememb, vendar brez pravega nadzora in discipline pri reševanju svojih problemov. Brez učinkovitega managementa bi v današnjih kompleksnih organizacijah nastala kaos in ogrozitev eksistence. Najuspešnejše organizacije svoj uspeh gradijo na močnem vodenju in učinkovitem managementu ter si prizadevajo razvijati potencial zaposlenih v obe smeri (ILM 2007, 3), v smeri pridobivanja tehničnih veščin, kot so npr. kakovost, finance, projektni management, ter vodstvenih veščin, kot so npr. komunikacija, motiviranje, veščine na področju odnosov idr. Management in voditeljstvo sta komplementarna procesa, ne moreta delovati drug brez drugega (Verle in Markič 20 I 2, 82) - managerji predstavljajo stabilnost, voditelji stremijo k spremembam.

\section{Kaj je vodenje?}

Enoznačne definicije vodenja iz obsežne literature ni možno izluščiti, kar ugotavljata tudi Bass (1990, I I) in Yukl (1998, 2), ki pravita, da vsak avtor oblikuje svojo definicijo. Kljub temu da različni avtorji vodenje različno opredeljujejo, je opaziti skupni imenovalec večine definicij, ki vode- 
nje opredeljuje kot vpliv na sodelavce, da opravijo naloge, za katere vodja meni, da morajo biti narejene, oz. kot pravi Goodwin $(2006,72)$, pomeni vodenje: »... dosegati cilje skozi druge ljudi«. Pri vodenju ne moremo govoriti o enostranskem vplivu. Vodja sicer res vpliva na sledilce, vendar tudi ti vplivajo nanj. Kot ugotavljajo Gil idr. (2005, 324), je vodjev resnični vpliv odvisen od primernih zaveznikov, ugodne timske klime ter obstoja timov, ki se zavedajo svojih potencialov. Kouzes in Posner $(1987,8)$ v svoji definiciji vodenja izpostavljata odnosni vidik med vodjo in podrejenimi, pri čemer so prav podrejeni tisti, ki odločajo o tem, ali bodo nekomu priznali vodstvene sposobnosti ali ne.

Pointer in Sanchez (1993, 36-37) izpostavljata naslednje značilnosti vodenja:

- vodenje je proces - je aktivnost, opredeljena z glagolom in ne samostalnikom;

- težišče vodenja je oseba (vodja), zato je vodenje vedno osebno;

- vodenje se osredotoča na ostale posameznike in skupine;

- vodenje je akt vplivanja;

- vodenje je namensko in ne slučajno;

- namen vodenja je doseganje ciljev, ki bi jih posamezniki ne bili sposobni doseči samostojno;

- vodenje je večsmerno, poteka od zgoraj navzdol in obratno, v vse ostale smeri in izven organizacije.

Purvee in Enkhtuvshin (2015, I I2) pravita, da so vodje: $\gg$... ljudje, ki labko spreminjajo in usmerjajo organizacije ter labko podpirajo organizacijske inovacije in inovativna prizadevanja na različne načine $\times$. Jensen (20I2, 45) vodenje opredeljuje kot $\gg$ mehke« procese managementa, ki z veščinami komunikacije in sposobnostmi motiviranja dosegajo večjo zavzetost pri zaposlenih.

Levin in Crom (2000, 19) vidita vodenje globlje od managementa in menita, da pomeni: »... pomočljudem, da dosežejo tisto, za kar so sposobni; zasnovati vizijo za prihodnost; spodbujati, poucevati, svetovati, razvijati in ohranjati uspešne medsebojne odnose «. Podobno razlaga Lipičnik (1998, 3 I2), ki pravi, da je vodenje sestavni del širšega procesa managementa.

V okviru vodenja pa skušamo vplivati na ljudi, jih usmerjati in pripraviti do tega, da delo opravijo, kar se da najboljše. Vodja pri svojem vplivanju uporablja različne vrste moči. Najbolj poznana in uporabljena French-Ravenova klasifikacijska taksonomija (1959, v Yukl 1998, I78) definira naslednje vrste moči: 
- Moč nagrajevanja: izvira iz možnosti vodje, da nagradi sodelavce. Sodelavci sprejemajo navodila vodje in pričakujejo, da bosta njihovo ustrezno vedenje in dobro opravljeno delo nagrajena, bodisi v obliki boljše plače, napredovanja na delovnem mestu, dodatnega izobraževanja bodisi v nematerialnih oblikah nagrajevanja, kot so priznanje in pohvala ter druge ugodnosti, ki pripomorejo $\mathrm{h}$ kakovosti delovnega življenja in k privlačnosti dela za zaposlenega (Treven 1998, 233).

- Močprisile: štejemo med negativno vrsto moči, saj izvira iz strahu sodelavcev pred kaznijo. Vodja uporablja različne načine prisile in kaznovanja. Ta vrsta moči je manj učinkovita kot prejšnja.

- Legitimna moč: izvira iz formalnega položaja vodje, ki ima avtoriteto in pristojnosti, da nadzira vedenje drugih. Sodelavci se podrejajo vodji, ki zaseda višje mesto v hierarhiji organizacije.

- Ekspertna moč: izvira iz izkušenj ter specializiranega strokovnega znanja vodij. Zaposleni so prepričani, da vodja določene naloge najbolje opravi.

- Referenčna moč: izhaja iz identifikacije sodelavcev z vodjo. Ta karizmatični vpliv vodje na sodelavce se kaže v tem, da mu želijo biti čim podobnejši, ga občudujejo in mu sledijo.

Moč v managementu ni vedno uporabljena s pozitivnimi nameni ter $\mathrm{v}$ dobrobit organizacije in njenih članov. Biloslavo (2010, 74-80) navaja tri paradigme $\mathrm{v}$ dojemanju moči:

- Prva je managerska paradigma moči, ki jo njeni avtorji razumejo kot negativen pojav v organizaciji. Izraža se kot sposobnost posameznika ali skupine, da vpliva na druge posameznike ali skupine. Lahko obstaja izven formalne hierarhične strukture in procesov, kar lahko povzroča tudi dezorganizacijo. Nekateri avtorji te paradigme povezujejo moč z nadzorom nad redkimi viri v organizaciji, drugi avtorji pa opozarjajo na simbolen pomen moči, ki se izraža skozi komunikacijo in se uporablja za uresničevanje določenih ciljev.

- Druga paradigma je kritična paradigma moči, izhajajoča iz prepričanja, da je moč sredstvo dominacije managementa nad ostalimi člani organizacije, ki se kaže v uveljavljanju njihovih ozkih interesov na račun ostalih deležnikov. Moč položaja ne izhaja iz strokovne avtoritete in se večinoma izraža v zaodrju, ne neposredno vsem na očeh. Posamezniki in skupine svojo moč uresničujejo tako, da ostalim posameznikom ali skupinam pre- 
prečujejo izpostavljanje njihovih interesov. Moč se uporablja za oblikovanje percepcije ljudi tako, da ti sprejmejo podrejeno vlogo, ker ne vidijo drugih alternativ. Uveljavljanje moči poteka skozi formalno strukturo in procese, kot tudi skozi kulturne artefakte (simbole, zgodbe, anekdote) in je namenjeno izključno ohranjanju privilegiranega položaja ene skupine. Management in strukture, ki ga podpirajo, sistematično uporabljajo izkrivljeno komunikacijo za prekrivanje neravnotežja moči. Moč managementa je v okviru te paradigme namenjena predvsem ustvarjanju uporabnih, ustrežljivih in discipliniranih delavcev.

- Tretja paradigma je postmoderna paradigma moči, ki moč razume kot nekaj, česar ni mogoče obvladovati, usmerjati ali izrabljati. Pojavlja se izven posameznika, v razmerjih in pomeni mrežo moči, katere del je vsak od nas. Moč ni koncentrirana pri eni osebi. Različne družbene skupine so enakomerno vpete v mrežo moči, zato je avtoriteta managementa odvisna predvsem od razmerij teh moči in prevladujočega diskurza med njimi.

Mnogi avtorji (Goleman, Boyatzis in McKee 2002, 2 I; Lawrence, Ruppel in Tworoger 2014, 27I) pri vodenju izpostavljajo predvsem čustveno vlogo vodij, katerih naloga je usmerjati čustva skupine v pozitivno smer in odstranjevati motnje, ki jih ustvarjajo negativna čustva. Čustva morajo biti prepoznana, sprejeta in upoštevana (Lawrence, Ruppel in Tworoger 2014,262 ). Čustveno-inteligenčnim sposobnostim vodij Goleman, Boyatzis in McKee (2002, 3I) pripisujejo vpliv na »utrip«v organizaciji in razpoloženje zaposlenih ter s tem posledično na dobro opravljeno delo. Omenjene sposobnosti pomenijo najprej »znati upravljati sebe in svoja čustva«, potem pa še odnose z drugimi (Goodwin 2006, 102). Na tem mestu moramo izpostaviti rek kitajskega filozofa, Lao Ceja, ki pravi, da je obvladovanje drugih moč, obvladovanje sebe pa resnična sposobnost. Odličen vodja mora zaznati čustvene tokove, ki vplivajo na sposobnost ljudi, da delajo najbolje (Goleman 20ı0, 266). Pri tem je najpomembneje, da vodja ugotovi, kakšne so njegove prednosti in jih tudi stalno izboljšuje (Drucker 1999, I60). Weisinger (2001, 30) trdi, da je prav visoka stopnja samozavedanja temelj čustvene inteligence, ki jo vodja lahko povečuje z razvijanjem dobrih komunikacijskih sposobnosti ter sposobnosti za medosebne odnose. Avtor (Weisinger 200I, I 47-I 48) tudi trdi, da učinkovito in uspešno komunikacijo omogočajo naslednje sposobnosti:

- $\quad$ samorazkrivanje: vodja mora jasno povedati, kaj misli, čuti in hoče; 
- odločnost: pomeni braniti svoje mnenje, ideje in prepričanja ter to spoštovati tudi pri drugih;

- kritika: pomeni konstruktivno povedati svoje mnenje in občutke o idejah oz. dejanjih drugega;

- $\quad$ sinamično poslušanje: pomeni slišati tisto, kar drugi zares govori.

- skupinska komunikacija: je komunikacija v skupinski situaciji.

V učečih se organizacijah, med katere lahko uvrščamo tudi bolnišnice, morajo vodje danes izkoristiti posebna znanja in sposobnosti vsakega zaposlenega ter spodbujati njegove interese, pobude, razprave in prizadevanja za stalno učenje (Dimovski idr. 2005, 23I). Da prihaja čas za misleča okolja, meni tudi V. Bulc $(2006,55)$. Po avtoričinem mnenju (prav tam) $\mathrm{v}$ ospredje stopajo predvsem odnosi, ki so temelj voditeljstva. Vzvodi, kot so npr. ISO- standardi, so preveč statični, čeprav so oblikovani na ravni procesov, so še vedno preveč neosebni oz. predaleč od ljudi, zato vodjem predlaga, da naj namesto o procesih razmišljajo o ljudeh oz. $\gg 8+\mathrm{I} \ll$ temeljnih odnosih: odnosu vodstva do zaposlenih, odnosu med zaposlenimi, odnosu do poslanstva, odnosu do narave, odnosu do strank, odnosu do dobaviteljev, odnosu do javnosti, odnosu do lastnikov. Zadnji, deveti odnos, pa je odnos do samega sebe: samospoštovanje, razumevanje lastnih prednosti in šibkosti.

Uspešnejša je organizacija, ki se je sposobna učiti hitreje (Ferjan I999, I25). Drucker (1999, I 4I) meni, da je naloga vodij skrb za produktivnost umskih delavcev, za katero trdi, da je danes takšna, kot je bila produktivnost fizičnih delavcev pred roo leti. Spraševati se je treba, kaj je naloga umskega delavca. Dati jim je treba avtonomnost in prenesti odgovornost za njihovo produktivnost na njih same. Pri tem pa jih je treba obravnavati kot sredstva in ne kot stroške, jih obravnavati tudi tako, da si bodo želeli delati za ustanovo. Farrukh in Waheed $(2015,77)$ menita, da morajo vodje v učeči se organizaciji prevzeti veliko vlog, »od načrtovalca, mentorja in nadzornika «, pri tem pa morajo graditi skupno vizijo, razvijati ljudi okrog sebe in izzivati mentalne modele. Le učeča se organizacija se je sposobna prilagajati današnjemu turbulentnemu okolju ter hitrim spremembam. Senge (1990, I3), avtor koncepta učeče se organizacije, meni, da ne zadošča le učenje posameznikov, temveč je potrebno timsko učenje oz. učenje drug od drugega. 


\section{Vodenje kot proces}

Vodenje je kompleksen in zapleten proces in iz nepregledne množice strokovne literature težko izluščimo enoznačno definicijo. Zato nas ne čudi trditev, da je definicij o vodenju toliko, kot je njihovih avtorjev (Bass 1990, II; Yukl I998, 2). V nadaljevanju izpostavljamo le nekaj teh definicij.

Vodenje je dinamičen proces, v katerem poleg vodje sodelujejo tudi zaposleni in vzajemno vplivajo drug na drugega (Northouse 2001,3 ). Jensen $(2012,45)$ opredeljuje vodenje kot »mehke« procese managementa, ki z veščinami komunikacije in sposobnostmi motiviranja dosegajo večjo zavzetost pri zaposlenih.

Goodwin $(2006,72)$ vodenje definira kot proces interpersonalnih aktivnosti, pri katerem je po njegovem mnenju pomembno: (I) doseganje konsenza, (2) participativno odločanje, (3) delegiranje odgovornosti in (4) opolnomočenje (angl. empowerment) zaposlenih.

Vodenje je usmerjanje sodelavcev in vplivanje nanje. Pri tem vodja oblikuje vedenje posameznikov in skupine ter jih motivira, da naloge čim bolje opravijo ob čim manjši porabi energije in čim večjem zadovoljstvu (Krištof, Martinčič in Vrčko 2009, 73).

Če vodenje razumemo kot koncept, potem je največkrat obravnavano $s$ treh perspektiv: osebe, pozicije in procesa (DaCosta 2012, 575). Pri tem ima avtorica $\mathrm{v}$ mislih osebne karakteristike vodij in njihov položaj $\mathrm{v}$ organizaciji. Po njenem mnenju (prav tam) se lahko vodenje v zdravstvu obravnava kot socialni proces, pri katerem imajo ljudje na vodstvenih pozicijah s svojim vplivom možnost transformirati (spreminjati) svoje organizacije.

Zdravstvene organizacije uvrščamo med organizacije z visoko stopnjo znanja pri zaposlenih. Visoko usposobljeni timi imajo ekspertna znanja. Pri vodenju ekspertnih timov $\mathrm{z}$ uspešnimi in učinkovitimi posamezniki mora biti vodja pozoren na šest aktivnosti (Goodwin 2006, I I5):

- ustvarjenje jasne vizije prihodnosti, kajti tim potrebuje jasne cilje, da lahko meri svoj napredek in uspeh;

- pozorno izbiranje članov tima z ustreznimi izkušnjami, ki se zahtevajo za dosego ciljev;

- redno in $\mathrm{v}$ določenih časovnih intervalih pregledovanje timskih procesov;

- fokusiranje na strategijo;

- kreiranje klime zaupanja in integritete, da lahko člani tima odprto izražajo svoje poglede, vključno z nestrinjanjem; 
- dajanje osebne in timske povratne informacije ter nagrajevanje članov tima z možnostjo osebnega razvoja in prihodnje kariere.

Literatura omenja mnoge procesne sestavine vodenja. Izpostavljene so: komunikacija, nekatere lastnosti vodij, predvsem integriteta in kredibilnost, vizionarstvo. Najnovejše študije pa se fokusirajo na vodstvene kompetence, kjer so v zdravstvu izpostavljene naslednje (O'Neil in Morjikian 2003, 174-75):

- samozavedanje: zmožnost razumeti in razvijati sebe $\mathrm{v}$ kontekstu organizacijskih izzivov;

- medosebna in komunikacijska učinkovitost: zmožnost prevesti vizijo in strategijo $\mathrm{v}$ privlačna in motivacijska sporočila;

- prevzemanje tveganja in kreativnost: zmožnost preoblikovati sebe in organizacijo $\mathrm{z}$ nadgradnjo tradicionalnih vzorcev in načinov delovanja;

- navdihovanje in vodenje sprememb: zmožnost za navduševanje zaposlenih in stalno implementiranje sprememb;

- vizionarstvo: zmožnost povezati socialne, ekonomske in politične spremembe v strateško usmeritev organizacije.

Verle in Markič (20I2, 89) uspešno izvajanje nalog vodenja povezujeta $\mathrm{z}$ dobro razvitimi kompetencami managerjev na področjih, kot so: osebnost človeka, komunikacija, motivacija, načini in modeli vodenja, prenašanje znanja, timsko delo, odločanje, gradnja organizacijske kulture in vzpostavljanje primerne klime, organiziranje dela, kakovost vodenja in ocenjevanje uspešnosti dela. Komunikacija je zelo pomembna vodstvena veščina. Tradicionalni pogled jo obravnava kot aktivnost, s katero vodja zaposlene usmerja v to, kaj bi zaposleni morali delati. Hamrefors (2010, 149) pa ugotavlja, da moderne in inovativne organizacije nič več ne usmerjajo ljudi in jim postavljajo okvire, kaj lahko in česa ne, temveč jih spodbujajo $k$ temu, da delajo nove stvari.

Gorišek in Tratnik $(2003,20)$ menita, da vsi »mehki« pristopi v vodenju potrebujejo tudi »trše « načine za izboljšanje dela ljudi, ki so po njunem mnenju naslednji:

- jasno določanje ciljev, ki morajo biti specifični, merljivi, obojestransko dogovorjeni, usmerjeni $\mathrm{k}$ rezultatom in časovno določe$\mathrm{ni}$

- zagotovitev boljših, pravočasnih, pogostejših in .;celovitejših informacij o strategiji, uresničevanju ciljev in tekočih dosežkih organizacije 
- vključitev ljudi v kreiranje lastnih področij dela ter načrtovanje lastnega razvoja - predvsem tistih, ki morajo uporabljati nova orodja, metode in tehnike dela;

- zagotovitev močnih finančnih in nefinančnih spodbud, ki so neposredno vezane na nadpovprečni uspeh;

- oskrba ljudi z usposabljanjem »just in time«, osredotočenim na specifične potrebe.

Avtorja (prav tam) predlagata politiko »odprtih vrat « oz. dosegljivost vodje za zaposlene ob vsakem času. Komunikacija naj bo jasna in pogosta, v obliki rednih sestankov, kakovostnih poročil, informativnih delavnic, internih časopisov ipd.

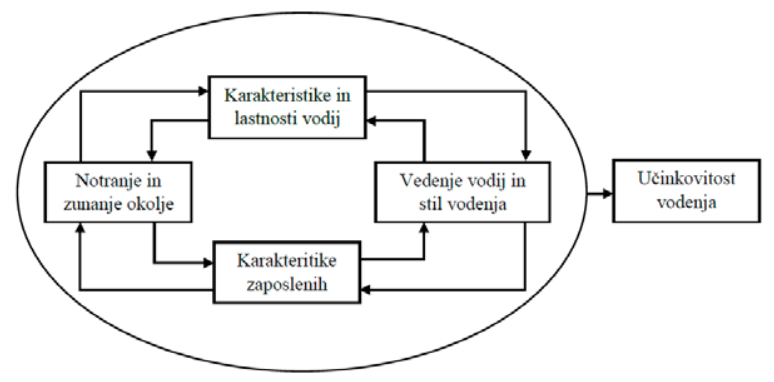

Slika 3: Okvir za razumevanje vodenja

Vir: Robbins 1997, v Dubrin 2004, 22.

$\mathrm{Na}$ proces vodenja imajo vpliv vsaj trije dejavniki: vodja, zaposleni in okoliščine (ILM 2007, 17). Tudi Hersey in Blanchard (1993, 94) ugotavljata, da je proces vodenja funkcija vodje, sledilcev in okoliščin: $\mathrm{V}=\mathrm{f}$ (v, s, o). Vodenje ni abstraktna dejavnost, vedno poteka v praksi, pri kateri je treba upoštevati faktorje, povezane z vodjo (njegove karakteristike in osebnostne lastnosti, vedenje in stil vodenja), ter karakteristike vodenih in okoliščine (vezane na notranje in zunanje okolje organizacije). Karakteristike in osebnostne lastnosti vodje se nanašajo na njegove notranje kvalitete, kot sta npr. samozavedanje in zmožnost reševanja problemov. Vedenje in stil vodenja se nanašata na pristop $k$ vodenju oz. na to, kako pogosto vodja pomaga svojim podrejenim (mentoriranje, podporno vodenje), ali jih morda vključuje v odločanje o zadevah, ki se tičejo njihovega dela (participativni stil vodenja) ipd. Karakteristike zaposlenih pa se nanašajo na njihove lastnosti, pomembne za delo, kot npr. inteligentnost, motivacijo za delo, samoiniciativnost ipd. Poleg faktorjev, poveza- 
nih $\mathrm{z}$ vodjo in vodenimi, na učinkovitost vodenja vplivata tudi notranje in zunanje okolje (Dubrin 2004, 22). Slika 3 prikazuje okvir za razumevanje procesa vodenja.

Dimovski idr. (2005, 235) vidijo področje ravnanja z ljudmi pri delu kot najpomembnejše področje $\mathrm{v}$ procesu vodenja učeče se organizacije. Avtorji menijo (prav tam), da se novi izzivi pojavljajo predvsem pri razvoju motivacijskih shem in sistemov nagrajevanja, ki naj bi temeljili na posameznikovi pripravljenosti za aktivno deljenje znanja z drugimi člani organizacije. Pogoj za to je procesni (horizontalni) organizacijski ustroj, v katerem so timi organizirani okrog ključnih procesov. Kadri so prožni in opolnomočeni. Vodoravna struktura spodbuja horizontalno komunikacijo in sodelovanje.

\section{Se vodja rodi ali naredi?}

Pri avtorjih je zaslediti odgovor, da velja oboje (Kovač, Mayer in Jesenko 2004, 57; Hočevar, Jaklič in Zagoršek 2003, 188). Genetika pri pojavu transformacijskega vodenja igra pomembno vlogo (Walumbwa in Zhu 2004, 35). Dedne dispozicije so pomembne (Mayer 2003, 37I), toda geni sami po sebi niso zadostni. Raziskave kažejo, da je vpliv dednosti približno so-odstoten, toda brez interesa, znanja in veščin tudi gensko predispozicioniran človek nikoli ne bo postal dober vodja. Vodenje lahko primerjamo s športnikom. Še tako dober talent brez trdega treninga ne uspe in enako velja za vodjo: imeti mora močno motivacijo za vodenje (Možina idr. 1996, 94), ter željo po razvoju voditelja v sebi (Hansen in Batten 1998, 38). Vodstvenih veščin se je možno naučiti na različne načine (Hočevar, Jaklič in Zagoršek 2003, 193-211):

- v obliki neformalnega učenja preko izkušenj, poskusov in napak;

- z opravljanjem različnih nalog na delovnem mestu;

- preko ljudi, s katerimi je vodja obkrožen, najpomembnejši pa so nadrejeni, vrstniki in mentorji;

- preko formalnega učenja $\mathrm{v}$ programih razvoja vodenja, ki so se na trgu zelo razširili;

- $s$ treningom in mentorstvom na delovnem mestu.

Gandossy in Verma $(2009,40)$ menita, da morajo uspešne organizacije $\mathrm{z}$ učenjem začeti prav pri vodjih. Avtorja razvoju voditeljstva posvečata veliko pozornosti, še posebej veščinam, ki so potrebne za vodenje kontinuiranih sprememb (Gandossy in Verma 2009, 42), kar se po njunem mnenju lahko dosega $\mathrm{z}$ rotiranjem na različnih delovnih mestih, mento- 
riranjem ter globalnim povezovanjem, kot nadgradnjo formalnemu šolskemu učenju.

Avolio in Bass (1998, v Walumbwa in Zhu 2004, 35) sta ocenila učinek usposabljanj pri i I5-tih voditeljih pred usposabljanjem in po njem ter ugotovila, da sta po usposabljanju signifikantno narasli dimenziji transformacijskega vodenja $\mathrm{v}$ povezavi $\mathrm{z}$ intelektualnim stimuliranjem zaposlenih ter njihovim motiviranjem.

Elmuti, Minnis in Abebe (2005, 1019) ugotavljajo, da je vodenje veščina, povezana z vedenjem, ki izkazuje to veščino. Prav to pa je njihov (prav tam) argument, da se vodja lahko uči, raste in spreminja. Predlagajo multidisciplinarni, večstopenjski in globalno usmerjen program izobraževanja vodij (Elmuti, Minnis in Abebe 2005, 1022-26). Prvi nivo predstavlja osnovno znanje o financah. Med najpomembnejše veščine tega nivoja uvrščajo računalniške, matematične ter veščine pisnega izražanja. Vse to so znanja, ki jih lahko pridobimo med študijem. Drugi nivo predstavljajo medosebne veščine (komunikacijske, timsko delo, reševanje konfliktov, občutljivost za kulturne razlike) ter konceptualne veščine, kot so strateško planiranje, obvladovanje kakovosti, etično ravnanje, globalna orientiranost in management sprememb. Tretji (in morda tudi najtežji) nivo njihovega predlaganega izobraževalnega modela pa pomeni razvoj veščin skozi praktični trening vodij na njihovem delovnem mestu, mentorstvo, coaching in druge praktične programe usposabljanja.

Weil (2014, 30) vodjem ameriških akademskih oz. terciarnih zdravstvenih centrov predlaga program enoletnega podiplomskega izobraževanja, sestavljenega iz šestih modulov.

- Vsebine modula A: pregled notranjega in zunanjega okolja organizacije, upravljanje, organizacijska kultura, vrednoste, vizija organizacije, uporaba čustvene inteligence, socialna psihologija, pogajalske veščine, reševanje konfliktov, politika, regulatorno okolje, demografski trendi, fiskalna vzdržnost, vrednotenje kvalitete oskrbe idr.

- Vsebine modula B: ekonomski, politični in socialni vidiki zdravstvenega sistema.

- Vsebine modula C: financiranje zdravstvenih storitev, stroškovne podlage, sistem zdravstvenega zavarovanja

- Vsebina modula D: organizacija, management, človeški viri.

- Vsebina modula E: prezentacije aktualnih tem, diskusija, timsko delo.

- Vsebina modula F: praktično učenje skozi študije primera (različne vsebine). 
Razvoj vodstvenih veščin je tesno povezan $\mathrm{z}$ osebno rastjo človeka. Hočevar, Jaklič in Zagoršek (2003, 190) trdijo, da se je dobrega vodenja težko naučiti ravno zato, ker zahteva človekovo celostno spremembo, poleg tega pa je najboljši način za razvoj vodstvenih sposobnosti ravno učenje preko izkušenj, poskusov in napak.

\section{Vodenje sprememb}

Pregled relevantne literature kaže, da mnogi avtorji (Mauer 20I Ib, 33; Arnett 2010, 40; Bukovec 2005, 44; Evans in Russell 1992, 40; Drucker 1999, 38; Tracy 2000, 34; Menaker 2009, 341; Kovač, Mühlbacher in Kodyek 2012, 65; Martin idr. 2014, I03) pripisujejo vodenju oz. veščinam in znanju vodij v procesu uvajanja in obvladovanja sprememb velik pomen. Olson in Eoyang $(2001,33)$ izpostavljata tri pomembne naloge današnjih vodij: (I) postavitev okvirjev, ki se nanašajo na cilje, pričakovanja, timsko delo, financiranje; (2) osredotočanje na značilne razlike v najproduktivnejših vedenjskih vzorcih, ki se nanašajo na različne poglede, izkušnje, kulture, in (3) izmenjavo informacij o spreminjanju.

Nekateri avtorji (Fickenscher in Bakerman 2011, 66; Kotter 1998b, 32) trdijo, da je uvedba učinkovite in trajne spremembe $v 80 \%$ odvisna od vodenja in le v $20 \%$ od managementa. Omenjeni avtorji (prav tam) vodenju za spremembe pripisujejo naslednje aktivnosti: določitev ustrezne smeri (ciljev), naravnanje organizacije na te cilje, motiviranje in navdihovanje vseh zaposlenih ter poudarjanje koristi za paciente in organizacijo. Procesu managementa pa pripisujejo operativno načrtovanje, skrb za proračun (budžet), organiziranje in reševanje problemov. Najpomembnejša naloga vodenja oz. voditeljstva $\mathrm{v}$ procesu uvajanja in obvladovanja sprememb je stalno analiziranje okolja in preverjanje, ali se začrtani cilji (vizija) z ustrezno strategijo v praksi tudi udejanjajo.

Spreminjanje udobnih rutin je zahtevno delo. Sprememba odpre Pandorino skrinjico problemov, velikokrat trivialnih, toda vsak izmed njih lahko ogrozi izvedbo (Sayles 1999, 231). Organizacije morajo biti organizirane za nenehne spremembe, pri čemer je njihova funkcija, da znanje usmerjajo v delo (Drucker 2004, I29). Avtor (Drucker 2004, I3I) predlaga, da pri tem izhajajo iz treh sistematičnih praks:

- nenehno izboljševati vse, kar organizacija počne (z Japonske izhajajoč proces kai zen);

- naučiti se izrabljati svoje znanje (znanje zaposlenih);

- naučiti se inoviranja. 
Nekateri raziskovalci (Pucelj in Likar 2006, 138) ugotavljajo, da je prav vodenje ključni in najpomembnejši dejavnik za spodbujanje predlogov za izboljšave oz. inovacije. V svoji raziskavi avtorja (prav tam) ugotavljata, da v 70 odstotkih primerov vodenje ključno vpliva na inovacijsko kulturo v neki organizaciji oz. v naši družbi. Gradnjo kulture inoviranja pospešuje t. i. porazdeljeno vodenje (angl. shared oz. distributed leadersip), ki je primerno v času hitrih sprememb (McCrimmon 2005, I064). Gre za obliko neformalnega vodenja, pri katerem vodja svojo moč oz. možnost odločanja porazdeli med ostale člane tima. Takšno vodenje je še posebej pomembno v okoljih, v katerih so inovacije ključnega pomena za uspeh organizacije.

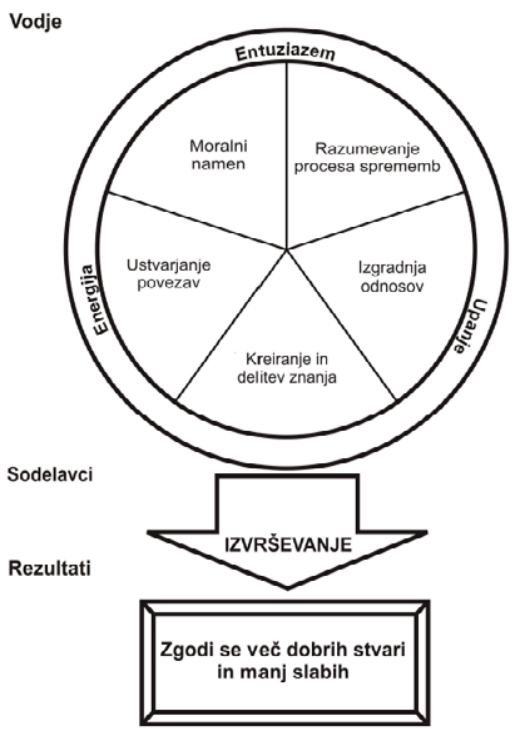

Slika 4: Ogrodje za vodenje

Vir: Fullan 2001, 9 .

Fullan (200I, 3-II) gre v svojih razmišljanjih še dlje. Zaradi kompleksnosti današnjih problemov meni, da je poleg kreiranja znanja potrebna tudi njegova delitev med zaposlenimi. Izraba usvojenega znanja poteka na način, da ga zaposleni ne zadržujejo zase, ampak ga skozi reševanje problemov delijo med seboj. Današnji vodje sprememb morajo nujno razumeti procese spreminjanja. Inovativne ideje ne zadoščajo, pomembno je razumeti način, kako jih spraviti v življenje. Fullanovo (200I, 5) razumevanje procesa spreminjanja Drucker (2004, I29) enači z učenjem inoviranja. Pri 
vodenju sprememb kot pomembne komponente Fullan izpostavlja izgradnjo odnosov in sodelovanje med zaposlenimi ter ustvarjanje povezav. Pri tem pa mora vodjo usmerjati moralni namen, ki se kaže v skrbi za dobrobit sodelavcev, strank ter družbe kot celote. Avtor meni, da je z uporabo omenjenih petih komponent učinkovitega vodenja možno pri sodelavcih izvabiti entuziazem in upanje, da so rešljivi najtežji problemi. Predpogoj pa je, da vodja sam verjame $\mathrm{v}$ spremembo, je navdušen in predan spreminjanju (Fullan 200I, 7). Le s takim načinom vodenja se zgodi več dobrih in manj slabih stvari. Avtorjevo ogrodje za vodenje sprememb prikazuje slika 4.

Ustrezen pristop $\mathrm{k}$ dvigu produktivnosti umskega delavca je naloga vodstev, ki morajo slediti naslednjim korakom (Drucker 2004, 168):

- opredeliti nalogo;

- osredotočiti delo na to nalogo;

- opredeliti uspešnost;

- zaposlenega postaviti za partnerja pri izboljševanju uspešnosti in ga obravnavati kot prvi vir idej za to izboljševanje;

- vključiti nenehno učenje in poučevanje v delo vsakega zaposlenega in delovne skupine, kajti usposabljanje je zgolj začetek učenja; umski delavci se največ naučijo, kadar poučujejo.

Nosilec sprememb v organizaciji je managerski vrh. To je vodilni kader, ki ima veliko znanja, izkušenj, poguma in smisla za sodelovanje z drugimi ljudmi. Pri delu jasno izražajo svoja stališča. Pri vodenju jim dostikrat pomaga njihova karizma, s katero še lažje spreminjajo organizacijsko kulturo. Njihova pomembna značilnost je tudi vizionarstvo in sposobnost prenašanja vizije na ostale zaposlene, saj mora vodja izražati strast in navdušenje, $s$ katerima začrtano vizijo spreminja $v$ realnost (Branden 2000, 62). Pri vodenju sprememb (pa tudi pri vodenju nasploh) je pomembna lastnost vodij integriteta, ki jo Leigh $(2009,4)$ povezuje $s$ konsistentnim in z zakonitim delovanjem vodje ter $\mathrm{z}$ njegovimi moralnimi in etičnimi nameni.

Verle in Markič (2or 2, 9) pravita, da današnji vršni managerji potrebujejo mehke veščine (angl. softer skills), kot so: voditeljstvo, ravnanje z ljudmi in timsko delo. Le na ta način se bodo sposobni odzivati in prilagajati na spremembe. Kot trdita avtorja (Verle in Markič 20I2, 69), vodenje ne bo več možno s slabimi managerji. Zaradi skrbi za zadovoljstvo uporabnikov in zadovoljstvo zaposlenih se od lastnikov in vršnih managerjev zahteva nov sodelovalen pristop pri organiziranju ter usmerjanju zaposlenih. 
Poslovni načrt je metodološko orodje za uvajanje poslovnih sprememb, organizacijska kultura pa je način njihove izpeljave (Kovač i996, 2 I). Avtor (prav tam, Io9) organizacijsko kulturo opredeljuje kot socialni cement organizacije, ki s svojimi neformalnimi pravili usmerja različnost zaposlenih in omogoča koordinacijo ter nadzor nad njihovimi interesi. Uvajanje sprememb včasih zahteva tudi spreminjanje oz. kreiranje nove organizacijske kulture, kar vodjem predstavlja zelo težko opravilo. Gilster (2002, 234- 235) meni, da vodja v zdravstvu lahko kreira skrbno, čutečo in toplo kulturo le na način, da je sam predan služenju pacientom in zaposlenim, jim zna prisluhniti ter spoštuje in ceni vsakega posameznika. Naslednja predanost, ki jo mora izkazovati, je predanost viziji in poslanstvu ter nenehnemu izobraževanju zaposlenih. Izkazovati mora skrb za zaposlene in prisluhniti njihovim idejam. Predvsem pa mora dobro poznati samega sebe.

\section{Narava in koncepti spreminjanja}

Pritiski po spremembah prihajajo z vseh strani - globalizacija, financiranje, zakonodaja, zahteve po izboljševanju kvalitete idr. Ritem oz. hitrost same spremembe na splošno narašča in se mu ne da izogniti. Sprememba je konstantna in neizbežna značilnost osebnega, profesionalnega in organizacijskega življenja, ki nastaja kot posledica zaporedja mnogih nihanj (Pennington 2003, 4) povezanih z/s:

- družbenimi, ekonomskimi in političnimi pritiski;

- odkritji in tehnološkimi inovacijami;

- novimi zahtevami potrošnikov;

- premiki marketinških vzorcev;

- spremembami zakonov in predpisov in

- okoljskimi katastrofami.

Raziskovalci so klasificirali organizacijske spremembe glede na odzive organizacij na spremembe v okolju, glede na področje spremembe ter glede na njen ritem in naravo (Angel-Sveda 20I2, 74). Kot pravi avtorica A. Angel-Sveda (prav tam, 76), ima organizacija dve možnosti odziva na spremembe v okolju. Lahko vnaprej predvidi svoje reakcije in oceni tveganja (proaktivni pristop), lahko pa se zgolj prilagaja na vplive iz okolja (reaktivni pristop). V prvem primeru spremembo načrtuje (t. i. načrtovana sprememba), v drugem pa se sprememba »bolj zgodi « (nenačrtovana sprememba). Glede na način implementacije je sprememba lahko: (I) vsiljena s strani višjaeavtoritete, (2) participatorna, v katero so zaposleni aktivno vključeni in niso zgolj pasivni izvajalci in (3) uvedena na osnovi po- 
gajanj, pri katerih so $\mathrm{v}$ proces spremembe vključene le osebe, na katere bo imela vpliv. Strategije, ki jih management pri implementaciji spremembe uporablja, so lahko:

- od vrha navzdol (angl. top-bottom strategies), kjer managerji informirajo zaposlene o nujnosti spremembe;

- od spodaj navzgor (angl. bottom-top strategies), kjer je odgovornost za implementacijo prenesena na nižje nivoje hierarhične piramide;

- strategije reprezentativnih vlog, kjer se na novo zaposlijo osebe, na katere bo sprememba imela vpliv;

- pilotne strategije, pri katerih se identificira določen del organizacije, ki postane vodilni pri implementaciji.

Pomembno sporočilo literature managementa sprememb je, da spreminjanje na organizacijskem nivoju ni linearen in predvidljiv proces. Preživetje ni zagotovljeno vsem posameznikom ali organizacijam, preživijo najprilagodljivejši in ne nujno najmočnejši. Minili so časi, ko so se organizacije skozi različna obdobja sprememb premikale zaporedno in na koncu dosegle začrtano stabilno stanje. Pennington $(2003,4)$ pravi, da količina, obseg in kompleksnost sodobnih sprememb sprožajo občutek kontinuiranega toka dogajanj na vseh nivojih. Sprememba takšnega obsega nikoli ni absorbirana na naraven (normalen, organski) način in zahteva ekspliciten (jasen, natančen in nedvoumen) ter vešč management. To še posebej velja, če so roki za uvedbo sprememb kratki in se istočasno pojavlja več iniciativ na različnih področjih. Velik delež iniciativ po spremembah pade ali pa so le delno uspešne. Zavedanje o potrebnosti sprememb je relativno lahko doseči, mnogo težje pa je pridobiti podporo, predanost in široko zakoreninjenost novim pobudam. Organizacijska situacija »status quo « se ne žrtvuje čez noč, včasih so potrebna leta, da organizacija postane dovzetna za transformacijo. Sprememba struktur, procedur, stališč in načinov razmišljanja mora biti zamišljena kot postopen proces, ki na strani managerjev zahteva subtilno in vztrajno usmerjanje potrebnih aktivnosti v izvedbo spremembe, in ne kot vnaprejšnje definiranje dogodkov. Sprememba zahteva prostor in čas in se ne zgodi v trenutku. V praksi se spremembe pojavljajo po premikih $\mathrm{v}$ predhodnih stališčih in načinih razmišljanja oz. jih generirajo. Spremembo samo po sebi lahko opredelimo kot dogodek (npr. reorganizacija, zmanjšanje števila zaposlenih idr.), človeški odgovor nanjo pa je proces, ki vključuje raznolike reakcije, kot so: vznemirjenje, zmeda in različna čustva (Lawrence, Ruppel in Tworoger 20I4, 258). Spremembo označujejo jasno zaporedje aktivnosti, strategije, 
razumevanja, sprejemanja in prilagajanja na nove sisteme ali poteke dela. Lahko je sprožena (celo vsiljena) od zunaj ali pa gre za inovativno idejo tima znotraj organizacije (Norton 2007, I I 5). Avtor poudarja, da vsiljena sprememba povzroča negativna čustva pri ljudeh, ki se jih dotika, vendar bo uspešen vodja tudi $v$ situacijah $\gg$ mora se $<\mathrm{z}$ diskusijami z zaposlenimi razvil primerno strategijo za uvedbo spremembe. Predvsem transformacijski vodja mora razumeti odpore in mobilizirati energijo, ki je potrebna za transformacijo oz. uspešno uvedbo spremembe (Tichy in Devanna 1990, 72). Kot pravi Pennington (2003, 5), prav zaradi tega uspešna sprememba zahteva ne le tehnične kompetence managerjev, ampak tudi občutljivost za politične in človeške dimenzije organizacijskega življenja.

Drucker $(1999,77)$ trdi, da se morajo organizacije 21. stoletja preoblikovati v usmerjevalce sprememb. Meni, da sprememb ni moč obvladovati, možno jih je le usmerjati. Avtor usmerjevalcem sprememb priporoča 4 vodila:

- opuščati preteklost v smislu opustiti izdelek, storitev, trg ali proces, ker ti vežejo nase najproduktivnejše in najsposobnejše zaposlene;

- načrtno in nenehno izboljševati vse notranje in zunanje dejavnosti: izdelke, storitve, procese, trženje, servisne storitve, tehnologijo, usposabljanje in razvoj kadrov, uporabo informacij;

- priložnostim nameniti prav toliko časa (ali več) kot problemom, najsposobnejše kadre - dodeliti najbolj obetajočim priložnostim;

- razvijati politiko načrtne inovativnosti - ta spodbuja organizacijo, da v spremembah išče priložnosti.

Učinkovito izvajanje sprememb zahteva razumevanje njihove dinamike in razlogov zanje. Potrebna je preučitev silnic, ki pospešujejo spremembo, in silnic, ki spremembo zavirajo (Bennett 1997, 242). Avtor predlaga analizo teh silnic s preprostim diagramom, ki je prikazan na sliki 5 . Dolžina puščic predstavlja moč vpliva vsakega vključenega elementa. Diagram nakazuje dinamično naravo procesa spreminjanja, na levi strani prikazuje ključne pospeševalne faktorje, na desni strani pa ključne omejevalne faktorje.

Na področju javnega sektorja so po ugotovitvah nekaterih avtorjev (Andrews, Cameron in Harris 2008, 309) usmerjevalci sprememb soočeni še z drugimi dejstvi. Organizacijske spremembe so večinoma posledica zunanjih pritiskov, kar pomeni, da morajo še $\mathrm{v}$ večji meri upoštevati šir- 
še organizacijsko okolje, ki največkrat prevlada nad internimi organizacijskimi strukturami.

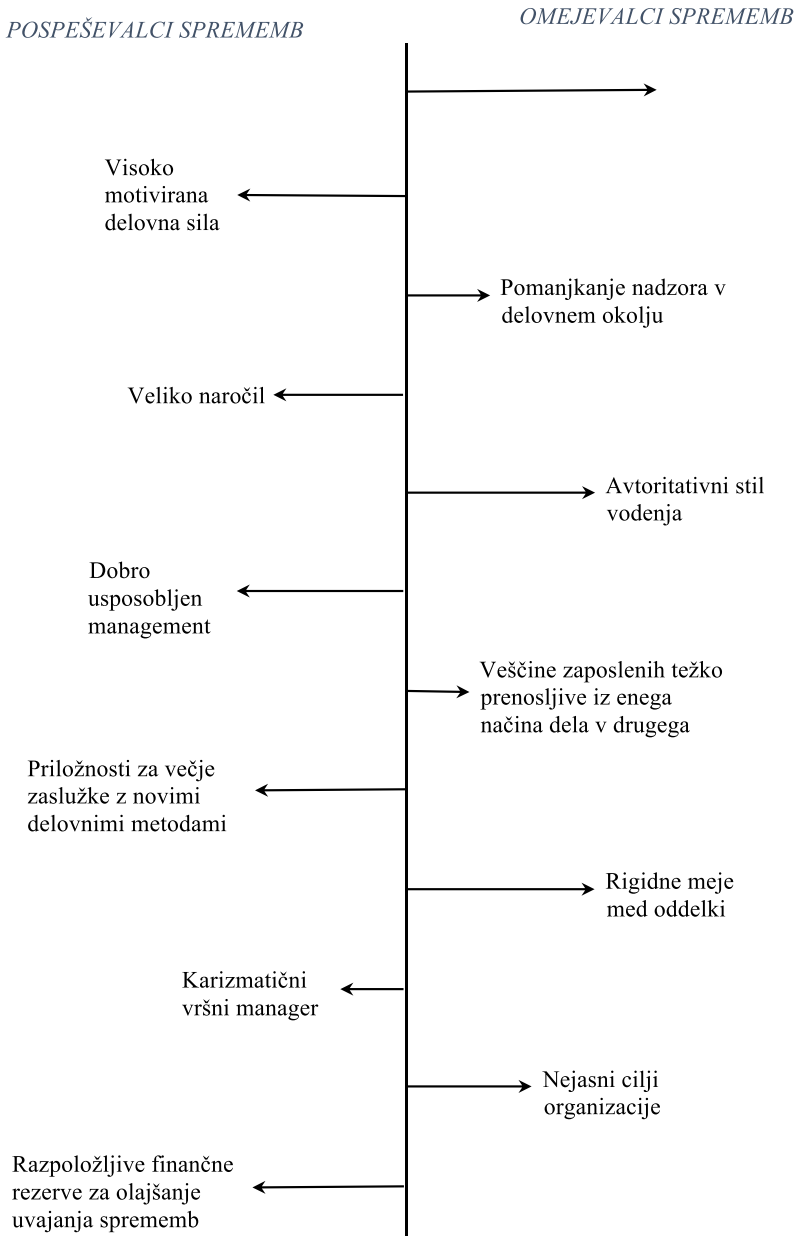

Slika 5: Primer preproste analize silnic

Vir: Bennett 1997, 243.

Organizacije se na spremembe odzivajo zelo različno. Ansoff (I98 I, v Tavčar 2000, 57) glede na njihovo naravnanost za spremembe opisuje pet tipov organizacij:

- ustaljene organizacije, ki so toge in usmerjene v preteklost;

- odzivne organizacije, ki se odzivajo na spremembe v okolju;

- predvidevajoče organizacije, ki spremembe že lahko predvidijo; 
- raziskujoče organizacije, ki same raziskujejo možnosti spreminjanja;

- ustvarjalne organizacije, ki same ustvarjajo priložnosti za uspeh.

Walker, Armenakis in Bernerth $(2007,762-64)$ kot pomebne faktorje uspešnega uvajanja organizacijskih sprememb navajajo nekaj različnih skupin.

- Vsebinski: so specifični in vezani na posamezno organizacijo; spremembe so pogosto označene kot temeljne ali inkrementalne. Temeljne so običajno povzročene $\mathrm{z}$ okoljskimi zahtevami ali novimi vladnimi regulativami. Za inkrementalne spremembe pa je značilna postopnost, premikanje korak za korakom proti organizacijskim idealom. Podobno občasne (epizodne) spremembe sprožijo notranji faktorji (npr. spremembo ključnih kadrov) ali pa zunanji faktorji (npr. nove tehnologije). Za kontinuirano spremembo pa je značilno konstantno nadgrajevanje oz. izboljševanje delovnih praks.

- Procesni: nanašajo se na aktivnosti med uvajanjem in izvajanjem predlagane spremembe. Agenti sprememb morajo pripraviti zaposlene na spremembo z odprto in pošteno komunikacijo. Obrazložiti morajo razliko med obstoječim in želenim stanjem ter izražati zaupanje v zmožnost organizacije za uvajanje sprememb.

- Kontekstualni: nanašajo se na stopnjo profesionalizma, tehnična znanja, managerske pristope $\mathrm{k}$ spremembam in določitev potrebnih virov. Zunanji kontekstualni faktorji so konkurenčni pritisk, zakonske in tehnološke spremembe, vladne regulative organizacija običajno nanje nima vpliva, spremembe mora izvesti kot odgovor na omenjene kontekstualne faktorje.

- Individualne razlike: zaposleni imajo različne osebne karakteristike in predispozicije, ki med spremembami lahko različno vplivajo na njihove reakcije.

McLean (201 I, v Hewitt-Taylor 2013, 35) opisuje dva vidika spreminjanja: spremembo in tranzicijo. Sprememba se nanaša na opazne stvari, ki se zgodijo ali so narejene, medtem ko tranzicija opisuje, kaj ljudje čutijo, izkusijo in vidijo kot pomembno. $\mathrm{V}$ praksi je potrebno preučiti oba vidika, čeprav je pozornost običajno bolj namenjena praktičnim vidikom oz. opaznim stvarem. Pomembno je premisliti tudi tranzicijske elemente; ali se ljudje počutijo vključene, kakšne izzive, grožnje in priložnosti jim prinašajo spremembe ter kaj bodo z novimi načini dela pridobili ali izgubili. Ljudje morajo biti prepričani, da je sprememba potrebna, še preden jo 
začnejo uvajati. Posamezniki in skupine zelo različno odreagirajo na specifične spremembe, od entuziastičnega odobravanja preko nevtralne zadržanosti do skeptičnega upiranja. Zaposleni se lahko vedejo zelo različno, ko so soočeni z neizogibno spremembo (Pennington 2003, 8).

Kakršna koli že je narava spremembe, njeno uvajanje in obvladovanje ni lahko delo, saj pri zaposlenih zahteva premik izven njihovih con udobja v nepoznane situacije in delovanja, kar pri mnogih povzroča strah. Slednji pa je učinkovito gorivo za različne odpore, ki so nujni spremljevalci $\mathrm{v}$ procesih spreminjanja organizacij. Everard in Morris $(1990,234)$ navajata, da je kompleksnost spremembe (imenujeta jo večdimenzionalnost) razlog za upiranje. Socialni sistem pa je tisti, ki se upira spremembi. Kot pravita avtorja (prav tam), v okviru tega sistema obstaja veliko število odnosov, norm, pridobljenih pravic ter drugih značilnosti, ki bodo s predlagano spremembo najverjetneje ogrožene.

\section{Odpori proti spremembam}

Zaposleni v organizacijah se na spremembe odzivajo zelo različno. Za določene ljudi so dobrodošle, sprejemajo jih kot osvežitev dela oz. z določeno mero vznemirjenja, spet drugi so previdnejši (nevtralni) ter opazujejo, kaj jim bo sprememba prinesla, tretja skupina zaposlenih pa se spremembi upira. Intenzivnost odporov je lahko izražena v razponu od blagega distanciranja do aktivnega sovražnega obnašanja, s poskusi zavlačevanja ter spodkopavanja ali celo ustavljanja spremembe. Prizadevanja za uvedbo spremembe v organizaciji bodo uspešnejša, če bo vodja razumel razloge za odpore do sprememb (Yukl ı998, 438).

Pardo del Val in Martinez Fuentes (2003, I53) sta v svoji empirični študiji ugotovili, da so odpori zaposlenih močnejši pri strateških (radikalnih) spremembah kot pri evolucijskih (postopnih, inkrementalnih). Tudi Mosadegh Rad (2005, 20) v raziskavi pokaže, da so bile največje ovire pri uvajanju sistema celovitega upravljanja kakovosti (angl. Total Quality Management - TQM) v zdravstvenih organizacijah na strani človeških virov, manj pa na strani procesov in struktur.

Connor (1995, v Yukl 1998, 439) navaja razloge za odpore proti spremembam:

- Pomanjkanje zaupanja v ljudi, ki spremembo predlagajo. Obojestransko nezaupanje lahko povzroči, da je vodja skrivnosten ali molčeč glede razlogov za spremembo, kar povzroči dodatno sumničavost pri zaposlenih in povečanje odporov. 
- Prepričanje, da je sprememba nepotrebna. Odpori so še toliko večji, če so trenutni načini delovanja organizacije uspešni in ni nobenih resnih težav. Znaki prihajajočih problemov so običajno na začetku zelo nejasni in jih ljudje spregledajo ali celo ignorirajo. Če vršni management pretirava z informacijami o tem, kako uspešna je organizacija, bo ljudi še težje prepričati v nujnost spremembe.

- Prepričanje, da sprememba ni uresničljiva. Takšno mnenje se še posebej ustvari pri radikalnih spremembah, ki se večini zaposlenih zdijo nemogoče. Zgodnji neuspehi pri uvajanju sprememb povzročajo cinizem in dvome o tem, da lahko naslednje spremembe uspejo.

- Ekonomske grožnje, ki povzročajo odpore pri ljudeh, ki jim bo sprememba prinesla zmanjšanje njihovega prihodka, koristi ali ogrozila varnost delovnega mesta. To se dogaja pri vpeljavi novih tehnologij, ki nadomeščajo delovno silo.

- Relativno visoki stroški. Čeprav sprememba na daljši rok pomeni korist za organizacijo, so zanjo vseeno potrebni določeni stroški.

- Strah pred osebnim neuspehom. Ljudje s pomanjkanjem samozavesti neradi menjajo obstoječe procedure, ki so jih vajeni, z novimi. Tovrsten strah se najlažje odpravlja $z$ učenjem novih načinov dela.

- Izguba statusa in moči. Večina sprememb v organizacijah povzroča določene premike $\mathrm{v}$ moči in statusu bodisi posameznikov ali posameznih enot. Ljudje, ki izgubijo status ali so celo »odrezani«, se spremembi močneje upirajo.

- Grožnja vrednotam in idealom posameznikov. Zaposleni se bodo močneje upirali spremembam, ki niso skladne z njihovimi pomembnimi vrednotami. Grožnje vrednotam in idealom povzročijo močna čustva, ki rodijo odpore.

- Zamere zaradi vmešavanja. Nekateri ljudje se upirajo, ker nočejo biti nadzorovani.

Načini, kako bodo ljudje reagirali na spremembe, so v pretežni meri odvisni od njihovih prepričanj (Trowler, Murray in Knight 2003, II). Prepričanja zaposlenih pa je možno spreminjati, še posebej v organizacijah, ki verjamejo v svoje zmožnosti po vpeljevanju inovacij, saj v svoje pristope vključujejo participacijo zaposlenih, e-učenje in zaposljivost skladno z organizacijskimi cilji. Delovne skupine v takšnih organizacijah lahko tvegajo in tudi prispevajo več, ker so obravnavane kot sistemi, ki imajo 
dovolj virov, intelektualnega in socialnega kapitala ter ekspertnega znanja kot kateri koli posamezni član organizacije. Spremembe bodo uspešne, če bodo vodje skrbeli za: (I) gradnjo intelektualnega in socialnega kapitala; (2) razvoj orodij in tehnik spreminjanja ter delovnih praks, pri katerih vsakdo razume, kdo kaj počne (Trowler, Murray in Knight 2003, I I). Intelektualni kapital predstavlja znanje organizacije - implicitno in eksplicitno. Socialni kapital pa so omrežja oz. povezave z drugimi, ki opravljajo podobne naloge. $V$ primeru, da zaposleni menijo, da inovacija ni dobra, bodo prevladali odpori in inercija, kar pomeni vztrajanje pri starih načinih dela. Če pa prevladuje mnenje, da je inovacija dobra, potem je njena uvedba odvisna od prepričanj $v$ lastne sposobnosti in zadostnost razpoložljivih virov. $Z$ vplivanjem na spremembo prepričanj vodje dosežejo uvedbo spremembe $v$ treh fazah, od začetnega vztrajanja pri znanih načinih dela preko spodbujanja spremembe do njene uvedbe.

Tudi Holt idr. (2003, 262) opozarjajo na tri ključne faktorje za zmanjševanje odporov pri uvajanju sprememb. Prvega imenujejo primernost in pomeni stopnjo, do katere posamezniki zaznavajo, da se bo sprememba dotaknila poglavitnih organizacijskih potreb. Drugi faktor je percepcija osebnih koristi in šele na tretjem mestu je percepcija podpore formalnih ter neformalnih vodij.

Marinescu (2004, v Angel-Sveda 20I 2, 79) meni, da predstavljajo odpori po eni strani pozitiven fenomen, saj ob spremembah napovedujejo vedenja članov organizacije in ob ustreznem obvladovanju oz. reševanju prispevajo celo k večji stabilnosti v organizaciji. Po drugi strani pa so učinki odporov lahko negativni, saj generirajo konflikte znotraj organizacije.

Nekoliko odpora proti spremembam lahko vedno pričakujemo, saj spreminjajoče se delovne prakse od ljudi zahtevajo dodatne napore in razumljivo je, da želijo vedeti, zakaj bi v spremembo investirali čas in energijo. Managerji, ki se spopadajo z odpori, imajo pri svojem odzivu na izbiro vsaj dve možnosti. Lahko čakajo in upajo, da bodo odpori sčasoma ponehali. Ta opcija na daljši rok običajno prinese še več odporov. Druga možnost pa je, da se z odpori soočijo in jim prisluhnejo. $Z$ aktivnim poslušanjem ter dodatnim pojasnjevanjem jim bo marsikakšen odpor uspelo spremeniti v privrženost spremembi.

\section{Razlogizaneuspeh pri uvajanju sprememb}

$\mathrm{V}$ organizacijah se dogaja, da mnogo pozitivnih sprememb ne uspe. Smith $(2006,300)$ navaja razloge za neuspeh, ki so: (I) pomanjkanje pripravljenosti za spremembo, (2) nezadostno ali neučinkovito načrtovanje, 
(3) napake pri vodenju spremembe, (4) neučinkovita komunikacija in (5) nedokončana sprememba zaradi nezmožnosti doseganja trajnega organizacijskega učenja.

Mauer (20IIb, 17-I8) vidi štiri razloge za neuspeh, ki jih omeni kot napake pri vodenju. Prva napaka je, če vodja razumevanje spremembe pri zaposlenih enači s podporo in zavezo. Vodja najprej predstavi projekt, na katerega pa bodisi ni odzivov bodisi je veliko vprašanj. Nič od tega še ne pomeni odobravanja oz. sprejemanja spremembe. Prepričljiva predstavitev spremembe je zelo pomembna, saj odločilno prispeva k pridobivanju podpore in zaveze sodelavcev za novo iniciativo - to pa je najpomembnejše izhodišče za življenje večine sprememb. Druga napaka je slabo vključevanje zaposlenih v dogovore. Spremembe so zaposlenim v organizacijah velikokrat vsiljene (npr. v imenu krize ipd.). Nevključeni oz. nasprotniki spodkopavajo rezultate, ko npr. razbijajo motivacijo kolegov v delovnem procesu. Tretja napaka je nerazumevanje strahu pred spremembo. Misel na veliko spremembo lahko pri zaposlenih prebudi strah pred izgubo službe. Ljudi skrbi za njihove družine. Osebni strah prevlada nad potrebami organizacije po spreminjanju. Ljudje ne slišijo in ne presojajo trezno. En del ljudi hitreje sprejme spremembo, drugi kasneje. Lahko prihaja do zanikanja, jeze in depresivnega razpoloženja. Vodja mora počakati, da gredo ljudje skozi fazo negativnih čustev. Četrta napaka pa je povezana z zaupanjem, ki lahko spremembo uresniči ali pa jo uniči. Če ljudje vodji zaupajo, mu bodo sledili. Tudi, če naredi napako, jo razumejo, saj je samo človek - še vedno pa mu sledijo.

Paton in McCalman (2000, 50) za zmanjšanje negotovosti pri zaposlenih vodjem predlagata, da:

- identificirajo nosilce interesov in dosežejo njihovo naklonjenost za spremembo;

- postavljajo jasne, razumljive in precizne cilje;

- postavijo natančen načrt spremembe, ki vključuje tudi predvidene težave;

- zgradijo ustrezne kontrolne mehanizme;

- načrtujejo proces sprememb.

Longenecker in Longenecker (2014, I50) sta v svoji raziskavi ugotovila Io ovir, ki preprečujejo uspešne spremembe v bolnišnicah. Predstavljamo jih v preglednici I. Kot najpomembnejšo oviro predstavljata slabo načrtovanje spremembe in nerealne roke, kar že na začetku pri zaposlenih povzroči demotiviranost. Druga ovira je neuspešna začetna iniciativa, ki se kaže v nezadostni komunikaciji oz. informiranju ter nezadostnem 
vključevanju zaposlenih. Mnoge raziskave kažejo, da je na začetku uvajanja zelo pomembno vključevanje zgodnjih zagovornikov oz. podpornikov spremembe, t. i. »change champions « (Branagan 2010, I05; Brown 2012, 25; Chrusciel 2008, 158). To so izjemni strokovnjaki na svojem področju, sodelavci jim zaupajo, istočasno pa verjamejo v uvedeno spremembo. Tretja najpomembnejša ovira pa je pomanjkanje zaupanja v najvišji management, ker se morda že v preteklosti ni izkazal kot učinkovit.

Preglednica I: I o glavnih ovir za uspešne spremembe v bolnišnicah

\begin{tabular}{lc}
\multicolumn{1}{c}{ Ovire } & Delež \\
\hline Slabo načrtovanje s prekratkimi roki. & $73 \%$ \\
\hline Neuspešno ustvarjanje iniciative za spremembo. & $67 \%$ \\
\hline Neučinkovito vodenje in pomanjkanje zaupanja v vršni management. & $62 \%$ \\
\hline Neuspešna priprava realnih planov za izboljšanje procesov. & $55 \%$ \\
\hline Neučinkovita komunikacija od zgoraj navzdol. & $52 \%$ \\
\hline Pomanjkanje fokusa in nejasni cilji. & $50 \%$ \\
\hline Premalo timskega dela in sodelovanja. & $43 \%$ \\
\hline Premalo informiranja o napredku in odgovornosti za akcijo. & $38 \%$ \\
\hline Nejasne vloge, cilji in pričakovan učinek. & $36 \%$ \\
\hline Pomanjkanje časa, virov in podpore vršnega managementa. & $33 \%$ \\
\hline
\end{tabular}

Predstavljene ugotovitve v tej preglednici izhajajo iz vzorca I67 srednjih managerjev iz štirih bolnišnic skupnosti Midwest, ki so sodelovali v 42 fokusnih skupinah, sestavljenih z namenom opredelitve primarnih vzrokov, zakaj pobude za spremembe v bolnišnicah niso dosegle želenih rezultatov. Odstotki se nanašajo na odstotek fokusnih skupin od skupnih 42, ki so ugotovile določen dejavnik.

Vir: Longenecker in Longenecker 2014, 150.

Kee in Newcomer $(2008,5)$ na podlagi svoje dveletne študije uvajanja velikih sprememb $v$ šestih javnih in neprofitnih organizacijah ugotavljata glavne razloge za neuspeh sprememb, ki so: (I) premalo podpore za spremembo ali nerazumevanje odgovornosti; (2) nezadostno razumevanje kompleksnosti spremembe in tveganj, ki jih prinaša; (3) neustrezna vključitev pomembnih deležnikov, ki se jih sprememba dotika; (4) nerazumevanje organizacijske kulture ter $(s)$ nerazumevanje organizacijskih zmožnosti pri uvajanju in vzdrževanju spremembe. Tveganje za neuspelo 


\begin{tabular}{|c|c|c|}
\hline Faktor & Opis & Tveganje \\
\hline \multicolumn{3}{|c|}{ Kompleksnost spremembe } \\
\hline Pomembnost & $\begin{array}{l}\text { Celoten obseg in vpliv sprememb na } \\
\text { organizacijo. }\end{array}$ & $\begin{array}{l}\text { Več ljudi in organizacijskih } \\
\text { subjektov je prizadetih, večje je } \\
\text { tveganje. }\end{array}$ \\
\hline Obseg & $\begin{array}{l}\text { Vpliv na trenutno organizacijsko kulturo, } \\
\text { strukturo, politiko, strategijo in procese. }\end{array}$ & $\begin{array}{l}\text { Globlji je vpliv na organizacijsko } \\
\text { kulturo, strukture, politike, strategije } \\
\text { in procese, večje je tveganje. }\end{array}$ \\
\hline Pretočnost & $\begin{array}{l}\text { Prilagodljivost iniciativ na spreminjajočo se } \\
\text { naravo okolja. }\end{array}$ & $\begin{array}{l}\text { Manj kot je pobuda za spremembe v } \\
\text { okolju prilagodljiva, večje je } \\
\text { tveganje. }\end{array}$ \\
\hline \multicolumn{3}{|c|}{ Deležniki/vpleteni } \\
\hline Zaznavanje & $\begin{array}{l}\text { Zaznana pridobitev ali izguba s strani } \\
\text { notranjih in zunanjih interesnih skupin ter } \\
\text { intenzivnost teh zaznav. }\end{array}$ & $\begin{array}{l}\text { Intenzivneje deležniki dojemajo } \\
\text { svojo potencialno izgubo, večje je } \\
\text { tveganje. }\end{array}$ \\
\hline Raznolikost & $\begin{array}{l}\text { Razpon konceptualizacije organizacijskega } \\
\text { poslanstva, orientacije in svetovnega nazora } \\
\text { v odvisnosti od velikosti ter različnosti } \\
\text { organizacijskih enot in namenov. }\end{array}$ & $\begin{array}{l}\text { Bolj so raznolika organizacijska } \\
\text { stališča in pogledi, večje je tveganje. }\end{array}$ \\
\hline \multicolumn{3}{|c|}{ Socialno-politično okolje } \\
\hline $\begin{array}{l}\text { Pravne in } \\
\text { politične } \\
\text { podlage }\end{array}$ & $\begin{array}{l}\text { Zakoni in drugi predpisi, ki uvajajo } \\
\text { spremembe ali ovirajo spremembe } v \\
\text { poslovanju. }\end{array}$ & $\begin{array}{l}\text { Bolj so toge regulacijske } \\
\text { omejitve, večje je tveganje. }\end{array}$ \\
\hline $\begin{array}{l}\text { Gospodarska } \\
\text { gibanja }\end{array}$ & $\begin{array}{l}\text { Sredstva iz proračuna ali davkov v podporo } \\
\text { pobudam za spremembe. }\end{array}$ & $\begin{array}{l}\text { Ranljivejše je financiranje, večje je } \\
\text { tveganje. }\end{array}$ \\
\hline $\begin{array}{l}\text { Povezava z } \\
\text { zunanjim } \\
\text { okoljem }\end{array}$ & $\begin{array}{l}\text { Državljansko zaupanje ali zahteve za ali } \\
\text { proti spremembam. }\end{array}$ & $\begin{array}{l}\text { Večje je zanimanje javnosti za } \\
\text { spremembe, večje (ali manjše) je } \\
\text { tveganje. }\end{array}$ \\
\hline
\end{tabular}

Slika 6: Faktorji tveganja v javnem sektorju

Vir: Kee in Newcomer 2008, 9.

spremembo prihaja iz treh virov (Kee in Newcomer 2008, 9). Prvi je kompleksnost same spremembe, drugi izvira iz percepcij in raznolikosti vpletenih deležnikov, tretji pa iz družbenopolitičnega okolja. Vse tri faktorje prikazuje slika 6. Sprememba je lahko zelo obsežna, dotika se večine organizacijskih enot ali celotne organizacije. Tveganje za neuspeh je večje, če se sprememba dotika večjega števila organizacijskih enot. Prav tako je tveganje večje, če ima velik vpliv na obstoječo organizacijsko kulturo, poslovno politiko, strukture, strategijo in procese. Pomemben faktor tveganja je dojemanje deležnikov oz. nosilcev različnih interesov, in sicer $\mathrm{v}$ smislu, ali zaznavajo spremembo kot potencialno izgubo ali korist zanje. Veliko tveganje prinaša tudi raznolikost pogledov in stališč deležnikov. Neprofitna organizacija mora upoštevati tudi faktorje socialnopolitične- 
ga okolja, ki lahko s svojimi togimi regulacijskimi omejitvami ali nezadostnim financiranjem pomenijo veliko tveganje pobudam za spremembe. Nazadnje pa so s svojimi zahtevami za ali proti spremembam pomemben faktor tveganja tudi uporabniki storitev oz. širša javnost.

Wittenstein (2008) je raziskoval faktorje pripravljenosti posameznikov za spremembe v ameriških neprofitnih bolnišnicah. Kot ugotavlja (prav tam, 9), so se teorije organizacijskih sprememb mnogo bolj osredotočale na analize spreminjanja na makro nivojih, to so organizacijske značilnosti spreminjanja (vodenje, kultura in okolje), manj pa na značilnosti posameznikov, čeprav spremembe lahko doživijo neuspeh ravno zaradi odporov na individualni ravni (dispozicijski odpori pri posameznikih). Avtor (prav tam, I42) v svoji raziskavi ugotavlja močno korelacijo med čustvenim ozračjem $\mathrm{v}$ organizaciji in dispozicijskimi odpori. Bolj ko zaposleni zaznavajo negativno čustveno ozračje v delovnem okolju, večji so dispozicijski odpori.

\section{Spreminjanje organizacijske kulture}

Uvajanje velikih (radikalnih) sprememb v organizacijah je največkrat povezano s spremembo organizacijske kulture, ki pa jo je zaradi njene trdne pojavnosti praviloma težko spreminjati. Najbolj poznana in največkrat citirana je Scheinova (1992, I2) definicija organizacijske kulture, ki jo opredeljuje kot »vzorec temeljnih domnev, ki jih je skupina iznašla, odkrila ali razvila, ko se je spopadala s problemi eksterne adaptacije in interne integracije «. Domneve se nanašajo na samoumevna vedenja organizacijskih članov do zunanjega okolja in drug do drugega. Vsaka skupina in organizacija na podlagi skupnih izkušenj razvijeta svojo kulturo. Kulturo skupine imenujemo tudi subkultura.

Kakabadse in Kakabadse $(1999,65)$ organizacijsko kulturo opredeljujeta skozi vidike življenja in delovanja, ki se pojavljajo pri interakcijah med zaposlenimi in sčasoma postanejo skupne norme, ki posameznike povezujejo skupaj. To je vzorec dojemanja, mišljenja in čutenja članov organizacije. Pomembne sestavine organizacijske kulture so: vrednote, tipični obrazci vedenja, vzorniki, običaji in obredi, komunikacije ter proizvodi in storitve (Kavčič I99I, 3I). Kultura organizacije je torej definirana $\mathrm{z}$ vedenjskimi normami, tj., kako njeni člani živijo svoje vrednote. Poudarek je na dejanjih in ne zgolj napisanih vrednotah (Rutledge in Sinclair 2013, 69). Kulturo sestavljajo pravila, ki jim sledijo člani organizacije. Ta so lahko eksplicitna (norme) in implicitna, ki niso nikoli izrečena ali napisana, vendar člani organizacije kljub temu delujejo v skladu z njimi (Burke 2002, 206). 
Kultura organizacije je kompleksna in temelji na skupnih pogledih ter prepričanjih zaposlenih, ki so pogosto nezavedna. Stil vodenja pa je ključno gibalo ustvarjanja organizacijske kulture. Kaže se v pretoku informacij, načinu sprejemanja odločitev, metodah motiviranja zaposlenih in načinih razreševanja konfliktov. Organizacijska kultura je pomemben dejavnik, ki spremembe podpira ali pa se jim upira. Manager oz. vodja mora poznati prevladujočo organizacijsko kulturo in jo po potrebi tudi spreminjati. Yukl $(1998,333)$ pravi, da je v času stabilnosti in prosperitete organizacije treba krepiti obstoječo kulturo, da se obdrži konsistentnost $s$ strategijo. Implementiranje večjih sprememb pa zahteva vsaj določeno modifikacijo organizacijske kulture. Ena pot za vpliv na kulturo je sprememba oblik, npr. simbolov, sloganov in ritualov (Yukl 1998, 334). Zelo težko je, npr., narediti spremembe $\mathrm{v}$ strategiji, če te niso kompatibilne $\mathrm{z}$ obstoječo kulturo, za razliko od tistih, ki gradijo na obstoječih vrednotah in domnevah.

Pri spreminjanju kulture se je potrebno osredotočiti na nove, želene oblike ravnanja. Schein $(2008,2$ I) predlaga tri glavna področja osredotočenja. Treba je ugotoviti, kako bo novo ravnanje koristilo pri reševanju obstoječih problemov. Če je želeno ravnanje skladno z domnevami, kulture ni treba spreminjati, če pa želeno ravnanje ovirajo določene kulturne domneve, jih moramo spremeniti. Najprej moramo ugotoviti, kateri konkretni element kulture je treba spreminjati, potem pa se osredotočiti na želeno ravnanje in ga vedno znova uveljavljati. Novo ravnanje podpremo z ustreznim nagrajevanjem in discipliniranjem.

Četudi je spreminjanje kulture tek na dolge proge, je včasih treba »zagristi v to kislo jabolko «, kar v končni fazi omogoča implementacijo potrebnih sprememb.

\section{Vrste sprememb v organizacijah}

Vse organizacijske spremembe po svoji naravi niso enake. Različni avtorji različno opredeljujejo oz. ločujejo različne vrste sprememb. Golembiewski, Billingsley in Yeager (1976, v Roach in Bednar 1997, 69I) predstavljajo koncept treh tipov sprememb kot rezultat razvoja organizacije (angl. organizational development).

- Alfa spremembe: gre za spremembe neke trdne dimenzije v organizacijskem sistemu (npr. aktualnih procesov), ki jih je možno meriti pred spremembo in po njej. 
- Beta spremembe: gre za spremembe nekih subjektivnih (mehkih) dimenzij organizacijskega sistema, pri katerih se napredka ne da jasno izmeriti.

- Gama spremembe: gre za korenite spremembe vseh dimenzij organizacijskega sistema.

Možina idr. (1994, 852) po vsebini spremembe ločujejo na operativne in strateške, po obsegu pa na delne in celovite, pri čemer optimiranje poslovnih procesov obravnavajo kot delno strateško spremembo, prestrukturiranje pa kot celovito strateško spremembo, optimiranje poslovnih dejavnosti uvrščajo med delne operativne spremembe, reorganizacijo pa med celovite operativne spremembe.

Ackerman Anderson in Anderson (20II, 3I) ločujeta 3 vrste sprememb:

- razvojne: predstavljajo stalno izboljševanje načinov dela (procesov in veščin);

- tranzicijske oz. prehodne: pomenijo zamenjavo starih načinov dela z novimi, toda znanimi;

- transformacijske: radikalne spremembe struktur, procesov, kulture in strategije; običajno sledijo seriji tranzicijskih sprememb.

Burke (2002, 63-74) spremembe deli na transformacijske in transakcijske. Prve so radikalne, korenite spremembe, ki zahtevajo temeljito preobrazbo potekov dela znotraj organizacije. Pojavljajo se kot enkratno odzivanje na revolucionarne spremembe v okolju. Običajno sledijo nizu transakcijskih sprememb. Transakcijske spremembe (postopne, inkrementalne) v praksi pomenijo nenehno izboljševanje vseh pristopov oz. potekov dela in so odziv na evolucijske spremembe v okolju. Transformacijske spremembe so redkejše, transakcijske spremembe pa se v organizacijah pojavljajo pogosteje.

Porras in Robertson (1992, v Burke 2002, I29-131) delita spremembe na načrtovane in nenačrtovane ter na spremembe prvega in drugega reda. Med spremembe prvega reda avtorja (prav tam) uvrščata nenehno izboljševanje obstoječega stanja, med spremembe drugega reda pa revolucionarne oz. radikalne spremembe. Hersey in Blanchard (1993, 37I) spremembe prvega reda opisujeta kot kontinuirane spremembe, ki se pojavljajo $\mathrm{v}$ stabilnem sistemu, ki sam po sebi ostaja nespremenjen. Spremembe drugega reda pa so nekontinuirane spremembe, ki pretresejo obstoječe procedure in strukture ter običajno povzročijo destabilizacijo obstoječega sistema. 
Zanimiv prikaz v zvezi s spremembami prispeva Pennington (2003, 6). Avtor trdi, da so majhne spremembe, ki nastajajo v organizacijskem okolju skozi evolucijsko rast, hitro absorbirane in so pogosto opisane kot rast, razvoj, napredek ter učenje. V delovno okolje so absorbirane na organski, naraven način in so zaznane kot pozitivne ter stimulativne. Pennington $(2003,4)$ pravi, da se mnoge spremembe porajajo kot posledica tekmovalnih političnih iniciativ. Umešča jih na dve skali, katerih skrajnosti predstavljata radikalna oz. inkrementalna sprememba ter temeljna oz. obrobna sprememba. Slika 7 prikazuje opisano dvodimenzionalno matriko. Radikalne spremembe temeljnih dejavnosti v celotni organizaciji ali oddelku povzročajo visoko stopnjo motenj in visoko tveganje (da spremembe ne uspejo), inkrementalne spremembe obrobnih aktivnosti pa so zaznane kot nekaj običajnega, samo po sebi umevnega (z nizko stopnjo povzročenih motenj in nizko stopnjo tveganja).

\begin{tabular}{c|c|c}
\multicolumn{2}{c}{ Radikalne } \\
\multirow{4}{*}{ Visoka motnja } & $\begin{array}{c}\text { Zmerna motnja } \\
\text { Nižje tveganje }\end{array}$ & Periferne \\
\cline { 2 - 3 } Visoko tveganje & Nizka motnja & \\
\cline { 2 - 3 } & Zmerna motnja & Nizko tveganje
\end{tabular}

Inkrementalne

Slika 7: Vrste sprememb

Vir: Pennington 2003, 6.

Hussey (1995, 13) obravnava dva tipa sprememb: inkrementalno in fundamentalno. Meni, da je inkrementalna sprememba v svojem dolgoročnem vplivu na ljudi marginalnega pomena. Vedno je samoumevna in povezana z mnogimi situacijami, s katerimi se managerji dnevno soočajo. Vključuje spremembe metod dela in procesov, vpeljevanje novih proizvodov, skratka stvari, ki bi jih večina članov organizacije prepoznala kot kontinuiteto iz starega stanja v novo stanje. Napreduje počasi z evolucijo, ne pa z revolucijo, in čeprav bi opazovalec po dolgem času videl veliko razliko med organizacijo $\mathrm{v}$ preteklosti in organizacijo danes, pa nobena sprememba sama zase ni pomenila velike razlike, povedano drugače, organizacija je ni čutila. Nikakor pa to ne pomeni, da so inkrementalne spremembe za izvajanje lahke in da ne prihaja do odporov.

Fundamentalno (temeljno) spremembo avtor (prav tam) poimenuje tudi strateška, vizionarska in transformacijska. Povzroči občuten vpliv na 
organizacijo ali na del organizacije, v kateri poteka. Če je uspešna, je razlika očitna tako znotraj kot zunaj organizacije. Če pa je neuspešna, povzroči mnogo več »bolečine «, ker so posledice za organizacijo hujše. To so običajno velike spremembe, ki dramatično vplivajo na prihodnje delovanje organizacije, kot so npr. združitve $\mathrm{z}$ drugo organizacijo, drastično zmanjševanje števila zaposlenih ali uvedba popolnoma novih dejavnosti. Vse fundamentalne spremembe so pomembne, medtem ko so inkrementalne nujne, pomembne pa le do neke mere.

\section{Vodenje sprememb $v$ zdravstvenih organizacijah}

Ob številnih spremembah, ki se dogajajo v zdravstvenih organizacijah, ni presenetljivo, da te predstavljajo velik izziv zanje in neposredno za management. Poleg tega morajo vodstva bolnišnic upoštevati tudi profesionalno avtonomijo zdravnikov (Kuhlmann idr. 2013, 2). Kot ugotavljajo avtorji (prav tam) primerjalne študije med bolnišnicami v sedmih evropskih državah, morajo bolnišnice prvenstveno skrbeti za obvladovanje stroškov in kakovosti svojih storitev, kar je lahko popolnoma integrirano v celotno delovanje bolnišnice. Lahko je delno integrirano ali celo razdrobljeno, če ima nadzor nad stroški management, nadzor nad kakovostjo pa medicinska oz. zdravstvena stroka. Integracija obvladovanja obeh področij je ena bistvenih sprememb oz. izboljšav, ki se v zadnjih letih dogajajo na nivoju evropskega zdravstva. Problem nepopolne integracije obeh področij v delovanje bolnišnice je po našem mnenju med ostalim lahko tudi posledica dvojnosti vlog, v katerih nastopajo zdravniški vodje in so jih nekateri avtorji (Chapman, Johnson in Kilner 2014, 286) opredelili kot:

- prvo vlogo: vodilni klinik, odgovoren za delo svojega strokovnega tima;

- drugo vlogo: del managerske strukture $\mathrm{v}$ zdravstveni organizaciji.

Trastek, Hamilton in Niles $(2014,374)$ prisegajo na model vodenja $\mathrm{v}$ zdravstvu, ki se osredotoča na moč tima, razvija zaupanje in služi potrebam pacientov. Skela Savič in Pagon $(2007,72)$ v svoji raziskavi prav tako ugotavljata močno povezanost med timskim delom in uspešnim izvajanjem sprememb v slovenskih bolnišnicah. Tomlinson (20 I 2, 34) je v svoji kvalitativni raziskavi ugotavljala, kakšen učinek imajo različni stili vodenja vodilnih medicinskih sester na delovne time v kliničnem okolju. Rezultati so pokazali, da so $\mathrm{v}$ primerih transformacijskega vodenja $\mathrm{v}$ kombinaciji s porazdeljenim vodenjem (angl. distributed leadership) in večjo vključenostjo tima zaposleni bolj osredotočeni na pacienta in v več- 
ji meri dosegajo organizacijske cilje. Po njenem videnju morajo vodje za doseganje uspešnosti pri uvajanju sprememb razvijati transformacijski stil vodenja. DaCosta $(2012,577)$ pa ugotavlja, da je zaradi spreminjajočega se okolja $\mathrm{v}$ zdravstvu potrebno razvijati tako transakcijsko kot transformacijsko vodenje. Xirasagar, Samuels in Stoskopf (2005, 732) v svoji raziskavi ugotavljajo značilno povezanost med transformacijskim vodenjem in učinkovitostjo v doseganju organizacijskih sprememb. Njihova empirična študija potrjuje, da imajo zdravniški vodje s transformacijskim načinom vodenja značilen vpliv na vedenje zaposlenih, ki v delo vlagajo večje napore in trud.

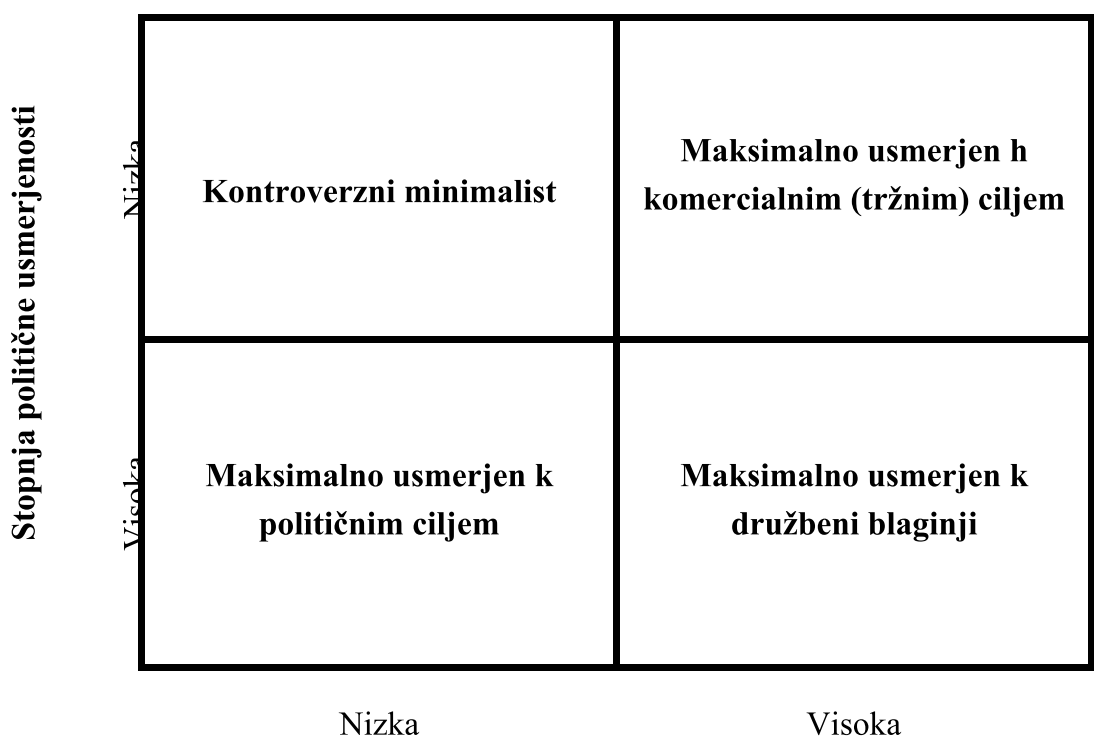

Stopnja poslovne usmerjenosti

Slika 8: Tipologija vodstvenih stilov

Vir: Goodwin 2006,67.

Goodwin $(2006,64)$ trdi, da bi moral uspešen vodja v zdravstveni ustanovi posvečati več pozornosti managementu kot tudi vodenju. Avtor prikazuje 4-dimenzionalno tipologijo vodstvenih stilov (slika 8), ki temelji na mednarodni raziskavi in kaže, kako naj manager $\mathrm{v}$ javnem zdravstvu krmari med političnimi in managerskimi pritiski. Idealni model vodenja je tisti, pri katerem sta pri vodji izraženi visoka stopnja poslovne usmerjenosti in visoka stopnja politične usmerjenosti. Po Goodwinu $(2006,67)$ predstavlja osmišljanje reform in sprememb največji izziv vodenja v zdra- 
vstvu, čeprav je vodja pri uvedbi teh sprememb vpet med politično določenimi reformami in odpori strokovnega osebja, brez katerega pa ni mogoče implementirati spremembe.

Siverbo, Eriksson in Wijk (2013, 166) obetavno pot za spremembe v zdravstvu vidijo skozi pristop opolnomočenja zaposlenih. Budak in Kar (2014, I66) trdita, da mora imeti zdravstvena ustanova, če želi biti uspešna, vodje, ki razumejo zunanje okolje in znajo zgraditi učinkovite strategije za obvladovanje sprememb. Ob prizadevanjih za zadostitev političnih in poslovnih zahtev pa se poraja vprašanje, $\mathrm{v}$ kolikšni meri zdravstveni managerji razumejo človeški faktor.

Gyllstrom idr. (2015, 315) v svoji študiji ugotavljajo, da večja zrelost oz. pripravljenost zdravstvene organizacije za stalno izboljševanje kakovosti povečuje njene zmožnosti za izvajanje radikalnih sprememb, ki jih avtorji opredeljujejo kot spremembe večjega obsega. Organizacijsko zrelost za izboljševanje kakovosti (angl. Quality Improvement Maturity) avtorji omenjene študije (prav tam, 3 I I ) definirajo kot celovit koncept, ki se odraža v organizacijski kulturi, organizacijskih zmožnostih in usmerjanju k sistematičnim prizadevanjem za izboljšave.

Caldwell, Butler in Poston (2010, 6) so raziskali razlike med uspešnimi in manj uspešnimi vodilnimi zdravstvenimi managerji med uvajanjem sprememb, ki so bile vezane na zmanjševanje stroškov, istočasno pa so potekale tudi druge spremembe, kot so akreditacija bolnišnic, vpeljava novih informacijskih sistemov, aktivnosti, vezane na izboljšanje kliničnih storitev idr. Po njihovih ugotovitvah obstajajo močne razlike $\mathrm{v}$ kompetencah vodilnega tima, vendar vodenje vršnega nivoja samo po sebi ni najključnejše, temveč je potrebno po njihovem mnenju upoštevati tudi faktorje, kot so struktura, postavljanje prioritet, uporaba podatkov in organizacijska kultura. Avtorji (prav tam, 6-7) pri manj uspešnih implementatorjih sprememb ugotavljajo naslednje značilnosti:

- preveč posvečanja pozornosti analizi in premalo implementaci$\mathrm{ji}, \mathrm{s}$ čimer povzročajo zamude pri implementaciji; na ta način še najbolj zagnani zaposleni postanejo frustrirani in izgubijo potrebno energijo ter zagon za spremembe;

- $\quad$ strah pred spremembo, ki se pri neuspešnih pojavlja v večji meri; tudi uspešni se soočajo s strahom, vendar mu ne dovolijo, da jim stoji na poti in jim preprečuje napredovanje; pogosto izraženi razlogi za zamude pri uvedbi sprememb so: strah nadzornikov ali javnosti ter strah pred nezadostnim znanjem;

- prepričanje, da časovni okvir sprememb ni pravi, ker dajejo prednost drugim prioritetam, uspešni pa so sposobni uravnovešati 
različne prioritete, pri čemer zaposlene usmerjajo v različne aktivnosti, ki jih narekujejo te prioritete;

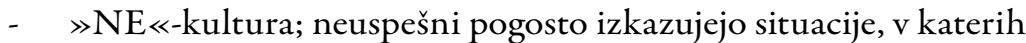
ima vsakdo pravico reči $\gg$ ne $\ll$ in nobeden $\gg$ da $\ll-$ to še posebej velja za akademske organizacije;

- $\quad$ prepričanost v rešitve »od zunaj《, npr. zagotovitev več sredstev.

Caldwell, Butler in Poston (2010, 7-II) v raziskavi izluščijo tudi nekatere značilnosti najuspešnejših implementatorjev sprememb.

- Hitrost vidijo kot konkurenčno prednost. So hitri pri postavljanju ciljev na osnovi razpoložljivih podatkov in ne zgubljajo časa z zbiranjem vedno novih in novih podatkov za (velikokrat nepotrebne) analize. Prav tako ne zgubljajo časa s številnimi in nepotrebnimi sestanki. Postavijo merljive cilje, s katerimi potem merijo svoj uspeh. Niso privrženci situacij »status quo «, ampak nove ideje pilijo, dokler ne postanejo sprejemljive za realizacijo. - Gradijo kulturo odgovornosti, ki temelji na medsebojnem zaupanju in spoštovanju. Ne kritizirajo, če pa že, potem konstruktivno. Osredotočajo se na pozitivne vidike idej, načrtov ipd. Razvijajo mehanizme, ki omogočajo sodelovanje med različnimi oddelki. V tem se razlikujejo od neuspešnih, ki nesodelovanje med različnimi oddelki izpostavijo kot pomembno opravičilo za neuspeh. Managerji srednjega nivoja so dobro usposobljeni za uvajanje sprememb, obvladajo veščine agentov sprememb.

Vodenje (voditeljstvo), ki je vezano na odnose, je v tesni povezavi z vplivanjem na zaposlene. Verle in Markič (2012, 42) kot glavni težavi pri procesu sprememb zaznavata odsotnost aktivne pomoči nadrejenih in odsotnost močnega vodstva. Sprašujemo pa se, ali so zaposleni v procesu spreminjanja »prevozno sredstvo《 ali ovira na poti do uspešne in učinkovite uvedbe spremembe. Smith (2005, 153) zaposlene pri uspešnem doseganju začrtanih sprememb po eni strani vidi kot glavno oviro, po drugi strani pa kot ključen faktor za dosego trajnih sprememb. Adizes (1996, I58) pravi, da lahko vodja organizacijo spreminja tako, da najprej ustvari zaupanje in spoštovanje. Pred tem pa je potrebno spremeniti organizacijsko strukturo in način odločanja. Proces naj se spreminja v smeri soodločanja (Adizes 1996, I 87). Pardo del Val, Martinez-Fuentes in Roig-Dobon (20I 2, 85 I) v svoji raziskavi ugotavljajo, da participativni management, ki se nanaša na vključevanje zaposlenih v odločanje, ne zmanjšuje odporov proti spremembam in ne prispeva $\mathrm{k}$ uspešnosti uvedene spremembe, kar je v nasprotju s spoznanji mnogih teoretikov. O’Neil in Morjikian (2003, 
178) v procesu spreminjanja ključni pomen pripisujeta uporabi različnih stilov vodenja, katere namen je motivirati in navdihovati zaposlene, da se začrtana strategija $\mathrm{v}$ povezavi s spremembami v praksi tudi uresniči. Dimovski idr. (2005, 23I) na podlagi preučitve raziskav trdijo, da so nekateri vodstveni slogi pri uvajanju sprememb učinkovitejši, zato morajo današnji vodje izkoristiti posebna znanja, spretnosti in sposobnosti vsakega zaposlenega ter spodbujati njihov interes, pobude, razprave in stalno učenje. To še posebej velja za t. i. znanjske delavce, tj. visoko usposobljen strokovni kader. Tudi po trditvah Biloslava $(2004,74)$ je prav vodenje zaposlenih (predvsem vizija in motivacija) tista značilnost, ki ji je potrebno posvečati največ pozornosti. 



\section{Teorije in stili vodenja}

V tem poglavju smo iz nepregledne množice literature in raziskav s področja vodenja izluščili najpomembnejše teorije in opredelitve stilov vodenja, relevantnih z vidika naše raziskave. Prikazali bomo teorije osebnih značilnosti, vedenjske in situacijske modele, transakcijsko, transformacijsko in vodenje laissez-faire vodenje ter avtentično vodenje. Dotaknili se bomo kompetenc vodij in pomena čustvene inteligence $\mathrm{v}$ vodenju.

Fenomen vodenja je zaradi svoje svojevrstne narave vedno predstavljal velik izziv praktikom in bil velik raziskovalni interes mnogih teoretikov. Skozi zgodovino so nastajale mnoge teorije, razviti so bili številni modeli in stili vodenja.

Stil vodenja lahko opredelimo kot relativno trajen vzorec vplivanja vodje na zaposlene (Kovač, Mayer in Jesenko 2004, 22), ki je značilen za posameznega vodjo in vezan na njegova specifična vedenja in ravnanja. $\mathrm{Na}$ osnovi preučevanja uspešnih stilov vodenja v praksi so nastajale različne teorije in pristopi, kar dokazuje, da je vodenje kompleksen proces in ga je težko obravnavati z vidika ene same teorije.

Yukl (1998) je spoznanja raziskovalcev s področja vodenja razvrstil v pet značilnih modelov oz. pristopov: teorijo osebnih značilnosti, vedenjske teorije, pristope z vidika moči in vpliva, situacijske teorije in integrirane modele, kamor uvršča karizmatično, transakcijsko in transformacijsko vodenje.

Prvi sistematični poskus raziskovanja vodenja sega na začetek 20. stoletja. Teorija osebnih značilnosti (Trait Theory) je prva poskušala določiti, kateri dejavnik naredi iz človeka velikega vodjo. 


\section{Teorija osebnih značilnosti}

Teorija osebnih značilnosti sodi med najstarejše teorije in izhaja iz predpostavke, da se dobri vodje rodijo. Ko jih organizacija potrebuje, jih mora le identificirati med zaposlenimi. Tovrstna teoretična razmišljanja se pojavljajo od leta 1940 dalje (Turner in Müller 2005, 50). Raziskovalci v tistem obdobju so verjeli, da imajo vodje neke prirojene izjemne značilnosti, s katerimi lahko uspešno opravljajo vodstveno funkcijo. Skoraj 45 let so raziskovalci ugotavljali značilnosti uspešnih vodij (Bass I990, 59). Izluščili so pomembne in jih uvrstili v štiri sklope (Možina idr. 2002, 517 ): telesne (starost, videz, vitalnost), osebnostne (stabilnost, samozavestnost, prilagodljivost), socialne (izobrazba, olikanost) in delovne (iniciativnost, delavnost, odgovornost). Preglednica 2 kaže povzetek osebnostnih lastnosti in karakteristik, ki so jih identificirali raziskovalci tega pristopa.

Teorije osebnih značilnosti identificirajo tri kategorije značilnosti, ki vodjem pomagajo pri njihovi uspešnosti. To so: motivacija, osebnost in zmožnosti (Elmuti, Minnis in Abebe 2005, 1020). Med osebnostne značilnosti prištevajo poleg drugih tudi nivo energije vodje, njegovo toleranco na stres, samozavest in čustveno zrelost. Med motivacijskimi dejavniki pa je pomembna močna potreba po dosežkih oz. doseganju rezultatov.

Preglednica 2: Raziskave osebnih značilnosti in karakteristik vodij

\begin{tabular}{|c|c|c|c|c|}
\hline $\begin{array}{l}\text { Stogdill } \\
(1948)\end{array}$ & $\begin{array}{l}\text { Mann } \\
(1959)\end{array}$ & $\begin{array}{l}\text { Stogdill } \\
\text { (1974) }\end{array}$ & $\begin{array}{l}\text { Lord, DeVader } \\
\text { in Alliger } \\
\text { (1986) }\end{array}$ & $\begin{array}{l}\text { Kirkpatrick Locke } \\
\text { (1991) }\end{array}$ \\
\hline Inteligenca & Inteligenca & Dosežki & Inteligenca & Delovni elan \\
\hline $\begin{array}{l}\text { čuječnost } \\
\text { vpogled } \\
\text { odgovornost } \\
\text { iniciativnost } \\
\text { vztrajnost } \\
\text { samozaupanje } \\
\text { družabnost }\end{array}$ & $\begin{array}{l}\text { možatost } \\
\text { ciljna naravnanost } \\
\text { dominantnost } \\
\text { ekstrovertiranost } \\
\text { konservativnost }\end{array}$ & $\begin{array}{l}\text { vztrajnost } \\
\text { vpogled } \\
\text { iniciativnost } \\
\text { samozaupanje } \\
\text { odgovornost } \\
\text { kooperativnost } \\
\text { tolerantnost } \\
\text { vplivnost } \\
\text { družabnost }\end{array}$ & $\begin{array}{l}\text { možatost } \\
\text { dominantnost }\end{array}$ & $\begin{array}{l}\text { motiviranost } \\
\text { integriteta } \\
\text { zaupanje } \\
\text { kognitivne sposob- } \\
\text { nosti } \\
\text { znanje za opravljan- } \\
\text { je nalog }\end{array}$ \\
\hline
\end{tabular}

Vir: Northouse 2001, I8.

Konceptualizacija vodenja $\mathrm{z}$ vidika osebnih značilnosti vodij ima določene pomanjkljivosti. Predvsem je iz množice značilnosti in karakteristik vodij nemogoče določiti najpomembnejše, ki bi prispevale $k$ uspešnemu vodenju. Prav tako je nemogoče, da ima posameznik vse zahtevane 
lastnosti idealnega vodje. $V$ zadnjih sto letih je bilo narejenih mnogo študij na temo osebnih značilnosti in karakteristik vodij, vendar so rezultati dvoumni in včasih tudi negotovi (Northouse 2001, 22). V teorijo o vodenju pa so teorije osebnih značilnosti prispevale nekaj koristnih dognanj. Rdeča nit $\mathrm{v}$ mnogih raziskavah je ugotovitev nekaterih skupnih značilnosti vodij, ki jih povzemamo spodaj.

- Inteligenca: verbalne sposobnosti in sposobnosti dojemanja so pri vodenju zelo v pomoč, vendar pa vodjeve inteligenčne sposobnosti ne smejo od podrejenih preveč odstopati. Raziskave so pokazale, da imajo lahko vodje z visokimi sposobnostmi (IQ) težave pri komunikaciji, predvsem zaradi tega, ker so zaradi svojih naprednih idej težko razumljivi in sprejeti s strani podrejenih.

- Samozaupanje: je zmožnost, da vodja verjame v svoje sposobnosti oz. kompetence. Vodenje vključuje vplivanje na druge, zato ta značilnost pomeni prepričanje vodje, da so njegovi poskusi vplivanja na podrejene primerni in pravi.

- Odločnost: je v povezavi z vodjevo željo, da je delo narejeno. Vključuje iniciativnost, vztrajnost, dominantnost in delovni elan. Posamezniki s to lastnostjo so proaktivni in se znajo soočati z ovirami. Odločnost občasno vključuje tudi dominantnost, predvsem ko je treba zaposlene usmerjati v pravo smer.

- Integriteta: pomeni biti pošten in zaupanja vreden. Vodja, ki ga odlikuje integriteta, $v$ podrejenih vzbuja zaupanje, ker vedno stori tisto, kar reče.

- Družabnost: je sposobnost vodje, da gradi prijetne odnose na podlagi prijateljstva, taktičnosti in diplomacije. Vodja je občutljiv za potrebe drugih in kaže skrb za njihovo dobro. Ima dobro razvite medosebne veščine in vzpostavlja kooperativne odnose.

Mnogo avtorjev pripisuje velik pomen integriteti in kredibilnosti (Bass 1990, 243; Covey 2000, 35; Mesiti 2003, 109; Storr 2004, 417), spet drugi vidijo vodjeve kvalitete $\mathrm{v}$ praktičnosti, entuziazmu, samodisciplini, ekstrovertiranosti in mirnosti (Belbin 1993, 53). Med pomembne lastnosti v težkih časih nenehnih sprememb Charan (2009, 24-26) uvršča: poštenost vodje, sposobnost navdihovanja, občutek za realnost $s$ kančkom optimizma ter globoko osebno vpetost $\mathrm{v}$ različne aktivnosti organizacije. Pri vodenju so nekatere kvalitete vodij zelo pomembne, vendar pa Adair ( 1998,13$)$ pravi, da osebnostne lastnosti in karakter posameznika še zdaleč ne zadoščajo za uspešno vodenje. 
Stanley $(2006,26)$ je raziskoval kvalitete in karakteristike kliničnih vodij v zdravstveni negi. Preglednica 3 prikazuje 42 značilnosti, ki jih je izluščil iz obstoječe teorije, preglednica 4 pa prikazuje te značilnosti rangirane po pomembnosti.

\section{Preglednica 3: Lastnosti in značilnosti kliničnih vodij}

\begin{tabular}{lll}
\hline Obvladuje spremembe & Motivator & Obvlada rutino \\
Določa smer & Nadzornik & Konsistenten \\
Ceni odnose & Usmerjaljudi & Obvladuje kompleksnost \\
Je fleksibilen & Učitelj & Viden \\
Vodi & Mentor & Vizionarski \\
Postavlja cilje & Pogajalec & Usmerja/pomaga \\
Je kredibilen (integriteta) & Dolžnost/odgovornost & Nagrajuje/ kaznuje \\
Navdihovalen & Premišljen & Managerske izkušnje \\
Kritičen mislec & Urejevalec & Gradi na zaupanju \\
Ustvarjalen/inovativen & Analitičen & Alociranje virov \\
Klinične kompetence & Administrator & Vzdrževanje \\
Umetniški & Konservativen & Vzbuja zaupanje \\
Podpirajoč & Zagovornik & Dober govorec \\
Dostopen & Povzročitelj sprememb & Pravičen \\
\hline
\end{tabular}

Vir: povzeto po Stanley 2006, 26.

Preglednica 4: Lastnosti in značilnosti kliničnih vodij - rangirane po pomembnosti

\section{Najbolj pomembne}

Manj pomembne

Dostopen $(97.3 \%)$

Klinične kompetence $(95,2 \%)$

Motivator $(94, \mathrm{I} \%)$

Podpirajoč $(94, \mathrm{I} \%)$

Vzbuja zaupanje (93.0\%)

Obvladuje spremembe $(90,9 \%)$

Je fleksibilen $(90,4 \%)$

Določa smer $(89,3 \%)$

Usmerja/pomaga $(88,8 \%)$

Je kredibilen (integriteta) ( $82,2 \%)$
Nadzornik (78,i \%)

Umetniški (65,9\%)

Konservativen $(62,2 \%)$

Obvlada rutino $(57,4 \%)$

Premišljen (47,3\%)

Nagrajuje/kaznuje (39.3\%)

Administrator $(33,5 \%)$

Urejevalec $(32,4 \%)$

Usmerja ljudi 27,I \%)

Vzdrževanje (25,0\%)

Vir: povzeto po Stanley 2006, 27.

Teorije osebnih značilnosti so preživele mnoge kritike. Danes vemo, da se vodja ne samo rodi, temveč se tudi razvija. Za lasten razvoj v smeri vodstvenih kompetenc mora biti močno motiviran in pripravljen na najzahtevnejše delo, tj. delo na samem sebi oz. na spreminjanju sebe. 


\section{Vodenje in kompetence}

V zadnjem obdobju, predvsem po letu I990, teorije osebnih značilnosti vse bolj nadomešča ugotavljanje kompetenc. Turner in Müller (2005, 53) navajata, da različne kombinacije kompetenc lahko pomenijo različne stile vodenja, primerne za različne situacije - transakcijsko vodenje za manj kompleksne situacije in transformacijsko vodenje za zelo kompleksne situacije. Oba načina vodenja sta opisana v razdelkih 3.5 in 3.6.

Bass $(1990,97)$ poudarja, da so kompetence za delo in inteligenca vodij zelo pomembne za vodenje. Med najpomembnejšimi kompetencami, ki so bile tema raziskav mnogih raziskovalcev, avtor (Bass 1990, I I0-I7) izpostavlja predvsem medosebne veščine, kot so komunikacija, avtentičnost in zaupanje ter zmožnost reševanja konfliktov. Po Yuklu (1998, 24I) kompetence vključujejo osebnostne lastnosti, motive, kognitivne in interpersonalne veščine. Tudi Majcen (2009, 21) obravnava kompetence kot posamezne lastnosti, značilnosti, znanja in sposobnosti, ki so potrebne za delo.

Verle in Markič (2012, 85) med kompetence vodij oz. managerjev uvrščata znanje, sposobnosti, veščine, osebnostne lastnosti, vedenja, vrednote ter motivacijo. Avtorja (2012,45) ugotavljata, da uspešnost (predvsem zdravstvenih organizacij) ne določajo le finančni kazalniki. Enako pomembni so tudi humani odnosi med zaposlenimi, osmišljanje lastnega dela ter zadovoljstvo zaposlenih. Manager mora graditi most med tehničnim in socialnim delom organizacije. V svoji raziskavi Verle in Markič (2012, 173) ugotavljata, da organizacije s sodobnimi oblikami organiziranosti, kot je npr. procesna in matrična oblika organiziranosti, zahtevajo managerje $z$ razvitimi mehkimi veščinami. Navajata predvsem socialne in vodstvene kompetence (komunikativnost, empatijo, sposobnost poslušanja, timsko delo, fleksibilnost, močno voljo, kreativnost) ter akcijske kompetence (sposobnost sprejemati izzive, odgovornost in sposobnost doseganja ciljev).

Dulewicz in Higgs (2005, 106) prav tako ugotavljata, da ima osebnost vodje pomembno vlogo pri vodenju. Izpostavljata naslednje pomembne osebne karakteristike vodij:

- $\quad$ avtentičnost: biti originalen oz. $\gg s v o j \ll$ in ne poskušati posnemati nekoga drugega na manipulativen način;

- integriteta: biti konsistenten oz. delati isto kot govoriti;

- volja: po vodenju in vztrajnost pri doseganju ciljev;

- prepričanost vase: realna ocena svojih zmožnosti in prepričanje, da lahko dosežeš zastavljene cilje; 
- samozavedanje: realno razumevanje, $\gg k d o$ si«, kako čutiš in kako te vidijo drugi.

Avtorja (prav tam) pri vodenju poudarjata pomen nekaterih kompetenc, kot so:

- predvidevanje: zmožnost videti jasno sliko prihodnosti, ki bo usmerjala prizadevanja zaposlenih in izkoristila njihove veščine;

- vključevanje: najti ustrezen način za vsakega posameznika, da razume vizijo in najbolje prispeva $\mathrm{k}$ njeni uresničitvi;

- omogočanje: verjeti $v$ talente in potenciale posameznikov ter ustvarjati okolje, kjer se ti lahko sproščajo;

- poizvedovanje: biti odprt za resničen dialog z vsemi vključenimi v organizacijo in spodbujati odprto ter odkrito debato glede vseh tem;

- razvijanje: delati z ljudmi, da razvijajo svoje zmožnosti, in jim pomagati, da prispevajo po svojih najboljših močeh.

Bowen $(2015,34)$ ugotavlja, da so določene tradicionalne veščine vršnih zdravstvenih managerjev, kot je npr. obvladovanje financ, nujno potrebne, vendar za obvladovanje spreminjajoče se zdravstvene dinamike ne zadoščajo več. Meni (prav tam), da se pojavljajo premiki paradigme na vseh nivojih zdravstva, in sicer:

- osredotočenost: povezana s premiki od skrbi za zdravje posameznega pacienta k zdravju skupnosti oz. družbe;

- organizacijski cilji: premiki od zdravljenja posamezne bolezni $\mathrm{k}$ doseganju dobre zdravstvene kondicije prebivalstva;

- nagrade: $v$ preteklosti vezane na količino, postajajo vse bolj vezane na vrednote in rezultate;

- okolje: ni vezano zgolj na institucije, temveč tudi na skupnost;

- vodstvene zmožnosti: v preteklosti vezane na vodenje oddelkov, danes pa se od vodij zahteva sistemsko razmišljanje in integriranje procesov ter učenje, kaj deluje in kaj ne, ter na osnovi tega uveljavljanje najboljših praks.

ACHE (American College of Healthcare Executives) je identificiral pet kompetenc, ki bi jih vršni managerji morali obvladati pri vodenju današnjih zdravstvenih organizacij (Bowen 2015, 34). Naštevamo jih spodaj.

- Vizionarsko in prilagodljivo vodenje: vršni managerji s to kompetenco so vodje, ki načrtujejo in delujejo v skladu z vizijo. Pri tem 
upoštevajo trenutne in prihodnje možnosti organizacije ter svoje time navdihujejo za rast in delovanje v spreminjajočem se okolju. Kvalitete takšnega voditelja so: odprtost, domišljija, vztrajnost, prepričanje in zmožnost voditi proces spreminjanja v skladu $\mathrm{z}$ začrtanimi nameni.

- Zmožnost zgraditi lojalnost in zaupanje: to je veščina, ki se dandanes zahteva od vršnih managerjev. Poleg upravljanja z odnosi znotraj organizacije morajo transformacijski vodje zgraditi lojalnost in zaupanje tudi izven meja svojih organizacij, včasih celo izven zdravstvenega področja. Razvijati morajo strateške povezave in zavezništva. Predvsem pri vodenju sprememb je ključnega pomena, da znajo svojo vizijo navdihovati izven lastnih organizacij.

- Samoobvladovanje: transformacijski vodje morajo znati opazovati, razumeti, nadzirati ter razumeti lastna čustva, prav tako tudi čustva drugih. Prav ta t. i. čustvena inteligenca omogoča vodjem, da vplivajo, motivirajo in navdihujejo druge. Samoobvladovanje zahteva uvid v lastne prednosti ter razvojne možnosti. Zahteva pa tudi voljo in disciplino pri lastnem razvoju.

- Strateško razmišljanje in zmožnost strateškega pogleda: premik paradigem v zdravstvu zahteva nove pristope in poglede $\mathrm{v}$ reševanju problemov. Vodje morajo biti sposobni iti preko tradicionalnih meja, da lahko raziščejo nove možnosti in perspektive. Strategi so orientirani v prihodnost, radovedni, delujejo na dolgi rok, upajo si tvegati, znajo postavljati prioritete, so bistri in kreativni.

- Mojstrsko izvajanje: vključuje uporabo ustreznih metod moči (formalnih in neformalnih) za motiviranje kolegov in ostalih deležnikov, da opravijo naloge in dosegajo zastavljene cilje. Vključuje tudi znanje, kako kreirati fokus okrog ključnih prioritet (prave naloge), in izgradnjo zmožnosti (pravi ljudje) za dosego vrhunskih rezultatov. Dobra strategija je brez pomena, če je nihče ne zna udejanjiti. Dobra izvedba pa zahteva tudi ocenitev, kaj deluje in kaj ne, ter zmožnost delujoče principe spraviti v prihodnjo prakso.

V slovenskem prostoru smo zasledili raziskavo Cimermana idr. (2003, 30), v kateri so identificirali ključne karakteristike slovenskih managerjev tretjega tisočletja in jih razvrstili v štiri skupine: (I) strateške karakteristike: vizionar, ciljno usmerjen, strateg in odločevalec; (2) organizacijske karakteristike: organizator, kadrovalec in delegator; (3) operativne vodstve- 
ne karakteristike: komunikator, motivator, pogajalec in timski vodja, ter (4) osebnostne karakteristike: etičnost, karizmatičnost ter odprtih nazorov. Petnajsta karakteristika, ki predstavlja sinergijo vseh prejšnjih, pa je obvladovalec sprememb.

\section{Vedenjski modeli}

Teorije osebnih značilnosti niso ponudile uspešnega in učinkovitega' vodenja, zato so se kasneje začele v okviru vedenjskega pristopa (Yukl 1998, 9) pojavljati t. i. vedenjske teorije in vedenjski modeli, ki preučujejo vedenje vodij, njihove odnose s podrejenimi in interakcije z njimi. $\mathrm{V}$ okviru teh teorij so nastajali različni stili vodenja. Pomemben vpliv na razvoj vedenjskih teorij sta imeli McGregorjevi teoriji X in Y (1960 in 1966, v Hersey in Blanchard 1993, 59-62). Teorija X gradi na domnevah, da so zaposleni praviloma leni in se delu izogibajo, nadrejeni jih morajo siliti in priganjati, zato je edini pravi stil vodenja avtoritativni, pri katerem je vodja trd, zahteven in neizprosen; ves čas zaposlene tudi nadzira. Teorija Y pa gradi na predpostavkah, da so ljudje pridni, se sami usmerjajo $\mathrm{k}$ delu in zanj prevzemajo odgovornost. Ustrezen način vodenja je participativni, kjer je vodja zaposlenim svetovalec in jih spodbuja, da sodelujejo pri načrtovanju in odločanju. Najvidnejše študije v okviru vedenjskih teorij so: študija Ohio State, michiganska študija ter Blakeov in Moutonov model mrežnega vodenja.

Raziskovalci Ohio State in michiganske študije so iz opisov vedenja vodij, ki so jih zapisali podrejeni, izluščili dve bistveni vedenji oz. orientiranosti vodij (Northouse 2001, 35):

- usmerjenost k nalogam oz. rezultatom,

- usmerjenost k odnosom oz. sodelavcem.

K nalogam usmerjen vodja načrtuje delo, postavlja delovne standarde, priskrbi potrebno opremo ter koordinira vse aktivnosti. K odnosom usmerjen vodja zaposlenim nudi pomoč, je dostopen, ustvarja ugodno delovno ozračje ter skrbi za razvoj zaposlenih. Dihotomija konceptov obeh študij kaže na dva nasprotujoča si načina vodenja, kar pomeni, da vodja, ki je usmerjen k zaposlenim, ne skrbi za rezultate, in obratno, vodja, usmerjen v rezultate (naloge oz. proizvodnjo), ne skrbi za delavce. Bistvo prizadevanj raziskovalcev v tistem času (od leta 1950 dalje) je bilo, kako kombinirati obe usmerjenosti vodij. 
Blake in Mouton (1985, v Bass 1990, 484-85) sta leta 1960 razvila model mrežnega vodenja, ki na podlagi obeh usmerjenosti managerjev omogoča presojo stila vodenja. Model je prikazan na sliki 9. Horizontalna os prikazuje skrb za proizvodnjo (naloge, rezultate), vertikalna os pa skrb za ljudi. Obe lestvici sta 9-stopenjski, kar pomeni, da model lahko meri 8I stilov. Nizka usmerjenost v proizvodnjo in nizka usmerjenost v ljudi pomeni nemoč vodje, njegovo izogibanje odgovornosti in neaktivnost. Stil r.9 pomeni visoko skrb za ljudi, kar povzroča prijetno vzdušje, ni pa rezultatov. Stil 9.I pa pomeni visoko skrb za naloge in ne za ljudi. Najboljši stil je timsko delo, ki vodi k odličnim rezultatom in zadovoljstvu zaposlenih.

\begin{tabular}{|c|c|c|c|c|c|c|c|c|c|}
\hline Visoka & 9 & \multirow{2}{*}{\multicolumn{2}{|c|}{$\begin{array}{l}\text { Stil } 1.9 \\
\text { vzdušje }\end{array}$}} & & & & \multirow{2}{*}{\multicolumn{3}{|c|}{$\begin{array}{c}\text { Stil } 9.9 \\
\text { timsko delo }\end{array}$}} \\
\hline \multirow{6}{*}{ 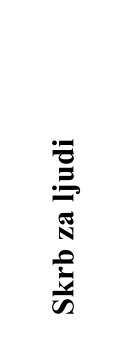 } & 8 & & & & & & & & \\
\hline & 7 & & & & & & & & \\
\hline & 6 & & & \multirow{3}{*}{\multicolumn{3}{|c|}{$\begin{array}{c}\text { Stil } 5.5 \\
\text { na sredini }\end{array}$}} & & & \\
\hline & 5 & & & & & & & & \\
\hline & 4 & & & & & & & & \\
\hline & 3 & & & & & & & & \\
\hline & 2 & \multirow{2}{*}{\multicolumn{2}{|c|}{$\begin{array}{l}\text { Stil } 1.1 \\
\text { nemoč }\end{array}$}} & & & & \multirow{2}{*}{\multicolumn{3}{|c|}{$\begin{array}{l}\text { Stil } 9.1 \\
\text { naloge }\end{array}$}} \\
\hline \multirow[t]{3}{*}{ Nizka } & 1 & & & & & & & & \\
\hline & & \begin{tabular}{l|l}
1 & 2 \\
\end{tabular} & 3 & 4 & 5 & 6 & 7 & 8 & 9 \\
\hline & & Nizka & Sk & $b$ za & pro & Izvoc & Injo & & oka \\
\hline
\end{tabular}

Slika 9: Model mrežnega vodenja

Vir: Blake in Mouton (1985, v Bass 1990, 484).

Stil vodenja r.9 lahko pripišemo skrbnežu, ki je pozoren na potrebe ljudi. Stil 9.9 pripada motivatorju, ki poskrbi, da so zaposleni pri delu zavzeti in imajo spoštljive odnose. Sredini pripada administrator, ki poskrbi za ustrezno delovno moralo ter razporedi nujna opravila. Stil I.I pripada pasivnemu politiku, ki se ne trudi za to, da je delo opravljeno, prav tako mu je vseeno za zaposlene. Stil 9. I pripada agresivnežu, ki mu je pomembno, da so naloge opravljene, čeprav so delovni pogoji nehumani. 


\section{Situacijski modeli}

Situacijske teorije gradijo na predpostavki, da vodja svoje vodenje prilagaja vsakokratni situaciji, ki jo sestaljajo narava (zahtevnost) naloge ter značilnosti podrejenih oz. skupine (izkušnje, strokovnost, prizadevnost, sposobnost). Pomembna začetna predstavnika tega pristopa sta Tannenbaum in Schmidt, ki sta razvila t. i. teorijo vedenjskega kontinuuma vodij (Hersey in Blanchard I993, I I7). Vodja lahko izbira med sedmimi stili vodenja, ki se raztezajo od avtoritativnega na eni strani do demokratičnega na drugi strani:

- avtoritativni stil vodenja, pri katerem vodja sam sprejema vse odločitve, in jih sporoči podrejenim ter posreduje usmeritve za delo;

- patriarhalni stil vodenja, pri katerem vodja prepričuje zaposlene o pravilnosti sprejete odločitve (»prodajanje «);

- posvetovalni stil vodenja, pri katerem vodja sprejema odločitve, dopušča pa vprašanja, odgovore in argumente zaposlenih;

- konzultativni stil vodenja, kjer nadrejeni obvešča podrejene o nameravanih odločitvah, podrejeni imajo tudi možnost izražati svoja mnenja in doseči njihovo upoštevanje;

- participativni stil vodenja, pri katerem skupina podrejenih oblikuje svoje predloge, nadrejeni pa se odloči za izbor predloga;

- delegativni stil vodenja, kjer skupina podrejenih sprejema odločitve v zvezi s problemi v okvirih, ki jih določi nadrejeni;

- demokratični stil vodenja, pri katerem skupina skupaj z nadrejenim sprejme odločitev, nadrejeni je povezovalec oz. moderator v skupini.

Fiedler je razvil kontingenčni model vodenja, po katerem se situacije ocenjujejo glede na tri faktorje oz. situacijske spremenljivke: odnos med vodjo in podrejenimi, strukturiranost (kompleksnost) naloge in moč vodjevega položaja (Northouse 200I, 76). Moč položaja v modelu pomeni možnost nagrajevanja in kaznovanja. Če ima vodja močno formalno pozicijo, lahko z njo v precejšnji meri vpliva na podrejene. Strukturiranost naloge se kaže v njeni težavnosti oz. zahtevnosti. Pri zahtevnih nalogah mora vodja dajati bistveno več navodil in pojasnil kot pri preprostejših nalogah. Odnos med vodjo in podrejenimi opredeljuje sprejetost vodje s strani podrejenih. Slika ı prikazuje Fiedlerjev kontingenčni model. 


\begin{tabular}{|c|c|c|c|c|c|c|c|c|}
\hline $\begin{array}{l}\text { Odnos med vodjo } \\
\text { in vodenimi }\end{array}$ & \multicolumn{4}{|c|}{ Dober } & \multicolumn{4}{|c|}{ Slab } \\
\hline $\begin{array}{c}\text { Strukturiranost } \\
\text { naloge }\end{array}$ & \multicolumn{2}{|c|}{$\begin{array}{c}\text { Visoko } \\
\text { strukturirana }\end{array}$} & \multicolumn{2}{|c|}{$\begin{array}{c}\text { Nizko } \\
\text { strukturirana }\end{array}$} & \multicolumn{2}{|c|}{$\begin{array}{c}\text { Visoko } \\
\text { strukturirana }\end{array}$} & \multicolumn{2}{|c|}{$\begin{array}{c}\text { Nizko } \\
\text { strukturirana }\end{array}$} \\
\hline \multirow[t]{2}{*}{ Moč položaja } & Velika & Majhna & Velika & Majhna & Velika & Majhna & Velika & Majhna \\
\hline & 1 & 2 & 3 & 4 & 5 & 6 & 7 & 8 \\
\hline Uspešen način & (usn & $\begin{array}{l}\text { Nizek LP } \\
\text { lerjenost }\end{array}$ & delu) & & $\begin{array}{r}\text { Visol } \\
\text { merjeno }\end{array}$ & $\begin{array}{l}\text { LPC } \\
\text { t k ljudem }\end{array}$ & & $\begin{array}{l}\text { Nizek } \\
\text { LPC }\end{array}$ \\
\hline
\end{tabular}

Slika ı : Fiedlerjev kontingenčni model

Vir: Fiedler 1967, v Northouse 2001, 77.

LPC (Least Preferred Co-worker) je merilo oz. ocena, ki jo vodja prejme od najmanj priljubljenega člana skupine. Visok LPC pomeni, da je vodja usmerjen $\mathrm{k}$ ljudem. Nizek LPC pa kaže na večjo usmerjenost k nalogam. Kritiki modela mu očitajo enodimenzionalnost stila vodenja, ki ima dve skrajnosti, usmerjenost $\mathrm{k}$ rezultatom ali sodelavcem, zanemarja pa lastnosti zaposlenih.

House-Mitchellov model poti in ciljev gradi na dognanjih študije Ohio State (Hersey in Blanchard 1993, I22). Model sestoji iz štirih stilov vodenja, ki jih vodja uporablja v odvisnosti od lastnosti zaposlenih in značilnosti oz. zahtevnosti dela:

- direktivni stil vodenja, pri katerem vodja daje natančna navodila in zaposlenim jasno pove, kaj pričakuje od njih, pojasni postopke ter določi rok za dokončanje nalog;

- participativni stil vodenja, pri katerem vodja v odločanje vključuje tudi zaposlene, upošteva predloge in mnenja ter se posvetuje z njimi, zaposlene pa vključuje tudi v postavljanje ciljev;

- podporni stil vodenja, pri katerem je vodja razumevajoč, podrejene spodbuja in jim pomaga, je dosegljiv in kreira atmosfero zaupanja, spoštovanja in enakopravnosti;

- izzivalni stil vodenja, pri katerem vodja postavlja visoke cilje in verjame, da jih bodo zaposleni tudi dosegli.

Hersey-Blanchardov situacijski model (Hersey in Blanchard 1993, 305-I5) prav tako vključuje štiri stile vodenja (avtoritarni oz. ukazovalni, 
mentorski oz. podporni, participativni, delegativni). Vodja izbere stil vodenja glede na stopnjo pripravljenosti oz. zrelosti sodelavca, ki se nanaša na njegovo usposobljenost za izvedbo naloge. Stopnjo zrelosti sta avtorja opredelila na štiristopenjski skali:

- RI je nizka stopnja zrelosti (nezmožni in nemotivirani za delo);

- $\quad R_{2}$ je nizka do zmerna stopnja zrelosti (nezmožni, toda motivirani);

- $\quad R_{3}$ je zmerna do visoka zrelost (zmožni, malo motivirani);

- $\quad R_{4}$ je visoka zrelost (zmožni in motivirani).

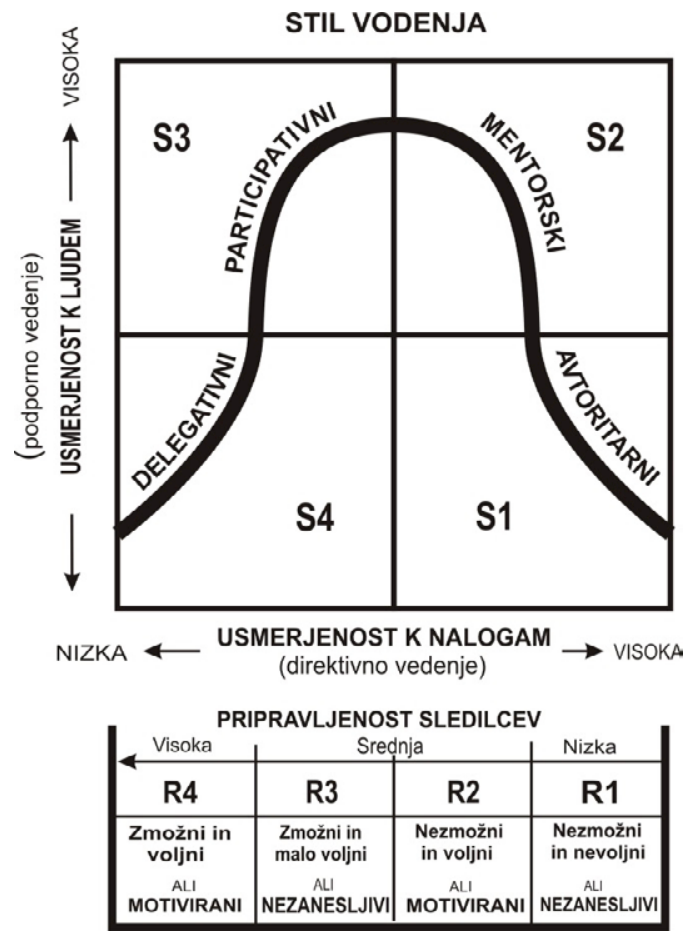

Slika ı : Model Herseya in Blancharda

Vir: Hersey in Blanchard 1993, 306.

Pri nizki stopnji zrelosti vodja uporabi avtoritarni stil vodenja, ki vključuje tudi kaznovanje, pri nizki do zmerni stopnji uporabi mentorski stil vodenja in po potrebi nagrajevanje, pri zmerni do visoki zrelosti uporabi participativni stil vodenja in zaposlenim ponudi zgled, pri visoki zrelosti pa uporabi delegativni stil vodenja in svojo strokovno avtoriteto. 
Slika I I prikazuje opisan model, $v$ katerem je razvidna medsebojna povezanost med stilom vodenja in stopnjo zrelosti.

Situacijske teorije ponujajo uporabo različnih stilov vodenja, ki naj jih vodja prilagaja glede na okoliščine. Uporaba naj bo premišljena, ne samo z vidika situacije, temveč tudi z vidika ciljev, ki jih želi doseči. Kot pravi Adizes (1996, 25), je npr. potrebno upoštevati tudi dejstvo, da je demokratični slog uspešen, ni pa učinkovit. Nasprotno pa je avtoritarni slog učinkovit, ni pa dolgoročno uspešen. Situacijske teorije so razširile razumevanje vodenja, ker so poleg stilov vodenja v svoje modele uvedle situacijske dejavnike, tj. značilnosti situacije, $v$ kateri vodenje poteka, ter lastnosti vodenih, ni pa jim uspelo natančneje opredeliti načinov vplivanja na zaposlene. Zato so raziskovalna dognanja o vodenju vodila do razlikovanja dveh načinov vodenja, transakcijskega in transformacijskega.

\section{Transformacijsko vodenje}

Burns $(1978,3-4)$ je prvi opredelil razlikovanje med transakcijskim in transformacijskim vodenjem, in sicer $\mathrm{v}$ sferi političnega voditeljstva. Burnsov koncept pa je Bass (1990, 53-54) razvil naprej in ga prilagodil za uporabo na poslovnem področju. Ko so bili zaposleni vseh nivojev in v različnih državah pozvani, da opišejo karakteristike in vedenja najučinkovitejših vodij, ki so jih imeli v preteklosti, so njihovi opisi obsegali veliko več kot »dajanje nagrade za dobre rezultate«. Opisovali so vodje kot navdihujoče, intelektualno stimulirajoče, izzivajoče, vizionarske, razvojno usmerjene in predane najboljšim načinom izvajanja dela. V mnogih primerih so jih opisali kot karizmatične (Walumbwa in Zhu 2004, 4). Literatura o vodenju je poudarjala motiviranje zaposlenih, kar sodi v vodenje $s$ pogojevanim nagrajevanjem oz. recipročni izmenjavi (značilno za transakcijsko vodenje), vse večje zahteve po spremembah v organizacijah ter spoprijemanje $\mathrm{z}$ odpori pa so vodili $\mathrm{k}$ poudarjanju demokratičnega, participativnega in k odnosom usmerjenega vodenja. $S$ tem načinom vodenja so imeli vodje veliko večji vpliv na prizadevanja zaposlenih za dobro opravljanje svojega dela.

Glavni konstrukti vodenja - transformacijsko, transakcijsko in vodenje laissez-faire - so oblikovali novo paradigmo razumevanja najmanjših in največjih učinkov stila vodenja. Ta se je uveljavila z namenom, da razširi dimenzije vodenja, ki so jih preučevali v prejšnjih raziskavah, in je gradila na primerjavah:

- avtokratsko proti demokratskoemu vodenju,

- direktivno proti participativnemu odločanju, 
- $\quad \mathrm{k}$ nalogam usmerjeno vodenje proti k odnosom usmerjenemu vodenju.

Bass je transformacijskega vodjo definiral kot osebo, ki ji zaposleni zaupajo, jo spoštujejo, so ji lojalni in so motivirani, da naredijo več, kot se od njih pričakuje (Yukl 1998, 325). Zaposlene ozavešča o posledicah njihovega ravnanja in vpliva nanje tako, da delujejo preko meja lastnih interesov, za višje cilje in v dobrobit organizacije ali skupine. Lussier in Achua (2007, v Hernandez 2010, 29) transformacijskim vodjem pripisujeta naslednje skupne karakteristike:

- vidijo se kot močni agenti sprememb;

- $\quad$ so vizionarski posamezniki, ki imajo visoko stopnjo zaupanja v svojo intuicijo;

- tvegajo, vendar ne brezglavo;

- artikulirajo pomembne vrednote, ki usmerjajo vedenje znotraj organizacije;

- imajo razvitih veliko veščin in preudarno premislijo, predno reagirajo;

- $\quad$ verjamejo v ljudi ter imajo občutek za njihove potrebe in skrbi;

- $\quad$ so fleksibilni in odprti za učenje iz izkušenj.

Bass (1990, 190) transformacijskemu načinu vodenja pripisuje $5 \mathrm{di-}$ menzij oz. faktorjev - opisujemo jih spodaj.

- Idealiziran vpliv (vedenje) se pri vodji kaže v tem, da postavlja interese drugih pred lastne interese. Pri svojem delu je dosleden. Deluje skladno z vrednotami in vizijo, za katere uspe prepričati tudi sodelavce. Svojo moč uporablja le takrat, ko je nujno potrebno (Walumbwa in Zhu 2004, 30).

- Karizma (idealiziran vpliv - pripisan) se kaže v lastnostih transformacijskih vodij, ki jim jih pripisujejo sodelavci. So zgled svojim sodelavcem, ki se želijo identificirati z njimi, saj svoje vodje občudujejo in menijo, da imajo izredne sposobnosti. Pri svojem delu jih vodijo visoki moralni in etični standardi. Sodelavci jih zelo spoštujejo in jim zaupajo. Karizmatični vodja oblikuje vizijo in sodelavcem pokaže, kaj je njihovo poslanstvo. Sodelavci so pripravljeni podpreti vizijo vodje in se dodatno potruditi (Northouse 200I, I37). Pri ljudeh vzbujajo entuziazem. Karizma je vodjem v veliko pomoč, čeprav jo mnogi avtorji vidijo kot odnos med vodjo in sodelavcem in ne kot lastnost vodje (Kakabadse in Kakabadse I999, 20I; Cimerman idr. 2003, 71- 
72; Mayer 2003, 372). Med karizmatičnim in transformacijskim vodjem po Northouseju (200ı, 134) obstaja tudi razlika. Karizmatični voditelj je rad v soju žarometov in si želi biti središče pozornosti, transformacijski vodja pa želi dosegati rezultate, zato pozornost usmerja na cilj. Karizmatični vodja ima veliko potrebo po moči in vero v svoje lastne vrednote ter prepričanja. Mittal $(2015,27)$ karizmo vidi kot enostranski proces vplivanja vodje na sledilce, da ti prevzamejo vizijo vodje, kar pa ne sledi konceptu transformacijskega vodenja, pri katerem gre za vzajemen vpliv vodje in sledilcev, ki pri obojih povzroča »transformacijo《.

- Intelektualna stimulacija se kaže skozi spodbujanje h kreativnosti in $\mathrm{k}$ inovativnosti ter postavljanje privlačnih izzivov oz. ciljev. Vodja sodelavce podpira pri novih idejah in načinih dela, spodbuja učenje in timsko delo. Skrbi tudi za lasten razvoj.

- Individualna obravnava se kaže skozi priznavanje individualnih razlik in potreb sodelavcev. Eni potrebujejo več spodbude, drugi več podpore ali navodil, spet tretji več avtonomije. Vodja je trener in mentor, ki podrejenim omogoča rast. Skozi delegiranje nalog razvija ljudi. Je zagovornik vsakega zaposlenega. Poskrbi, da ima vsak sodelavec potrebno podporo in potrebno opremo za opravljanje svojih nalog.

- Navdihujoča motivacija se kaže skozi motiviranje podrejenih z ustvarjanjem timskega duha, navdušenja in optimizma. Komunikacija med vodjo in sodelavcem je neposredna. Sodelavci se počutijo cenjene in zaradi tega so samozavestnejši. Počutijo se tudi varne, saj vedo, da jim bo ob nastalih ovirah vodja stal ob strani.

V literaturi zasledimo, da je transformacijsko vodenje, ki zajema vse svoje prepoznane dimenzije, povezano $\mathrm{z}$ učinkovitostjo in s pozitivnimi rezultati v organizacijah (Jelovac in Maške 2012, 76; Tomlinson 2012, 34; Xirasagar, Samuels in Stoskopf 2005, 730; Zaersabet, Ahangaran in Chegini 2013, 89; Mokhber, Wan Ismail in Vakilbashi 2015, 233) ter pozitivno vpliva na organizacijsko kreativnost in inovativnost. Medčloveški odnosi in ustvarjanje pogojev za čimvečji prispevek zaposlenih v današnjih organizacijah postajajo odločilnega pomena, kar pogojuje tudi nova spoznanja v okviru teorij s področja managementa človeških virov. Svetlik in Zupan $(2009,47)$ pravita, da morajo transformacijskemu stilu vodenja organizacije prilagoditi tudi zaposlitvene odnose, ki ne morejo temeljiti zgolj na menjavi med delodajalcem in delojemalcem, temveč morajo 
razvijati relacijske zaposlitvene odnose, ki temeljijo na dolgoročni povezanosti med organizacijo in zaposlenimi.

\section{Transakcijsko vodenje}

Transakcijski vodja dobro pozna naloge, ki jih morajo zaposleni opraviti, da dosežejo pričakovane rezultate. Zelo dobro pozna tudi vloge zaposlenih. Dober je v prepoznavanju potreb in želja in v skladu z njimi tudi obljublja nagrade, če bodo zaposleni dosegali želene učinke (Walumbwa in Zhu 2004, 22). Podrejenim jasno sporoča, katero delo in kako mora biti opravljeno. Pri njih podpira izrazit individualen interes in daje priznanja za dosežke. Transakcijsko vodenje označujejo trije faktorji (Northouse 200 I, I 40), ki jih opisujemo spodaj.

- Pogojevano nagrajevanje, ki se kaže v transakcijah oz. izmenjavah (pogojnih nagradah) s sodelavci, če izpolnijo vnaprej dogovorjene obveznosti. Vodja z nagrado, ki je lahko materialna ali psihološka, prepriča sodelavce, da opravijo svoje naloge. Osredotoča se na zunanje dejavnike motivacije. Notranja motivacija pri zaposlenih mu ni mar. $\mathrm{V}$ praksi svoje vodenje izvaja na način pogajanj, največkrat barantanja z zaposlenimi. Vodja na ta način kontrolira nagrade, sodelavci pa kontrolirajo raven svojih prizadevanj in $\mathrm{z}$ njo povezanih rezultatov. Vodja stimulira $\mathrm{z}$ denarjem, s posebnimi privilegiji, z napredovanji, s posebnimi izobraževanji, skratka, vzpostavi individualiziran sistem nagrajevanja.

- Management z izjemami (aktivno) je dimenzija, ki vključuje negativno povratno informacijo in korektivno kritiko. Vodja aktivno opazuje in nadzira delo sodelavcev, vključi pa se le v primeru odstopanj od standardov in dogovorjenih pravil ter v primeru spodrsljajev in napak. Negativno ravnanje izpostavi in vsem zaposlenim sporoči, kaj se ne sme več zgoditi. Ko vse teče normalno, se vodja ne odziva.

- Management z izjemami - (pasivno) je dimenzija, pri kateri vodja svojih podrejenih ne opozarja na nepravilnosti ali nedoseganje rezultatov. Pusti, da delajo po svoje. Ocenjuje jih na koncu. Zaposleni šele ob končni slabi oceni dobijo povratno informacijo o slabem delu. Vodja čaka, dokler se ne pojavijo večji problemi, šele potem začne ukrepati.

Transakcijsko vodenje je osredotočeno na praktični vidik vodenja. Temelji na hierarhiji, pri kateri vodja uporablja svojo formalno moč v obliki nagrad in kazni. Poudarja doseganje ciljev znotraj obstoječih pravil 
ter kulturnih norm organizacije. Ne spodbuja inovativnosti. Učinkovit je v stabilnih razmerah (Možina idr. 2002, 532) in skrbi predvsem za to, da delo poteka brez večjih zastojev. Transformacijsko vodenje pa izboljšuje rezultate dela ob istočasnem razvijanju vseh zaposlenih. V nemirnih časih uvajanja sprememb je ta stil vodenja primernejši od transakcijskega.

\section{Vodenje laissez-faire}

Izraz laissez-faire prihaja iz francoščine in pomeni »roke proč - naj gredo stvari svojo pot«. Po naše bi tovrstno vodenje lahko poimenovali kar nevodenje oz. vodenje »brez vajeti«. Vodja se izogiba se vsakršni odgovornosti, odločitve prepušča drugim. Zaposlenim ne nudi nobene podpore. Ne organizira nobenih sestankov, med njim in podrejenimi praktično ni socialnih interakcij. Stil vodenja »brez vajeti« je popolnoma neučinkovit, občasno je primeren le za vodenje visoko usposobljenih ekspertnih timov znotraj učečih se organizacij. Za tovrstne time so značilni samousmerjajoče se delovanje, izjemna predanost delu in ekspertnost, ki jim omogoča samostojno delovanje.

\section{Vodenje in čustvena inteligenca}

Veliko avtorjev (Weisinger 2001, 19; Goleman, Boyatzis in McKee 2002, 74) ugotavlja, da je pri vodenju čustvena inteligenca izjemnega pomena. Opredelimo jo kot sposobnost zaznavanja, razumevanja in izražanja lastnih čustev ter zaznavanja in razumevanja čustev drugih. Od čustvene inteligence vodje je odvisno, kako uspešen bo v odnosih s sodelavci. Lahko bo ustvarjal prijetno in sodelovalno delovno vzdušje ali pa bo tudi sam pripomogel k negativnemu in strupenemu ozračju. Goleman, Boyatzis in McKee $(2002,49)$ prvemu načinu vodenja pravijo resonančno vodenje, drugemu načinu pa disonančno vodenje. Med resonančne sloge vodenja uvrščajo štiri (Goleman, Boyatzis in McKee 2002), ki jih opisujemo spodaj.

- Vizionarsko vodenje - vodja postavi cilj in ne začrta poti. Ljudem pušča svobodo, da uvajajo novosti. Predstavi jasno sliko prihodnosti in vlogo posameznika v celotnem dogajanju. Zaposleni razumejo, kaj se od njih pričakuje. Vizionarski vodja je karizmatičen in ljudje radi delajo zanj. Uspe mu ohraniti najdragocenejše zaposlene. Ker so zaposleni v sozvočju z vrednotami, s cilji in z vizijo organizacije, postane ta organizacija njihov najljubši delodajalec. Vizionarski slog je primeren, ko se pojavi potreba po pre- 
oblikovanju organizacije ali ko organizacija potrebuje jasen občutek za smer.

- Mentorsko vodenje - mentor pomaga zaposlenim, da prepoznajo svoje prednosti in šibke točke. Spodbuja jih, da si postavijo dolgoročne razvojne cilje in jim pomaga pripraviti načrt zanje. Zaposlene motivira in iz njih izvabi tisto, kar je najboljše. Pred njih postavlja zanimive izzive, ki omogočajo njihov razvoj. Usmerja jih s povratnimi informacijami. Mentorski slog ne dopušča pretiranega nadzora nad zaposlenimi, ker lahko spodkopava samozavest zaposlenih in povzroča manjšo storilnost. Mentor deluje kot svetovalec, raziskuje cilje in vrednote zaposlenih ter jim pomaga razvijati njihove sposobnosti. Mentorstvo se najbolje obnese z zaposlenimi, ki kažejo iniciativo in so motivirani za svoj strokovni razvoj. Primeren je takrat, ko je zaposlenemu treba pomagati, da izboljša svojo storilnost $\mathrm{z}$ razvijanjem sposobnosti. $\mathrm{Ne}$ obnese pa se, kadar zaposlenim manjka motivacije.

- Tovariško vodenje - tovariški vodja ceni ljudi in spoštuje njihova čustva. Manj poudarja doseganje ciljev in se raje posveča čustvenim potrebam zaposlenih. Prizadeva si, da bi bili zaposleni srečni, ustvarja ubranost in krepi timski duh. Tovariški slog bolj malo vpliva na storilnost, ima pa velik pozitiven učinek na ozračje v skupini in je glede uspešnosti takoj za vizionarskim in mentorskim slogom. Voditelj, ki se zaveda, da zaposleni v težkih časih potrebujejo čustveno oporo, lahko neverjetno okrepi lojalnost in povezanost. Tovariški vodja ustvarja ubranost in prijateljsko sporazumevanje. Tovariški slog močno krepi moralo in izboljšuje razpoloženje zaposlenih. Primeren je, kadar želimo v timu doseči ubranost, okrepiti moralo, izboljšati komuniciranje ali povrniti spodkopano zaupanje v organizacijo.

- Demokratično vodenje - gradi na timskem delu in sodelovanju. Demokratičen vodja je odličen poslušalec, je mojster sodelovanja in se vede kot član tima in ne kot šef. Zna pomiriti spore in ustvariti ubranost v skupini. Demokratičen slog je zelo koristen, ker iz ljudi izvabi sveže zamisli. Ljudje sodelujejo pri odločitvah, kar jih seveda bolj motivira za delo. Da bodo zaposleni pripravljeni izražati svoje poglede, ideje in zamisli, mora vodja ustvariti varno ozračje, v katerem ne bodo »letele glave «. Demokratični slog uporabljamo, ko je treba pridobiti soglasje ali zaposlene pripraviti $k$ dejavnejšemu sodelovanju. Ta slog ima tudi svoje po- 
manjkljivosti: zaradi želje po soglasnem sprejetju se lahko sprejemanje odločitev vleče v nedogled.

Naslednja dva stila vodenja sta disonančna, vodja ju mora uporabljati zelo previdno.

- Diktiranje tempa - uporabljajo ga vodje, ki pričakujejo odličnost, pri tem pa so sami zgled. Zelo dobro se obnese v tehničnih panogah, med visoko usposobljenimi strokovnjaki, ali če imamo zelo motivirano prodajno osebje. Diktiranje tempa prinese rezultate, če so člani skupine zelo sposobni, motivirani in potrebujejo malo pomoči. $Z$ nadarjenimi ljudmi lahko vodja $\mathrm{z}$ uporabo tega sloga delo opravi pravočasno (npr. ko so kratki roki). Ta slog je treba uporabljati previdno, ker lahko zaposleni dobijo občutek, da so pod prehudim pritiskom. Tovrstni vodje tudi ne znajo usmerjati in pričakujejo, da bodo ljudje sami vedeli, kaj morajo storiti. Takšen vodja je popolnoma osredotočen na rezultate in svoje cilje in mu ni mar za ljudi. Rezultat je jasen: zastrupljeno ozračje, slabo vzdušje. Tudi rezultat je mnogokrat ravno nasproten od pričakovanega: bolj ko vodja pritiska na ljudi, več zaskrbljenosti povzroča. Zmeren pritisk ljudem da potreben zagon, da delo končajo v roku, prehudi in nenehni pritiski pa delavce hromijo. Pritisk ohromi njihovo inventivnost. Ljudje sicer takšnega vodjo ubogajo, kar kratkoročno sicer prinese rezultate, dolgoročno pa ne pomeni uspeha.

- Ukazovalni slog - je nasilen in poteka na način »storite to, ker sem jaz tako rekel«. Takšen vodja zahteva takojšnjo izpolnitev ukazov, ne zdi se mu vredno razložiti razlogov zanje. Zateka se $h$ grožnjam in vse nadzira. Od vseh slogov je ukazovalni najmanj učinkovit. Ukazovalen in hladen vodja pokvari čustveno ozračje $\mathrm{v}$ podjetju in razpoloženje postane mučno. Ukazovalen vodja zaposlene redko pohvali in jih pogosto kritizira. $S$ tem spodkopava njihovo samozavest in zadovoljstvo pri delu. Ukazovalni slog pa je lahko pomemben del vodstvenega repertoarja čustveno inteligentnega vodje, ki ga zna uporabljati. Ta slog je lahko učinkovit, ko je organizacija v krizi.

Sodobnejše teorije o vodstvenih kompetencah čustvenointeligenčne kompetence uvrščajo med najpomembnejše. Dulewicz in Higgs (2005, II I) sta razvila integriran model petnajstih managerskih kompetenc, ki so pomembne $\mathrm{z}$ vidika vodenja. Med njimi je kar sedem čustvenointe- 
ligenčnih kompetenc (Müller in Turner 2007, 23), druge spadajo med splošnointelektualne in managerske kompetence.

Čustvena inteligenca je temelj dobrega vodenja, kar Goodwin (2006, IO2) zelo nazorno prikazuje z opisom nekompetentnega managerja. Tako kot nekompetentni zdravnik tudi nekompetentni manager povzroči slabo organizacijsko življenje in naredi ljudi bolne ter manj vitalne. Zaradi tega je čustvena inteligenca pomembna; predvsem je pomembno, kako vodja obvlada sebe in odnose z drugimi. Vodja, ki dobro pozna sebe, ima manj konfliktov z osebjem.

\section{Avtentično vodenje}

Sodobne organizacije poudarjajo izobraževanje in učenje vseh svojih zaposlenih, saj je znanje ključna konkurenčna prednost $\mathrm{v}$ današnjem neizprosnem tekmovanju. Znanje ${ }^{2}$ je bogatejše od informacij. $Z$ učenjem in pridobljenim znanjem so organizacije pripravljene na stalno prilagajanje spremembam. Avtor koncepta učeče se organizacije Senge (1990, 5-13) navaja pet prvin za izgradnjo takšne organizacije: sistemsko razmišljanje, osebno odličnost, mentalne modele (okvir za naše kognitivne procese), skupno vizijo in timsko učenje. Ferjan (1999, I25) izpostavlja sodelovalno kulturo v organizaciji kot pogoj za uveljavljanje koncepta učeče se organizacije. $V$ sodelovalni kulturi so vsi posamezniki enako cenjeni in imajo občutek medsebojne povezanosti. Pomemben način učenja osebja je učenje drug od drugega. Učenje je treba uvesti ob vsaki priložnosti, pred delom, med delom in po delu (Collison in Parcell 2002, 40). Bulc (2006, 43) meni, da je treba v učečih okoljih znanje povezovati in ga čim učinkoviteje izkoristiti za vzdrževanje produktivnosti, kakovosti in ustvarjanje novih priložnosti. Odločilnega pomena so ciljno usmerjeni izobraževalni programi, ki sistematično nadgrajujejo potrebna znanja. Mentorstvo pa je oblika notranjega prenosa znanja in izkušenj na širši krog sodelavcev. Znanje vse bolj postaja vrednota. Tudi LeBrasseur, Whissell in Oyha (2002, I43) ugotavljajo, da stalno organizacijsko učenje izboljša delovanje bolnišnice.

$\mathrm{V}$ zadnjem času se je pojavil nov model vodenja, t. i. avtentično vodenje, ki omogoča vpeljavo koncepta učeče se organizacije (Dimovski, Penger in Peterlin 2009, 23). Gre za relativno novo teorijo s področja vodenja, ki gradi na pozitivnem managementu in pozitivnem organizacijskem vedenju ter etiki. Dimovski, Penger in Peterlin (prav tam) pravijo, da avten-

$2 S S K J(2000)$ znanje opredeljuje kot celoto podatkov, ki si jih kdo vtisne v zavest z učenjem, študijem. 
tično vodenje pomeni vodenje $\mathrm{v}$ skladu $\mathrm{z}$ lastno osebnostjo in prepričanji ob istočasnem širjenju pozitivnih vrednot med zaposlene ter spodbujanju zaposlenih k njihovi osebni in strokovni rasti. Avtentični vodje vodijo z zgledom. S svojimi pozitivnimi čustvi ustvarjajo ugodno delovno klimo. Zagotavljajo odprt dostop do informacij in vsem zaposlenim nudijo enake priložnosti za učenje in razvoj (prav tam, I09). Avtentično vodenje je vodenje iz srca in prihaja iz vodjevega notranjega bistva, prežetega s pozitivnim vrednostnim sistemom ter zaupanjem $\mathrm{v}$ poslanstvo organizacije (Fraser 20I 4, 84). Etičnega vedenja se ne da zagotoviti zgolj z retoriko o etiki ali z napisanimi pravili o etičnem vedenju, temveč $s$ kreiranjem organizacijske kulture, $\mathrm{v}$ kateri so etični ideali vključeni v osrednje vrednote organizacije.

$\mathrm{Na}$ prvi pogled je avtentično vodenje podobno transformacijskemu, vendar se oba pristopa v določenih vidikih razlikujeta (Avolio in Gardner 2005, 329). Ključno razlikovanje je $\mathrm{v}$ tem, da se avtentični vodja globoko zaveda samega sebe, svojih vrednot in prepričanj. Predstavljajo mu osnovo, $s$ katero vpliva na sodelavce. To počne $\mathrm{z}$ dejanji in ne samo $\mathrm{z}$ besedami. Tudi transformacijski vodja deli vizijo organizacije s svojimi sodelavci, vendar gre avtentični vodja globlje. Živi in širi svoje vrednote med sodelavce, ustvarja pozitivni psihološki kapital, ki vključuje elemente pozitivnega organizacijskega vedenja, kot so samozavest, optimizem, upanje in prožnost.

V okolju hitrih sprememb se lastnosti, znanje, veščine in vedenje vodij stalno spreminjajo. Kompetenčni modeli se prilagajajo zahtevnim okoliščinam, $\mathrm{v}$ katerih vodenje poteka. $\mathrm{V}$ vsakem izmed nas pa je del osebnosti, za katerega lahko trdimo, da je avtonomen, se ne spreminja in je skozi ta očala tudi instinktiven, pristen. Ko delujemo v skladu s tem delom svoje osebnosti, smo najbolj sproščeni in najučinkovitejši. $V$ tem se kaže avtentičnost vodje, ki jo sodelavci zaznavajo. Zaradi nje izkazujejo večje zadovoljstvo in veselje do dela ter pripadnost organizaciji. 



\section{Značilnosti nekaterih modelov managementa sprememb}

Pri organizacijskih spremembah je treba ločevati med vsebino in procesom spreminjanja. Vsebina je odgovor na $\gg \mathrm{kaj} \ll$ spreminjamo, proces $\mathrm{pa}$ odgovarja na vprašanje, »kako《 spreminjamo. Vsebina se veže na vizijo oz. namen spremembe ter strategijo, proces pa na implementacijo in prilagajanje oz. na to, kako je sprememba načrtovana, predstavljena, implementirana in potem vzdrževana (Burke 2002, I4). Učinki inkrementalnih sprememb v organizacijah se kažejo v organizacijskem razvoju, učinki radikalnih sprememb pa v njihovem preoblikovanju oz. transformaciji. Obvladovanje procesov spreminjanja je povezano z reševanjem problemov, pri čemer je management mišljen kot osrednji dejavnik za njihovo reševanje. Kovač, Mühlbacher in Kodyek (20I2, 33) opredeljujejo management sprememb kot praktični managerski koncept, ki služi kot pripomoček za delovanje managerjev, da uspešno in učinkovito dosegajo izvedbo potrebnih sprememb. Management mora biti pozoren na potencialne sprožilce sprememb, da se organizacija lahko proaktivno odzove nanje.

Brown $(2012,5)$ pravi, da sprememba vključuje tri vidike: ljudi, procese in kulturo. V preteklosti je bil poudarek na procesih, avtor pa ugotavlja, da je $\mathrm{v}$ sodobnih organizacijskih sistemih treba uravnotežiti vse tri vidike. Prav zato je uspešno spremembo težko zapovedati, biti mora spodbujena z motivacijo. K njej se pristopa timsko. Avtor (Brown 20I 2, 2 I-25) opisuje timske vloge v managementu sprememb. Sponzor je človek, ki ni vključen $\mathrm{v}$ vsakodnevne aktivnosti, povezane $\mathrm{s}$ spremembo, vendar spremembo podpira in nadzira napredek. Zagotovi potrebne vire in sprejme končno odgovornost za njen uspeh ali neuspeh. Manager sprememb je oseba, ki vodi spremembo, in je vzor za nove oblike vedenja oz. za novo 
realnost. Lahko je izkušen projektni manager v organizaciji. Odgovoren je za vsakodnevne aktivnosti, ki so vezane na implementacijo spremembe. Agenti sprememb so ključnega pomena v procesu spreminjanja. So pripravljeni eksperimentirati in dobro razumejo razvojne procese v organizaciji. Ta vloga je pogosto dodeljena srednjemu managementu. Prav tu je potrebna pozornost, da ni podvržen pritiskom $z$ vrha in podrejenih. Agenti sprememb so odgovorni za lajšanje uvajanja spremembe. To dosegajo na različne načine: $s$ pridobivanjem predanosti za spremembo, $\mathrm{z}$ nadziranjem in $s$ poročanjem o napredku, z odkrivanjem in zmanjševanjem odporov in s širjenjem uspehov, povezanih s spremembo. Dobro poznajo nujnost spremembe, kaj je možno doseči in česa ne, ter razumejo celoten proces spreminjanja. Imajo razvite vodstvene in medosebne veščine. Vešči so tudi v promoviranju spremembe. Znajo zgraditi podporne strukture. Zadnja timska vloga je šampion spremembe (angl. change champion). To so zgodnji zagovorniki spremembe, ki verjamejo, da bo sprememba organizaciji prinesla koristi in da bo njena implementacija uspela. Nimajo nobenih odgovornosti, vezanih na spremembo. So naravni promotorji organizacijske spremembe. O spremembi govorijo pozitivno in na neformalni način podpirajo kolege. Ker so to običajno veliki strokovnjaki, jim sodelavci tudi močno zaupajo (Branagan 20ro, 9).

Teorija ponuja mnogo modelov' managementa sprememb, ki na nazoren način pokažejo, kako pristopati $\mathrm{k}$ različnim spremembam. $\mathrm{V}$ nadaljevanju bomo predstavili nekaj pomembnejših.

\section{Lewinov osnovni model}

Eno najstarejših teorij o managementu sprememb je postavil Kurt Lewin. Proces spreminjanja je razdelil v tri faze (Yukl 1998, 440):

- Unfreezing (odmrznitev stanja) - to je faza, pri kateri ljudje spoznajo, da stari načini dela niso več primerni. Spoznanje je lahko posledica krize ali prepričevanj managementa o nevarnih posledicah trenutnega funkcioniranja organizacije. Cilj te faze je zmanjšati sile, ki podpirajo trenutno stanje. Oblikovati je potrebno vizijo in pridobiti čim več podpornikov ali vsaj omejiti nasprotnike. Kadar je nasprotovanje preveliko, je treba izvajati oba pristopa: povečati podporo za spremembo in na drugi strani zmanjšati odpore. Potrebni scenariji so informiranje, sodelovanje in snovanje pristopov $\mathrm{k}$ spremembi. Namen prve faze

I Biloslavo (1999, 6) model opredeljuje kot obliko poenostavitve stvarnosti, ki zajema le izbrane značilnosti. 
je motivirati in pripraviti ljudi za spremembo. Pri drastični odmrznitvi stanja Hersey in Blanchard $(1993,382)$ predlagata štiri pristope: (I) fizično odstranitev posameznikov z močno usidranimi viri informacij, rutino in s socialnimi povezavami; (2) slabljenje vseh destruktivnih vedenj; (3) zmanjševanje pomena izkušenj posameznikov, da ozavestijo stara vedenja kot neprimerna, in (4) uporabo nagrajevanja za pripravljenost za spremembo in kaznovanja za nepripravljenost.

- Changing (udejanjanje spremembe) - v tej fazi se spremenijo procesi in strukture ter vedenja zaposlenih, ki omogočajo uvajanje novosti. Ko posamezniki postanejo motivirani za spremembo, so pripravljeni sprejeti nove vzorce vedenja. Ta proces se odvija skozi dva mehanizma: identifikacijo in integracijo. Identifikacija se zgodi, ko se pojavi nov način vedenja, ki je prepoznan kot ustrezen, in se posamezniki iz njega lahko učijo. Integracija pa se pojavi, ko se posamezniki znajdejo v situaciji, ki od njih zahteva novo vedenje, če želijo biti uspešni. Novih vedenjskih vzorcev se ne učijo le zaradi potrebe po preživetju, ampak zaradi tega, da bodo kos novim situacijam, ki jih sproža sprememba (Hersey in Blanchard I993, 382). Učinkovita sprememba je vedno posledica uporabe obeh mehanizmov. Včasih se zgodi, da se pri posamezniku, ki je z nagradami ali kaznimi »potisnjen« $\mathrm{v}$ spremembo, želeno vedenje ohranja le do takrat, ko je vodja oz. agent spremembe prisoten. $V$ trenutku, ko ta nadzor popusti, tudi omenjeni posameznik zapade v stare tirnice delovanja oz. vedenja.

- Refreezing (ponovna zamrznitev) - predstavlja fazo, pri kateri se novo vedenje utrdi oz. se pridobljena vedenja integrirajo v vzorce vedenja posameznikov. Če je novo vedenje internalizirano že med fazo učenja, se faza ponovne zamrznitve pospeši, ker se je izvedla avtomatično, na naraven način. Če se je posameznik novega vedenja naučil skozi identifikacijo, pa bo to vedenje ohranjal le v obdobju trajanja vpliva in nadzora. Procesi, strukture in ostali mehanizmi morajo podpirati nov način delovanja organizacije in novo vedenje in pri tem je treba vztrajati.

Več kot 60 let so raziskovalci prispevali predloge oz. modele, ki bi organizacijam pomagali sistematično napredovati skozi večfazne procese implementiranja sprememb (Holt idr. 2003, 262). Začetno Lewinovo konceptualizacijo so kasnejši avtorji razširili na več faz. $V$ nadaljevanju predstavljamo enega med prepoznavnejšimi faznimi modeli - Kotterjev model. 


\section{Kotterjev procesni model}

Enega izmed bolj poznanih in uveljavljenih procesnih modelov je razvil Kotter (1998a, 17), ki ugotavlja, da je radikalno spremembo možno doseči le z izjemnim trudom. Postavil je okvir osmih korakov, s katerimi je opisal proces spreminjanja oz. transformiranja organizacije.

- Ustvariti občutek nujnosti za spremembo - če ljudje ne čutijo potrebe po spremembi, potem je ne bodo sprejeli ali sodelovali v procesu spreminjanja. Vršni management je s tega vidika v boljšem položaju, ker intenzivneje sodeluje z zunanjim okoljem, zato vidi potrebo po spremembi prej kot ostali zaposleni. Ta začetni korak je odločilnega pomena, saj z njim management ustvari nujno potrebno pripravljenost za sodelovanje. Občutek nujnosti se lahko ustvari s prepoznano krizo, novimi priložnostmi, postavitvijo previsokih ciljev ipd.

- Sestaviti vodilno koalicijo - prepričevanje ljudi za podporo radikalni spremembi ni lahko delo, še težje je za posameznika, zato je pomembno zgraditi močno in kompetentno koalicijo strokovnjakov, ki bo usmerjala vsa prizadevanja v zvezi s spremembo. To morajo biti posamezniki z močno avtoriteto, $s$ kredibilnostjo in z izjemnim strokovnim znanjem, ki bodo s svojim vplivom lažje uvajali spremembo. V nadaljevanju je treba zgraditi zaupanje v spremembo, kar vodilna koalicija lahko počne s pogovori, številnimi skupnimi aktivnostmi in sestanki. V tej fazi je pomembna tudi postavitev skupnega cilja.

- Razvoj vizije in strategije - namen vizije je, da jasno predstavi sliko prihodnosti, ki bo pomagala usmerjati prizadevanja za spremembe, motivirati in usklajevati delovanje večjega števila zaposlenih. Glede usmeritve si morajo biti zaposleni enotni. Vizija mora biti razumljiva, temeljiti mora na razumevanju organizacije. Vizija in strategija zaposlenim pokažeta pravo pot in smisel spremembe. V razvoj vizije morajo biti vključeni ključni ljudje. Njena priprava ni lahka, saj poleg poznavanja organizacije zahteva precejšnjo mero ustvarjalnosti.

- Sporočanje vizije in strategije zaposlenim - ljudje morajo dojeti smisel in namen spremembe. Management uporablja zadostno in ustrezno komunikacijo, da vizijo predstavi vsem zaposlenim. Komunikacija mora biti preprosta in razumljiva. Ni priporočljivo uporabljati strokovnih izrazov. Mora se ponavljati, da se ljudje identificirajo z nameni in cilji. Komunikacija mora biti dvosmer- 
na in ne samo v obliki enostranskega sporočanja. Management oz. nosilci odločanja morajo biti zgled.

- Opolnomočenje zaposlenih - kaže se v pooblaščanju zaposlenih za prevzemanje pomembnejših nalog ter opogumljanju za prevzemanja tveganja. Cilj je pooblastiti in motivirati ciljne osebe za odstranjevanje ovir na poti k spremembam. Zaradi odporov je pomembno, da se te ovire sproti odstranjujejo, sicer ljudje postanejo frustrirani. Še posebno je pomembno soočenje $\mathrm{z}$ nasprotniki spremembe.

- Načrtovanje in doseganje vmesnih kratkoročnih rezultatov - vmesni uspešni rezultati morajo biti vidni. Kratkoročni uspehi upravičujejo stroške in pomagajo okrepiti motivacijo in moralo. Pomembno je poudarjanje pozitivnih rezultatov in vztrajanje pri zagonu. Vmesni uspehi lahko prepričajo nekatere dvomljivce in nasprotnike spremembe. Ti dosežki so spodbuda k nadaljevanju in potrditev, da je organizacija na pravi poti.

- Utrjevanje že vpeljanih sprememb in kreiranje novih - kratkoročni uspehi, ki so omenjeni v prejšnjem koraku, so nujni, vendar lahko zaustavijo nadaljnja prizadevanja. Prevelika vnema ob doseženih vmesnih ciljih lahko ogrozi končen rezultat. Organizacija ne sme izgubiti občutka nujnosti. Delne uspehe mora management izrabiti za izgradnjo novih projektov sprememb. Treba je vključiti nove osebe in jih podpreti. Odločevalci morajo ohranjati transparentnost višjih ciljev.

- Institucionalizacija novih pristopov in načinov dela - novo stanje je treba spraviti v ustaljene prakse in ga vzdrževati. Novi načini obnašanja in vrednote se bodo odražali v kulturi takrat, ko se bodo izkazali za boljše od predhodnih. V tej fazi sta pomembna intenzivna komunikacija in poudarjanje novih vrednot. Za spremembo kulture pa je včasih potrebna zamenjava oseb, ki delujejo proti nastajanju novih vrednot.

Kotterjev model je obsežnejši od ostalih procesnih modelov. Proces spreminjanja obravnava zelo podrobno in vključuje mnoge strategije: pripravo vizije, izgradnjo vodilnega tima, opolnomočenje zaposlenih ter komunikacijo. Izkazal se je za izjemno uporabnega, saj obravnava tudi psihološki vidik udeleženih v procesu spremembe. 


\section{Burke-Litwinov model}

Organizacija je odprt sistem, kar pomeni, da deluje v okolju, ki ima nanjo večji ali manjši vpliv. $V$ enem izmed predhodnih poglavij smo ugotovili, da pretežni del zahtev po spremembah (prožilcev) prihaja iz zunanjega okolja, ki jih mora management ustrezno ovrednotiti, implementirati in pretvoriti v izboljšane rezultate, te pa na koncu v primerni obliki ponuditi uporabnikom ali drugim deležnikom. Burke in Litwin (1992, v Burke 2002, 199) sta razvila celovit model managementa sprememb, v katerega sta vključila odprtost organizacijskega sistema, ki sta jo prikazala preko povratne zanke. Model prikazuje slika I 2.

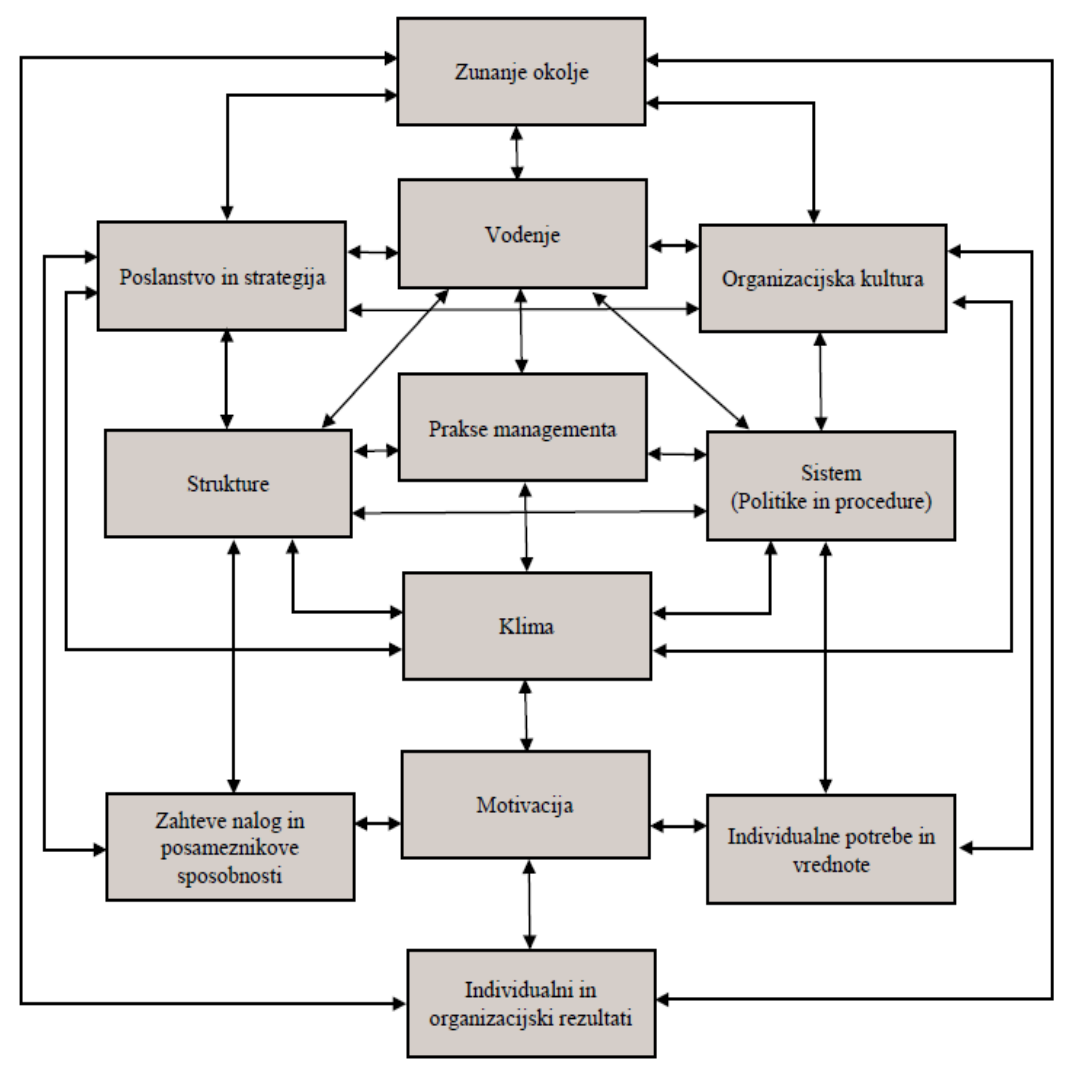

Slika I2: Burke-Litwinov model managementa sprememb

Vir: Burke 2002, 199. 
Model izhaja iz prakse in vsebuje dvanajst ključnih elementov z njihovimi vzročno- posledičnimi povezavami. Zunanje okolje predstavlja vhodno dimenzijo (angl. input), individualni in organizacijski rezultati pa predstavljajo izhodno dimenzijo (angl. output). Zunanje okolje je preko povratne zanke povezano z organizacijskimi rezultati. Puščice povratne zanke kažejo v obe smeri, kar pomeni, da organizacijski rezultati (storitve, proizvodi) vplivajo na zunanje okolje - npr. zadovoljstvo strank -, kar pa zopet vpliva na delovanje organizacije. Preostali elementi predstavljajo področja, o katerih je treba razmišljati in jih analizirati. Tudi tu puščice potekajo $\mathrm{v}$ obe smeri, kar pomeni, da sprememba katerega koli elementa vpliva na preostale elemente. $\mathrm{V}$ modelu so prikazane samo najpomembnejše povezave, ne pa vse možne, kar predstavlja omejitev tega dvodimenzionalnega prikaza.

Model je zanimiv tudi $\mathrm{z}$ vidika razlikovanja transformacijskega in transakcijskega vodenja. Kategorije $\mathrm{v}$ zgornji polovici modela (zunanje okolje, vodenje, poslanstvo in vizija, organizacijska kultura) predstavljajo transformacijske dejavnike. Prikazuje jih slika I3. Interakcija z zunanjim okoljem povzroča spremembo vedenja članov organizacije, kar pa posledično vpliva na spremembo ostalih dejavnikov. Sprememba katerega koli dejavnika vpliva na celoten sistem - takšna sprememba pa je po svoji naravi revolucionarna oz. radikalna in zahteva vizionarsko vodenje.

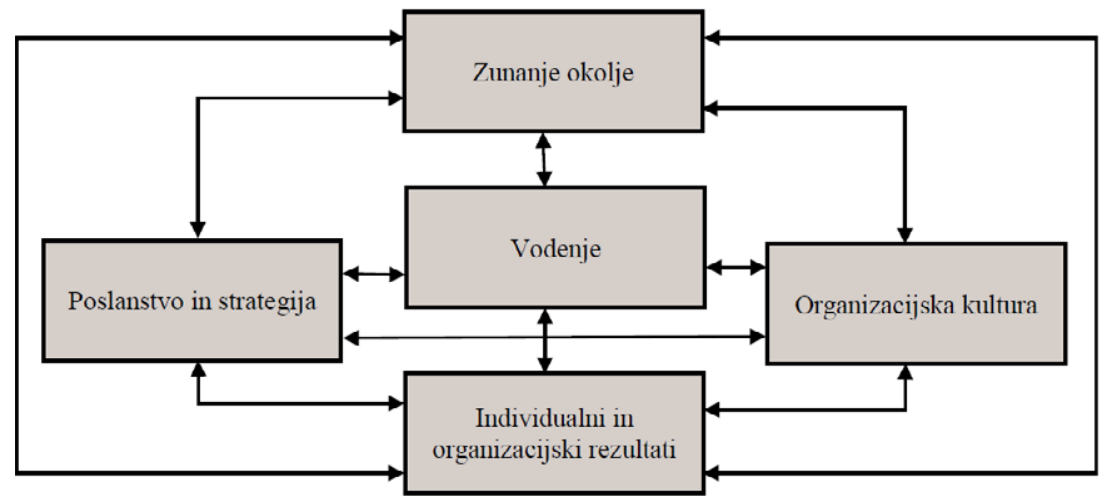

Slika I 3 : Transformacijski dejavniki

Vir: Burke 2002, 202.

Spodnja polovica modela predstavlja transakcijske dejavnike. Prikazuje jih slika I 4. Ti dejavniki so povezani z vsakodnevnimi aktivnostmi v organizaciji. Avtor (Burke 2002, 202) jih imenuje transakcije. Če jih povežemo s terminologijo managementa sprememb, potem pomenijo evolu- 
cijo, kontinuirano izboljševanje vseh praks, aktivnosti in dejavnosti znotraj organizacije.

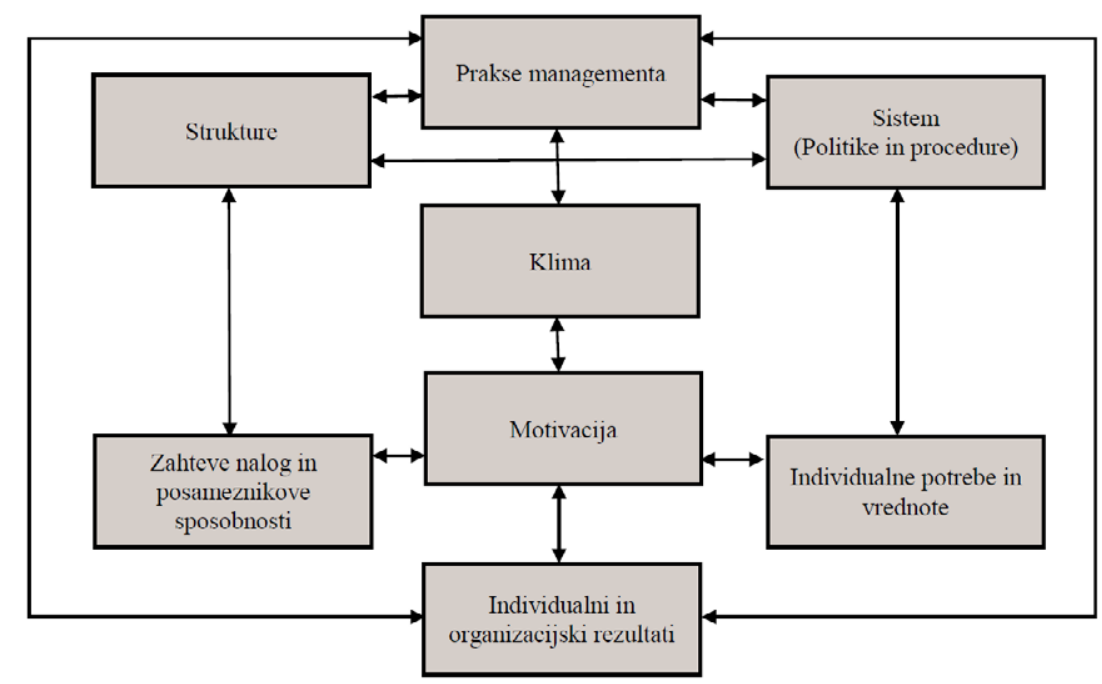

Slika i 4: Transakcijski dejavniki

Vir: Burke 2002, 203.

Model prikazuje, da je transformacijska sprememba tesneje povezana s procesi vodenja, transakcijska sprememba pa s procesi managementa, skladno z razlikovanjem med managementom in vodenjem, ki smo ga prikazali v razdelku 2.I. Transformiranje organizacije zahteva vodjo, ki se s spremembo osebno identificira in ne razlikuje med lastno in organizacijsko vizijo. Transakcijska sprememba pa zahteva managerje, ki se pri svojem delu osredotočajo na nenehno izboljševanje in kvaliteto, bolj kot pa na celoten sistem. Pozitivna sprememba transformacijskih dejavnikov bo povzročila revolucionarne spremembe, pozitivna sprememba enega ali več transakcijskih dejavnikov pa bo povzročala evolucijo oz. nenehno izboljševanje.

Spremenljivke zunanjega okolja, ki močno vplivajo na delovanje organizacije, so številne. Med pomembnejše lahko uvrstimo: vedenje strank, pogoje na trgu, politično ozadje, vladne regulative, svetovne finančne in ekonomske razmere ter spreminjajočo se tehnologijo. Vizija je slika organizacijske prihodnosti in je trdno povezana s ključnimi organizacijskimi kompetencami. Struktura pomeni zgradbo organizacije oz. ureditev organizacijskih funkcij, kot so: računovodstvo, proizvodnja, upravljanje $s$ 
človeškimi viri, nabava idr. Sistemi pa so politike in procedure, ki pomagajo članom organizacije pri njihovih zadolžitvah. Sem štejemo: informacijske sisteme, tehnologijo, sisteme nagrajevanja in različne kontrolne sisteme. Klima je kolektivno zaznavanje zadovoljstva (percepcija članov) znotraj organizacijske enote, tj. zadovoljstva z odnosi, s komunikacijo, z delovnimi pogoji, vodenjem, nagrajevanjem idr. Med transakcijskimi dejavniki je odločilna motivacija. Model služi kot pomoč oz. neke vrste navigacija pri implementaciji načrtovane spremembe. Prikazuje procesni pristop, ki pomaga odgovoriti na vprašanje, »kako izvajati spremembo «. Lahko ga uvrščamo med uporabnejše modele v praksi.

\section{Strategije managementa sprememb}

Značilnost učinkovitih organizacij je, da prekašajo svojo konkurenco in v svoji dejavnosti postavljajo merila odličnosti, kar je posledica njihovega stalnega izboljševanja in napredka. Blanchard in Waghorn (1996, 5060) med drugim navajata pet bistvenih značilnosti učinkovitih organizacij: (I) najpomembnejša je stalen napredek oz. stalno izboljševanje, ki mora temeljiti na nenehnem učenju organizacije; (2) zavzeti in usposobljeni zaposleni; (3) navdušene in zveste stranke; (4) finančna uspešnost, brez katere organizacija ne more preživeti, in ( 5 ) doslednost pri poudarjanju pomena zadovoljnih strank in zaposlenih ter pozitivnih finančnih rezultatov. Stalen napredek pomeni nenehno spreminjanje. Spremembe pa povzročajo probleme, ki jih je treba reševati (Adizes 1996, 19). Avtor (prav tam) pravi, da gre pri obvladovanju sprememb za dva procesa. Prvi je sprejemanje dobrih odločitev, drugi je udejanjanje teh odločitev. Pri udejanjanju vodje uporabljajo mnoge strategije vplivanja na zaposlene. $S$ svojo držo, dejanji in odnosom do spremembe opogumljajo zaposlene, da prevzemajo nova vedenja (načine dela), ki vodijo $\mathrm{k}$ boljšim organizacijskim dosežkom. $Z$ redno in poglobljeno komunikacijo pridobivajo zavzetost zaposlenih. Pred tem pa morajo izoblikovati razumne razlage in biti pripravljeni na odpore.

Strateška sprememba zahteva veliko časa in priprave (Pasmore 1994, 245). Strategije, ki jih avtor predlaga, opisujemo spodaj.

- Priprava: od managerja sprememb zahteva dobro razumevanje trenutne in prihodnje situacije. Prvi korak pri razumevanju je lahko izvedba primerjalne študije (angl. benchmarking) ali izvedba strateške konference, kjer udeleženci ocenijo stanje, v katerem je organizacija. Možen je tudi pregled poslovnih poročil zadnjih let, s katerim lahko ugotovimo, kako zdrava je organi- 
zacija; čeprav je boljša skupna konferenca, kjer se že lahko poraja in pojasni potreba po spremembi. Skupno srečanje nudi tudi priložnost za participacijo zaposlenih. Priprava ljudi poteka na mnoge načine. Zaposleni bodo morda potrebovali nova znanja in veščine. Potrebno jih bo usposabljati v različnih izobraževalnih oblikah, kot so interna usposabljanja, formalna izobraževanja, usposabljanja na delovnem mestu ali obisk tuje ustanove. V fazi priprave je na spremembo treba pripraviti tudi ostale deležnike: nadzornike, stranke, dobavitelje idr. Delo z njimi zahteva mnogo dogovarjanj, morda celo pogajanj. Vzeti si čas za dobro pripravo je dobra odločitev, ki olajša nadaljnje korake.

- Analiza prednosti in slabosti: organizacija se mora primerjati s standardi, ki veljajo za njeno panogo, in v okviru tega ugotoviti svoje prednosti in slabosti, kar ji običajno že predstavlja dobro izhodišče za izboljševanje. $V$ tej fazi si postavi cilje za izboljšanje in kriterije, po katerih jih bo merila.

- Postavitev novih organizacijskih struktur: ko so preliminarne analize končane, se lahko izvedejo spremembe $\mathrm{v}$ strukturi organizacije. $V$ tej fazi procesa spreminjanja je treba postaviti fleksibilne organizacijske strukture, ki bodo podpirale in olajševale želene spremembe. To lahko storimo s povečevanjem zmožnosti posameznikov in zmožnosti organizacijskih enot. Novonastale organizacijske enote in podenote je na koncu treba povezati v sistem.

- Načrtovanje projektov: sprememba se dogaja skozi različne manjše projekte. Pomembno je, da so v tej fazi vključeni vsi zaposleni. Načrtovati je treba vse potrebne vire, aktivnosti in roke. Naloge načrtovanja opravlja tim ključnih oseb, ki niso samo iz vrst zaposlenih, ampak so tudi ostali - stranke ter ostali deležniki. Število vključenih v projekt spremembe je lahko zelo veliko. Kompleksnejši kot je projekt, večjo organizacijsko fleksibilnost zahteva.

- Gradnja sistemov: v tej fazi je znotraj glavnega projekta delo opravljeno; ideje so razvite, proizvodi oz. storitve pripravljeni. Uporablja se nova tehnologija, med člani organizacije se postavljajo nove vloge. Treba je meriti in nadzorovati nove načine izvajanja dela, od strank prejemati povratne informacije ter jih upoštevati pri nadaljnjih izboljšavah. Gradnja sistemov zahteva premišljeno vpeljavo komunikacijskih in integracijskih mehanizmov. 
- Izgradnja podpornih sistemov: ko so sistemi dela znotraj enot postavljeni, je treba zgraditi podporne sisteme. Ekonomsko najbolj upravičene so centralizirane podporne storitve.

- Integracija: v tej fazi je treba vse nove strukture in sisteme povezati v delujočo celoto. Aktivnost poteka skozi zbiranje in razširjanje potrebnih informacij.

- Uvajanje spremembe: vsaka sprememba zahteva čas, zato je načrtovanje spremembe lahko odločilnega pomena. Načrtovanje pomaga razjasniti naloge, ki morajo biti narejene $\mathrm{z}$ vsemi potrebnimi roki in viri. Dober načrt je kot kažipot, ki omogoča preverjanje odmikov in njihovo sprotno uravnavanje. Če so indikatorji spremembe dobro začrtani, je implementacija bistveno olajšana.

Pasmore (1994) omenjene pristope imenuje strategije, čeprav celoto vseh korakov oz. faz lahko obravnavamo kot procesni model managementa strateških sprememb.

Lockitt $(2004,4-5)$ povzema pet pristopov in strategij managementa sprememb, opisanih spodaj.

- Direktivna strategija: pri njej manager uporabi avtoriteto. Zaposlene v odločanje vključuje zelo malo, spremembo skorajda vsili. Prednost tega pristopa je v hitrosti uvedene spremembe. Njegova slabost pa je v tem, da ne upošteva mnenj, pogledov ter občutkov zaposlenih. Na ta način se izgubi mnogo dragocenih idej in informacij.

- Ekspertna strategija: pristop se zdi podoben procesu reševanja problemov. Primernejši je za tehnične probleme. Običajno ga vodi projektni tim specialistov ali glavni manager. Eksperti imajo glavno vlogo pri rešitvah, ki so lahko hitro uvedene. Lahko se zgodi, da drugi vpleteni teh rešitev ne cenijo, saj so jim nekako vsiljene, ali pa imajo popolnoma drugačen pogled nanje.

- Strategija pogajanj: ta pristop osvetli pripravljenost dela najvišjega managementa, da se pogaja in »kupčuje « v smislu učinkovitega uvajanja spremembe. Vključeni v pogajanja imajo možnost povedati in uveljaviti svoj vidik (katere spremembe in kako se bodo implementirale ter kakšni bodo pričakovani rezultati). Slabost pristopa je, da zahteva več časa, rezultati niso vedno predvidljivi in sprememba ne zadovolji pričakovanj vseh vanjo vključenih ljudi. Prednost je vsaj ta, da se bodo posamezniki počutili vključene in bodo spremembo tudi podprli. 
- Strategija izobraževanja: pristop vključuje spreminjanje vrednot in prepričanj z namenom, da se doseže popolna podpora za spremembe, in pomeni premike $\mathrm{k}$ razvoju skupnih vrednot, ki so jih ljudje pripravljeni in zmožni podpreti. Pri tej strategiji je uporabljena mešanica aktivnosti in izobraževalnih metod, kot so prepričevanje, izobraževanje, treningi in svetovanja zunanjih specialistov ter notranjih ekspertov. Slabost pristopa je v porabi časa. Prednost pa je, da bodo ljudje zavzeti za spremembo.

- Participativne strategije: pri tem pristopu je poudarek na popolni vključenosti zaposlenih, ki jih sprememba zadeva. Management ne vsiljuje svojih pogledov, pred uvajanjem se uskladijo pogledi vseh. $\mathrm{V}$ procesu usklajevanja lahko pomagajo zunanji svetovalci. Od vseh predstavljenih pristopov participativni zahteva največ časa in stroškov, kar je njegova slabost. Prednost pa je v zavzetosti zaposlenih, celo več: zaposleni čutijo »lastništvo « nad spremembami in jih popolnoma sprejmejo za svoje.

Čeprav so vse strategije predstavljene ločeno oz. neodvisno, pa se v praksi običajno prepletajo. Veščina učinkovitega managerja sprememb je ravno ta, da prepozna, katero strategijo je pametno uporabiti in kako. Opisane strategije so primerne tudi v okolju zdravstvenih ustanov, vendar pa zanje $\mathrm{v}$ tem primeru veljajo določene specifike, ki smo jo zasledili v literaturi in jo predstavljamo $v$ nadaljevanju.

\section{Strategije organizacijskih sprememb v zdravstvu}

Zaposleni v zdravstvu se radi učijo na primerih dobrih praks. Rutledge in Sinclair $(2013,70)$ menita, da so ključni dejavniki uspeha sprememb v zdravstvu: vključevanje ljudi v spremembe, zadostna komunikacija, poudarjanje zgodnjih uspehov in zasidranje spremembe v skupinsko kulturo. Avtorja sta prepričana, da je najpomembnejši faktor uspeha pri uvajanju sprememb dogovor z zdravniki, ki mora vsebovati: njihovo zgodnjo vključitev v spremembo, upoštevanje njihovih časovnih razpoložljivosti, primerno (razumno) uporabo podatkov, povezanost predlagane spremembe z izboljšavami za paciente, apel na njihovo individualno odgovornost in vključevanje neformalnih vodij v spremembo. Tudi LeTourneau in Fleischauer (1999, I2) ugotavljata, da sta avtonomija in osebna odgovornost pomembni značilnosti zdravniškega poklica, zato ju ne kaže spregledati.

Menaker $(2009,342)$ je iz obsežne literature o vodenju izluščil štiri najpomembnejše strategije. Prva se nanaša na določitev jasne vizije, druga je osredotočanje na prioritete in odnose, tretja je krepitev razumeva- 
nja spremembe, četrta pa se nanaša na krepitev zaupanja v spremembo. Meni, da je slednja vitalnega pomena. Pomey idr. (2004, I17) pa med pomembne strategije uvrščajo diseminacijo (širjenje vizije in vseh vrst informacij o spremembi) ter organizacijsko učenje.

\begin{tabular}{|c|c|c|c|}
\hline $\begin{array}{c}\text { Dimenzije } \\
\text { spreminjanja }\end{array}$ & Teorija E & Teorija $\mathbf{O}$ & Teorija EO \\
\hline Namen & $\begin{array}{c}\text { Maksimiranje ekonomske } \\
\text { vrednosti }\end{array}$ & $\begin{array}{l}\text { Razvoj organizacijskih } \\
\text { sposobnosti }\end{array}$ & $\begin{array}{l}\text { Sprejemanje paradoksa } \\
\text { med E- in O-teorijo }\end{array}$ \\
\hline Vodenje & Od zgoraj navzdol & Participativno & $\begin{array}{l}\text { Nastavitev smeri iz vrha in } \\
\text { omogočanje participacije }\end{array}$ \\
\hline Osredotočenje & Strukture in sistemi & Kultura & Osredotočenje na oboje \\
\hline Proces & Programiran & $\begin{array}{c}\text { Spontan - eksperiment in } \\
\text { razvoj }\end{array}$ & Načrtovanje in spontanost \\
\hline Sistem nagrad & Nagrade usmerjajo & Nagrade sledijo & $\begin{array}{l}\text { Nagrade kot spodbuda, ne } \\
\text { kot glavno gonilo }\end{array}$ \\
\hline Svetovanje & $\begin{array}{c}\text { Obsežno in splošno } \\
\text { usmerjeno }\end{array}$ & $\begin{array}{c}\text { Majhno in procesno } \\
\text { usmerjeno }\end{array}$ & $\begin{array}{l}\text { Svetovalci so eksperti, ki } \\
\text { opolnomočijo zaposlene }\end{array}$ \\
\hline
\end{tabular}

Slika i s: Teorije organizacijskih sprememb

Vir: Beer in Nohria 2000, 137.

Steinke idr. (20I3) so v svoji študiji preučevali načine, s katerimi bi lahko zdravstvena organizacija izboljšala svojo pripravljenost in zmožnosti za spreminjanje $\mathrm{z}$ uporabo teorije $\mathrm{E}$ in teorije $\mathrm{O}$, katerih avtorja sta Beer in Nohria (2000). Teorija E se osredotoča na ekonomsko vrednost spremembe, teorija $\mathrm{O}$ pa na dolgoročne organizacijske zmožnosti, tj. na človeške zmožnosti organizacije. Obe teoriji gradita na šestih dimenzijah spreminjanja (Beer in Nohria 2000, 137). Razlike v osnovnih gradnikih posamezne teorije prikazuje slika Is. Vsaka teorija ima svoje prednosti in omejitve. Avtorja pravita, da je organizacija najuspešnejša, če uporablja kombinacijo obeh teorij, ki sta jo poimenovala teorija EO. Istočasno upoštevanje obeh teorij je zelo težko, vendar je pri uvajanju sprememb tudi najuspešnejše. Steinke idr. (2013, I34) v raziskavi pokaže, da uporaba teorije E izboljša pripravljenost zdravstvene organizacije za spreminjanje, kar avtorja pripisujeta prevelikemu poudarku na ekonomiki in obvladovanju stroškov $\mathrm{v}$ zdravstvu s strani politike in medijev ter premajhnemu poudarku na drugih vidikih. Huy (2001, 604) predlaga, da organizacija 
izbere teorijo $\mathrm{E}$ ali teorijo $\mathrm{O}$ glede na določljivost vsebine spremembe in vrsto spremembe. $\mathrm{V}$ primeru, da je vsebina določena in je sprememba občasna, predlaga uporabo teorije E. Pristop naj bo osredotočen na formalne strukture in $\mathrm{z}$ direktivnim načinom vodenja. $\mathrm{V}$ primeru kontinuirane spremembe naj management prav tako uporabi teorijo E, osredotoči pa naj se na delovne procese. Če je vsebina spremembe nedoločljiva, kot so npr. prepričanja in odnosi, potem v primeru občasne spremembe (prepričanja) predlaga poučevanje; v primeru kontinuirane spremembe (odnosi) predlaga socializacijo.

Rees (2014) je na primeru treh urgentnih centrov raziskoval proces uvajanja vitke organizacije oz. vitkega razmišljanja (angl. lean thinking), ki so ga v letih 2008-2010 implementirale novozelandske bolnišnice. Vitko razmišljanje $\mathrm{v}$ zdravstveno organizacijo $\mathrm{s}$ svojimi orodji uvaja filozofijo oz. sistem, ki pomaga zmanjšati število strokovnih napak, izboljšati kvaliteto zdravstvene oskrbe in zmanjšati čakalne dobe za bolnike (Rees 2014, 2). Omenjena vitkost je sestavni del nenehnega izboljševanja bolnišničnih praks. Ugotovitve kvalitativne raziskave kažejo na nujno potrebno vključenost: (I) zdravnikov v primeru uvajanja takšnih fundamentalnih sprememb in (2) najvišjega vodstva. Brez enih ali drugih so rezultati uvajanja sprememb slabi ali pa jih sploh ni.

\section{Strategije za zmanjšanje odporov}

Manager sprememb se nujno srečuje z odpori. Razloge za odpore smo predstavili v drugem poglavju, $\mathbf{v}$ pričujočem pa želimo prikazati osnovne strategije za njihovo zmanjševanje.

Pennington $(2003,9)$ predlaga naslednje strategije:

- podajanje bogatih informacij, izobraževanje in ciljno komunici-

ranje;

- povečati možnosti za participacijo in vključevanje (delovne skupine, delovne zabave);

- treningi za izgradnjo zaupanja in kompetenc;

- prepričevanje in pogajanja za določitev skupnih temeljev;

- omejevanje »razčiščevanj《 in direktnih spopadov.

Tudi Lockitt $(2004,9)$ poleg komunikacije, izobraževanja in pogajanja predlaga nekaj načinov, ki prispevajo $\mathrm{k}$ zmanjševanju odporov (avtor jim pravi opozicija). Odsvetuje uvajanje nepotrebnih sprememb. Dobro je treba prisluhniti razlogom, ki so proti spremembam. Manager sprememb se mora vedno prepričati, da ljudje vedo, zakaj je sprememba potrebna. $\mathrm{Za}$ zaposlene, ki so vključeni v spremembo, predlaga participacijo pri odlo- 
čitvah in čimprejšnjo vključitev v proces spreminjanja. Managerjeva naloga je tudi zgraditi podporne skupine in povezave ter delati s ključnimi ljudmi znotraj organizacije. Predvsem pa je treba ves čas poudarjati, kaj se bo zgodilo v primeru, da se sprememba ne uvede.

Burke $(2002,260) \mathrm{k}$ vsem omenjenim dejavnostim managementa dodaja še potrebno vztrajnost $\mathrm{z}$ jasno usmeritvijo, ki naj jo podkrepi $s$ strastjo in vizijo. Vsi odpori niso nujno negativni (Paton in McCalman 2000, 49). Lahko na primer signalizirajo, da implementacija spremembe ne bo prispevala k skupni blaginji. 



\section{Model izvajanja sprememb v bolnišnicah}

Spoznanja literature s področja vodenja kažejo na dejstvo, da je vodenje sprememb ena najpomembnejših in težkih vodjevih odgovornosti. Učinkovito vodenje mora revitalizirati organizacijo in olajševati njeno prilagajanje na spreminjajoče se okolje (Yukl ı998, 438). Ugotovili smo že, da je sprememba proces in ne dogodek. Njena uspešna izvedba je odvisna od vodjevega razumevanja odporov, posameznih faz $\mathrm{v}$ procesu spreminjanja in različnih strategij spreminjanja.

$\mathrm{V}$ prejšnjih poglavjih smo spoznali različne vrste sprememb, prav tako smo predstavili različne stile vodenja ter nekatere modele managementa sprememb. V tem poglavju predstavljamo nekaj pristopov $k$ vodenju različnih vrst sprememb (inkrementalnih in fundamentalnih). $\mathrm{Na}$ osnovi preučitve teoretičnih izhodišč postavimo konceptualni model stilov vodenja glede na vrsto spremembe, ki ga v nadaljevanju razširimo v celovit koncept teoretičnega modela izvajanja sprememb v bolnišnicah.

\section{Povezava med stili vodenja in vrstami sprememb}

V literaturi je zaslediti povezanost različnih pristopov oz. stilov vodenja s posameznimi vrstami sprememb. Hussey (1995, I4-16) vodjem sprememb predlaga, da so pozorni na dva dejavnika: na nujnost spremembe in odpore. Večja kot je nujnost spremembe, manj sproščen pristop bo potreben. Pristop narekuje tudi vrsta spremembe. Po njegovem mnenju je treba preučiti, kakšne so veščine in zmožnosti tistih, na katere bo sprememba vplivala. Če so majhne, potem participacija ni najprimernejši pristop, treba jo je zamenjati z zadostno formalno komunikacijo. Vprašati se je treba, 
ali so ljudje motivirani za participacijo. Tudi če so odpori majhni, nekateri ne želijo aktivno sodelovati pri odločanju o tem, kako uvajati spremembo. Pomembno je preučiti, ali je predlagan pristop skladen $s$ kulturo v organizaciji. Če ni, je včasih bolje prilagoditi pristop. Na primer: široka participacija lahko povzroča sumničavost $\mathrm{v} \gg$ šefovskih « organizacijah, $\mathrm{v}$ katerih vlada strah, diktatorski pristop pa lahko demotivira organizacijo, ki je običajno participativna. Fundamentalna (strateška, tudi transformacijska) sprememba običajno zahteva spremembo kulture. Način implementacije mora upoštevati stare in nove vrednote. Ugotoviti je treba, koliko zaupanja v spremembo je med zaposlenimi, ter pridobiti njihovo lojalnost in vzdrževati motivacijo.

Slika 16 prikazuje ustrezne pristope glede na intenzivnost odporov in nujnost uvajanja sprememb v primeru inkrementalne spremembe.

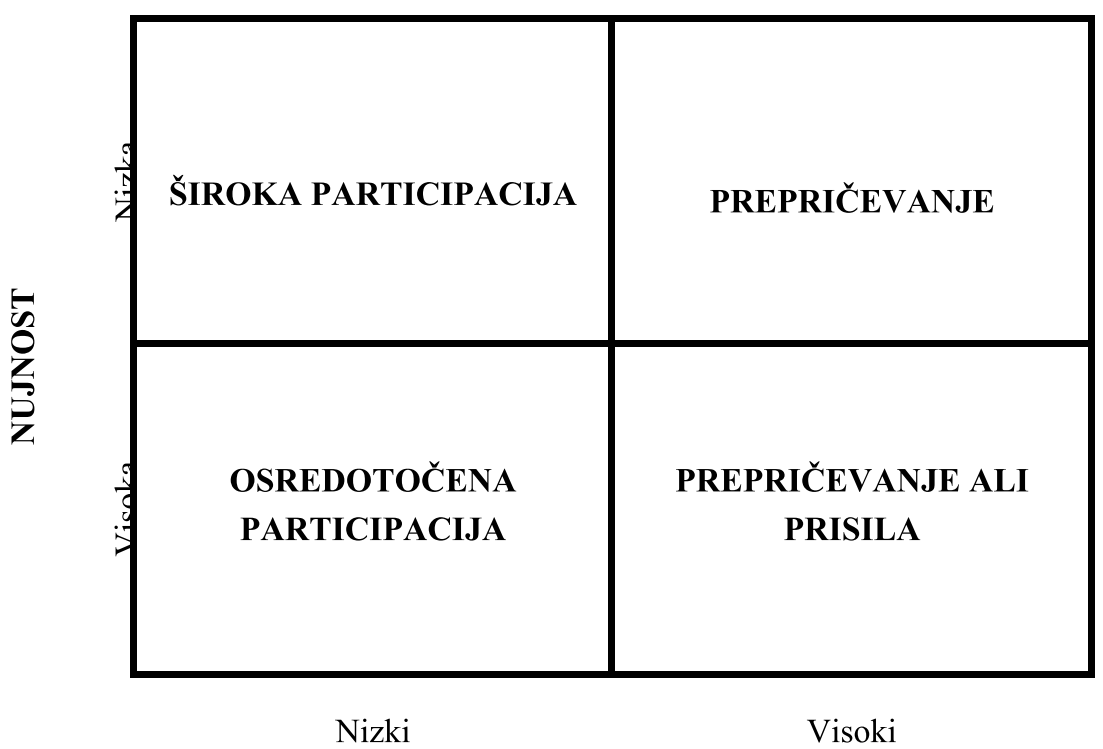

ODPORI

Slika ı 6: Pristopi k spreminjanju v primeru inkrementalne spremembe Vir: Hussey 1995, 17.

Široka participacija pomeni dopuščati zaposlenim, da odločajo o pristopu. $S$ tem se poveča motivacija za spremembo. Pojavi se dilema managementa sprememb, da ne bi bil preveč direktiven, oz. kako zagotoviti, da bo participacija učinkovita oz. da predolga diskusija ne bo nadomestilo za potrebno akcijo. $V$ primeru nujnosti spremembe in nizkih odpo- 
rov zadošča osredotočena oz. delna participacija. Potrebno je identificirati ključne ljudi in doseči njihovo participacijo, istočasno pa zagotoviti jasno komunikacijo z ostalimi vpletenimi. Manager mora določiti ključne ljudi in doseči, da sprejmejo rešitev. Pri visokih odporih in majhni nujnosti je lahko primeren pristop prepričevanje oz. »prodajanje « koncepta, čeprav je razglašanje skupne vizije kot posledice spremembe še primernejši. »Prodajanje « lahko vodi v razočaranje, če obljubljene koristi niso realizirane, kar poveča odpore. $\gg$ Prodaja « je obljuba, skupna vizija pa postane notranja motivacija. Nekateri ljudje pa se ne dajo prepričati, ker so v svojih pogledih zelo ozki. K njim je potrebno pristopiti na način prisile. Dobijo inštrukcije in v primeru, da naloge niso narejene, sledijo sankcije.

Ustrezne pristope $\mathrm{v}$ primeru fundamentalne spremembe prikazuje slika 17. Ko uvajamo fundamentalno spremembo, je potrebno preučiti več stvari. Po njeni uvedbi organizacija postane drugačna, se temeljito spremeni. Težko govorimo o nenujnosti fundamentalne spremembe - fundamentalna sprememba je vedno nujna. Če ni, potem je organizacija v krizi.

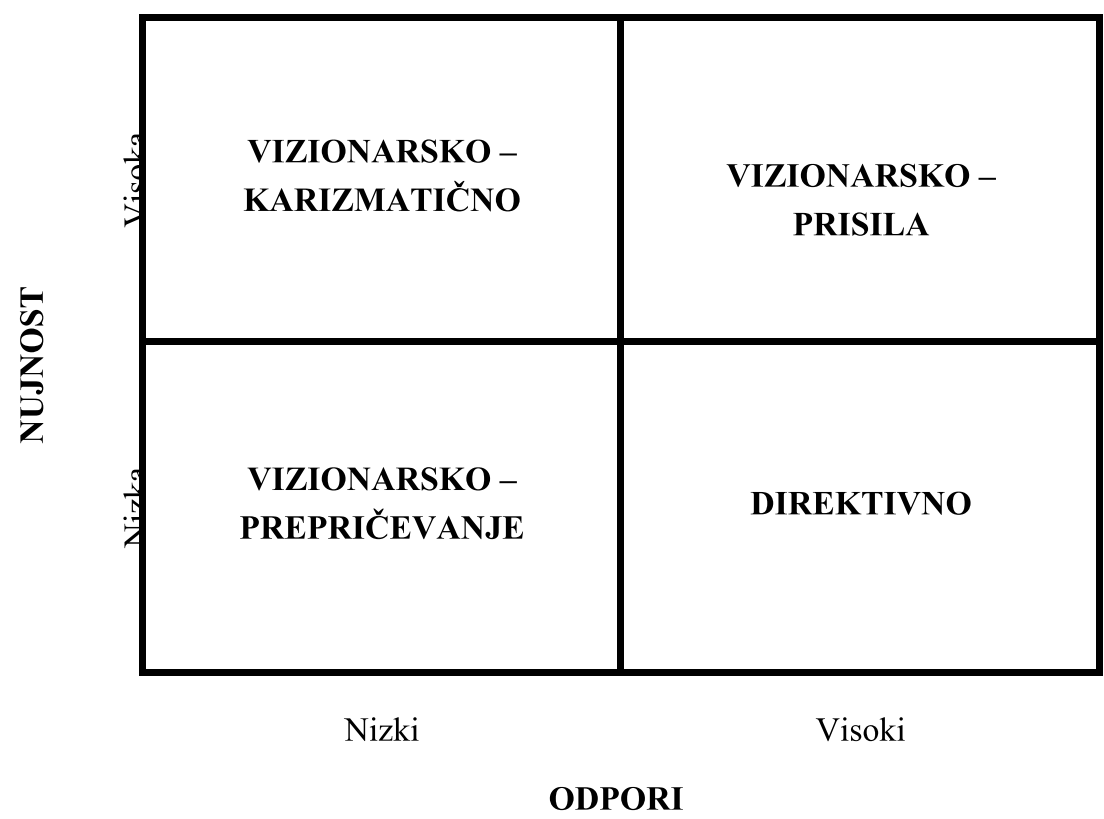

Slika i 7: Pristopi k spreminjanju v primeru fundamentalne spremembe Vir: Hussey 1995, 20. 
$\mathrm{V}$ primeru fundamentalne spremembe je skupna vizija nujna. Hussey $(\mathrm{I} 995,2 \mathrm{I}) \mathrm{v}$ primeru nizke nujnosti in nizkih odporov predlaga vizionarsko vodenje s poudarkom na prepričevanju. Pomembno je doseči skupno vizijo in prepričati zaposlene, da je začrtana smer ustrezna in da se je zanjo vredno potruditi. Ko je nujnost visoka in odpori nizki, lahko manager uporabi svoje karizmatične lastnosti. Zaupanje v takega vodjo je veliko, zato v organizaciji vlada entuziazem. Karizma sama po sebi pa ne povzroča fundamentalne spremembe.

Ko so odpori visoki in nujnost velika, je prisila najboljši pristop. Časa za prepričevanje ali široko participacijo ni na razpolago. Poudarek na viziji pa je prav tako pomemben kot $\mathrm{v}$ prejšnjih dveh primerih. $Z$ vizijo vodje pri ljudeh ustvarijo občutek, da vedo, kaj želijo doseči. V primeru nizke nujnosti in visokih odporov je najprimernejši pristop direktivno vodenje.

Griffith-Cooper in King $(2007,17)$ prav tako predlagata, da naj vodja izbere strategijo in taktike za uvajanje sprememb glede na velikost in kompleksnost spremembe. Organizacijske spremembe obravnavata s procesnega vidika in jih predstavita $\mathrm{v}$ obliki kontinuuma spreminjanja, pri čemer so razvojne spremembe na najnižjem nivoju kontinuuma sprememb. To so majhne, manj moteče spremembe v procesih. Tranzicijske spremembe predstavljajo nadgradnjo razvojnih in predstavljajo nekoliko večje motnje. Transformacijske spremembe pa povzročajo največje motnje in zahtevajo temeljite spremembe organizacijske kulture ter vedenj zaposlenih (Griffith-Cooper in King 2007, 17). Vrsta (nivo) spremembe določa tudi njeno vodenje. Pri transformacijskih spremembah je vodenje najzahtevnejše, kar je nakazano na sliki 18.

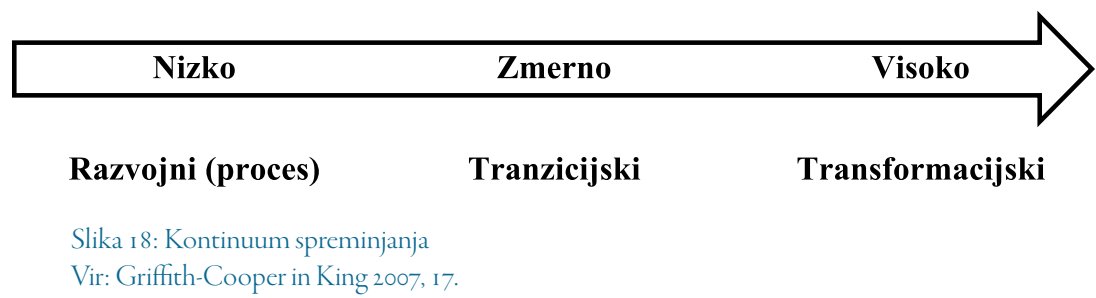

Burke (2002, I2) razpravlja o različnih pristopih glede na vrsto spremembe. Pravi, da revolucionarne oz. radikalne spremembe vplivajo na celotno organizacijo in zahtevajo dramatične modifikacije poslanstva ali strategije. Zahtevajo drugačne pristope kot kontinuirana sprememba. 


\section{Konceptualni model}

Tudi v našem teoretičnem konceptualnem modelu predvidevamo, da lahko k posameznim vrstam sprememb pristopamo različno. Pri tem izhajamo iz osnovne tipizacije oz. kategorizacije sprememb po Penningtonu $(2003,6)$, ki se nam zdi uporabna v zdravstvenih organizacijah.

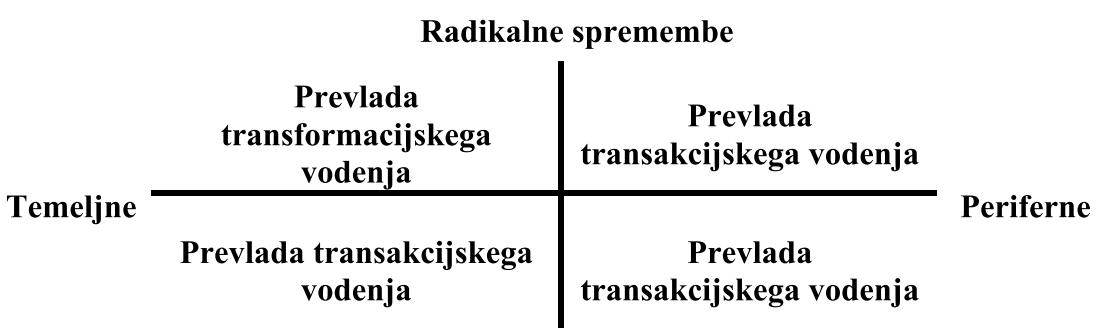

Inkrementalne spremembe

Slika 19: Konceptualni model stilov vodenja glede na vrsto spremembe

Domnevamo, da je lahko pri uvajanju radikalno perifernih, inkrementalno temeljnih in inkrementalno perifernih sprememb uspešen že transakcijski stil vodenja, pri radikalno temeljnih spremembah pa ga je treba nadgraditi s transformacijskim stilom vodenja. Konceptualni model stilov vodenja glede na vrsto spremembe prikazuje slika 19. Spoznali smo že, da je transakcijsko vodenje podobnejš »šefovskemu « načinu vodenja, pri katerem med vodjo in zaposlenimi potekajo t. i. »transakcije «. Vodja razdeli naloge in nadzira rezultate, pri čemer uporablja dobro poznano metodo »korenčka in palice «. Ve, kaj njegove sodelavce motivira, zato jih za dobro opravljeno delo nagradi, prav tako pa tudi kaznuje, če ni rezultatov. $S$ tem se njegov vodstveni repertoar zaključi. Transformacijsko vodenje pa tehnike in pristope $\mathrm{v}$ okviru transakcijskega načina vodenja nadgrajuje $\mathrm{v}$ smislu boljšega in učinkovitejšega dela $\mathrm{z}$ ljudmi. Transformacijski vodja ljudi motivira skladno z njihovimi vrednotami (ne zgolj finančno), skrbi za razvoj sodelavcev, jih vključuje $\mathrm{v}$ postavljanje vizije in odločanje. Na ta način mu uspeva preoblikovati (transformirati) zaposlene in celotno organizacijo. Zato menimo, da transformacijsko vodenje prevladuje pri radikalnih spremembah temeljnih procesov, transakcijsko vodenje pa prevladuje pri ostalih treh koncipiranih vrstah sprememb.

Na podlagi podrobnega pregleda ustrezne literature postavljamo celovit koncept modela izvajanja sprememb v bolnišnicah, ki dopolnjuje primarni konceptualni model stilov vodenja glede na vrsto spremembe. 
Model prikazuje slika 2o. Ključne dejavnike, ki vplivajo na uvajanje sprememb, povezuje $v$ smiselno medsebojno razmerje.

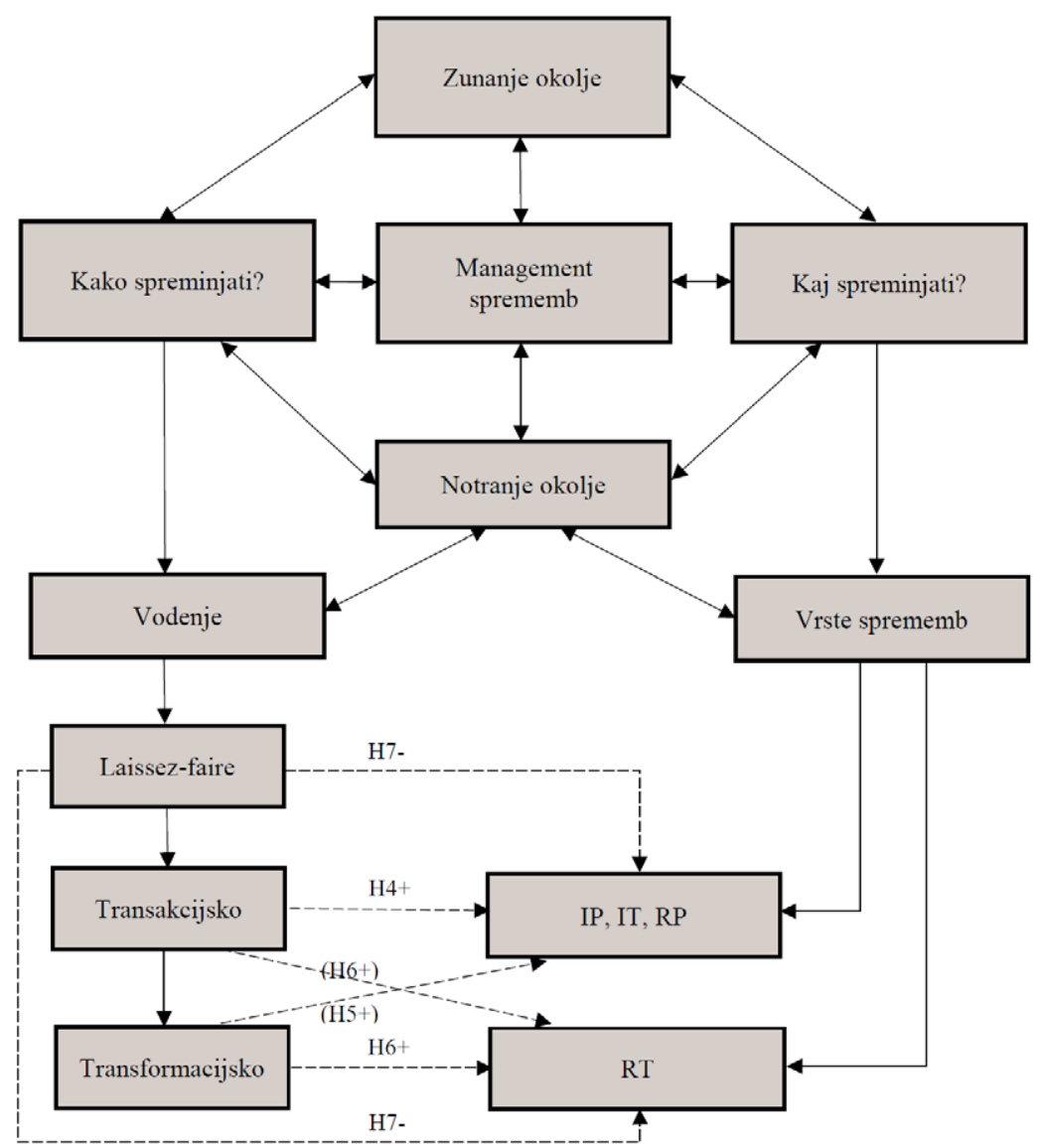

Slika 20: Konceptualni teoretični model izvajanja sprememb v bolnišnicah

Model vključuje procesni vidik spreminjanja (kako spreminjati?) ter vsebinski vidik (kaj spreminjati?). Management sprememb je osrednji dejavnik, ki preko procesov vodenja odloča o načinih oz. pristopih izvajanja sprememb, skozi procese načrtovanja in odločanja pa sprejema in udejanja odločitve glede potrebnih sprememb. Odločitev oz. odgovor na vprašanje, kako bomo izvajali spremembe, določa pristop $k$ vodenju in $s$ tem izbiro stila vodenja. Odločitev oz. odgovor na vprašanje, kaj bomo spreminjali, določa vrsto spremembe. Vrsta spremembe pa zopet narekuje izbiro stila vodenja. Model nakazuje, da so sprožilci sprememb v zunanjem 
in notranjem okolju. Spodnji del modela vsebuje hipoteze naše kvantitativne raziskave, kar je nakazano s črtkanimi povezavami. Hipoteze, kjer predvidevamo manjšo povezanost med spremenljivkami, smo dali v oklepaj, negativno povezanost pa smo označili z minusom.

Bass in Avolio (1995) ponujata celovit model vodenja, ki vključuje tri glavne stile: transformacijskega, transakcijskega in laissez-faire. Naša temeljna hipoteza predpostavlja, da je uspešnost procesa izvajanja sprememb povezana s stilom vodenja. Predpostavljamo, da sta transformacijsko in transakcijsko vodenje pozitivno povezana z zaznano oz. ocenjeno uspešnostjo uvedenih sprememb, vendar transakcijsko vodenje v manjši meri kot transformacijsko; vodenje laissez-faire pa je negativno povezano z zaznano uspešnostjo uvedenih sprememb. Omenjene predpostavke predstavljajo naše prve tri hipoteze $\mathrm{v}$ raziskavi.

Avtorji mnogih študij so ugotavljali vpliv transformacijskega vodenja na izvajanje dela zaposlenih ter usmerjanje slednjih proti želenim vedenjem in ciljem (Xirasagar, Samuels in Stoskopf 2005, 723). Zaslediti je tudi raziskave o pozitivnem vplivu transformacijskega vodenja na organizacijske inovacije (Mokhber, Wan Ismail in Vakilbashi 2014).

$\mathrm{Na}$ osnovi predstavljenih teoretičnih spoznanj stilov vodenja in skladno z opredelitvijo radikalno temeljnih, radikalno perifernih, inkrementalno temeljnih ter inkrementalno perifernih sprememb smo postavili naslednje hipoteze $\left(\mathrm{H}_{4}-\mathrm{H}_{7}\right)$, ki se navezujejo na naš model, zato jih ponovno izpostavimo:

$\mathrm{H}_{4}$ : Transakcijsko vodenje je pozitivno povezano z IT-, IP- ter s RP-spremembo.

$\mathrm{H}_{5}$ : Transformacijsko vodenje je pozitivno povezano z IT-, IP- ter s $\mathrm{RP}$-spremembo, vendar v manjšem obsegu kot transakcijsko vodenje.

H6: Transakcijsko vodenje je pozitivno povezano z RT-spremembo, vendar v manjšem obsegu kot transformacijsko vodenje.

$\mathrm{H}_{7}$ : Vodenje laissez-faire je negativno povezano $\mathrm{z}$ vsemi štirimi vrstami sprememb. 



\section{Metodološki \\ in konceptualni okvir \\ raziskave}

$\mathrm{V}$ tem poglavju bomo predstavili teoretična metodološka izhodišča raziskave in njen konceptualni okvir. Poglavje namenjamo predstavitvi temeljnih vprašanj za izvedbo polstrukturiranih intervjujev v kvalitativni raziskavi ter anketnega vprašalnika za namene kvantitativne raziskave. Vprašalnik je nastal na podlagi operacionalizacije konstruktov, ki je prav tako tema tega poglavja. Na koncu poglavja opisujemo vzorec raziskave ter metode zbiranja in analiziranja podatkov.

\section{Metodološka izhodišča raziskave}

Metodologija je veda, ki se na normativen način ukvarja $\mathrm{z}$ dejavnostjo znanstvenika, ko ta spoznava predmet svojega dela (Flere 2000, 5i). Metodologija oz. znanstvena metoda je pot oz. način, $s$ katerim pridemo do novega znanstvenega spoznanja. Povezuje teorijo in izkustvo. Obsega vse postopke, ki jih uporabljamo pri raziskovanju pojavov (Toš in Hafner-Fink 1998, I3).

$\mathrm{V}$ raziskavi je uporabljen kombiniran kvalitativno-kvantitativni pristop, zato $\mathrm{v}$ uvodu poglavja o metodologiji ne moremo mimo znanstvenega diskurza o kvalitativni in kvantitativni paradigmi, ki sta se izoblikovali znotraj fenomenološkega in pozitivističnega filozofskega stališča. Kvalitativna metodologija se je razvijala predvsem v okviru fenomenološko interpretativne paradigme, kvantitativna metodologija pa je značilna za pozitivistično znanost. Pozitivisti govorijo o družbeni stvarnosti kot neodvisni od individualne zaznave (Toš in Hafner-Fink 1998, 7) in pravijo, da je opazovana stvarnost neodvisna od raziskovalca (Easterby-S- 
mith, Thorpe in Lowe 2005, 46). Fenomenologi pa poudarjajo, da se realni družbeni svet konstituira šele $\mathrm{v}$ procesu zaznavanja konkretnih družbenih pojavov (Toš in Hafner-Fink 1998, 7) oz. da družbena stvarnost ni objektivna danost, temveč je rezultat dejavnosti ljudi, pri čemer raziskovalec ne zbira zgolj dejstev, ampak ugotavlja, kako ljudje to stvarnost razumejo in kakšen pomen ji pripisujejo (Tratnik 2002, 26). Slednje lahko raziskovalec doseže skozi kvalitativno raziskovanje, za katerega so značilni besedni opisi ali pripovedi, pri čemer je tudi gradivo obdelano na beseden način. Tudi Flere $(2000,34)$ kvalitativno metodologijo opisuje kot interpretativni postopek, pri katerem raziskovalec ne izhaja iz podmene, da so vloge in dogodki fiksirani, temveč, da se vedenje akterjev nenehno spreminja. Za kvalitativno raziskavo je značilno, da je raziskovalec primarni instrument zbiranja podatkov. Svoje delo mora opraviti na terenu, pri tem pa uporablja induktivno raziskovalno strategijo (Merriam 1998, 7). Raziskovalec mora razčistiti svoja izhodišča oz. svoj pogled na svet in teoretična izhodišča izven raziskave, da se $\mathrm{v}$ čim večji meri izogne pristranskosti (t. i. biasu). Kvalitativno raziskovanje nam omogoča boljše razumevanje vsakodnevnega življenja (Alvesson in Deetz 2000, 50), z njim raziskovalec pridobi globlje razumevanje oz. uvid v bistvo stvari, dogodkov in procesov (Merriam 1998, 7). Pri kvantitativni raziskavi pa osnovno gradivo sestavljajo podatki, ki so pridobljeni s standardiziranimi merskimi postopki in tudi analizirani z matematičnimi ins statističnimi metodami (Mesec 1998, 26).

Mnogi avtorji v svojih delih razmišljajo o prepletanju kvalitativnih in kvantitativnih metod (Easterby-Smith, Thorpe in Lowe 2005; Sagadin 2001; Sagadin 2004; Silverman 2005; Tratnik 2002). Sagadin (2001, I4) predlaga prilagajanje raziskovalnih metod problemom, ki jih raziskujemo. Rezultati obeh pristopov naj se med seboj dopolnjujejo v smiselno celoto (Sagadin 2004, 90). Tudi Tratnik (2002, 40) pravi, da s kombiniranjem metod pridobivamo različne vrste podatkov, ki se dopolnjujejo med seboj. Kombiniranje je smiselno, če z njim podpiramo namen raziskave. Slednje zagovarjajo tudi Easterby, Thorpe in Lowe (2005, 60), ker po njihovem mnenju s tem pridobimo več pogledov na preučevane pojave.

Odločitev za kombiniran kvalitativno-kvantitativni pristop je posledica mnogih razlogov - navajamo jih spodaj.

- Vodenje je po svoji naravi procesna aktivnost. Po mnenju mnogih avtorjev (Merrriam 1998, 33; Flere 2000, 21; Toš in Hafner-Fink 1998, 23; Alvesson in Deetz 2000, 60) so za raziskovanje procesov kvalitativne metode primernejše, ker z njimi lažje pridemo do poglobljenega razumevanja vsakodnevnih praks. Kvan- 
titativne metode so za raziskovanje procesov bistveno manj uspešne.

- S kvalitativno raziskavo se lotevamo tem oz. vprašanj, ki jih s kvantitativnim raziskovanjem ne bi mogli preučiti, ker o njih premalo vemo, da bi lahko raziskovalni problem primerno konceptualizirali in strukturirali, kar je skladno s Sagadinovim razmišljanjem (200I, I4). Tovrstnih raziskav, ki bi nam služile za izhodiščne, namreč nismo nikjer zasledili.

- Kvantitativna raziskava pa nam omogoča večje posploševanje oz. zunanjo veljavnost (Tratnik 2002, 46).

- V managementu je do določene mere priporočljivo uporabljati mešane metode znotraj iste paradigme, občasno pa celo premik med paradigmami, ker nam omogočajo več pogledov na raziskovalni problem (Easterby, Thorpe in Lowe 2005, 60).

Pri kvalitativnem raziskovanju težko govorimo o veljavnosti merskega instrumenta. Veljavnost pomeni, da nam merski instrument prinaša podatke, ki smo jih želeli dobiti. Pri kvalitativnem raziskovanju veljavnost označujemo s pojmom kredibilnosti (Tratnik 2002, 43). Veljavnost kvalitativne raziskave smo povečali z naslednjimi pristopi:

- triangulacijo: trije viri podatkov znotraj bolnišnic (direktorji, vodje, zaposleni),

- kombinacijo metod zbiranja podatkov (polstrukturirani intervjuji, fokusne skupine, analiza dokumentov),

- verodostojnim prepisom intervjujev.

Vodenje sprememb v bolnišnicah je precej neraziskano področje, zato je bilo smiselno najprej izvesti kvalitativno raziskavo. Mnogi avtorji (Bassey 1999, 24; Silverman 2005, 128; Stake 1995, 35; Yin 1994, 14) poudarjajo pomen eksploratorne študije primera, ki omogoča vpogled v pojav, ki ga ne poznamo dovolj.

\section{Konceptualni okvir raziskave}

Pripravili smo načrt raziskave, na podlagi katerega smo najprej preučili teoretična izhodišča ter opravili izbiro pomembnih in merljivih stilov vodenja. Načrt raziskave je vključeval naslednje korake:

I. preučitev temeljnih pojmov (management, stili vodenja, procesi spreminjanja, vrste sprememb v organizacijah, modeli managementa sprememb idr.); 
2. analiza in sinteza teorij na področju vodenja, modelov managementa sprememb ter povezanosti pristopov $\mathrm{k}$ vodenju $\mathrm{z}$ različnimi vrstami organizacijskih sprememb;

3. oblikovanje konceptualnega teoretičnega (raziskovalnega) modela in priprava kvalitativnega dela empirične raziskave (izhodiščna vprašanja za polstrukturirane intervjuje in terminski načrt raziskave);

4. analiza kvalitativnih podatkov in priprava anketnega vprašalnika;

5. izvedba kvantitativnega dela raziskave;

6. analiza in interpretacija rezultatov kvantitativnega dela raziskave ter izdelava zaključnega dela.

$S$ kvalitativno raziskavo smo želeli ugotoviti razumevanje nekaterih pojmov, ki so bili pomembni pri oblikovanju anketnega vprašalnika. Ti pojmi so se nanašali na razumevanje:

- temeljnih dejavnosti v bolnišnicah,

- perifernih dejavnosti v bolnišnicah,

- radikalnih sprememb temeljnih dejavnosti,

- radikalnih sprememb perifernih dejavnosti,

- inkrementalnih sprememb temeljnih dejavnosti in

- inkrementalnih sprememb perifernih dejavnosti.

Želeli smo ugotoviti, katere spremembe, ki so jih v preučevanih bolnišnicah izvajali v zadnjih treh letih, zaposleni opredeljujejo kot radikalno temeljne, radikalno periferne, inkrementalno temeljne in inkrementalno periferne spremembe. Predvsem pa nas je zanimal proces spreminjanja v okviru posamezne vrste spremembe. Osredotočili smo se na morebitna tveganja pri uvajanju sprememb, motnje v delovnih procesih v času izvajanja sprememb ter odpore in pristope $\mathrm{k}$ vodenju. Želeli smo pridobiti tudi mnenja o najpomembnejših elementih vodenja v procesih spreminjanja in njihovem morebitnem razlikovanju glede na vrsto spremembe.

Temeljna vprašanja za potek intervjujev so bila:

I. Kako razumete pojem temeljne dejavnosti v bolnišnici in katere so po vašem mnenju tovrstne dejavnosti?

2. Kako razumete pojem periferne dejavnosti $\mathrm{v}$ bolnišnici in katere so po vašem mnenju tovrstne dejavnosti?

3. Kako razumete radikalne oz. revolucionarne spremembe temeljnih dejavnosti? 
4. Katere spremembe $\mathrm{v}$ zadnjih treh letih bi opredelili kot radikalno temeljne spremembe (radikalne spremembe temeljnih dejavnosti)?

5. Lahko opišete potek ene izmed RT-sprememb? Zakaj ste izbrali prav to RT-spremembo?

- Lahko opišete proces spreminjanja?

- Kakšno tveganje so/je predstavljale/-a?

- Kolikšne motnje v delovnih procesih je predstavljalo izvajanje te/-h sprememb/-e predstavljalo?

- Kako ste vodili sodelavce v času izvajanja sprememb/-e? - Vprašanje samo za direktorje.

- Lahko opišete stil vodenja vašega neposredno nadrejenega?

- Kaj vam je predstavljalo najtežji del pri uvajanju oz. izvajanju spremembe?

- Ali so se pojavljali odpori pri zaposlenih in kako ste se soočali z njimi?

6. Kako razumete radikalne spremembe perifernih dejavnosti?

7. Katere spremembe $\mathrm{v}$ zadnjih treh letih bi opredelili kot radikalno periferne spremembe?

8. Lahko opišete potek ene izmed $R P$-sprememb? Zakaj ste izbrali prav to RP-spremembo? (Ponovijo se podvprašanja iz vprašanja 5.)

9. Kako razumete inkrementalne spremembe temeljnih dejavnosti?

ı. Katere spremembe v zadnjih treh letih bi opredelili kot inkrementalno temeljne spremembe?

II. Lahko opišete potek ene izmed IT-sprememb? Zakaj ste izbrali prav to IT-spremembo? (Ponovijo se podvprašanja iz vprašanja 5.)

I2. Kako razumete inkrementalne spremembe perifernih dejavnosti?

13. Katere spremembe v zadnjih treh letih bi opredelili kot inkrementalno periferne spremembe?

I4. Lahko opišete potek ene izmed IP-sprememb? Zakaj ste izbrali prav to IP-spremembo? (Ponovijo se podvprašanja iz vprašanja 5.)

15. Kateri so po vašem mnenju najpomembnejši elementi vodenja $\mathrm{v}$ procesih spreminjanja? Se kaj razlikujejo glede na vrsto spremembe - RT-, RP-, IT-, IP-spremembo?

Izhodiščna vprašanja smo med intervjuji dopolnjevali z dodatnimi in pri tem pazili na osredotočenost na procese spreminjanja, morebitna tve- 
ganja in motnje, načine vodenja, največje ovire pri uvajanju sprememb ter odpore. Ugotovitve v zvezi z razumevanjem temeljnih ter perifernih dejavnosti, vrstami sprememb in percepcijo uspešnosti uvedenih sprememb so nam predstavljale osnovo za oblikovanje anketnega vprašalnika.

Pri kvalitativnem raziskovanju mora raziskovalec upoštevati nekatere etične vidike. Soglasje za izvedbo raziskave smo dobili od direktorjev bolnišnic. Najprej smo jih povabili ustno, potem pa smo jim poslali še pisno povabilo, kjer smo jih seznanili z namenom in s cilji raziskave, $\mathrm{z}$ načini zbiranja podatkov ter zagotovitvijo anonimnosti. Po zaključku raziskave smo jim ponudili tudi osebno predstavitev rezultatov. V predstavitvi rezultatov raziskave niso omenjena imena bolnišnic, prav tako ne sodelujočih oseb v raziskavi. Dogovori v zvezi z raziskavo so potekali v novembru 2015. Vse naključno izbrane bolnišnice so pristale na sodelovanje. Težji del je predstavljala uskladitev terminov za izvedbo intervjujev. V decembru 2015 so bili opravljeni intervjuji v šestih bolnišnicah, v januarju 2016 pa še v dveh bolnišnicah ter $\mathrm{z}$ direktorjem Zavoda za zdravstveno zavarovanje Slovenije. Zavod za zdravstveno zavarovanje smo vključili v raziskavo zaradi njegove pomembne vloge pri sprožanju sprememb v zdravstvenih organizacijah. Naredili smo načrt raziskave, po katerem so intervjuji znotraj ene bolnišnice potekali v enem dnevu.

\section{Operacionalizacija konstruktov}

Oče transformacijsko-transakcijskega modela vodenja, Burns, je vodje opredelil bodisi kot transakcijske bodisi kot transformacijske, kar je predstavljalo nadaljevanje dihotomije stilov na področju teorij vodenja. Bass, ki je njegovo delo nadaljeval, pa obeh pristopov ni izključeval. Trdil je, da lahko transformacijski vodja uporablja tudi transakcijski stil vodenja. Vodenje je videl kot kontinuum, kjer je na eni strani transakcijski pristop ( $\mathrm{v}$ katerega je umestil tudi vodenje laissez-faire), na drugi strani pa transformacijsko vodenje (Washington, Sutton in Sauser 2014, I2).

\section{Stili vodenja}

Stile vodenja smo konceptualizirali skladno z Bassovo in Avolijevo (Walumbwa in Zhu 2004, 4-6) opredelitvijo transformacijskega, transakcijskega in vodenja laissez-faire. Njuna lestvica (imenovana Multifactor Leadership Questionnaire) meri širok razpon učinkovitih in neučinkovitih vodstvenih vedenj (Xirasagar, Samuels in Stoskopf 2005, 723). Na neučinkovitem delu MLQ ocenjuje percepcijo vodstvenih vedenj, ki predstavljajo izogibanje odgovornosti in akciji (vodenje brez vajeti oz. vodenje 
laissez-faire), najučinkovitejši del razpona vedenj pa predstavlja transformacijsko vodenje. Merjeno je pet dejavnikov oz. dimenzij transformacijskega vodenja. To so: vpliv - pripisan (angl. attributed), vpliv - vedenje (angl. behaviour), intelektualna spodbuda, individualna obravnava in navdihujoča motivacija. Vprašalnik meri tri dejavnike transakcijskega vodenja, ki so: pogojevano nagrajevanje, management z izjemami (aktivni) in management $\mathrm{z}$ izjemami (pasivni). Zadnji dejavnik je vodenje laissez-faire. Vsak dejavnik je merjen s štirimi trditvami oz. postavkami. Anketirance smo prosili, da odgovorijo, kako pogosto je posamezna trditev veljala za vodjo projekta sprememb oz. osebo, ki je vodila izvajanje najznačilnejše spremembe. Ocenjevali so z uporabo 5 -stopenjske lestvice (o - nikoli, I - redko, 2 - občasno, 3 - pogosto, 4 - zelo pogosto, če ne vedno). Vprašalnik je ponudil tudi opcijo, da so vodje sprememb lahko ocenili sami sebe.

\section{Vrste sprememb}

Lestvico za merjenje vrste sprememb smo konceptualizirali skladno $\mathrm{s}$ Penningtonovo tipizacijo $(2003,6)$, pri čemer smo osnovne značilnosti radikalnih in inkrementalnih sprememb povzeli po nekaterih avtorjih (Burke 2002; Hussey 1995). Predhodna kvalitativna raziskava pa nam je omogočila razmejitev temeljnih in perifernih oz. podpornih dejavnosti $\mathrm{v}$ bolnišnicah ter radikalnih in inkrementalnih sprememb $\mathrm{v}$ teh dejavnostih. Postavili smo lastno mersko lestvico, sestavljeno iz dvajsetih postavk. Vsaka vrsta spremembe je merjena s petimi trditvami oz. postavkami. Anketirance smo prosili, da ocenijo, do katere mere se strinjajo glede značilnosti spremembe, ki so jo izvajali v zadnjem letu, in je vplivala na delo njihovega oddelka oz. organizacijske enote. Respondenti so dajali ocene na 5 -stopenjski lestvici ( 1 - sploh se ne strinjam, 2 - se ne strinjam, 3 - niti se ne strinjam niti se strinjam, 4 - se strinjam, 5 - popolnoma se strinjam). Ker so v posameznih bolnišnicah različno opredeljevali pojma temeljnih in podpornih dejavnosti, ima lestvica tudi pojasnilo, katere dejavnosti uvrščamo med temeljne in katere med podporne. Uvrstitev dejavnosti med temeljne oz. podporne smo opravili sami, delno na podlagi kvalitativne analize, delno pa na podlagi smiselne delitve procesov v bolnišnicah.

\section{Uspešnost uvedene spremembe}

Uspešnost uvedene spremembe je konceptualizirana kot percepcija oz. zaznava doseganja začrtanih ciljev, namena spremembe, začrtanih rokov 
in okvira načrtovanih stroškov. Lestvica sestoji iz štirih postavk. Anketiranci so dajali ocene na 5 -stopenjski lestvici ( 1 - sploh se ne strinjam, 2 se ne strinjam, 3 - niti se ne strinjam niti se strinjam, $4-$ se strinjam, 5 popolnoma se strinjam).

\section{Priprava vprašalnika}

Po zaključenih intervjujih smo opravili njihovo delno analizo in na njeni podlagi pripravili anketni vprašalnik v delu, ki se je nanašal na spremembe. Del vprašalnika, ki se je nanašal na stile vodenja (Multifactor Leadership Questionnaire MLQ - $5 \mathrm{X}$ ), smo decembra 2015 naročili pri ameriškem podjetju Mind Garden. Podjetje je poslalo tudi slovensko različico vprašalnika, ki pa smo jo zaradi boljšega razumevanja morali nekoliko prilagoditi. Vprašalnik je avtorska last podjetja Mind Garden, ki ne dovoljuje njegovega celotnega razkritja, zato ga v monografiji v celoti nikjer ne razkrijemo.

Merske lestvice smo postavili na osnovi opredelitev konstruktov. Oblikovane so za specifičen kontekst (okolje bolnišnic) in v drugih kontekstih niso uporabne. Posebno pozornost smo namenili tipu vprašanj, ki so bila v celoti zaprtega tipa. Ob pripravi vprašalnika smo že vnaprej načrtovali obdelavo podatkov. Pazili smo, da merske spremenljivke ne vključujejo stvari, ki niso del konceptualizacije. Pozornost smo namenili tudi primernemu besednemu oblikovanju merskih spremenljivk in s tem zagotovili, da se niso pojavljale dvoumnosti ali vprašanja z več razsežnostmi.

Pilotno preverjanje vprašalnika je potekalo februarja $2016 \mathrm{v}$ eni izmed preučevanih bolnišnic in je trajalo dva tedna. Vprašalnik je bil poslan petindvajsetim zaposlenim. Preverjali smo njegovo ustreznost oz. razumljivost ter čas, potreben za izpolnitev vprašalnika. Vrnjenih smo dobili 20 izpolnjenih vprašalnikov. Anketiranci niso izpostavili težav glede razumljivosti vprašalnika. Pri vrnjenih vprašalnikih smo kljub temu opazili, da štirje nimajo odgovora pri prvi trditvi, ki se nanaša na značilnosti spremembe, zato smo to trditev malenkostno spremenili (skrajšali). Ker z izpolnjevanjem anketiranci niso imeli težav, smo sklepali, da je vprašalnik ustrezen in razumljiv. Anketni vprašalnik smo v papirnati verziji distribuirali po bolnišnicah konec februarja 2016. Po treh tednih smo z anketiranjem zaključili. Ker v bolnišnicah velik delež zaposlenih (ponekod več kot 40 odstotkov) nima elektronskih naslovov, nismo mogli izvajati spletnega anketiranja. 


\section{Opis vzorca}

Uporabili smo dvostopenjsko vzorčenje. Okvir vzorčenja v prvi stopnji je bil seznam vseh bolnišnic, ki smo ga označili z zaporednimi številkami od I do 26. Z računalniškim programom smo generirali 8 naključnih številk, ki so pomenile zaporedno mesto bolnišnic (enostavno slučajno vzorčenje). V raziskavi je sodelovalo teh osem naključno izbranih bolnišnic, kar predstavlja skoraj tretjino vseh slovenskih bolnišnic. Število zaposlenih v preučevanih bolnišnicah med raziskavo je bilo približno 5.600, število vseh zaposlenih v slovenskih bolnišnicah pa približno 23.000. Izmed bolnišnic sta bili dve terciarni ustanovi, ena specialna bolnišnica ter pet splošnih bolnišnic. Bolnišnice se po »Pravilniku o merilih za razvrščanje

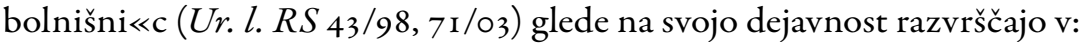

- $\quad$ specialistične bolnišnice, ki morajo izvajati poglobljeno diagnostiko, zdravljenje in medicinsko rehabilitacijo, zdravstveno nego, nastanitev in prehrano; svojo dejavnost opravljajo za bolnike iz več regij oz. za bolnike iz celotne države;

- $\quad$ splošne bolnišnice, ki praviloma opravljajo svojo dejavnost za bolnike iz določene regije; splošne bolnišnice morajo razvijati in izvajati dejavnosti vseh medicinskih strok, ki jih prebivalci določene regije potrebujejo, minimalno število dejavnosti pa mora obsegati najmanj splošno internistično, kirurško in pediatrično ali ginekološko dejavnost;

- terciarne ustanove, ki opravljajo terciarno zdravstveno dejavnost za področje celotne države.

Kvalitativne podatke smo zbirali med zaposlenimi treh hierarhičnih nivojev. Pri tem smo uporabili namenski vzorec, ki je temeljil na predpostavki, da naj bo izbrani vzorec takšen, da se iz njega lahko največ nauči (Merriam I998, 6I). Prvi nivo so predstavljali direktorji in pomočniki direktorjev (osebe $\mathrm{z}$ mandatom), drugi nivo so predstavljali vodje in tretji nivo zaposleni brez vodstvenih funkcij. V kvalitativni raziskavi je sodelovalo i 3 I oseb, od tega iz prvega nivoja 8 poslovnih direktorjev, 2 strokovna direktorja in ro pomočnikov direktorjev za področje zdravstvene nege. Iz drugega nivoja je sodelovalo 58 vodij, ki so jih izbrali direktorji glede na njihovo časovno razpoložljivost. Bili so predstavniki različnih področij: predstojniki bolniških oddelkov; vodje tehničnih služb, finančno-računovodskih oddelkov, raziskovalnih oddelkov, fizioterapije, laboratorijev, kuhinje, oddelkov za kakovost idr. Sodelovalo je tudi 53 zaposlenih (brez vodstvenih vlog), ki so jih izbrali vodje. Izbrali so tiste, ki so o 
tematiki največ vedeli in so v času intervjujev lahko sodelovali oz. si vzeli čas. So pa bili med njimi predstavniki različnih služb, oddelkov ali enot.

$\mathrm{V}$ kvantitativnem delu raziskave smo bolnišnicam poslali $3.000 \mathrm{iz}-$ vodov anketnih vprašalnikov, kar predstavlja $54 \%$ vseh zaposlenih v teh bolnišnicah. Vsaka bolnišnica je dobila proporcionalno število izvodov glede na število zaposlenih. $Z$ direktorji oz. $\mathrm{v}$ večjih bolnišnicah tudi kadrovskimi direktorji smo se dogovorili, da vprašalnike razdelijo glede na načelo proporcionalnosti po vseh organizacijskih enotah in pri tem poleg števila zaposlenih $\mathrm{v}$ posamezni organizacijski enoti upoštevajo tudi poklicne profile, starost in spol. Nekatere vrste sprememb so bile vezane na posamezne organizacijske enote in določene poklicne profile, zato je bilo smiselno organizacijske enote uporabiti kot delne okvire vzorčenja v drugi stopnji. Uporabili smo kvotni vzorec, pri katerem smo izbor oseb glede na postavljene kriterije prepustili bolnišnicam. Sezname so pripravili v kadrovskih službah. $Z$ razdelitvijo populacije na stratume, ki so pomembni z vidika raziskave, smo želeli doseči zastopanost zaposlenih vseh poklicnih profilov, starosti in spolov tudi znotraj organizacijskih enot posamezne bolnišnice. Iz tako oblikovanih subpopulacij je bil v vzorec izbran vsak drugi zaposleni (način sistematičnega vzorčenja), med neizbranimi pa je bil do izpolnitve kvot ponovljen izbor vsakega drugega zaposlenega. $S$ slučajno izbiro na nivoju posamezne bolnišnice bi lahko dobili vzorec, kjer ne bi bile enakomerno zastopane vse poklicne skupine znotraj vseh organizacijskih enot. $\mathrm{Na}$ ta način smo dosegli dobro reprezentativnost vzorca. $V$ večjih bolnišnicah so si pri izdelavi seznamov pomagali s kadrovskim informacijskim sistemom. Zaradi časovne stiske smo z omenjenim kvotnim vzorčenjem tudi želeli pospešiti proces zbiranja podatkov.

\section{Metode zbiranja podatkov}

Kot smo že pojasnili v prejšnjih poglavjih, smo se v okviru kvalitativnega dela raziskave odločili za uporabo polstrukturiranega intervjuja z namenom, da bi dobili poglobljen vpogled v procese spreminjanja. Intervjuji so lahko različno strukturirani, od odprtega pogovora do zelo strukturiranih vprašanj zaprtega tipa (Easterby-Smith, Thorpe in Lowe 2005, II 4). $\mathrm{V}$ pretežnem delu smo izvajali skupinske intervjuje na način fokusnih skupin. Držali smo se načrta raziskave, ki je predvideval izvedbo intervjujev v posamezni bolnišnici ob točno določenih urah: ob 9. uri z direktorji, ob i I. uri z vodji ter ob i3. uri z zaposlenimi. Intervju z vsako skupino je $\mathrm{v}$ povprečju trajal več kot uro. Skupine direktorjev in njihovih pomočnikov so imele največ pet udeležencev, $v$ dveh bolnišnicah pa sta sodelovala 
samo direktorja. Velikost vseh ostalih skupin se je gibala med 7 in 13 udeleženci. Udeležence smo na začetku seznanili z namenom in cilji raziskave ter anonimnostjo bolnišnic in sodelujočih intervjuvancev. Prosili smo jih, da bi intervjuje lahko snemali, na kar so vsi pristali. Zaradi zagotavljanja anonimnosti v raziskavi ne razkrivamo imen posameznikov, prav tako ne sodelujočih bolnišnic.

Fokusne skupine so oblika skupinskega intervjuja, pri katerem pridobimo podatke iz pogovora med udeleženci. Na vprašanja ni odgovarjal vsak posameznik, temveč smo izkoristili skupinsko interakcijo in spodbujali pogovor med udeleženci. Metoda se uporablja za raziskovanje tega, kaj ljudje razmišljajo, predvsem pa tudi, kako razmišljajo. Izbrano metodo smo ocenili kot najprimernejšo, saj smo želeli pridobiti razumevanje pojmov, povezanih z vrstami sprememb v bolnišnicah, želeli pa smo tudi dobiti vpogled $\mathrm{v}$ procese spreminjanja, stile vodenja in njihovo razumevanje ter konkretne spremembe, ki so jih izvajali. S fokusnimi skupinami smo pridobili osnovne informacije o raziskovani temi. Šlo je za obliko eksplorativne raziskave, $s$ katero smo ugotovili, za kakšna mnenja gre, da smo kasneje lahko nadaljevali $\mathrm{z}$ anketo. Eksplorativne raziskave razodevajo vsebino problema, ne dajo pa dokončnih rešitev, obrazložitev ali pojasnitev (Flere 2000, 54). V intervjujih nas je zanimalo predvsem razumevanje radikalno temeljnih, radikalno perifernih, inkrementalno temeljnih in inkrementalno perifernih sprememb. Zanimalo nas je tudi, katere spremembe so izvajali $\mathrm{v}$ zadnjih letih in kako so se lotevali njihovega izvajanja. Želeli smo dobiti odgovore na vprašanja, kako so se soočali z morebitnimi odpori in motnjami ter kakšni načini vodenja so prevladovali. Z vsakim intervjujem smo pridobivali natančnejši in poglobljen vpogled $\mathrm{v}$ tematiko, ki nam je močno pomagal pri oblikovanju anketnega vprašalnika za drugi del raziskave.

V kvantitativnem delu smo uporabili vprašalnik, ki je vseboval kratka navodila. Sestavo vprašalnika smo opisali v enem izmed prejšnjih poglavij, prav tako tudi izvedbo pilotnega testiranja. Želeli smo postaviti vprašalnik v spletni obliki. Ker pa velik del zaposlenih v bolnišnicah nima dostopa do elektronske pošte, smo to namero opustili, kljub zavedanju, da je na ta način hitrost zbiranja podatkov manjša in lahko pride do administrativnih napak pri vnosu $\mathrm{v}$ statistični program.

\section{Metode analiziranja podatkov}

Analizo kvalitativnih podatkov smo opravili skladno s splošnim analitičnim postopkom, ki ga predlagata Miles in Huberman (1994, 172-205). Analizo predstavljamo v obliki skupnega prikaza vseh preučevanih bol- 
nišnic, posameznih primerov oz. bolnišnic ne obravnavamo. Med seboj jih primerjamo le v tistih segmentih, ki so se zelo razlikovali. Zbrani podatki so obsegali več kot 200 strani transkripcij. Gradivo smo organizirali $\mathrm{v}$ zaključene vsebinske sklope, $\mathrm{v}$ katere smo smiselno združevali odgovore. Vprašanja $\mathrm{v}$ intervjujih so bila do neke mere že strukturirana $\mathrm{v}$ kategorije, ki smo jih ohranili tudi pri analizi podatkov. Po večkratnem prebiranju zapisov smo oblikovali kategorije, ki jih predstavljamo spodaj.

I. Opredelitev temeljnih in perifernih dejavnosti v bolnišnicah. V to kategorijo smo uvrstili analizo in interpretacijo odgovorov na vprašanji $\mathrm{I}$ in 2.

2. Področja in vrste radikalnih sprememb. $\mathrm{V}$ to kategorijo smo uvrstili analizo in interpretacijo odgovorov na vprašanja 3, 4, 6 in 7 .

3. Področja in vrste inkrementalnih sprememb. $\mathrm{V}$ to kategorijo smo uvrstili analizo in interpretacijo odgovorov na vprašanja 9, $\mathrm{IO}, \mathrm{I} 2$ in 13.

4. Značilnosti procesov spreminjanja. V to kategorijo smo uvrstili analizo in interpretacijo odgovorov na vprašanja $5 \mathrm{a}, 5 \mathrm{~b}, 5 \mathrm{c}, 5 \mathrm{f}, 5 \mathrm{~g}$ ter ista podvprašanja pri vprašanjih $8, \mathrm{I}$ I in $\mathrm{I} 4$.

5. Pristopi k vodenju sprememb. V to kategorijo smo uvrstili analizo in interpretacijo odgovorov na vprašanja $5 \mathrm{~d}$, se ter ista podvprašanja pri vprašanjih 8 , I I in $\mathrm{I} 4$.

6. Ključni elementi vodenja $\mathrm{v}$ procesih spreminjanja. $\mathrm{V}$ to kategorijo smo uvrstili analizo in interpretacijo odgovorov na vprašanje I5.

V kvantitativnem delu raziskave smo značilnosti merjenih spremenljivk analizirali z metodami univariatne (Pearsonov koeficient, test Kolmogorov-Smirnov za preverjanje porazdelitve normalnosti), bivariatne (korelacija, t-test za preverjanje porazdelitve normalnosti) in multivariatne statistične analize (faktorska analiza, večkratna regresija). Indikatorje posameznih konstruktov predstavljamo z opisno statistiko, tj. povprečjem odgovorov pri vsakem indikatorju, $s$ standardnim odklonom ter koeficientom asimetričnosti in sploščenosti. Pred začetkom analize smo manjkajoče vrednosti $\mathrm{v}$ delu odgovorov, ki se nanašajo na ocene stilov vodenja, nadomestili z EM-algoritmom (Expectation - Maximization). Manjkajočih podatkov pri ocenah za vrste sprememb nismo nadomeščali, ker smo predvidevali, da nekaterih sprememb v bolnišnicah niso izvajali. 
Preden smo začeli s kakršno koli analizo, smo želeli preveriti objektivnost merskega instrumenta, kar smo naredili s faktorsko analizo. Prav tako smo morali preveriti veljavnost in zanesljivost merskega instrumenta. Zanesljivost merjenja se kaže $\mathrm{v}$ tem, da pri ponovljenem merjenju pridemo do enakih rezultatov (Tratnik 2002, 45). Gre torej za konsistentnost meritev, tj. podobnost rezultatov, ki jih dobimo s ponavljanjem merjenja v enakih okoliščinah. Veljavnost pa se nanaša na to, v kolikšni meri smo prepričani, da instrument resnično meri atribut, ki ga želimo meriti (Easterby-Smith, Thorpe in Lowe 2005, I68), kar je običajno zelo težko ugotoviti, kajti novega instrumenta ne bi potrebovali, če bi imeli boljši način merjenja določenega atributa. Oprli smo se na zdravorazumsko veljavnost, ki temelji na ideji, da je merjenje določenega atributa veljavno, če se rezultati ujemajo z obstoječim znanjem, kar omenjeni avtorji (prav tam) imenujejo kot »zmožnost testa, da nam pove, kar že vemo «.

$S$ faktorsko analizo smo želeli identificirati faktorje, ki merijo posamezne konstrukte. Izvedli smo jo v delu vprašalnika, ki se je navezoval na spremembe. Nato smo izračunali vrednosti posameznih konstruktov in na osnovi teh izvedli analizo. Uporabili smo tudi multiplo regresijsko analizo. Namen tovrstne linearne regresije je ugotoviti velikost in smer odnosov med eno odvisno in več neodvisnimi spremenljivkami ter napovedati vrednost odvisne glede na vrednost neodvisnih spremenljivk.

V analizo so bile vključene še naslednje neodvisne spremenljivke:

- spol anketiranca z zalogo vrednosti: moški, ženska;

- vloga anketiranca z zalogo vrednosti: direktor, vodja projekta, sodelavec, drugo;

- kategorija uspešnosti z zalogo vrednosti: uspešni, neuspešni.

Neodvisne spremenljivke, ki so predstavljene samo v opisni statistiki:

- starost anketiranca z zalogo vrednosti: manj kot 30 let, $31-40$ let, 4I-50 let, 5I-60 let in več kot 60 let;

- vrsta bolnišnice z zalogo vrednosti: splošna bolnišnica, specialna bolnišnica, terciarna bolnišnica;

- spol ocenjevanje osebe z zalogo vrednosti: moški, ženska;

- starost ocenjevane osebe z zalogo vrednosti: manj kot 30 let, 3 I40 let, $4 \mathrm{I}-50$ let, $5 \mathrm{I}-60$ let in več kot 60 let;

- vključenost $\mathrm{v}$ izvajanje sprememb z zalogo vrednosti: aktivna, pasivna.

$S$ korelacijsko analizo predstavljamo odnose med merjenimi spremenljivkami. 



\section{Empirična raziskava}

$\mathrm{V}$ empiričnem delu monografije bomo najprej predstavili rezultate kvalitativnega dela raziskave, $\mathrm{v}$ nadaljevanju pa še analizo in interpretacijo kvantitativnega dela raziskave. Analiza kvalitativnih podatkov je drugačna od numerične oz. od analize podatkov, ki smo jih zbrali z anketnim vprašalnikom. Podatki so analizirani in razvrščeni v kategorije, ki jih predstavljajo naslovi posameznih podpoglavij.

\section{Analiza, rezultati in ugotovitve kvalitativne raziskave}

Zaradi anonimnosti vključenih bolnišnic $\mathrm{v}$ raziskavo smo le-te označili z velikimi črkami: A, B, C, D, E, F, G in $\mathrm{H}$. Nivoje zaposlenih pa smo označili še s številkami: $A_{1}, A_{2}$ in $A_{3}$. Oznaka $A_{1}$ pomeni skupino direktorjev in pomočnikov direktorjev v bolnišnici $\mathrm{A}, \mathrm{A} 2$ pomeni skupino vodij v bolnišnici $\mathrm{A}, \mathrm{A}_{3}$ pa pomeni skupino zaposlenih v bolnišnici $\mathrm{A}$. Enak sistem označevanja smo postavili za ostale bolnišnice. Naša analiza ne prikazuje vsakega posameznega primera oz. bolnišnice posebej, temveč gradi splošno razlago, ki se prilega vsem posameznim primerom. Tovrstno analizo Yin (1994, I I2) imenuje prečna analiza (angl. cross-case analysis).

\section{Opredelitev temeljnih in perifernih dejavnostiv bolnišnicah}

»Zakon o zdravstveni dejavnosti« (Ur. l. RS, št. 23/os) slovensko zdravstvo deli na primarno, sekundarno in terciarno raven. Primarna raven obsega osnovno zdravstveno dejavnost (zdravstveni domovi) in lekarniško dejavnost. Sekundarna raven obsega bolnišnično zdravljenje in dejavnost specialističnih ambulant, kamor poleg zdravljenja uvrščamo tudi di- 
agnostiko. Sekundarna raven podpira primarno. Terciarna dejavnost pa je vezana na klinike, klinične oddelke in inštitute, ki poleg najzahtevnejšega zdravljenja izvajajo zdravstveno-raziskovalno in pedagoško delo za Medicinsko fakulteto ter druge fakultete in visoke ter višje šole. Klinike, klinični oddelki in inštituti oblikujejo doktrino zdravljenja na svojem področju ter jo posredujejo drugim bolnišnicam oz. zdravstvenim delavcem.

\section{Razurstitev preučevanih bolnišnic glede na dejavnost}

Med našimi preučevanimi bolnišnicami sta bili dve terciarni ustanovi, pet splošnih bolnišnic in ena specialna. Splošne bolnišnice in specialna bolnišnica opravljajo dejavnost na sekundarni ravni. Splošne bolnišnice zdravijo več vrst bolezni, opravljajo specialistično ambulantno dejavnost in imajo posteljne zmogljivosti za najmanj štiri medicinske stroke: interno medicino, kirurgijo, pediatrijo in ginekologijo ali porodniške dejavnosti. Specialna bolnišnica pa opravlja specialistično ambulantno in bolnišnično zdravljenje določene bolezni oz. določene skupine prebivalcev. Izpolnjevati mora vse pogoje za bolnišnico, le da ima posteljne, diagnostične in druge zmogljivosti prilagojene svojemu namenu.

\section{Razumevanje pojmov temeljne in periferne dejaunosti}

V preučevanih bolnišnicah smo želeli priti do odgovora, kako opredeljujejo svoje temeljne ter periferne dejavnosti. Odgovore na prvo in drugo vprašanje smo združili v kategorijo »temeljne in periferne dejavnosti $\mathrm{v}$ bolnišnicah «. Na začetku moramo izpostaviti, da so v treh bolnišnicah poudarili, da se jim zdi izraz periferne dejavnosti nekoliko neprimeren, ker bi te dejavnosti lahko obravnavali kot manj pomembne, kar pa zagotovo niso. Eden izmed direktorjev v bolnišnici B je dejal, da mu izraz zveni kot nekaj »postranskega, na robu dogajanja«. Tudi direktor Zavoda za zdravstveno zavarovanje je povedal, da v bolnišnici potekajo glavni in podporni procesi, vendar pa se, ko so jih hoteli razmejiti, nihče ni hotel videti kot »podporni «, zato so rekli, da so vsi procesi enako pomembni. Obrazložili smo, da je izraz periferna dejavnost oz. poimenovanje povzeto po določenem avtorju in ga nismo spreminjali. Skupaj z intervjuvanci smo opredelili, da gre za podporne dejavnosti, kar je v zdravstvu oz. bolnišnicah bolj uporabljen izraz za vse pomožne procese. Za namene raziskave pa še vedno uporabljamo izraz periferne dejavnosti, ker iz njega izhaja tudi poimenovanje dveh vrst sprememb. Poleg tega se držimo že opredeljene Penningtonove tipizacije, ki opredeljuje temeljne in periferne 
procese ter radikalne in inkrementalne spremembe omenjenih procesov.

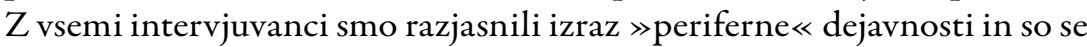
na koncu strinjali z njegovo uporabo.

Intervjuvanci so opisali svoje razumevanje pojmov temeljnih in perifernih oz. podpornih dejavnosti v bolnišnicah, ki jih razumejo podobno, vendar se konkretne dejavnosti, ki jih uvrščajo med ti dve opredelitvi, zelo razlikujejo. Direktorica v bolnišnici A I je npr. povedala:

Temeljne dejavnosti so naše poslanstvo. Izvajamo hospitalno in specialistično ambulantno dejavnost za prebivalstvo svoje regije. Tudi direktorji in njihovi pomočniki B I so izpostavili dejstvo, da:

...bolnišnica obstaja zaradi skrbi za zdravje prebivalstva v regiji.

Intervjuvanci $\mathrm{B}_{1}, \mathrm{C}_{2}, \mathrm{C}_{3}, \mathrm{~F}_{2}, \mathrm{~F}_{3}, \mathrm{G}_{2}$ in $\mathrm{G}_{3}$ prav tako temeljno dejavnost bolnišnice neposredno povezujejo z dejavnostmi zdravljenja oz. oskrbe bolnikov. Pri opredelitvi temeljnih dejavnosti so se direktorji $\mathrm{B}_{\mathrm{I}}$, $\mathrm{D}_{\mathrm{I}}$ in $\mathrm{H}_{\mathrm{I}}$ sklicevali na temeljna predpisa bolnišnic, tj. »Akt o ustanovitvi« ter $\gg$ Statut «. Direktor BI je povedal:

Temeljne dejavnosti so zagotovo tiste, ki so opredeljene že v samem predpisu za delovanje bolnišnice. To so štirje osnovni oddelki: interni, kirurgija, pediatrija in ginekologija. Poleg tega bi moral vseeno reči, da so temeljne tudi laboratorijske dejavnosti in rentgenska diagnostika.

Eden izmed vodij D2 je izpostavil še »Poslovnik o sistemu vodenja《, ki so ga v tej bolnišnici pripravili za namen pridobivanja ISO-standarda, imajo pa v dokumentu zapisane svoje temeljne dejavnosti. Se pa Poslovnik o sistemu vodenja navezuje na dva temeljna akta, tj. »Akt o ustanovitvi $\ll$ in $\gg$ Statut $\ll$. Dejal je:

To delitev smo naredili že v Poslovniku vodenja za potrebe standarda ISO.

Tu notri smo utemeljili in opredelili, da so temeljne: zdravstvena dejavnost na sekundarnem in terciarnem nivoju, znanstveno-raziskovalna in pedagoška dejavnost.

Bolnišnica A je splošna bolnišnica, v kateri izvajajo bolnišnično in specialistično ambulantno dejavnost na sekundarnem nivoju. Je regijska bolnišnica, kar pomeni, da izvajajo različne dejavnosti, ki pokrivajo zdravstveno obravnavo bolnikov v regiji na internističnem ter splošno kirurškem področju, ki se zadnja leta vse bolj specializira v posamezne dejavnosti kirurgije, kot so: ortopedija, travmatologija, abdominalna ki- 
rurgija, žilna kirurgija, plastična kirurgija, urologija. Tudi internistične stroke se vse bolj specializirajo - nefrologija, revmatologija, diabetologija, gastrologija, kardiologija, pulmologija ter ostale dejavnosti (dermatologija, otorinolaringologija, ginekologija). Vse našteto opredeljujejo kot ključne oz. temeljne dejavnosti. Vse pomembnejša postaja paliativna oskrba, kajti potrebe starajočih se prebivalcev in potrebe po obvladovanju njihovih bolezni kažejo na to, da bo negovalna bolnišnica rasla in prehajala na dolgotrajno oskrbo. Ena temeljnih dejavnosti je tudi urgentna dejavnost. Med periferne oz. podporne dejavnosti so v bolnišnici A uvrstili: laboratorije, lekarno, dejavnost psihologov in socialne službe, kurirsko-transportno službo, obvladovanje bolnišničnih okužb, kuhinjo, pralnico, tehnično službo, informatike, nabavo. Pri nekaterih od teh dejavnosti veliko pomagajo tudi prostovoljci.

Bolnišnica B je prav tako splošna bolnišnica, $v$ kateri izvajajo štiri temeljne dejavnosti: kirurško, interno, ginekološko in pediatrično. V zadnjem času med temeljne dejavnosti uvrščajo tudi raziskovalno dejavnost. V tej bolnišnici je skupina direktorjev med temeljne dejavnosti poleg rentgenske diagnostike uvrstila tudi laboratorijske dejavnosti. Med periferne v bolnišnici B uvrščajo: zdravstvene dejavnosti, ki jih lahko ambulantno organizirajo (pogojno), transportno službo, kuhinjo, čiščenje, lekarno in prostovoljske dejavnosti.

Tudi bolnišnica C spada med splošne bolnišnice. Med temeljne dejavnosti štejejo vso bolnišnično dejavnost, ki je organizirana v različnih oddelkih, ter specialistično ambulantno dejavnost. Med podporne dejavnosti pa v bolnišnici $C$ uvrščajo: upravo (mišljeno kot različne upravno-poslovne službe), tehnično-vzdrževalne službe, pralnico, kuhinjo, nabavo, prodajo, informatiko, računovodstvo idr. Kadri so zanje izjemno pomembni.

Bolnišnica D spada med terciarne ustanove. Med temeljne dejavnosti uvrščajo njihovo bolnišnično in ambulantno dejavnost. Zaradi statusa terciarne ustanove sta za njih pomembni tudi raziskovalna in pedagoška dejavnost, kar je direktor opisal takole:

Na terciarnem nivoju smo povezani z Medicinsko fakulteto, imamo kompletno izobraževanje, tudi na lokaciji klinike.

Med periferne dejavnosti uvrščajo vse upravno-poslovne službe, kuhinjo in tehnično službo.

Tudi bolnišnica E spada med terciarne ustanove. Med temeljne dejavnosti uvrščajo rehabilitacijo, prav tako pa tudi raziskovalno in pedago- 
ško dejavnost. Kot podporne pa navajajo čiščenje, informatiko in finančno službo.

Bolnišnica F je specialna bolnišnica, ki med svoje temeljne dejavnosti uvršča bolnišnični akutni oddelek in neakutno bolnišnično obravnavo, kamor sodijo podaljšano bolnišnično zdravljenje, bolnišnična nega in paliativna oskrba. Temeljne dejavnosti so tudi ambulantne dejavnosti: kardiološka, pulmološka (vezana na oddelek), nefrološka, virološka, nevrološka, psihiatrična in urološka. Skupina zaposlenih je svoje dejavnosti opisala takole:

Temeljne dejavnosti so vse, ki se tičejo pacienta. Zdravljenje pacienta. Drugo so potem podporne službe; računovodska služba, recimo ... kuhinja, čistilke, vzdrževanje, nabava, javna naročila, informatika.

Med periferne dejavnosti v tej bolnišnici uvrščajo: diagnostično dejavnost (rentgen, ultrazvok), biokemični laboratorij, bolnišnično lekarno za oskrbo z zdravili in ostalimi medicinskimi pripomočki, kuhinjo, vzdrževanje, sterilizacijo, računovodsko službo, nabavo, javna naročila in informatiko.

Bolnišnica G spada med splošne bolnišnice. Njihove temeljne dejavnosti vključujejo pet področij: interno medicino, kirurgijo, ginekologijo, porodništvo ter pediatrijo. Organizirane so v različnih oddelkih in specialistični ambulantni dejavnosti. Med periferne dejavnosti uvrščajo: tehnično službo, čistilni servis, upravne službe, laboratorije, lekarno in administracijo. Vodje v tej bolnišnici so razmejitev dejavnosti predstavili z naslednjim opisom:

Temeljne dejavnosti se dotikajo obravnave pacientov in so vezane na zdravljenje. Podporne pa nekatere dejansko podpirajo temeljne, nekatere pa so tudi osnovne.

Njihov odgovor kaže na različno razmejevanje dejavnosti, kar je posledica specifičnega obravnavanja različnih strok v zdravstvu. Večina zdravstvenega kadra $\mathrm{v}$ bolnišnicah obravnava zdravstveno in medicinsko stroko kot $\gg$ pravo stroko «, medtem ko druga področja obravnavajo kot podporne službe in jih ne vidijo kot samostojne stroke. Delitev na »strokovne « in »podporne službe « je v bolnišnicah tako močno zasidrana, da je celo direktor bolnišnice $\mathrm{H}$ opisal situacijo takole:

Manko našega izobraževalnega sistema na področju zdravstvu je ta, da tem profilom ne da neke širine ... in vedno se govori, češ ja, stroka bo odločila, kot da npr. pravna ali ekonomska stroka nista stroki. 
Direktor Zavoda za zdravstveno zavarovanje je to izpostavil z naslednjimi besedami:

Zdravniki imamo veliko nakopičenega znanja, vendar na zelo ozkem področju. Problem je visok ego, mnogo zdravnikov je tudi narcisoidno strukturiranih osebnosti, ki favorizirajo svojo stroko.

Periferne dejavnosti se izvajajo v podpornih službah. Vsaka služba deluje skladno s pravili in standardi svoje stroke, četudi funkcionira v podpornih procesih bolnišnice.

Bolnišnica $\mathrm{H}$ je tudi splošna bolnišnica, ki ima temeljne zdravstvene dejavnosti organizirane v pet matičnih oddelkov: pediatrični oz. otroški oddelek; ginekološko-porodni oddelek; oddelek za anesteziologijo, reanimatologijo in intenzivno zdravljenje; kirurški oddelek in interni oddelek. Podporne dejavnosti delijo na zdravstvene in nezdravstvene. Obojim je skupno, da so servis temeljnim dejavnostim. Med podporne zdravstvene dejavnosti uvrščajo fizioterapijo, lekarno, laboratorij, radiološki oddelek in urgentni center, med podporne nezdravstvene pa kuhinjo, pralnico, šivalnico, tehnično službo in upravo.

Bolnišnice so $\mathrm{v}$ pretežni meri podobno opredeljevale pojma temeljnih in podpornih dejavnosti. Analiza pa je pokazala, da je ponekod prišlo tudi do razhajanj. Intervjuvanci BI so laboratorije uvrstili med temeljne dejavnosti. Skupina Fı je med podporne dejavnosti uvrstila diagnostično dejavnost (rentgen in ultrazvok), prav tako $\mathrm{H}_{\mathrm{I}}$, ki je med podporne uvrstila fizioterapijo, rentgenski oz. radiološki oddelek in urgentni center. Dogajalo se je tudi, da so bili intervjuvanci znotraj posameznih bolnišnic različnih mnenj glede razumevanja pojmov temeljnih in perifernih dejavnosti ( $F_{I}$ in $F_{2}$ ).

Za potrebe kvantitativne raziskave oz. anketnega vprašalnika smo, zaradi manjših razhajanj pri opredeljevanju obeh vrst dejavnosti, sami enotno opredelili temeljno in podporno dejavnost bolnišnic ter opredelitev zapisali kot pojasnilo $\mathrm{k}$ tretjemu vprašanju, ki se je nanašalo na značilnosti sprememb. Temeljne dejavnosti smo opredelili kot tiste, ki se nanašajo na procese zdravljenja in diagnostike, zdravstvene nege in rehabilitacije ter na izobraževalno in raziskovalno dejavnost. Podporne dejavnosti pa smo opredelili kot tiste, ki se nanašajo na druge zdravstvene dejavnosti (različne laboratorije, lekarno), na nemedicinsko oskrbo ter upravno-administrativne, tehnične in druge storitve. Po svoji opredelitvi diagnostično dejavnost ter fizioterapijo štejemo med temeljne dejavnosti, laboratorije pa med podporne dejavnosti. 


\section{Področja in vrste radikalnih sprememb}

Spremembe, ki jih v bolnišnicah izvajajo, se dotikajo tako temeljnih kot tudi podpornih procesov. Korenite spremembe nekateri avtorji, kot npr. Porras in Robertson (1992, v Burke 2002, I29-3I) imenujejo tudi revolucionarne. To so spremembe, ki temeljito pretresejo obstoječe prakse in vplivajo na celotno dogajanje v bolnišnicah.

Po opredelitvi temeljnih in perifernih dejavnosti nas je zanimalo, kako v bolnišnicah razumejo radikalne spremembe obeh področij dejavnosti. Zanimalo nas je tudi, katere vrste radikalnih sprememb so izvajali v zadnjih treh letih. Mnogi intervjuvanci ( $\mathrm{A}_{1}, \mathrm{~A}_{2}, \mathrm{~B}_{2}, \mathrm{C}_{2}, \mathrm{C}_{3}, \mathrm{D}_{3}, \mathrm{~F}_{1}$, $\mathrm{F}_{3}$, $\mathrm{G}_{\mathrm{I}}$ in $\mathrm{H}_{2}$ ) so radikalne spremembe temeljnih dejavnosti razumeli bodisi kot njihovo ukinjanje ali uvajanje novih bodisi kot njihovo revolucionarno spreminjanje, kot npr. spreminjanje organizacije bolnišnice zaradi podiranja mej med oddelki in njihovega združevanja. Skupina BI radikalne spremembe razume kot reformo, intervjuvanci v skupini $\mathrm{B}_{2}$ pa kot drastično spreminjanje programov in popolnoma novo politiko vodenja. Intervjuvanci $C_{\text {I }}$ radikalne spremembe temeljnih dejavnosti razumejo kot velike spremembe načinov zdravljenja, lahko kot uvajanje novih diagnostičnih metod, lahko kot novo strategijo ali nov program. Med tako drastičnimi spremembami so izpostavili uvedbo robotskih operacij, ki so zamenjale ročno operiranje. Povedali so, da radikalno spremembo povezujejo $\mathrm{z}$ večjo hitrostjo njenega uvajanja od običajnih sprememb in da ta sprememba zahteva veliko energije ter prilagajanja zaposlenih. Nekateri intervjuvanci so se pri opredeljevanju radikalnih sprememb oprli na strateški dokument, tj. »Strategijo razvoja bolnišnice« $\left(\mathrm{HI}_{\mathrm{I}}\right)$, drugi pa na vizijo bolnišnice (Di), ki je v nekem delu lahko napisana, v drugem delu pa ne. Intervjuvanec $\mathrm{H}_{\mathrm{r}}$ je povedal, da so že leta 2012 pripravili strategijo razvoja do leta 2020 , ki jo vsako leto revidirajo. V njej so določili tiste temeljne spremembe, ki naj bi se zgodile tako v temeljnih kot v podpornih dejavnostih. Določili so strateške projekte, kamor sodi oblikovanje treh stebrov:

- prvi steber je oblikovanje modernega diagnostičnega centra;

- drugi steber je oblikovanje urgentnega centra;

- tretji steber pa je preoblikovanje temeljnih bolnišničnih dejavnosti, predvsem oddelčnih.

Strategijo so uvedli tako, da so najprej pozvali oddelke in druge enote $\mathrm{k}$ pripravi ocene (analize) dejanskega stanja in potem $\mathrm{k}$ pripravi predlogov sprememb (kratkoročnih, srednjeročnih in dolgoročnih oz. bolj strateških). Po prejemu analize je ožji tim obdelal podatke in pripravil osnutek 
strategije, ki pa so ga ponovno pregledali in dopolnili v posameznih organizacijskih enotah. Predlog strategije so poslali v širšo javno razpravo, ne samo članom sveta zavoda, ki so odločali na koncu, ampak tudi sindikalnim enotam. Po vseh občinah v njihovem gravitacijskem območju so za občane organizirali predstavitve.

Intervjuvanci so navajali veliko vrst radikalno temeljnih sprememb, ki so jih izvajali v zadnjih treh letih. Skupina A ı je izpostavila uvedbo novega programa invazivne diagnostike, $s$ katero so izboljšali oskrbo pacientov. Druga radikalna sprememba je uvedba novega urgentnega centra. $\mathrm{Z}$ njegovo postavitvijo so pridobili dodatne prostore. Sprememba pomeni združevanje zdravnikov primarne ravni z zdravniki iz bolnišnice; sekundarna raven, kar je velika sprememba $v$ miselnosti in organizaciji, saj bodo internisti iz bolnišnice, ki so bili do sedaj svet zase in so delovali v drugi stavbi, ter kirurgi po novem delovali skupaj. Imeli bodo skupno triažo, skupen vhod, tudi obravnava bolnika bo po potrebi skupna. Zadeve se organizacijsko in procesno zelo spreminjajo. Združita se dve dejavnosti, internistična in kirurška, vsaka s svojim načinom dela, kirurško dejavnost vodijo anestezisti, internistično internisti, ampak po novem bodo morali delovati kot ena enota. Omenili so tudi združevanje dermatološkega, infekcijskega in pljučnega oddelka kot treh specialnosti, ki so prej delovale vsaka zase. Pomembna sprememba je tudi na področju okulistike, ki je postala dejavnost, ki se opravlja $\mathrm{v}$ dnevni bolnišnici in specialističnoambulantni obravnavi in ne več $\mathrm{v}$ velikem bolnišničnem oddelku. Ista skupina je izpostavila, da je radikalne spremembe povzročilo tudi varčevanje kot posledica $\gg$ Zakona za uravnoteženje javnih financ «. Omenjeno varčevanje je skupina $\mathrm{B}_{2}$ prikazala kot $\gg$ delati več za manj denarja . Povedali so, da je v kriznih časih zdravstvo zelo veliko privarčevalo. Števila zaposlenih kljub omejitvam niso zmanjšali. Mnogo dejavnosti so skrčili na dnevno bolnišnico in privarčevali pri bolnišničnih oskrbnih dnevih. So pa odprli ortopedski oddelek, kar je povzročilo določene strukturne spremembe v kirurgiji.

Urgenco so številne bolnišnice ( $A_{1}, A_{2}, B_{2}, B_{3}, C_{2}, C_{3}, G_{3}$ in $\mathrm{H}_{2}$ ) navajale kot radikalno spremembo temeljnih dejavnosti. Med našo raziskavo so se ravno uvajali novi urgentni centri v vseh petih preučevanih splošnih bolnišnicah.

V bolnišnici C so ugotovili, da bolnikova pot ni ustrezna in da se izgublja v labirintu oddelkov, ki med sabo niso dovolj povezani, zato so ustanovili novo organizacijsko enoto, ki ga v celoti vodi skozi obravnavo in mu priskrbi termine ter potrebne celovite informacije. Skupina $C_{I}$ je spremembo opredelila kot radikalno temeljno spremembo. Tudi skupina 
$\mathrm{D}_{3}$ je navedla odprtje novega oddelka za zdravljenje ene izmed bolezni $s$ svojega specialističnega področja.

Nekatere skupine intervjuvancev (EI, E2 in $\mathrm{D}_{2}$ ) sprememb, ki so jih izvajali v svojih temeljnih dejavnostih, niso zaznavali kot radikalnih. Povedali so, da veliko stvari spreminjajo, vendar ne radikalno, ker revolucionarnim spremembam naročnik ne bi sledil v smislu financiranja teh sprememb.

Med pomembne radikalne spremembe so intervjuvanci $\mathrm{B}_{2}, \mathrm{~B}_{3}$, $\mathrm{D}_{1}$, $\mathrm{F}_{2}$ in $\mathrm{H}_{3}$ uvrstili prvo leto uvajanja ISO-standarda ter mednarodne akreditacije za bolnišnice. Čeprav so za kakovost skrbeli že prej, je uvedba standarda ISO in akreditacije pomenila drastično povečanje administriranja.

Med radikalne spremembe temeljnih dejavnosti so intervjuvanci uvrščali še naslednje:

- spremembe informacijskih sistemov (A2);

- uvajanje večjih novosti v izvajanju zdravstvene dejavnosti $\left(A_{3}\right)$;

- nove programe na rentgenskem oddelku $\left(\mathrm{B}_{2}\right)$;

- uvedbo novega programa žilne dejavnosti ( $C_{1}, G_{I}$ in $\left.G_{2}\right)$;

- robotske operacije na področju urologije $\left(\mathrm{C}_{2}\right.$ in $\left.\mathrm{C}_{3}\right)$;

- delitev oddelka na akutni del in pljučno rehabilitacijo $\left(\mathrm{F}_{3}\right)$.

Iz analize podatkov izhajajo naslednje skupne značilnosti in vrste radikalno temeljnih sprememb:

- korenita reorganizacija oddelkov, ki opravljajo temeljno dejavnost;

- sprememba temeljnega programa oddelka ali bolnišnice;

- korenita sprememba načinov dela $\mathrm{v}$ temeljnih procesih oz. dejavnostih;

- uvedba nove temeljne dejavnosti oddelka oz. bolnišnice ali prekinitev stare dejavnosti.

Radikalne spremembe v perifernih dejavnostih skupini intervjuvancev $A_{I}$ in Gi razumeta kot dejavnosti, ki jih lahko organizirajo z zunanjim izvajalcem. Posebnih sprememb na tem področju niso izvajali. V bolnišnici A so kompletno čiščenje pred leti prenesli na zunanjega izvajalca, odločitev se ni izkazala za najboljšo, zato so ga »vzeli nazaj«. Tudi skupina intervjuvancev $F_{I}$ je izpostavila izločitev pralnice iz svojih dejavnosti. Intervjuvanci $\mathrm{A}_{3}$ so povedali, da so radikalno periferne spremembe posledica radikalno temeljnih. Navedli so primer javnih naročil. Če se radikalno spremeni katera od temeljnih dejavnosti, potem so tudi pritiski na službo za javna naročila večji. 
Intervjuvanci A2 so izpostavili, da zahteve po radikalnih spremembah prihajajo od zunaj, zahtevata jih Ministrstvo za zdravje in Zavod za zdravstveno zavarovanje. V mnogih bolnišnicah ( $\mathrm{B}_{1}, \mathrm{C}_{2}, \mathrm{D}_{1}, \mathrm{D}_{2}$ in $\mathrm{D}_{3}$ ) so ugotavljali, da je bil z varčevalnimi ukrepi, ki jih je predpisal ZUJF (»Zakon za uravnoteženje javnih financ«, Ur. l. RS 40/ı2, I0s/ı2), največji pritisk na zmanjševanje kadra v podpornih dejavnostih. V bolnišnici B so razmišljali, da bi tudi vzdrževanje organizirali preko zunanjega izvajalca, pa so si kasneje premislili, so pa drastično zmanjšali število zaposlenih v tej službi. Skupina $C_{2}$ je navedla, da je omejevanje zaposlovanja v podpornih službah vplivalo na slabšo kakovost storitev in zaradi prevelike obremenjenosti kadra povečalo bolniške odsotnosti. Spet drugi pa so pridelali velik presežek delovnih ur. Kot je povedal direktor Di:

...kadra ni enostavno krčiti, ker moraš zdržati in moraš imeti vseeno rezultate. Delali smo mehko transformacijo, z upokojitvami in odhodi.

Izpad kadra so nadomeščali s študentskim delom, vendar študentje ne predstavljajo zadosti kvalificirane delovne sile.

Nekatere skupine intervjuvancev ( $\mathrm{B}_{2}, \mathrm{C}_{1}, \mathrm{C}_{3}, \mathrm{E}_{2}, \mathrm{E}_{3}, \mathrm{G}_{1}$ in $\mathrm{H}_{3}$ ) so med radikalno periferne spremembe uvrstile uvajanje novih informacijskih sistemov ali njihovo nadgradnjo (npr. elektronsko registracijo delovnega časa).

Med radikalne spremembe perifernih dejavnosti so intervjuvanci uvrščali še naslednje:

- uvedbo e-izobraževanja za zaposlene $\left(\mathrm{C}_{3}\right)$;

- uvedbo e-poslovanja in e-računov $\left(\mathrm{B}_{3}\right)$;

- spremembe organizacije dela v podpornih dejavnostih; ukinili so lokacijsko razpršenost upravnih služb $\left(\mathrm{B}_{2}, \mathrm{~F}_{3}\right)$;

- interno naročanje preko računalnika $\left(\mathrm{F}_{3}\right)$;

- centralizacijo zdravstvene administracije kot posledice pomanjkanja kadra; z enega mesta se kadrovsko pokriva več delovišč oz. oddelkov (A2).

Iz analize podatkov izhajajo naslednje skupne značilnosti in vrste radikalno perifernih sprememb:

- nadgradnja obstoječega informacijskega sistema;

- $\quad$ korenita sprememba procesov dela v podpornih dejavnostih;

- uvedba novega informacijskega sistema;

- uvedba nove podporne dejavnosti. 
Analiza podatkov o radikalnih spremembah nam je poleg globokega vpogleda $v$ področja in vrste omenjenih sprememb predstavljala tudi osnovo za določitev indikatorjev $\mathrm{v}$ delu anketnega vprašalnika, $\mathrm{s}$ katerimi smo merili radikalno temeljne in radikalno periferne spremembe $\mathrm{v}$ kvantitativnem delu raziskave.

\section{Področja in vrste inkrementalnih sprememb}

Značilnost inkrementalnih sprememb je njihova postopnost, premikanje korak za korakom do končnega cilja. Burke $(2002,70)$ jih imenuje tudi evolucijske. Pennington $(2003,4)$ pravi, da jih zaposleni zaznavajo kot samoumevne. Včasih se sploh niti ne zavedajo, da gre pri tej postopnosti za spremembe. Vendar pogled nazaj lahko prikaže drugačno sliko in se skozi daljše obdobje opazi bistvena razlika med tem, kje je bila bolnišnica včasih in kje je sedaj.

Intervjuvance smo vprašali, kako razumejo inkrementalne spremembe na področju temeljnih in perifernih dejavnosti. Prosili smo jih tudi, da opredelijo, katere spremembe uvrščajo med inkrementalno temeljne in inkrementalno periferne.

Intervjuvanci $\mathrm{E}_{2}$ in $\mathrm{E}_{3}$ so inkrementalne spremembe opredelili kot nevidne spremembe, ki se poznajo čez čas. Zanje sta potrebni neka odločitev in smer, $\mathrm{v}$ katero je treba iti. Izpostavili so uvedbo sistema kakovosti. Ko se uvede, potem sistem sam sebe poganja. Zanimiv pogled je predstavil intervjuvanec Hı. Navajamo njegov opis inkrementalnih sprememb:

Dogajajo se vsakodnevno in jih v zdravstvu sploh ne priznavamo. To so novosti, izboljšave. Uvedba neke oblike stalne pripravljenosti sester za spremstva je taka sprememba, za katero bi nekdo rekel, da je čisto nepomembna. Ampak lahko ti podre izvajanje dejavnosti na vseh temeljnih oddelkih, zelo hitro. Npr., druga bi bila uvajanje pojasnilnih obrazcev v postopek zdravljenja. Od tega, da smo se najprej ukvarjali s formo teh obrazcev, do tega, da smo potem določili, na kakšen način je treba obrazce izpolnjevati, do tega, da smo potem prišli v fazo, kje se jih shranjuje, da so se o tem izvajale notranje kontrole na oddelkih, da se je zagotovilo vsaj neko dosledno izpolnjevanje teh obrazcev, in končno zavedanje, da so ti obrazci zelo velikokrat v odškodninskih sporih, ali pa v kakšnih izrednih strokovnih nadzorih, ali pa v postopkih pred sodišči, ključnega pomena.

Skupina intervjuvancev Aı je ugotavljala, da so inkrementalno temeljne spremembe $\mathrm{v}$ bolnišnici bolj $\mathrm{v}$ ingerenci vodij posameznih dejavnosti, to so npr. novi postopki, pristopi in načini dela, ki se dogajajo kontinuirano. Drugo področje pa so videli kot posledico razvoja stroke, ki 
vključuje tehnološki razvoj in razvoj farmacije. Tudi skupina $\mathrm{D}_{2}$ je izpostavila razvoj stroke. Kot so povedali, so naredili veliko sprememb v funkcionalni diagnostiki in laboratorijskih preiskavah.

Intervjuvanci v mnogih bolnišnicah $\left(\mathrm{A}_{1}, \mathrm{~A}_{2}, \mathrm{~B}_{1}, \mathrm{D}_{1}, \mathrm{D}_{2}, \mathrm{D}_{3}, \mathrm{~F}_{1}, \mathrm{~F}_{3}\right.$, $\mathrm{G}_{\mathrm{I}}$ in $\mathrm{H}_{2}$ ) so inkrementalne spremembe temeljnih dejavnosti povezovali s kakovostjo, ki se zagotovo uvaja daljše časovno obdobje. Rezultati niso vidni takoj, ker je treba krepiti zavest posameznikov. Akreditacija bolnišnic in vpeljava ISO-standarda sta povzročili uvedbo mnogih obrazcev, ki se kažejo v povečanju administrativnega dela, vendar so koristi precejšnje.

Med inkrementalne spremembe temeljnih dejavnosti so intervjuvanci uvrščali še naslednje:

- zgodnjo prepoznavo ogroženega pacienta, kar je ena najpomembnejših stvari, $s$ katero zmanjšujejo umrljivost in stroške zdravljenja (AI);

- uvajanje zgodnjega okrevanja po operaciji, s katerim zmanjšujejo ležalno dobo v bolnišnici, ter uvedba zdravljenja bolečine (AI in EI);

- uvajanje digitalizacije rentgena (A2);

- večji nadzor nad zdravili $\left(\mathrm{A}_{3}\right)$;

- uvajanje kliničnih poti in pisanje protokolov $\left(\mathrm{BI}_{\mathrm{I}}\right)$;

- 7-ro-urni delovnik se spremeni na 8-urni delovnik; želeli so razbremeniti tiste v nočni izmeni; dežurstva prehajajo na izmensko delo (CI);

- zvočni zapis oz. nov način diktiranja izvidov $\left(\mathrm{C}_{2}\right.$ in $\left.\mathrm{C}_{3}\right)$.

Iz analize podatkov izhajajo naslednje skupne značilnosti in vrste inkrementalno temeljnih sprememb:

- sprememba metod zdravljenja ali diagnosticiranja;

- uvedba novega zdravstvenega programa (brez pretresov ali motenj);

- stalno izboljševanje kakovosti;

- optimizacija organizacije dela v temeljnih dejavnostih;

- sprememba metod dela.

Nekateri intervjuvanci so inkrementalne spremembe perifernih dejavnosti opisali kot samoumevne, ki se jih tako na hitro zelo težko spomnijo ( $\mathrm{A}_{\mathrm{I}}$ ). Drugi so jih opisovali kot $\gg$ dejstvo, ki ga sprejmeš in greš dalje«. (A3). Skupina $\mathrm{C}_{2}$ jih je opredelila kot stalnico. Tudi skupina $\mathrm{D}_{2}$ jih je opredelila kot stalno prilagajanje, ki včasih prinese večje ali manjše obremenitve. Menijo, da vsekakor predstavljajo neko racionalizacijo. In- 
tervjuvanec $\mathrm{H}_{\mathrm{i}}$ je dejal, da so to spremembe, na katere te morda bolnik spomni v soboto na tržnici, ko reče: »Joj, koliko se je pri vas spremenilo, ste to pa to naredili.«

Med inkrementalne spremembe perifernih dejavnosti so intervjuvanci uvrščali še naslednje:

- povečanje administrativnega dela kot posledica zakonodaje $\left(A_{3}\right)$;

- vključevanje farmacevtov v delo na oddelku (Ar);

- neprestano nadgrajevanje računalniških programov (A2);

- centralno razdeljevalnico osebnega perila (CI);

- uvajanje e-računov $\left(B_{2}, B_{3}\right.$ in $\left.C_{3}\right)$;

- uvedbo davčnih blagajn in ponudbo prehranskih storitev za trg $\left(\mathrm{C}_{2}\right)$;

- postopno spreminjanje načinov dela v podpornih procesih $\left(\mathrm{D}_{3}\right)$.

Iz analize podatkov izhajajo naslednje skupne značilnosti in vrste inkrementalno perifernih sprememb:

- sprememba postopkov dela, vezanih na podporne dejavnosti;

- stalno izboljševanje podpornih dejavnosti;

- optimizacija procesov dela $\mathrm{v}$ podpornih dejavnostih;

- sprememba administrativnih postopkov;

- nadgradnja informacijskega sistema.

Analiza podatkov o inkrementalnih spremembah nam je prav tako predstavljala podlago za določitev indikatorjev nove merske lestvice za merjenje vrste sprememb v bolnišnicah. Poleg vrste sprememb so nas zanimale tudi značilnosti procesov spreminjanja, ki jih opisujemo v naslednjem poglavju.

\section{Značilnosti procesov spreminjanja}

Eden izmed ključnih ciljev raziskave je pridobiti poglobljen vpogled $\mathrm{v}$ značilnosti procesov spreminjanja v bolnišnicah. Zato smo s pripravljenimi izhodiščnimi vprašanji potek intervjujev usmerili v:

- ugotavljanje samega izvajanja sprememb,

- prepoznavanje motenj,

- identifikacijo morebitnih tveganj,

- prepoznavanje odporov in soočanje z njimi,

- prepoznavanje najtežjega dela pri izvajanju sprememb.

$\mathrm{V}$ bolnišnici A so $\mathrm{k}$ radikalnim spremembam pristopali načrtno oz. strateško. Intervjuvanci $A_{I}$ so povedali, da so v »Strateškem načrtu« 
opredelili potrebe po združevanju oddelkov. Po sprejetju »Strateškega načrta $\ll$ in $\gg$ Letnega načrta so opravili veliko razgovorov na strokovnem svetu, svetu zavoda, kolegiju glavnih medicinskih sester, oddelčnih sestankih in timskih sestankih. Poslovnega tveganja v smislu financ niso zaznali, največja težava so bili zaposleni, ki so morali spremeniti miselnost. Bistvo radikalnih sprememb so izboljšave za bolnike in na daljši rok tudi za zaposlene. $\mathrm{Z}$ učinkovito komunikacijo so morali izpostaviti vse prednosti sprememb. Ko so jih zaposleni sprejeli, je ves proces stekel. Predvsem pri zdravnikih brez dobrega pogovarjanja ne gre, ker hitro najdejo različne ovire. Za radikalno spremembo potrebujejo čas, da z razmislekom pridejo do zaključkov, kako narediti, da bo najboljše za vse (bolnišnico, bolnike in zaposlene). Do soglasja, strinjanja oz. prevzemanja idej ne pride takoj, ampak je treba nujnost in smiselnost sprememb ves čas poudarjati. Najtežji del je predstavljalo preseganje trenutne miselnosti, da delajo dobro in da spremembe niso potrebne. Nekateri ljudje se sprememb otepajo, ne sprejmejo jih zlahka. Večjih odporov niso zaznavali, bolj neko obliko zadržanosti. Kot so povedali, so včasih sindikati tisti, ki ovirajo. Zaposleni hitro izražajo nezadovoljstvo. Če pa se po eni strani počutijo še zaščiteni in varni s splošno zaposlitvijo $\mathrm{v}$ zdravstvu, potem je negodovanje večje. Skupina je tudi povedala, da so v nekaterih sredinah novosti lažje uvedli. Menijo, da je zaposlitev danes večja vrednota, in ker služb ni ravno na pretek, še posebej ne za suficitaren kader, so ljudje odgovorneje pristopali $k$ projektom sprememb.

Skupina A2 pa je povedala, da so si pri uvajanju radikalnih sprememb pomagali z različnimi izobraževanji, predvsem iz informatike. Izvedli so številne delavnice, tudi individualno so informatiki prihajali v ambulante in usposabljali zaposlene. Poudarili so informiranje glede sprememb. Primer urgence je zahteval komunikacijo med uporabniki na eni in projektanti na drugi strani. Odpori so bili prisotni, vendar predvsem zaradi strahu. Najbolj so se zaposleni uprli zaradi notranjega kadrovanja. Malo starejši delavci, ki delajo na istem oddelku že več kot 20 let, težko odidejo na drugo delovno mesto. Težava nastane na primer, če mora kakšna izkušena medicinska sestra $\mathrm{z}$ oddelka na urgenco. Takih sprememb si malokdo želi. Poudarili so tudi, da je glede sprememb najprej treba imeti cilj in ga posredovati zaposlenim tako, da se čutijo koristne. Prav tako mora biti vodja prepričan v koristnost novosti - le tako bo lahko verodostojno prepričal druge. Menili so, da so radikalne spremembe predstavljale veliko tveganje. Izpostavili so uvedbo beleženja zdravil na bolnika. Vsi so dobili računalnik, organizirali so tudi stroškovna mesta. Tveganje so predstavljali napačni vnosi vrste zdravil, količin ipd. Kasneje so se zapos- 
leni navadili, ampak med uvajanjem je to predstavljalo veliko tveganje. Najtežji del so predstavljali: negotovost pred začetkom spremembe, sam začetek in jasna navodila oz. njihovo razumevanje. Skupina $\mathrm{A}_{3}$ je glede motenj in tveganj povedala, da so bili prisotni predvsem na začetku zaradi večjega obsega dela. Povedali so tudi, da so jih vodje vključevali v iskanje rešitev in da so se o spremembah veliko pogovarjali. Tudi informiranja je bilo veliko. Večjih pritiskov s strani vodij niso čutili. Mogoče so občutili kakšne manjše razlike, ker so bili med uvajanjem sprememb nekoliko bolj napeti.

Proces uvajanja inkrementalnih sprememb se bistveno ne razlikuje od uvajanja radikalnih. Skupina Aı je povedala, da so koraki podobni: več izobraževanja o novitetah, informiranje zaposlenih in sprotna komunikacija. Tudi skupina A2 ni zaznala razlik. Izpostavili so le počasnejše sprejemanje in učenje računalniških programov pri starejših. Izpostavili so primer, ko je eden izmed zdravnikov vso računalniško evidenco prenesel na administratorko. Sam se z njo ni želel ukvarjati. Skupina $\mathrm{A}_{3}$ pa je povedala, da so inkrementalne spremembe predstavljale manjše tveganje, povzročale pa so enako mero motenj kot radikalne. Sprememb so se lotevali z informiranjem o smiselnosti spremembe in spreminjanjem miselnosti zaposlenih, kar so izpostavili kot najtežje opravilo.

$\mathrm{V}$ bolnišnici B so se glede uvajanja radikalnih sprememb najprej dogovorili v okviru vršnega managementa oz. vodstva bolnišnice. Postavili so si cilj glede spremembe, ki se je dotikala odprtja novega ortopedskega oddelka. Želeli so razviti področje ortopedije. Največje težave so imeli zaradi pomanjkanja specialistov - ortopedov in pa priznavanja oz. financiranja storitve. Ortopedijo so zaposleni videli kot tujek v kirurški zgradbi in to je predstavljalo velike motnje. Vse so opisali na naslednji način:

Pred leti smo v vodstvu prepoznali hudo pomanjkanje v oskrbi ortopedskih pacientov in smo se odločili, da gremo v razvoj ortopedije, čeprav smo strokovnjake, ki bi ortopedski program začeli izvajati, še iskali. Vedeli smo tudi, da na začetku program ne bo financiran. Treba je bilo narediti gromozanske premike v miselnosti zaposlenih na kirurškem oddelku. Počasi smo kader le pridobili, vendar pa nam še vedno ni uspelo uvesti timskega dela med njimi, vsaj ne v taki meri, kot bi si želeli. Težava je bila, da so določeni zaposleni ortopedijo videli kot tujek $v$ kirurški zgradbi.

$\mathrm{Na}$ začetku so intenzivno komunicirali, predvsem s predstojnikom oddelka, in informirali zaposlene. Pojavljali so se odpori, ki so uvajanje ortopedskega programa upočasnili. Večinoma so to bile neke namišljene situacije in grožnje zaposlenih. Včasih je bilo treba kakšno stvar nekoliko 
upočasniti, ker se ni dalo izpeljati niti z zahtevami, včasih pa je bilo treba spremembe zahtevati ali celo vsiliti. Spremembo z ortopedijo je skupina BI izpostavila zato, ker je bila po njihovem videnju najbolj »svetla «. Nekoliko lažje so uvajali radikalne spremembe perifernih dejavnosti. Skupina je izpostavila vzdrževanje. To je služba, ki ne dela neposredno z bolnikom, temveč za bolnika. Drastično so zmanjševali delavce v tej službi. Največje tveganje je predstavljalo to, da bi zaradi zniževanja števila zaposlenih vzdrževanje prevzel zunanji izvajalec, ki pa bi lahko bil še dražji. Odpore pri radikalno perifernih spremembah so zaznali kot manjše v primerjavi z odpori pri radikalno temeljnih spremembah. Predvidevali so, da verjetno zaradi zavedanja, da je na tržišču teh delavcev več, ali pa so zaposleni v vzdrževanju uvideli, da so bili prej kadrovsko malo bogatejši, kot bi sicer lahko bili.

Skupina vodij $\mathrm{B}_{2}$ je kot radikalno spremembo izpostavila akreditacijo. Odločitev za pridobitev akreditacije je sprejelo vodstvo, vodje pa so to odločitev morali predstaviti zaposlenim na pozitiven način, v smislu, da bodo izboljšali kakovost in da bo to kasneje pomenilo lažje delo. Največjo motnjo je predstavljalo dodatno delo. Ker so bili zaposleni navajeni določenih rutin, je bila vsaka sprememba motnja. Odpore so premagovali z razgovori s posamezniki. Na sestankih s prepričevanjem niso uspeli, hitro so bili nekateri proti in so $\mathrm{k}$ temu pritegnili tudi druge. Vodje so morali biti prepričljivi, prikazovati prednosti spremembe in zaposlene motivirati zanjo.

Intervjuvanci $\mathrm{B}_{3}$ so povedali:

Pri uvajanju radikalnih sprememb smo pogrešali informiranje, vključenost v razgovore oz. v pripravo na spremembe ter jasne smernice v zvezi s spremembo.

Intervjuvanci $\mathrm{B}_{\mathrm{I}}$ so povedali, da se način izvajanja inkrementalnih sprememb ni razlikoval od načina izvajanja radikalnih sprememb. Je pa bilo pri inkrementalno perifernih spremembah najmanj težav. Največ odporov za spremembe so zaznali pri zdravnikih, saj ta poklicna skupina najtežje spreminja ustaljene načine dela. V spremembi morajo videti smisel, potem jo sprejmejo. Enako so ugotavljali intervjuvanci B2, namreč da so bili pri uvajanju elektronske registracije delovnega časa največji odpori pri zdravnikih. Menili so, da so motnje enake ne glede na vrsto sprememb, da pa je tveganje večje pri radikalnih spremembah.

Skupina Ci je povedala, da so se na radikalne spremembe pripravljali dlje. Zaposlene so informirali o njihovi novi vlogi oz. o tem, kaj jim bodo spremembe prinesle. Zavedali so se pomembnosti stalne komunika- 
cije in osveščanja zaposlenih z namenom, da sprejmejo načrtovane spremembe. Spremembe so dobro načrtovali in jasno razložili vzroke zanje. Ob morebitnih težavah so hitro ukrepali in imeli zanje pripravljene scenarije. Spremembe so predstavljale finančno tveganje ter tveganje pri izbiri ustreznega kadra. Sprememba iz statične organiziranosti v procesno organiziranost je zahtevala veliko usklajevanja, kar je predstavljalo najtežji del. Vodstvo je spodbujalo, da so rešitve prihajale iz sredin, na katere je sprememba najbolj vplivala. Največji odpori so se pojavljali pri spremembah, ki jih je zahtevalo ministrstvo, ker so njihove zahteve velikokrat nenaravne. Navedli so primer poročanja o obremenjenosti zdravnikov v dežurstvu. Menda se na ministrstvu s temi podatki niso ukvarjali. Z zelo hudimi odpori so se soočali pri uvedbi elektronske registracije delovnega časa. Predvsem zdravniki so menili, da se jim jemlje integriteta. Prišlo je skoraj do upora zaradi hujskanja, da je treba razbiti vse registracijske naprave pri vhodih, vendar je na koncu le prevladala zdrava pamet. Zdravniki so poklicna skupina, ki ima poseben status v naši družbi in neverjetno moč. Kot so povedali intervjuvanci, lahko spreminjajo politiko ali vržejo vlado. Zdravstveni sistem v Sloveniji je tako občutljiv, da že kratkotrajna stavka zdravnikov lahko zamaje marsikoga. To pa je prostor, ki omogoča izsiljevanje.

Intervjuvanci $C_{I}$ so povedali, da so imeli projektni tim za uvajanje spremembe. K sodelovanju so želeli pritegniti karizmatične vodje, ki potem za seboj potegnejo večino zaposlenih. $S$ komunikacijo so začeli bistveno prej kot s samimi postopki. Imeli so izjemno veliko sestankov, o spremembah so pisali v internem časopisu. Vnaprej so opredelili vsa tveganja, ki so jih reševali sprotno. Organizirali so številna izobraževanja. Bili so vztrajni, zato je sprememba tudi uspela. Skupina $C_{2}$ je izpostavila, da so spremembe nepriljubljene tudi za vodje. Predstavljajo motnje in povzročajo težave, ki jih je treba sproti reševati. Zaposleni jih doživljajo zelo stresno, saj so njihovi nujni spremljevalci prepiri in slaba volja. Izpostavili so predvsem zaposlene $\mathrm{v}$ zdravstveni negi in urgenco kot primer radikalne spremembe. Imeli so tedenske sestanke, na katerih so se sproti dogovarjali, kaj je treba narediti, vendar so imeli glede na postavljene roke Ministrstva za zdravje premalo časa. Postavljeni roki so bili posledica sredstev, ki so jih prejeli iz Evropske unije. Projekt novih urgentnih centrov je bil nacionalni in ne bolnišnični. Ena izmed vodij v skupini $\mathrm{C}_{2}$ je povedala, da je pomemben zgolj datum, vsebina pa ne. Za dodatno opravljeno delo pa ni nobenega nagrajevanja. Kot vodje lahko svoje zaposlene nagradijo le $s$ tem, da jih poslušajo in upoštevajo ter da jim odobrijo dopust, če delovni proces to dopušča. Povedali so, da tudi z ISO-stan- 
dardom zaposleni niso vsega sprejeli, predvsem notranjih presoj in vpeljavo nekaterih dokumentov. Vodje morajo veliko energije vlagati v to, da jih prepričajo. Dela in nalog je več, z delavci pa so številčno omejeni. Skupina zaposlenih $\mathrm{C}_{3}$ je povedala, da so pri uvajanju radikalnih sprememb prejeli ustne informacije pa tudi veliko pisnih navodil. Izpostavili so elektronsko evidentiranje delovnega časa. Pogrešali pa so še več sestankov in več informiranja, kar je eden izmed intervjuvancev ponazoril z besedami:

...tista beseda, ki jo poveš, je čisto nekaj drugega, kot pa tisto, kar je v alinejah napisano, in si nekaterih stvari ne znaš niti pravilno razlagati.

Spet drugi intervjuvanec iz vrst zaposlenih je povedal, da se zaposleni držijo svojega oklepa, ker jih je strah, da bodo s spremembo prišli v slabšo situacijo ali da ne bodo zmogli. Priznal je tudi, da je ta strah večinoma posledica nevednosti in neznanja $\mathrm{v}$ tistem trenutku. Rutina vsekakor pomirja, takrat se ljudje počutijo varne. Delo po utečenih tirnicah ne zahteva naprezanja, pri spremembah pa je treba vložiti dodaten napor, kljub nejasnosti, kaj bo sprememba prinesla. Nekateri ljudje se že pri rutinskem delu počutijo zelo obremenjeno. Intervjuvanci $\mathrm{C}_{3}$ so povedali, da bi jim bilo mnogo lažje, če bi jim predstavili vizijo oz. prihodnjo sliko te spremembe. Situacijo so ponazorili s primerom na bolniku. Tudi zanj je mnogo lažje, če dobi vse informacije, ki jih v določenem trenutku potrebuje, npr. kaj lahko pričakuje oz. kaj lahko naredi. Te informacije potrebuje, ker ga pomirijo. Prav tako je z zaposlenimi med uvajanjem sprememb. Intervjuvanci niso opazili bistvenih razlik $\mathrm{v}$ procesih uvajanja radikalno temeljnih, radikalno perifernih, inkrementalno temeljnih ter inkrementalno perifernih sprememb.

$\mathrm{V}$ bolnišnici $\mathrm{D}$ so med uvajanjem sprememb veliko pozornosti namenili argumentirani komunikaciji. Pomagala jim je tudi pri soočanju z odpori. Za spremembe so zadolžili sposobne posameznike, ki so $\mathrm{v}$ spremembe verjeli, se zavedali svoje velike odgovornosti in ji posvetili vso pozornost. Pri spremembah so vztrajali in šli do končnega cilja. Ob problemih so takoj ukrepali. Ves čas so razvijali nove pristope pri zdravljenju bolnikov. Čeprav so tveganja zapisali v register tveganj, jih niso občutili kot močna. Izhajali so iz svojih praktičnih izkušenj, na podlagi poznavanja procesov. V spremembe niso šli na slepo. Pri inkrementalnih spremembah perifernih dejavnosti so zaznali večje odpore zaradi vmešavanja sindikata. Inkrementalno temeljne spremembe so stalnica, zato so bili tukaj odpori večji, pa ne odkriti, temveč bolj prikriti. Intervjuvanec Di je dejal, da so pač časi, ko vsak gleda nase. Soočanje s prikritimi odpori in njihovo premagovanje pa traja dlje časa. Takoj so prepoznali nasprotni- 
ke sprememb. Bili so zelo sovražno nastrojeni in manipulativni. Z njimi pa se niso preveč obremenjevali. Skupina $\mathrm{D}_{2}$ je povedala, da so imeli težave zaradi zmanjševanja števila zaposlenih, preostali zaposleni so bili velikokrat preobremenjeni. Iskali so notranjo racionalizacijo. Prizadevali so si tudi za razvoj stroke. So pa zaposleni težko razumeli, zakaj je potrebnih toliko novih obrazcev. Niso videli koristi ne zase ne za bolnike. Skupina je povedala, da večjih odporov niso zaznali. Najtežji del jim je predstavljala sama priprava na spremembe, v katero so vključili prepričevanje zaposlenih in pridobivanje njihove podpore za spremembo. Na sestanke so povabili strokovnjake različnih področij, da so potem lažje naredili načrt spremembe oz. strategijo. Vse spremembe so občutili kot motnje, vedno se je bilo treba prilagajati. Skupina $\mathrm{D}_{3}$ je povedala, da je radikalno temeljna sprememba zahtevala obširno predpripravo, ki je vključevala pripravo novega programa oz. dejavnosti oddelka, zagotovitev novih delavcev ter prerazporeditev že zaposlenih. Najtežje pri uvajanju te spremembe je bilo pridobiti ustrezne informacije. Skupina je povedala, da so bili odpori pri radikalnih spremembah večji. Vedno so imeli možnost $\mathrm{z}$ vodji razčistiti vse dileme. Zaposleni sprememb ne sprejmejo odprtih rok, se pa prilagodijo, ko je to potrebno, včasih tudi brez hujših konfliktov.

$\mathrm{V}$ bolnišnici E sprememb niso opredelili kot radikalnih. Skupina intervjuvancev $E_{\text {I }}$ je povedala, da so se inkrementalnih sprememb lotili premišljeno. Izpostavili so spremembo, vezano na interdisciplinarno povezovanje znotraj bolnišnice. Imeli so veliko sestankov, na katerih so se dogovorili, kako bodo dosegali cilje, povezane s spremembami. Namen sprememb in cilje so morali pojasnjevati različnim službam ter različnim skupinam zaposlenih. Ko so zaposleni razumeli, da so spremembe nujne za dobrobit bolnika, so jih sprejeli. Največje tveganje je bilo finančno. Če sprememba ne bi uspela, bi imeli slabše finančne rezultate. Skupina je povedala, da je najtežji del predstavljala sprememba kulture delovanja zaposlenih. Niso bili navajeni povezovanja in sodelovanja. Glede odporov je skupina povedala, da je vedno io do is odstotkov ljudi, ki so uporniki. Težava je, če se med njimi znajdejo neformalni vodje, ki za sabo pritegnejo še več nasprotnikov sprememb. Res je tudi, da ljudje težko sprejmejo nekaj, česar ne razumejo. Skupina E2 je povedala, da so pred uvajanjem spremembe najprej naredili analizo stanja, šele potem je sledilo uvajanje. Zaposleni so se morali naučiti veliko novega, pri tem so potrebovali podporo in pomoč vodij. Kot je povedal eden izmed intervjuvancev v skupini E2, so bili delavci pripravljeni na nove izzive, če so jim to primerno sporočili. Intervjuvanci $\mathrm{E}_{3}$ so povedali, da se danes zavedajo, da so bile spre- 
membe nujne in koristne. Med uvajanjem so jim nadrejeni dovolili izražati ustvarjalnost.

V bolnišnici F so uvajali popolnoma novo temeljno dejavnost. Skupina FI je povedala, da so začeli z usposabljanjem oz. ogledom podobne tuje institucije. Ogledali so si njeno funkcioniranje in na osnovi njihovih izkušenj ter lastne vizije pripravili projekt oz. načrt za uvedbo nove dejavnosti v svoji bolnišnici. Bilo je veliko pogovorov, tematiko so uvrstili na strokovni svet. Po potrditvi projekta so začeli uvajanje. Največja motnja je bila slaba opremljenost bolnišnice za nov program, vendar so vztrajali na začrtani poti. Danes se zavedajo, da sta jim neomajnost in vztrajnost zagotovili obstoj. Na začetku je moralo vodstvo postaviti jasne zahteve. Zdravniki niso bili preveč navdušeni, ker z vidika njihove stroke program ni veljal za visoko perspektivnega, je pa omogočil širitev dejavnosti in obstoj bolnišnice. Večjih odporov ni bilo, več je bilo posameznega negodovanja. Huda kriza in boj za preživetje sta zaposlene združila, da so z večjo vnemo sodelovali pri spremembah. Skupina $E_{3}$ je povedala, da jim uvajanje sprememb v začetni fazi ni všeč. Vendar vedo, da morajo sodelovati. Menijo, da se včasih spremembe izkažejo za smiselne, včasih pa tudi ne. Izpostavili so pretirane zahteve po dokumentiranju vsega zaradi ISO-standarda.

$\mathrm{V}$ bolnišnici $\mathrm{G}$ so pri uvajanju radikalno temeljne spremembe (uvajanje nove dejavnosti) imeli največje težave pri organiziranju dela. Skupina Gi je povedala, da se niso mogli dogovoriti, ali nova dejavnost spada h kirurškim ali $\mathrm{k}$ internističnim dejavnostim. Težavo so reševali s konsenzi. Zaposlene so seznanili z novostmi in novo organizacijo dela. Pri elektronskem evidentiranju delovnega časa so naleteli na pogosta pritoževanja. Predvsem zdravnikom nov način evidentiranja ni bil všeč, ker so to občutili kot obliko nadzora. Vodstvo je moralo večkrat razložiti, da ne gre za obliko nadzora, ampak za lajšanje dela, kajti sistem za evidentiranje prisotnosti oz. različnih vrst odsotnosti je povezan s plačnim sistemom, kar omogoča lažji in hitrejši obračun plač. Razen morebitnih zlorab drugih motenj spremenjen način evidentiranja delovnega časa ni povzročil. Težave so reševali z individualnimi razgovori, nikoli skupinsko. Skupina vodij G2 se je jasno zavedala, da morajo zaposlenim razložiti cilje sprememb. Če ne poznajo ozadja, se uprejo. Zaposleni morajo prepoznati, zakaj morajo npr. izpolnjevati dodatne dokumente. Je pa skupina izpostavila, da so zahteve ministrstva velikokrat prepoznali kot nesmiselne. Skupina $\mathrm{G}_{3}$ si v okviru procesa spreminjanja želi: dobro pripravo, organizacijo, podrobna navodila in timsko delo. Želeli bi si tudi več informiranja. Izpostavili so obremenitev zaposlenih kot najtežji del pri uvajanju sprememb. 
$\mathrm{V}$ bolnišnici $\mathrm{H}$ se med spremembami niso ukvarjali z nasprotniki. Pustili so jih ob strani in se osredotočili na podpornike oz. zagovornike sprememb. Skupina $H_{\text {I }}$ je povedala, da so bili presenečeni, ko so ugotovili, kako številčni so zagovorniki. $Z$ njimi so veliko komunicirali, saj so morali ti tudi opraviti zelo veliko dela z zaposlenimi. Skupina je ugotovila, da se spremembe ne morejo zgoditi na hitro in ad hoc. Šele sčasoma se novost usidra $v$ miselnost ljudi in jo sprejmejo kot samoumevno ter del svoje rutine. Zanimiv je pogled te skupine, ki vidi manko v zdravstvenem izobraževalnem sistemu, ker tem profilom ne da neke širine. $V$ njihov študijski program bi bilo treba uvesti predvsem vsebine o komuniciranju pa osnove ekonomike in prava. Skupina $\mathrm{H}_{2}$ je povedala, da so spremembe pazljivo načrtovali, razen lastnikovih zahtev. Menili so, da je bila njihova bolnišnica vedno tarča različnih napadov, celo teženj po ukinjanju. Doživljali so spreminjanje dejavnosti, vendar so strnili vrste in skupaj z akreditacijskimi ekipami uspeli, da so ohranili vse dejavnosti. Izboljšali so kakovost, zaposleni bolje sodelujejo med seboj in postali so močnejši. Predstavniki skupine $\mathrm{H}_{3}$ so se ob toliko novostih počutili kot deseterobojci. Imeli so zadosti informiranja, tudi izobraževanja. Najtežje je bilo preklapljati med različnimi opravili. Pomisleke so imeli tudi ob določenih zahtevah ministrstva, ker so povzročale dodatno delo in obremenjenost zaposlenih.

$S$ kvalitativno raziskavo smo izluščili pomembne značilnosti procesov spreminjanja v bolnišnicah. Mnoge bolnišnice so se na uvajanje sprememb temeljito pripravljale že pred začetkom. Spremembe so načrtovale. Postavile so cilje oz. neko vizijo spremembe. Načrt oz. projekt sprememb je vodstvo nekaterih bolnišnic dalo v širšo obravnavo, kar pomeni, da so v odločanje vključili pomembne deležnike, kot so zaposleni in nadzorniki. Ena bolnišnica je vključila tudi javnost oz. uporabnike svojih storitev. Pozvali so tudi lastnika (Ministrstvo za zdravje) ter financerja (Zavod za zdravstevno zavarovanje), da se opredelita do načrtovanih sprememb. Uvajanja sprememb so se $\mathrm{v}$ vseh bolnišnicah lotevali z ustreznim (dvosmernim) komuniciranjem in s pogostim informiranjem. Kljub temu so zaposleni v nekaterih bolnišnicah povedali, da je bilo občasno informacij premalo in da so jih morali sami pridobiti, včasih celo izven lastne ustanove. Predvsem pri spremembah oz. novostih, ki jih je zahtevalo ministrstvo, niso imeli dovolj informacij. Spremembe so največkrat zahtevale dodatna znanja in usposobljenost zaposlenih. Kot kaže, je bilo izobraževanja dovolj, saj nihče ni omenil, da se ne bi izobraževal. Spremembe so povzročale določene motnje $\mathrm{v}$ delovnih procesih pa tudi nekatera tveganja, vendar jih nikjer niso izpostavili kot zelo problematične. Večina bol- 
nišnic ni zaznala razlik glede motenj in tveganj med različnimi vrstami sprememb. Če pa že, so večje motnje in tveganja pripisovali obema vrstama radikalnih sprememb. Tudi velikih odporov niso imeli, bolj so se soočali z nezadovoljstvom ali apatijo pri zaposlenih. Ko pa so se odpori pojavili, so jih poskušali zmanjševati z razgovori, predvsem individualno, ne v skupinah. Vpeljane spremembe so ocenjevali kot uspešne, predvsem tam, kjer je vodstvo vztrajalo in so vpeljane novosti prišle v rutino.

\section{Pristopik vodenju sprememb}

$\mathrm{V}$ tej kategoriji smo raziskavo usmerili v stile vodenja med uvajanjem sprememb. Zanimalo nas je, ali se ti razlikujejo glede na običajne razmere »status quo «. Želeli smo dobiti vpogled v uspešnejše pristope k vodenju sprememb.

Predstavniki skupine A s so določili vodje, ki so jih zadolžili za uvedbo sprememb. Mnogo nalog so delegirali. Sami so svoj stil vodenja označili kot demokratični. Bolj so se videli kot timski vodje. Še več, opredelili so se kot avtentični vodje, kar je direktorica opisala z naslednjimi besedami:

Pri nas v glavnem uporabljamo bolj mehko vodenje, celo avtentičnega. Vodenje je demokratično, timsko. Pogovarjamo se. Sem pa tja v dejavnostih, kot je intenzivna urgenca, pa mora biti tudi avtokratsko. Takrat, ko je nujno, morajo vedeti, kdo vodi in kaj morajo delati. Takrat ni možnosti za demokracijo, da bi vsak po svoje tekel. Morajo točno videti, kdo vodi in kam ter na kakšen način gremo.

Glede na navedbe intervjuvancev lahko sklepamo, da je prevladujoč stil vodenja demokratični, vendar pa v nujnih ali kriznih situacijah, kot je bil pri njih primer novega urgentnega centra, uporabljajo avtoritativnejši pristop.

Stila vodenja niso prilagajali, le pri radikalno perifernih spremembah so uporabljali še demokratičnejši pristop. Intervjuvanci v skupini A2 niso opredelili stilov vodenja, opisali so le svoj pristop k podrejenim. Povedali so, da je bilo treba komunicirati osebno, nikoli preko elektronske pošte. Sklicevali so sestanke in tam informirali ter istočasno prejemali povratne informacije. Skupina zaposlenih $\mathrm{A}_{3}$ je glede stilov vodenja nadrejenih povedala, da stilov niso prilagajali in da so vodje vodili spremembe na običajen način, saj pri vodenju niso zaznali nobene razlike.

Iz odgovorov vseh skupin v tej bolnišnici lahko sklepamo na mnoge komponente avtentičnega vodenja, ki so jih opredelili Walumbwa idr. $(2008,95)$. Prva komponenta je samozavedanje glede svojih prednosti in 
slabosti. Management v tej bolnišnici zna pošteno pogledati vase in deluje na podlagi moralne perspektive, ki jo je ponotranjil in je ni vsilila določena skupina ali oblast.

Tudi vodilni v bolnišnici B so med spremembami uporabili demokratični slog vodenja, kar so ponazorili z besedami:

\section{Na začetku smo bili kar se da demokratični. Smo parlamentarizirali, se veli- \\ ko pogovarjali in iskali rešitve. Potem pa je bilo treba kakšno stvar enostav- no zahtevati. Interesi so se začeli razhajati. Takrat pa mora vedno biti kdo, ki na koncu pove zadnjo besedo.}

Povedali so, da so morali nastopiti tudi avtoritativno in od podrejenih zahtevati, da zadeve premaknejo z mrtve točke. Skupina vodij B2 je uporabila mehak pristop. Kot so dejali, svoje sodelavce dobro poznajo in vedo, kako je treba pristopiti in kdaj je potrebna pohvala. Ta ima resnično velik učinek. Skupina zaposlenih $\mathrm{B}_{3}$ je pohvalila podporo, ki so jo nudili njihovi vodje, čeprav so nastopali tudi avtoritativno z besedami $\gg$ tako boste delali«.

Skupina C I ni predstavila svojih stilov vodenja, temveč je opisala svoje videnje potrebnih pristopov $\mathrm{k}$ vodenju sprememb. Vodjo sprememb je opisala kot osebo, ki je sposobna povezovati ljudi. Ima neko moč v organizaciji, s katero doseže, da ji ljudje sledijo. Mora imeti dobro razvite komunikacijske veščine. Nekateri vodje v skupini $\mathrm{C}_{2}$ uporabljajo participativni stil vodenja. Svoje sodelavce povprašajo za nasvet in jih vključujejo v odločanje. Največkrat dosežejo skupen dogovor, ki se ga vsi držijo. Drugi vodja v skupini $\mathrm{C}_{2}$ je dejal, da preveč demokracije ne vodi nikamor. Eni so vedno za, drugi pa proti. Kot vodja se mora odločiti sam in za odločitev sprejeti odgovornost, kar je presenetljivo skladno tudi z ugotovitvami nekaterih avtorjev (Pardo del Val, Martinez-Fuentes in Roig-Dobon 2012, I85I).

Stil vodenja, ki ga uporablja vodstvo bolnišnice D, je na prvi pogled avtokratski. Kot so povedali, je to v glavnem zaradi skrbi glede napak. Vodstvu v tej bolnišnici podaljševanje delovnika ni težko, tudi opravljanje nalog izven njihovega delokroga ne. Skupina vodij D2 je kot ključno predstavila vključenost izvajalcev, ki jih povabijo $\mathrm{k}$ razmišljanju in vključujejo v odločanje, kar zopet kaže na participativni način vodenja. Vodenje sprememb je ena izmed vodij opisala na naslednji način:

Meni se je zdelo zelo težko. Govorim iz lastnih izkušenj, ker mi je pomembno, da lahko pridobim ljudi, da delajo več, kot je treba. Zgodi se, da mi kakšen reče, da ne bo delal niti pet minut dlje, spet drugi pa lahko naredi dvesto ur več. Načeloma sem navajena, da se stvari odvijajo hitreje. Sem v 
dvojni vlogi, po eni strani moram skrbeti za 250 ljudi, po drugi strani pa varčevati. In če imajo ljudje tisoče opravljenih urv dobro, potem nisi uspešen. Če si osebnostno naravnan na red in organizacijo, je to zelo zahtevno delo.

Njena izčrpna pripoved kaže na dejstvo, da je management v zdravstvu vpet med različne pritiske, kar ugotavlja tudi Goodwin $(2006,66)$.

Skupina Eı prisega na mehki način vodenja, kar pa ne pomeni, da do zaposlenih nimajo zahtev in pričakovanj. Z njimi veliko komunicirajo in $\mathrm{z}$ argumenti povedo, kaj je njihovo delo. Vključujejo jih v določanje ciljev. Zanimivo je, da so edina skupina, ki je izpostavila čustveno inteligenco pri vodenju. Direktor je svoj pristop takole opisal:

Zdravstvo je specifična zgodba. Uporabljam mehki način vodenja. Veliko se pogovarjam z ljudmi in pričakujem, da se bodo vključevali v cilje. Seveda tudi pridem in rečem - to boš naredil pa konec. V glavnem pa menim, da je treba ljudem razložiti, zakaj naj nekaj naredijo. Čustvena inteligenca ne dopušča avtoritativnega načina vodenja. Če spremljate indekse uspešnosti, takoj vidite, katera podjetja v vodenje vključujejo tudi čustveno inteligenco.

Vodje E2 so povedali, da se v bolnišnici izogibajo avtoritativnemu stilu vodenja, ker z njim zaposlenim ne bi dovolili lastnega razmišljanja, temveč bi vsiljevali svojega. Pri odgovorih glede načinov in stilov vodenja so bile vse skupine bolj skope. Nekatere so se odgovoru celo izognile, kar kaže na dejstvo, da o tem neradi govorijo. Menimo, da so razlogi v ne dovolj dobrem poznavanju področja, saj se je pri večini skupin izkazalo, da še niso slišale za transformacijsko ali transakcijsko vodenje. Ločili so med demokratičnim in avtoritativnim vodenjem, značilnosti participativnega pa so znali opisati, ne da bi vedeli za njegovo poimenovanje. Pozitivno nas je presenetil direktor v bolnišnici E, ki je zase menil, da v svoje vodenje vključuje čustvenointeligenčne dejavnike.

\section{Ključni elementi vodenja v procesib spreminjanja}

Intervjuvance smo spraševali, kaj so po njihovem mnenju ključni elementi vodenja v procesih spreminjanja. Vsi intervjuvanci so ključne elemente vodenja videli predvsem v osebnostnih lastnostih vodje in ostalih potrebnih kompetencah za vodenje. Njihove odgovore smo združili v štiri sklope:

- osebne lastnosti: moralen, etičen, pošten, vztrajen, pravičen, odkrit, zanesljiv, optimističen, pozitiven, potrpežljiv, karizmatičen; 
- komunikacijske kompetence: sposobnost reševanja konfliktov, prepričljivost, dober poslušalec;

- medosebne kompetence: spoštljiv do sodelavcev, odprt in dostopen, podporen, razvit socialni čut, razumevajoč, dober motivator, se zavzame za svoje ljudi, upošteva mnenja drugih, diplomatski, dober zgled;

- strokovne in organizacijske kompetence: dober načrtovalec sprememb, strokovnjak na svojem področju, strateg, sistematičen, organizator.

Nekatere lastnosti, ki so jih izpostavili v bolnišnicah, se skladajo z ugotovitvami avtorja raziskave o lastnostih in značilnostih kliničnih vodij Stanleyja $(2006,27)$ in smo jih predstavili v enem izmed prejšnjih poglavij. Ti značilnosti sta dostopnost in klinična kompetentnost, ki so jo naši intervjuvanci poimenovali kot »biti strokovnjak na svojem področju«. Skupni sta še dve kompetenci, in sicer, da mora biti vodja dober motivator in podpirajoč. Tudi Larkin $(2015,26)$ ugotavlja, da je klinična kompetentnost zelo pomembna kompetenca vršnih zdravstvenih managerjev.

Intervjuvanci so na prvo mesto postavili komunikacijo. V svojih odgovorih jo je navedlo kar devet skupin. Pri tem niso imeli v mislih enostranskega informiranja, temveč dvostransko komunikacijo, vključevanje že v samo pripravo za spremembe. Komunikacije z vrha navzdol ne sprejemajo kot primerno pri vodenju sprememb. Zaposleni so zavzetejši za novosti, če so vključeni od samega začetka in imajo možnost predstaviti svoje poglede. Na drugo mesto so postavili pomembno lastnost vodje, tj. pravičnost, izpostavilo jo je kar pet skupin. Vodjeva pravičnost se kaže v enaki obravnavi sodelavcev. Krivice bolijo in storjena krivica zagotovo ne prispeva $\mathrm{k}$ večji zavzetosti in motivaciji človeka, ki jo je bil deležen. $\mathrm{Na}$ tretje mesto pa so intervjuvanci postavili zgled oz. vodenje z zgledom. Ta vodstvena kompetenca je pomembna za tri skupine intervjuvancev. Vodja, ki ni kredibilen oz. od zaposlenih zahteva nekaj povsem drugega, kot počne sam, pri vodenju sprememb ne bo uspešen. Strokovnost, strpnost, karizmatičnost, prepričljivost in sposobnost motiviranja sodelavcev so intervjuvane skupine izpostavile v dveh primerih, vse ostalo pa enkrat.

\section{Povzročitelji sprememb v bolnišnicah}

Intervjuvanci so izpostavili, da je večina sprožilcev oz. povzročiteljev sprememb v bolnišnicah v zunanjem okolju. Skupina $\mathrm{H}_{3}$ je povedala, da je današnji bolnik zelo zahteven in razgledan. Tudi temu se morajo prilagajati, naročati ob urah ipd., kar pomeni drugačno organizacijo dela, kot 
je bila nekoč. Včasih so vsi čakali v čakalnici, pa ni bilo slabe volje. Danes ni tako.

V večini bolnišnic so povedali, da zahteve po novostih postavljajo lastniki in financer. Številne izmed teh zahtev se jim zdijo nesmiselne. Želeli smo vključiti še pogled financerja, zato smo opravili intervju s predstavnikom Zavoda za zdravstveno zavarovanje, čeprav v prvotnem načrtu raziskave to ni bilo predvideno. Zaradi časovnih omejitev nam ni uspelo vključiti še vidika Ministrstva za zdravje kot lastnika oz. regulatorja dejavnosti v zdravstvu. Na Zavodu za zdravstveno zavarovanje so povedali, da spremembe v bolnišnicah povzroćajo predvsem spremembe obračunskih modelov na njihovi strani. Če npr. financirajo $20 \%$ več operacij, morajo v bolnišnicah spremeniti oz. prilagoditi svoje procese dela, da uspejo povečano število operacij tudi realizirati. Obratno seveda ne velja. Če bolnišnica presega $s \gg$ Splošnim dogovorom « dogovorjen program, financer teh storitev ne plača. Zanimalo nas je tudi, kakšni so odpori vodstev bolnišnic ob spremembah, ki jih zahteva financer. Odgovor direktorja je bil, da več kot je administrativnega dela, večji so odpori, kar smo izvedeli tudi v bolnišnicah. Vendar pa je direktor povedal, da nekateri mislijo, da lahko prejmejo plačilo brez dokazil, kar pa ne gre. Zanimalo nas je tudi, kako so vodstva bolnišnic reagirala na zahtevo po akreditaciji. Direktor je povedal, da je to zahtevo sprožilo Ministrstvo za zdravje, vendar so jo vodstva bolnišnic presenetljivo pozitivno sprejela.

\section{Analiza, rezultati in ugotovitve kvantitativne raziskave}

Analiza rezultatov kvantitativne empirične raziskave zajema analizo posameznih konstruktov, faktorsko analizo konstruktov sprememb in uspešnosti ter regresijsko in korelacijsko analizo. $\mathrm{V}$ nadaljevanju predstavljamo vzorec $s$ frekvenčnimi predstavitvami demografskih spremenljivk.

\section{Analiza vzorca kvantitativne raziskave}

Populacijo za kvantitativno raziskavo so predstavljale slovenske bolnišnice. V Sloveniji obstaja 26 javno financiranih bolnišnic. Vzorec osmih bolnišnic je bil izbran računalniško z generiranjem naključnih števil. $\mathrm{V}$ bolnišnice smo poslali 3.000 anketnih vprašalnikov, kar je predstavljalo $54 \%$ vseh zaposlenih v teh bolnišnicah. Število vprašalnikov za posamezno bolnišnico smo določili proporcionalno glede na število zaposlenih. Znotraj bolnišnic smo uporabili kvotni vzorec, kar smo že predstavili v razdelku 6.5. Do prvotno dogovorjenega datuma je na anketo odgovorilo I 42 anketirancev, po ponovnih telefonskih pozivih pa smo prejeli še is2 
izpolnjenih vprašalnikov. Prvotno dogovorjen čas za vračanje vprašalnikov je bil I 8 dni, ki pa smo ga podaljšali še za dodatnih 6 dni.

Strukturo vzorca smo analizirali glede na značilnosti vključenih bolnišnic (splošna, specialna, terciarna), glede na značilnosti anketirancev in ocenjevanih oseb (spol, starost), glede na vlogo, ki so jo imeli anketiranci med uvajanjem sprememb in glede na njihovo vključenost $\mathrm{v}$ spremembe. V nadaljevanju predstavljamo vzorec z opisno statistiko.

Preglednici 5 in 6 prikazujeta strukturo anketirancev glede na spol ter starost.

Preglednica 5: Struktura anketirancev glede na spol

\begin{tabular}{lccccc} 
& Spol & Frekvenca & Delež $(\mathbf{v} \%)$ & Veljavni $(\mathbf{v} \%)$ & $\begin{array}{c}\text { Zbirni delež } \\
(\mathbf{v} \%)\end{array}$ \\
\cline { 2 - 6 } Veljavni & Moški & 47 & 16,0 & 16,7 & 16,7 \\
\cline { 2 - 6 } & Ženki & 234 & 79,6 & 83,3 & 100,0 \\
\cline { 2 - 6 } & Skupaj & $28 \mathrm{I}$ & 95,6 & 100 & \\
\hline Manjkajoči & 13 & 4,4 & & \\
\hline Skupaj & 294 & 100,0 & \\
\hline
\end{tabular}

I6 \% anketirancev je moškega spola, 79,6 \% pa ženskega, kar se sklada $\mathrm{z}$ odstotkom zaposlenosti moških in žensk v zdravstvu. 4,4 \% anketirancev odgovora o spolu ni dalo.

Preglednica 6: Struktura anketirancev glede na starost

\begin{tabular}{|c|c|c|c|c|c|}
\hline & Starost & Frekvenca & Delež (v \%) & Veljavni (v \%) & $\begin{array}{l}\text { Zbirni delež } \\
\quad(\mathrm{v} \%)\end{array}$ \\
\hline \multirow{6}{*}{ Veljavni } & Manj kot 30 & 39 & 13,3 & 14,2 & 14,2 \\
\hline & $3 \mathrm{I}-40$ let & $7 \mathrm{I}$ & $24, \mathrm{I}$ & 25,8 & 40,0 \\
\hline & $4 \mathrm{I}-50$ let & 95 & 32,3 & 34,5 & 74,5 \\
\hline & $5 \mathrm{I}-60$ let & 65 & $22, \mathrm{I}$ & 23,6 & 98,2 \\
\hline & Več kot 60 let & 5 & 1,7 & I,8 & 100,0 \\
\hline & Skupaj & 275 & 93,5 & 100 & \\
\hline Manjkajoči & & 19 & 6,5 & & \\
\hline Skupaj & & 294 & 100,0 & & \\
\hline
\end{tabular}


Preglednica 6 razkriva, da je največji delež anketirancev starih med $4 \mathrm{I}$ in 50 let, najmanj pa je starih več kot 60 let in mlajših od 30 let, kar je skladno s starostno strukturo $\mathrm{v}$ bolnišnicah.

Preglednica 7 prikazuje spol ocenjevanih vodij sprememb oz. vodij projektov sprememb v bolnišnicah. 19,3 odstotka vodij je bilo moškega spola, 80,7 odstotka pa ženskega.

Preglednica 7: Spol ocenjevane osebe

\begin{tabular}{cccccc} 
& \multicolumn{1}{c}{ Spol } & Frekvenca & Delež $(\mathrm{v} \%)$ & Veljavni $(\mathbf{v} \%)$ & Zbirni delež $(\mathbf{v} \%)$ \\
\cline { 2 - 5 } Veljavni & Moški & 44 & 19,3 & 19,3 & 19,3 \\
\cline { 2 - 6 } & Ženski & 184 & 80,7 & 80,7 & 100,0 \\
\cline { 2 - 6 } & Skupaj & 228 & 100,0 & 100 & \\
\hline
\end{tabular}

Najvišji delež ocenjevanih vodij je bil star med 4I in 50 let, sledili so tisti, ki so bili stari med $5 \mathrm{I}$ in 60 let. Najmanj ocenjenih vodij je bilo starih manj kot 30 ali več kot 60 let. Starost ocenjenih vodij prikazuje preglednica 8.

Preglednica 8: Starost ocenjevane osebe

\begin{tabular}{|c|c|c|c|c|c|}
\hline & Starost & Frekvenca & $\operatorname{Delež}(v \%)$ & Veljavni (v \%) & $\begin{array}{l}\text { Zbirni delež } \\
\quad(\mathbf{v} \%)\end{array}$ \\
\hline \multirow{6}{*}{ Veljavni } & Manj kot 30 & 4 & $\mathrm{I}, 8$ & I,8 & I,8 \\
\hline & $3 \mathrm{I}-40$ let & 44 & 19,7 & 19,7 & $2 \mathrm{I}, 5$ \\
\hline & $4 \mathrm{I}-50$ let & 99 & 44,4 & 44,4 & 65,9 \\
\hline & $5 \mathrm{I}-60$ let & 70 & $3 \mathrm{I}, 4$ & 31,4 & 97,3 \\
\hline & Več kot 60 let & 6 & 2,7 & 2,7 & 100,0 \\
\hline & Skupaj & 223 & 100 & 100 & \\
\hline
\end{tabular}

V vzorec so bili v največji meri vključeni sodelavci na projektu (53,I $\%$ ), sledijo vodje projekta in člani tima, odgovornega za uvedbo spremembe, ter tisti, ki so se opredelili kot drugo (17\%). Pod drugo so respondenti največkrat navedli svoj poklic (npr. srednja medicinska sestra na oddelku). Najmanj je bilo v vzorec vključenih direktorjev in pomočnikov direktorjev. Vlogo, ki so jo imeli anketiranci med uvajanjem sprememb, prikazuje preglednica 9. 
Preglednica 9: Vloga anketirancev med uvajanjem sprememb

\begin{tabular}{|c|c|c|c|c|c|}
\hline & Vloga & Frekvenca & $\operatorname{Delež~(v\% )~}$ & Veljavni (v \%) & Zbirni delež (v \%) \\
\hline \multirow{5}{*}{ Veljavni } & Direktor & 6 & 2,0 & 2,3 & 2,3 \\
\hline & $\begin{array}{l}\text { Vodja projekta } \\
\text { oz. član tima }\end{array}$ & 49 & 16,7 & I 8,8 & $2 \mathrm{I}, \mathrm{I}$ \\
\hline & Sodelavec & 156 & $53, \mathrm{I}$ & 59,8 & 80,8 \\
\hline & Drugo & 50 & 17,0 & 19,2 & 100,0 \\
\hline & Skupaj & $26 \mathrm{I}$ & 88,8 & 100 & \\
\hline Manjkajoči & & 33 & $\mathrm{II}, 2$ & & \\
\hline Skupaj & & 294 & 100,0 & & \\
\hline
\end{tabular}

Več kot polovica vključenih v vzorec je pri spremembah sodelovala pasivno, kar pomeni, da so imeli glede spremembe zelo malo ali skoraj nič neposrednih nalog oz. aktivnosti. 42,9 \% vključenih v vzorec pa je pri spremembah sodelovalo aktivno, kar pomeni, da je opravilo veliko nalog oz. aktivnosti, vezanih na spremembo. 6, I \% anketiranih ni dalo odgovora glede vključenosti. Vključenost v izvajanje sprememb prikazuje preglednica Io.

Preglednica ıo: Vključenost v izvajanje sprememb

\begin{tabular}{lccccc} 
& & Frekvenca & Delež $(\mathbf{v} \%)$ & Veljavni $(\mathbf{v} \%)$ & Zbirni delež $(\mathbf{v} \%)$ \\
\multirow{2}{*}{ Veljavni } & Aktivna & 126 & 42,9 & 45,7 & 45,7 \\
\cline { 2 - 5 } & Pasivna & 150 & 51,0 & 54,3 & 100,0 \\
\cline { 2 - 6 } & Skupaj & 276 & 93,9 & 100,0 & \\
\hline Manjkajoči & 18 & 6,1 & & \\
\hline Skupaj & 294 & 100,0 & \\
\hline
\end{tabular}

Kot je razvidno iz preglednice i i, je bilo največ respondentov zaposlenih v splošnih bolnišnicah (7 I,4 \%), najmanj pa v specialnih (4,I \%), kar je skladno s strukturo bolnišnic. $2 \%$ anketirancev nista opredelila, v katero vrsto bolnišnice sodi tista, v kateri delajo. 
Preglednica i I : Razvrstitev anketirancev glede na vrsto bolnišnice

\begin{tabular}{lccccc} 
& & Frekvenca & Delež $(\mathbf{v} \%)$ & Veljavni $(\mathbf{v} \%)$ & $\begin{array}{c}\text { Zbirni delež } \\
(\mathrm{v} \%)\end{array}$ \\
\cline { 2 - 6 } Veljavni & Splošna bolnišnica & 210 & $7 \mathrm{I}, 4$ & 72,9 & 72,9 \\
\cline { 2 - 6 } & Specialna bolnišnica & $\mathrm{I} 2$ & $4, \mathrm{I}$ & 4,2 & $77, \mathrm{I}$ \\
\cline { 2 - 6 } & Terciarna bolnišnica & 66 & 22,4 & 22,9 & 100,0 \\
\cline { 2 - 6 } & Skupaj & 288 & 98 & & \\
\hline Manjkajoči & 6 & 2 & & \\
\hline Skupaj & 294 & 100,0 & & \\
\hline
\end{tabular}

\section{Analiza komponent posameznib konstruktov}

Kot smo zapisali v uvodnem delu pričujoče monografije, je bilo oblikovanje nove merske lestvice za merjenje vrst sprememb v bolnišnicah ključen metodološki prispevek raziskave. $S$ kvalitativno analizo in teoretičnimi spoznanji o vrstah sprememb smo identificirali značilnosti sprememb in določili 20 indikatorjev za merjenje vrst sprememb, pri čemer smo vsako vrsto spremenljivk opredelili s petimi značilnostmi. To je bil prvi koncept, ki so ga anketiranci ocenjevali na petstopenjski lestvici od I do 5 .

Predpostavljali smo, da bo prvih pet indikatorjev merilo konstrukt »inkrementalno temeljne spremembe«, drugih pet indikatorjev konstrukt »inkrementalno periferne spremembe«, naslednjih pet indikatorjev konstrukt »radikalno periferne spremembe torjev konstrukt »radikalno temeljne spremembe«. Slika 2 I prikazuje konstrukte posamezne vrste sprememb s predpostavljenimi indikatorji oz. spremenljivkami.

Preglednica I 2 prikazuje opisne statistike za posamezne indikatorje merjene spremenljivke sprememb.

Anketiranci so v povprečju ocenili spremembe, ki so jih izvajali v bolnišnicah, nad nevtralno vrednostjo, ki znaša 2,5. Najvišje povprečje $(3,63)$ ima spremenljivka 3 , ki se nanaša na stalno (postopno) izboljševanje kakovosti (»Sprememba predstavlja manjsi korak naprej v procesu stalnega izboljševanja kakovosti zdravstvenih storitev v svojem oddelku.«). Pri tem indikatorju smo pričakovali visoko ocenjeno vrednost, saj je v vseh bolnišnicah velik poudarek na kakovosti, kar so pokazali tudi rezultati kvalitativne raziskave, $\mathrm{v}$ kateri smo ugotovili, da so vse bolnišnice akreditirane in/ali imajo vpeljan ISO-standard. 


\begin{tabular}{|c|c|c|c|c|}
\hline & & Konstrukti IT-, IP-, & $\mathbf{R P}$ - in RT-sprememb & \\
\hline & $\begin{array}{l}\text { Predpostavljene } \\
\text { spremenljivke } \\
\text { konstrukta } \\
\text { IT-spremembe }\end{array}$ & $\begin{array}{c}\text { Predpostavljene } \\
\text { spremenljivke } \\
\text { konstrukta } \\
\text { IP-spremembe }\end{array}$ & $\begin{array}{c}\text { Predpostavljene } \\
\text { spremenljivke } \\
\text { konstrukta } \\
\text { RP-spremembe }\end{array}$ & $\begin{array}{c}\text { Predpostavljene } \\
\text { spremenljivke } \\
\text { konstrukta } \\
\text { RT-spremembe }\end{array}$ \\
\hline S1 & $\begin{array}{l}\text { Spremenili smo metodo } \\
\text { zdravljenja ali } \\
\text { diagnosticiranja, kar pa } \\
\text { za naš oddelek ne } \\
\text { predstavlja bistvene } \\
\text { razlike. } \\
\text { Uvedli smo nov } \\
\text { zdravstveni program oz. } \\
\text { dejavnost, kar pa ni } \\
\text { predstavljalo izrazitih } \\
\text { pretresov ali motenj v } \\
\text { našem oddelku. } \\
\text { Sprememba predstavlja } \\
\text { manjši korak naprej v } \\
\text { procesu stalnega } \\
\text { izboljšsvanja kakovosti } \\
\text { zdravstvenih storitev v } \\
\text { našem oddelku. } \\
\text { Postopoma smo } \\
\text { optimizirali organizacijo } \\
\text { dela v temeljnih } \\
\text { dejavnostih našega } \\
\text { oddelka ali bolnišnice. } \\
\text { Postopoma smo } \\
\text { spremenili metode dela v } \\
\text { okviru temeljnih } \\
\text { dejavnosti svojega } \\
\text { oddelka. }\end{array}$ & $\begin{array}{l}\text { S6 Spremenili smo postopke } \\
\text { dela, vezane na podporne } \\
\text { dejavnosti, pri čemer je } \\
\text { sprememba pomenila } \\
\text { logično nadaljevanje iz } \\
\text { prejšnjega stanja v novo } \\
\text { stanje. } \\
\text { S7 Sprememba predstavlja } \\
\text { manjši korak naprej pri } \\
\text { stalnem izboljševanju } \\
\text { podpornih dejavnosti } \\
\text { svojega oddelka. } \\
\text { S8 Postopoma smo } \\
\text { optimizirali procese dela } \\
\text { v podpornih dejavnostih. } \\
\text { S9 Spremenili smo } \\
\text { administrativne postopke. } \\
\text { S10 Sprememba se je } \\
\text { nanašala na nadgradnjo } \\
\text { obstoječega } \\
\text { informacijskega sistema. }\end{array}$ & $\begin{array}{l}\text { S11 V podporni(h) } \\
\text { dejavnosti(h) smo } \\
\text { uvedli spremembo, ki je } \\
\text { bila pomembna in nujna } \\
\text { za naš oddelek. } \\
\text { S12 Korenito smo } \\
\text { spremenili procese dela } \\
\text { v podporni(h) } \\
\text { dejavnosti(h). } \\
\text { S13 V podporni(h) } \\
\text { dejavnosti(h) smo uvedli } \\
\text { nov tehnološki postopek } \\
\text { ali novo metodo dela. } \\
\text { S14 Uvedli smo nov } \\
\text { informacijski sistem. } \\
\text { S15 Uvedli smo novo } \\
\text { podporno dejavnost. }\end{array}$ & $\begin{array}{l}\text { S16 Popolnoma smo } \\
\text { reorganizirali oddelke, ki } \\
\text { opravljajo našo temeljno } \\
\text { dejavnost. } \\
\text { S17 Spremenili smo temeljni } \\
\text { program svojega oddelka } \\
\text { ali bolnišnice, kar je } \\
\text { bistveno vplivalo na naš } \\
\text { utečen način dela. } \\
\text { S18Korenito smo spremenili } \\
\text { načine dela v temeljnih } \\
\text { procesih. } \\
\text { S19 Uvedli smo novo } \\
\text { temeljno dejavnost } \\
\text { oddelka, ki predstavlja } \\
\text { prelom s starim oz. } \\
\text { prekinitev stare } \\
\text { dejavnosti. } \\
\text { S20 Uvedli smo novo } \\
\text { temeljno dejavnost } \\
\text { bolnišnice. }\end{array}$ \\
\hline
\end{tabular}

Slika 2 I: Konstrukti vrste sprememb s predpostavljenimi indikatorji

Preglednica I2: Opisne statistike za posamezne indikatorje merjene spremenljivke sprememb

Spremenili smo metodo zdravljenja ali diagnosticiranja, kar pa za naš oddelek ne predstavlja bistvene razlike.

$222 \quad 2,84 \quad \mathrm{I}, 204$

Uvedli smo nov zdravstveni program oz. dejavnost, kar pa ni predstavljalo izrazitih pretresov ali motenj v našem oddelku.

$222 \quad 2,97 \quad 1,184$

Sprememba predstavlja manjši korak naprej v procesu stalnega izboljševanja kakovosti zdravstvenih storitev v našem oddelku.

$222 \quad 3,63 \quad 0,997$




\section{Vprašanje}

Postopoma smo optimizirali organizacijo dela v temeljnih dejavnostih našega oddelka ali bolnišnice.

222

3,50

0,978

Postopoma smo spremenili metode dela v okviru temeljnih dejavnosti svojega oddelka.

222

$3,4 \mathrm{I}$

1,063
Spremenili smo postopke dela, vezane na podporne dejavnosti, pri čemer je sprememba pomenila logično nadaljevanje iz prejšnjega stan222 ja v novo stanje.

Sprememba predstavlja manjši korak naprej pri stalnem izboljševanju podpornih dejavnosti svojega oddelka.

Postopoma smo optimizirali procese dela v podpornih dejavnostih.

Sprememba se je nanašala na nadgradnjo obstoječega informacijskega sistema.

222

3,28

I,O79

V podporni(h) dejavnosti(h) smo uvedli spremembo, ki je bila pomembna in nujna za naš oddelek.

Korenito smo spremenili procese dela v podporni(h) dejavnosti(h).

V podporni(h) dejavnosti(h) smo uvedli nov tehnološki postopek ali novo metodo dela.

222

2,97

1,055

Uvedli smo nov informacijski sistem.

222

2,73

$\mathrm{I}, \mathrm{I} 7 \mathrm{5}$

Uvedli smo novo podporno dejavnost.

222

2,69

$\mathrm{I}, \mathrm{IOO}$

Popolnoma smo reorganizirali oddelke, ki opravljajo našo temeljno dejavnost.

Spremenili smo temeljni program svojega oddelka ali bolnišnice, kar je bistveno vplivalo na naš utečen način dela.

222

2,72

$\mathrm{I}, 078$

Korenito smo spremenili načine dela v temeljnih procesih.

Uvedli smo novo temeljno dejavnost oddelka, ki predstavlja prelom s starim oz. prekinitev stare dejavnosti. 
Druga najbolje ocenjena sprememba je sprememba 4 , ki se nanaša na postopno optimiziranje organizacije dela (»Postopoma smo optimizirali organizacijo dela $v$ temeljnih dejavnostih svojega oddelka ali bolnišnice.«). Nadpovprečna vrednost tega indikatorja je bila prav tako pričakovana, saj so jo nakazovali izsledki predhodne kvalitativne raziskave. Tretja najbolje ocenjena spremenljivka je bila sprememba 7 (»Sprememba predstavlja manjši korak naprej pri stalnem izboljševanju podpornih dejavnosti svojega oddelka.«). Spremembe, s katerimi so se anketiranci najbolj strinjali, spadajo v kategorijo postopnih (inkrementalnih) oz. kontinuiranih sprememb, kar pomeni, da so $\mathrm{v}$ preučevanih bolnišnicah v preteklem letu inkrementalne spremembe izvajali pogosteje kot radikalne.

$\mathrm{V}$ povprečju so se anketiranci najmanj strinjali s spremenljivko I9 (»Uvedli smo novo temeljno dejavnost oddelka, ki predstavlja prelom s starim oz. prekinitev stare dejavnosti.«). Tudi ta rezultat je bil pričakovan. Spremenljivka se navezuje na radikalne spremembe, za katere pa sov nekaterih bolnišnicah povedali, da jih sploh niso izvajali. Radikalne spremembe pomenijo dramatične izboljšave »kritičnih« področij delovanja bolnišnice. Mnogi avtorji (Burke 2002, 65; Griffith-Cooper in King 2007, I6) jih enačijo z organizacijsko transformacijo, pri kateri gre za ostre in simultane premike v strategiji, porazdelitvi organizacijske moči, strukturi in kontrolnih mehanizmih bolnišnice (McNulty in Ferlie 2004, 1391), kar pa se v bolnišnicah redkeje pojavlja kot pa stalno uvajanje inkrementalnih sprememb.

Iz povprečij je razvidno, da so se gibala med 2,6 in 3,6, kar pomeni, da so v povprečju izvajali vse vrste sprememb. Iz standardnih odklonov lahko razberemo, da so na trditve anketiranci odgovarjali precej homogeno.

$\mathrm{V}$ naslednjem sklopu vprašanj so anketiranci ocenjevali uspešnost uvedenih sprememb, ki smo jo merili s štirimi indikatorji.

Preglednica 1 3: Opisne statistike za merjene indikatorje spremenljivke uspešnost

\begin{tabular}{lccc}
\multicolumn{1}{c}{ Vprašanje } & N & Povprečje & St. odklon \\
\hline Spremembo smo uvedliv začrtanih rokih. & 272 & 3,34 & $\mathrm{I}, 040$ \\
\hline Spremembo smo uvedliv okviru načrtovanih stroškov. & 272 & 3,34 & 1,000 \\
\hline Namen spremembe je bil dosežen. & 272 & 3,56 & 0,939 \\
\hline Dosegli smo začrtane cilje v povezavi s spremembo. & 272 & 3,54 & 0,892 \\
\hline
\end{tabular}

Iz preglednice $\mathrm{s} 3$ je razvidno, da so spremembe v povprečju ocenjevali kot uspešne. Anketiranci so kot najuspešnejše ocenili doseganje name- 
na in ciljev spremembe. Za malenkost niže pa so ocenili doseganje rokov in načrtovanih stroškov.

V tretjem sklopu vprašanj so anketiranci ocenjevali vedenja vodij projektov sprememb oz. oseb, ki so vodile izvajanje najznačilnejših sprememb. Stile vodenja smo merili na osnovi že mnogokrat preverjenega in validiranega vprašalnika MLQ - 5 X, ki ga v delu za ocenjevanje stilov vodenja sestavlja 36 trditev, ki oblikujejo 9 komponent TF-, TS- in LF-vodenja.

Konstrukt transformacijsko vodenje (TF-vodenje) sestavlja 20 indikatorjev, konstrukt transakcijsko vodenje (TS-vodenje) I 2 indikatorjev in konstrukt vodenje laissez-faire (LF-vodenje) 4 indikatorji. Ker gre za standardiziran vprašalnik, faktorske analize nismo delali. Oblikovanje posameznih faktorjev glavnih stilov vodenja smo prevzeli po navodilih avtorjev Priročnika za uporabo MLQvprašalnika (Walumbwa in Zhu 2004). Avtorja (prav tam, I3-15) sta navedla, da je bil vprašalnik v zadnjih 25 letih uporabljen v več kot $\mathrm{r} .000$ različnih vrstah organizacij, kot so: vojska, vladne organizacije, izobraževanje, gospodarstvo, bolnišnice, prostovoljske organizacije idr., tako v ZDA kot drugje po svetu na velikih vzorcih (več kot I.000). Izsledki mnogih raziskav so nakazovali 9-faktorski model.

Konstrukt LF-vodenje predstavlja samostojen faktor, v katerega so vključene spremenljivke 5, 7, 28 in 33. Kot smo že povedali, vseh trditev v vprašalniku ne razkrivamo zaradi zahtev avtorjev. Vprašalnik je avtorska last podjetja Mind Garden, ki ne dovoljuje celotnega razkritja. Vseeno pa številčno predstavljamo, katere spremenljivke sodijo v posamezni faktor. Prvi dve spremenljivki oz. posameznega indikatorja se glasita:

(s) Oseba, ki jo ocenjujem, se je izogibala reševanju pomembnih vprašanj, ki so se pojavila.

(7) Oseba, ki jo ocenjujem, je bila odsotna, kadar sem jo potrebo$\operatorname{val}(-a)$.

(28) Indikatorja ne razkrivamo.

(33) Indikatorja ne razkrivamo.

Konstrukt TS-vodenje oblikujejo 3 faktorji: management $\mathrm{z}$ izjemami - pasivni (spremenljivke 3, I2, 17 in 20), management z izjemami - aktivni (spremenljivke 4, 22, 24, 27) ter pogojevano nagrajevanje (spremenljivke I, I I, I6 in 35). Od vsake dimenzije konstrukta TS-vodenje prikazujemo po 2 spremenljivki oz. indikatorja:

(3) Oseba, ki jo ocenjujem, ni ukrepala, dokler problemi niso postali resni. 
(I2) Oseba, ki jo ocenjujem, je počakala, da so šle stvari narobe in šele nato ukrepala.

(I7)Indikatorja ne razkrivamo.

(20) Indikatorja ne razkrivamo.

(4) Oseba, ki jo ocenjujem, je bila pozorna na nepravilnosti, napake, izjeme in odstopanja od njenih navodil oz. sprejetih standardov.

(22) Oseba, ki jo ocenjujem, se je ukvarjala predvsem z obravnavanjem napak, pritožb in neuspehov.

(24) Indikatorja ne razkrivamo.

(27) Indikatorja ne razkrivamo.

(I) Oseba, ki jo ocenjujem, mi je nudila podporo v zameno za moj trud.

( I I) Oseba, ki jo ocenjujem, je kazala zadovoljstvo, kadar sem izpolnil(-a) pričakovanja.

(I6) Indikatorja ne razkrivamo.

(35) Indikatorja ne razkrivamo.

Konstrukt TF-vodenje oblikuje 5 faktorjev: intelektualna stimulacija (spremenljivke 2, 8, 30 in 32), vpliv - vedenje (spremenljivke 6, 14, 23 in 34 ), vpliv - pripisan (spremenljivke Io, I8, 2 I in 25), inspiracijska motivacija (spremenljivke 9, I3, I6 in 26) ter individualna obravnava (spremenljivke I5, 19, 29 in 31). Zopet razkrivamo po dva indikatorja oz. spremenljivki vsake dimenzije transformacijskega vodenja:

(2) Oseba, ki jo ocenjujem, je preučila kritične predpostavke, da je preverila, ali so primerne.

(8) Oseba, ki jo ocenjujem, je iskala različne možnosti za rešitev problema.

(30) Indikatorja ne razkrivamo.

(32) Indikatorja ne razkrivamo.

(6) Oseba, ki jo ocenjujem, je govorila o svojih najpomembnejših vrednotah in prepričanjih.

(I 4)Oseba, ki jo ocenjujem, je podrobno razložila, kako pomembni so jasni cilji.

(23) Indikatorja ne razkrivamo.

(34) Indikatorja ne razkrivamo.

(ı) Oseba, ki jo ocenjujem, mi je vlivala ponos, ker sem sodeloval(-a) z njo. 
(I 8) Oseba, ki jo ocenjujem, je bila za dobro skupine pripravljena zanemariti lastne interese.

(2 I) Indikatorja ne razkrivamo.

(25) Indikatorja ne razkrivamo.

(9) Oseba, ki jo ocenjujem, je bila optimistična glede prihodnosti.

(13) Oseba, ki jo ocenjujem, je z navdušenjem govorila o ciljih, ki jih je (bilo) potrebno doseči.

(i6) Indikatorja ne razkrivamo.

(26) Indikatorja ne razkrivamo.

(I 5 ) Oseba, ki jo ocenjujem, se je posvečala poučevanju, usmerjanju in mentorstvu zaposlenim.

(19) Oseba, ki jo ocenjujem, me je obravnavala kot posameznika in ne samo kot člana skupine.

(29) Indikatorja ne razkrivamo.

(3i) Indikatorja ne razkrivamo.

Preverjali smo zanesljivost faktorjev, ki jo v nadaljevanju predstavljamo v samostojnem poglavju o zanesljivosti faktorjev.

$\mathrm{V}$ četrtem sklopu so vodje projektov oz. sprememb lahko ocenjevali sami sebe. Ena izmed prednosti vprašalnika je ravno v tem, da vprašalnik omogoča 360-stopinjsko ocenjevanje vedenj vodij. Vprašanja iz tretjega sklopa so se tu ponovila, le da so bila postavljena v prvi osebi. Sledili smo enaki postavitvi konstruktov. Sedemnajst anketirancev, ki so nastopali v vlogi člana tima odgovornega za uvedbo spremembe, je vprašalnik izpolnilo zase (samoocena) in za vodjo projekta spremembe. Pri analizi smo pri teh anketirancih upoštevali obe oceni za določanje stila vodenja.

\section{Faktorska analiza merjenih spremenljivk}

Po opravljeni osnovni statistični analizi preučevanih spremenljivk smo izvedli še faktorsko analizo in preverili konsistentnost uporabljenega merskega instrumenta. $S$ faktorsko analizo skušamo pojasniti povezave večjega števila spremenljivk $\mathrm{z}$ manjšim številom faktorjev. Ugotavljamo odnose med spremenljivkami in iščemo skupine spremenljivk, ki so med sabo najmočneje povezane. Če obstaja med njimi visoka stopnja korelacije, potem predvidevamo, da nanje vpliva nek skupen dejavnik oz. faktor. Faktorska analiza je metoda, ki se najpogosteje uporablja pri razvijanju instrumentov merjenja posameznih konstruktov.

$\mathrm{V}$ prvo faktorsko analizo smo vključili indikatorje konstrukta spremembe. V nadaljevanju smo s KMO- (Kaiser-Meyer-Olkin) in Bartletto- 
vim testom sferičnosti ugotavljali, ali so podatki primerni za faktorsko analizo.

Preglednica I4: KMO- in Bartlettov test sferičnosti za spremembe

\begin{tabular}{|c|c|c|}
\hline \multirow{3}{*}{ Bartlett's Test of Sphericity } & Approx. Chi-Square & 2240,790 \\
\hline & df & 190 \\
\hline & Sig. & 0,000 \\
\hline
\end{tabular}

Iz preglednice I 4 razberemo, da je vrednost $\mathrm{KMO}$-testa nad o,7, kar pomeni, da je vzorec dovolj kompakten, prav tako so rezultati Bartlettovega testa sferičnosti statistično pomembni $(\mathrm{p}<0,05)$, kar pomeni, da med spremenljivkami obstajajo zadovoljive korelacije. Na podlagi ugotovljenega lahko nadaljujemo s faktorsko analizo.

\section{Faktorska analiza konstrukta spremembe}

$\mathrm{Na} 20$ spremenljivkah smo opravili eksplanatorno faktorsko analizo, in sicer z metodo glavnih osi (Principal Axis Factoring). Omenjena faktorska analiza je primerna, ker so spremenljivke nastale s kvalitativno analizo in je bilo treba preučiti, v kateri faktor sodijo posamezne spremenljivke.

Faktorski model smo ocenjevali v dveh korakih. Najprej smo ocenili komunalitete $\mathrm{z}$ metodo glavnih osi in nadaljevali $\mathrm{z}$ oceno faktorskih uteži s Promaxovo poševno-kotno rotacijo. Ocene komunalitet za spremembe prikazuje preglednica is. Na podlagi komunalitet lahko ugotovimo, koliko variance posamezne spremenljivke pojasni kombinacija vseh izbranih faktorjev. Vrednosti so visoke (v povprečju nad 0,548), najnižjo komunaliteto ima spremenljivka $S_{9}$ (spremenili smo administrativne postop$k e$ ), in sicer 0,359, kar pomeni, da le 35,9 \% variabilnosti pri spremembah administrativnih postopkov lahko pojasnimo s štirimi predpostavljenimi skupnimi faktorji. Rezultati postopka z metodo glavnih osi (Principal Axis Factoring) kažejo, da je model smiselno oceniti s štirimi faktorji. 


\begin{tabular}{|c|c|c|}
\hline & Initial & Extraction \\
\hline Sprememba $S_{I}$ & 0,402 & 0,450 \\
\hline Sprememba $S_{2}$ & 0,445 & 0,463 \\
\hline$S_{\text {prememba }} S_{3}$ & 0,443 & 0,440 \\
\hline Sprememba $_{4}$ & 0,547 & 0,487 \\
\hline Sprememba $_{5}$ & 0,598 & 0,562 \\
\hline Sprememba S6 & 0,571 & 0,549 \\
\hline Sprememba $S_{7}$ & 0,549 & 0,582 \\
\hline Sprememba S8 & 0,568 & 0,532 \\
\hline Sprememba $_{9}$ & 0,418 & 0,359 \\
\hline Sprememba Sio & 0,467 & 0,416 \\
\hline Sprememba $S_{I I}$ & 0,531 & 0,490 \\
\hline Sprememba $S_{12}$ & 0,599 & 0,530 \\
\hline Sprememba $S_{13}$ & 0,555 & 0,589 \\
\hline Sprememba S ${ }_{14}$ & 0,576 & 0,574 \\
\hline Sprememba Sis & 0,617 & 0,691 \\
\hline Sprememba S16 & 0,560 & 0,567 \\
\hline Sprememba $\mathrm{S}_{17}$ & 0,682 & 0,791 \\
\hline Sprememba $S_{1} 8$ & 0,694 & 0,728 \\
\hline Sprememba $S_{19}$ & 0,616 & 0,636 \\
\hline Sprememba $S_{20}$ & 0,554 & 0,531 \\
\hline
\end{tabular}

Preglednica I 6 prikazuje vrednosti pojasnjene variance glede na posamezno število obdržanih faktorjev.

Vsi štirje faktorji skupaj pojasnijo 63,6 \% celotne variance oz. razpršenosti sprememb, po rotaciji pa 54,8 \% celotne variance. Glede na Kaiser-Guttmanov kriterij bi obdržali 4 faktorje, saj pri njih lastna vrednost (eigenvalue) presega vrednost I. Kolenski diagram na sliki 22 prikazuje lastne vrednosti faktorjev. Na podlagi Catellovega kriterija bi prav tako obdržali 4 faktorje, saj je točka preloma med 4. in 5. faktorjem največja. 
Preglednica i6: Celotna pojasnjena varianca za spremembe

\begin{tabular}{|c|c|c|c|c|c|c|c|}
\hline \multirow[b]{2}{*}{ faktor } & \multicolumn{3}{|c|}{ Začetne lastne vrednosti } & \multicolumn{3}{|c|}{$\begin{array}{c}\text { Pridobljen seštevek kvadratov faktor- } \\
\text { skih uteži }\end{array}$} & \multirow{2}{*}{$\begin{array}{c}\begin{array}{c}\text { Rotiran } \\
\text { seštevek }\end{array} \\
\text { kvadratov } \\
\text { faktorskih } \\
\text { uteži }\end{array}$} \\
\hline & skupaj & varianca $\%$ & kumulativa \% & skupaj & varianca $\%$ & kumulativa \% & \\
\hline 1 & 6,156 & 30,779 & 30,779 & 5,726 & 28,629 & 28,629 & 4,218 \\
\hline 2 & 3,278 & 16,392 & 47,171 & 2,858 & 14,289 & 42,918 & 3,994 \\
\hline 3 & 2,091 & 10,454 & 57,625 & 1,598 & 7,988 & 50,906 & 3,072 \\
\hline 4 & 1,202 & 6, OII & 63,636 & 0,785 & 3,923 & 54,829 & 3,891 \\
\hline 5 & 0,905 & 4,523 & 68,159 & & & & \\
\hline 6 & 0,810 & 4,050 & 72,209 & & & & \\
\hline 7 & 0,725 & 3,627 & 75,836 & & & & \\
\hline 8 & 0,650 & 3,249 & 79,084 & & & & \\
\hline 9 & $0,55 \mathrm{I}$ & 2,756 & $8 \mathrm{I}, 840$ & & & & \\
\hline IO & 0,533 & 2,663 & 84,503 & & & & \\
\hline II & 0,503 & 2,513 & 87,017 & & & & \\
\hline 12 & 0,398 & I,992 & 89,009 & & & & \\
\hline 13 & 0,371 & 1,856 & 90,865 & & & & \\
\hline I4 & 0,332 & 1,659 & 92,524 & & & & \\
\hline 15 & 0,311 & 1,554 & 94,078 & & & & \\
\hline 16 & 0,293 & $\mathrm{I}, 464$ & 95,542 & & & & \\
\hline 17 & 0,250 & 1,250 & 96,792 & & & & \\
\hline I8 & 0,249 & 1,247 & 98,039 & & & & \\
\hline 19 & 0,201 & 1,006 & 99,045 & & & & \\
\hline 20 & 0,191 & 0,955 & 100,000 & & & & \\
\hline
\end{tabular}

Za določanje nasičenosti faktorjev (faktorske uteži) smo uporabili Promaxovo poševno-kotno rotacijo, saj faktorji med seboj korelirajo, zato smo z uporabo te rotacije izboljšali njihovo interpretabilnost. Na podlagi prejšnjih rezultatov in velikosti nasičenosti smo se odločili obdržati 4 faktorje in vse spremenljivke $\left(S_{I}-S_{2} 0\right)$, ki smo jih zajeli v analizi. Glede na nasičenost spremenljivke $\mathrm{I}, 2,3,4$ in 5 sodijo $\mathrm{v}$ faktor $\mathrm{I}$, ki smo ga poimenovali inkrementalno temeljne (IT) spremembe. V faktor 2 sodijo spremenljivke 6, 7, 8, 9, Io in I I. Poimenovali smo ga inkrementalno periferne 
(IP) spremembe. V 3. faktor sodijo spremenljivke $\mathrm{I}_{2}, \mathrm{I}_{3}, \mathrm{I}_{4}$ in $\mathrm{I} 5$ in smo ga poimenovali radikalno periferne (RP) spremembe. $V 4$. faktor sodijo spremenljivke $16,17,18,19$ in 20 in smo ga poimenovali radikalno temeljne (RT) spremembe.

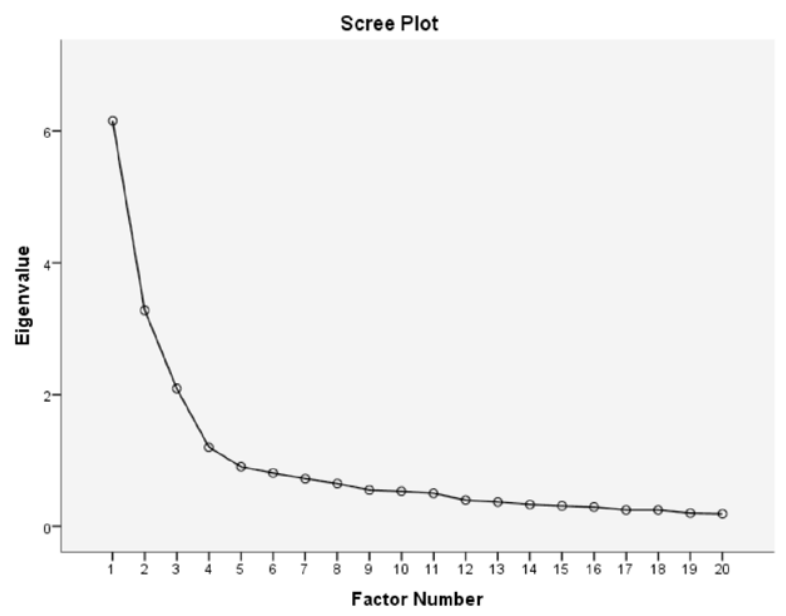

Slika 22: Kolenski diagram

Nove faktorje smo ustvarili tako, da smo sešteli vse spremenljivke, ki sodijo v posamezen faktor, in jih delili s številom vseh indikatorjev v faktorju. Na ta način smo dobili povprečne vrednosti posameznega faktorja.

Preglednica 17: Faktorske uteži za merjene spremenljivke sprememb

Spremenili smo metodo zdravljenja ali diagnosticiranja, kar pa za naš oddelek ne predstavlja bistvene razlike.

Uvedli smo nov zdravstveni program oz. dejavnost, kar pa ni predstavljalo izrazitih pretresov ali motenj v svojem oddelku.

0,702

Sprememba predstavlja manjši korak naprej v procesu stalnega izboljševanja kakovosti zdravstvenih storitev našem oddelku.

Postopoma smo optimizirali organizacijo dela v temeljnih dejavnostih našega oddelka ali bolnišnice. 
Spremenili smo postopke dela, vezane na podporne dejavnosti, pri čemer je sprememba pomenila logično nadaljevanje iz prejšnjega stanja v novo stanje.

Sprememba predstavlja manjši korak naprej pri stalnem izboljševanju podpornih dejavnosti našega oddelka.

\section{Faktorska analiza konstrukta uspešnost}

Indikatorji konstrukta uspešnost so bili vključeni v drugo faktorsko analizo. S KMO- in Bartlettovim testom smo preverjali zadovoljivost korelacij med spremenljivkami. Preglednica I 8 kaže, da je vrednost KMO-testa 
nad 0,7 , rezultati Bartlettovega testa sferičnosti pa statistično pomembni $(\mathrm{p}<0,05)$, kar kaže na zadovoljive korelacije med spremenljivkami. $\mathrm{Na}$ podlagi rezultatov lahko $s$ faktorsko analizo nadaljujemo.

Preglednica I8: KMO- in Bartlettov test sferičnosti za uspešnost

\begin{tabular}{|c|c|c|}
\hline \multicolumn{2}{|c|}{ Kaiser-Meyer-Olkin Measure of Sampling Adequacy } & 0,755 \\
\hline \multirow{3}{*}{ Bartlett's Test of Sphericity } & Approx. Chi-Square & 605,933 \\
\hline & $\mathrm{df}$ & 6 \\
\hline & Sig. & 0,000 \\
\hline
\end{tabular}

Preglednica i9: Celotna pojasnjena varianca za uspešnost

\begin{tabular}{crrrrrr} 
& \multicolumn{3}{c}{ Začetne lastne vrednosti } & \multicolumn{2}{c}{ Pridobljen seštevek kvadratov faktorskih uteži } \\
faktor & skupaj & varianca \% & kumulativa \% & skupaj & varianca \% & kumulativa \% \\
\hline I & 2,919 & 72,975 & 72,975 & 2,576 & 64,407 & 64,407 \\
\hline 2 & 0,518 & 12,960 & 85,935 & & \\
\hline 3 & 0,380 & 9,501 & 95,436 & & \\
\hline 4 & 0,183 & 4,564 & 100,00 & & \\
\hline
\end{tabular}

Na podlagi Kaiser-Guttmanovega kriterija smo izločili I faktor, saj ima samo eden lastno vrednost nad I. S tem faktorjem pojasnimo 72,98 $\%$ celotne variance (preglednica 19). Tudi na podlagi komunalitet, ki jih prikazuje preglednica 20 , lahko razberemo, da izbran faktor pojasni nad $50 \%$ variance posamezne spremenljivke, kar je zadovoljivo.

Preglednica 20: Komunalitete za uspešnost

\begin{tabular}{lcl} 
& Initial & Extraction \\
\hline$U_{\text {spešnost } U_{1}}$ & 0,528 & 0,595 \\
\hline${\text { Uspešnost } U_{2}}$ & 0,490 & 0,504 \\
\hline${\text { Uspešnost } U_{3}}$ & 0,665 & 0,685 \\
\hline Uspešnost $U_{4}$ & 0,699 & 0,793 \\
\hline
\end{tabular}


UI Dosegli smo začrtane cilje v povezavi s spremembo.

$\mathrm{U}_{2}$ Namen spremembe je bil dosežen.

$\mathrm{U}_{3}$ Spremembo smo uvedli v začrtanih rokih. $0,77 \mathrm{I}$

Iz matrike faktorskih uteži, ki jo prikazuje preglednica 2 I, lahko razberemo, da je izbran faktor, ki smo ga poimenovali uspešnost, visoko nasičen s posameznimi spremenljivkami, kar pomeni, da je smiselno vse spremenljivke obdržati. Skupen faktor ustvarimo tako, da vrednosti posameznih spremenljivk seštejemo in delimo $s$ številom indikatorjev, da dobimo povprečno vrednost.

\section{Zanesljivost faktorjev}

Veljavnost in zanesljivost faktorjev merimo s koeficientom Cronbach alfa. Preglednica 22 prikazuje koeficiente Cronbach $\alpha$ za posamezne spremenljivke kot celote (konstrukte).

Preglednica 22: Cronbach $\alpha$ koeficient za posamezne spremenljivke kot celote

\begin{tabular}{lcc}
\multicolumn{1}{c}{ Faktor } & Cronbach $\alpha$ & Stevilo merjenih spremenljivk \\
IT-spremembe & 0,773 & 5 \\
\hline IP-spremembe & 0,825 & 6 \\
\hline RP-spremembe & 0,832 & 4 \\
\hline RT-spremembe & 0,877 & 5 \\
\hline Uspešnost & 0,873 & 4 \\
\hline Pasivno vodenje & 0,871 & 8 \\
\hline Transakcijsko vodenje & 0,826 & 8 \\
\hline Transformacijkko vodenje & 0,934 & 20 \\
\hline
\end{tabular}

Zanesljivost faktorja IT-spremembe je primerna, saj znaša več kot o,7, kar je primerno za samoocenjevalne vprašalnike. Odstranitev katere izmed spremenljivk, ki so del faktorja, ne bi povišala zanesljivosti, zato vse spremenljivke obdržimo. 
Zanesljivost faktorjev IP-spremembe, RP-spremembe, RT-spremembe in zanesljivost faktorja uspešnost je $\mathrm{v} v$ veh primerih zelo dobra, saj znaša več kot 0,8 . Odstranitev katere izmed spremenljivk ne bi povišala zanesljivosti faktorja, zato v vseh primerih vse spremenljivke obdržimo.

Tudi zanesljivost faktorja laissez-faire je zelo dobra, saj znaša o,834, kar je razvidno iz preglednice 23. Odstranitev katere izmed spremenljivk, ki so del faktorja, ne bi povišala zanesljivosti.

Preglednica 23: Koeficient Cronbach a za spremenljivko LF-vodenje

\section{Cronbach's Alpha}

0,834
N of Items

4

Zanesljivost faktorja management $\mathrm{z}$ izjemami - pasivni je primerna, saj znaša 0,736 , kar je razvidno iz preglednice 24. Izločitev katere izmed vključenih spremenljivk ne bi povišala zanesljivosti.

Preglednica 24: Koeficient Cronbach a za spremenljivko management z izjemami -pasivni

Cronbach's Alpha

0,736
N of Items

Nadaljna analiza je tudi pokazala, da bi združitev obeh faktorjev (laissez-faire in management $\mathrm{z}$ izjemami - pasivni) povečala zanesljivost na $0,87 \mathrm{I}$, zato smo omenjena faktorja združili in ju poimenovali pasivno vodenje. Koeficient Cronbach alfa za združen faktor prikazuje preglednica 22 in znaša o,871. Izločitev katere koli spremenljivke združenega faktorja bistveno ne povečuje zanesljivosti, zato smo za nadaljno analizo obdržali vseh 8 indikatorjev.

Preglednica 25: Koeficient Cronbach $\alpha$ za posamezne delne konstrukte

\begin{tabular}{lcc}
\multicolumn{1}{c}{ Faktor } & Cronbach $\alpha$ & Stevilo merjenih spremenljivk \\
\hline Pogojevano nagrajevanje & 0,821 & 4 \\
\hline Manag. zizjemami aktivni & 0,512 & 4 \\
\hline Intelektualna stimulacija & 0,837 & 4 \\
\hline Navdihovalna motivacija & 0,807 & 4 \\
\hline Individualna obravnava & 0,843 & 4 \\
\hline
\end{tabular}




\begin{tabular}{lll}
\hline Vpliv-vedenje & 0,636 & 4 \\
\hline Vpliv-pripisan & 0,660 & 4 \\
\hline
\end{tabular}

Preglednica 25 prikazuje koeficiente Cronbach alfa za posamezne delne konstrukte.

V transakcijsko vodenje smo vključili dva faktorja: pogojevano nagrajevanje in management $\mathrm{z}$ izjemami (aktivni). Zanesljivost konstrukta pogojevano nagrajevanje je o,82 I. Izločitev katere koli spremenljivke konstrukta pogojevano nagrajevanje ne poveča zanesljivosti, zato obdržimo vse indikatorje.

Zanesljivost faktorja management $\mathrm{z}$ izjemami (aktivni) je nizka in znaša 0,5 I2. Odstranitev spremenljivke 22 bi zanesljivost povišala na 0,748 , kar je sicer primerno za samoocenjevalne vprašalnike.

Skupna zanesljivost konstrukta TS-vodenje pa znaša o,826 (preglednica 22), kar je zelo dobro, zato smo se odločili, da indikatorja 22 ne izločimo iz nadaljnje analize. Prav tako so $\mathrm{z}$ vidika raziskave in postavljenih hipotez pomembni skupni konstrukti (TS-vodenje, TF-vodenje in LF-vodenje) in ne posamezni faktorji, ki te konstrukte sestavljajo.

Transformacijsko vodenje sestoji iz petih faktorjev. Zanesljivosti faktorjev intelektualna stimulacija, navdihovalna motivacija in individualna obravnava so nad vrednostjo o,8, kar predstavlja zelo dobro zanesljivost. $\mathrm{V}$ vseh treh primerih izločitev katere koli v posamezen faktor vključene spremenljivke ne bi povečala zanesljivosti merjenja tega faktorja.

Zanesljivosti faktorjev vpliv - vedenje in vpliv - pripisan sta nizki. Za prvi faktor znaša 0,636 , za drugi faktor, vpliv - pripisan, pa znaša 0,660 , kar prikazuje preglednica 25. Izločitev spremenljivke 6 iz faktorja vpliv - vedenje zanesljivost poveča na 0,756 , izločitev spremenljivke 25 iz faktorja vpliv - pripisan pa zanesljivost tega faktorja poveča na 0,735 . Zanesljivost celotnega konstrukta transformacijsko vodenje znaša 0,934 (preglednica 22), zato smo v nadaljnjo analizo vključili vseh 20 spremenljivk kot celoto.

\section{Opisne statistike posameznih konstruktov}

$\mathrm{V}$ nadaljevanju prikazujemo opisne statistike posameznih konstruktov oz. faktorjev. Preglednica 26 razkriva, da so anketiranci na faktorjih IT-spremembe in IP-spremembe v primerjavi s faktorjema RP-spremembe in RT-spremembe dosegli višje povprečje. Tudi odgovori so bili pri faktorjih IT-spremembe in IP-spremembe homogenejši (nižja vrednost standardnega odklona) v primerjavi z odgovori na faktorjih RP-spremembe 
in RT-spremembe. Preverili smo tudi normalnost porazdelitve s testom Kolmogorov-Smirnova (preglednica 27), ki je pokazal, da spremenljivke niso porazdeljene približno normalno $(\mathrm{p}<0,05)$. Prav tako smo preverili koeficienta sploščenosti in asimetričnosti, ki sta bila znotraj $\pm \mathrm{I}, \mathrm{kar}$ pomeni, da lahko domnevamo, da so faktorji porazdeljeni približno normalno, saj je test normalnosti Kolmogorov-Smirnova pri večjih vzorcih občutljivejši. Za nadaljnje analize smo tako uporabili parametrične teste.

Na podlagi analize ugotavljamo, da v bolnišnicah v večji meri izvajajo tako inkrementalno temeljne kot inkrementalno periferne spremembe, $\mathrm{v}$ manjši meri pa radikalno periferne in radikalno temeljne spremembe.

Preglednica 26 Opisne statistike za vrste sprememb

IT-spremembe

IP-spremembe

RP-spremembe

RT-spremembe

\begin{tabular}{llllll} 
& Veljavni & 277 & 285 & 284 & 278 \\
\cline { 2 - 5 } & Manjkajoči & 29 & 21 & 22 & 28 \\
\hline
\end{tabular}

\begin{tabular}{lcccc}
\hline Povprečje & 3,3410 & 3,4111 & 2,8137 & 2,6584 \\
\hline St. odklon & 0,78820 & 0,74571 & $0,9010 \mathrm{I}$ & 0,91780 \\
\hline
\end{tabular}

\begin{tabular}{lcccc}
\hline Asimetričnost & $-0,502$ & $-0,452$ & $-0,261$ & $-0,129$ \\
\hline St. napaka asimetričnosti & 0,146 & 0,144 & 0,145 & 0,146 \\
\hline Sploščenost & 0,755 & 0,224 & $-0,354$ & $-0,499$ \\
\hline St. napaka sploščenosti & 0,292 & 0,288 & 0,288 & 0,291 \\
\hline Minimum & 1,00 & 1,00 & 1,00 & 1,00 \\
\hline Maksimum & 5,00 & 5,00 & 5,00 & 5,00 \\
\hline
\end{tabular}

Preglednica 27: Test Kolmogorov-Smirnova za vrste sprememb

\begin{tabular}{lccc} 
& Statistic & df & Sig. \\
\hline IT-spremembe & 0,112 & 268 & 0,000 \\
\hline IP-spremembe & 0,108 & 268 & 0,000 \\
\hline RP-spremembe & 0,113 & 268 & 0,000 \\
\hline RT-spremembe & 0,138 & 268 & 0,000 \\
\hline
\end{tabular}


Preglednica 28: Opisne statistike za posamezne faktorje vodenja

\begin{tabular}{|c|c|c|c|c|c|c|c|c|c|}
\hline & $\begin{array}{c}\text { Pogoje- } \\
\text { va-no } \\
\text { nagra- } \\
\text { je-vanje }\end{array}$ & $\begin{array}{l}\text { Intelek- } \\
\text { tu-alna } \\
\text { stimulacija }\end{array}$ & $\begin{array}{c}\text { Man- } \\
\text { age-ment } \\
\text { z izjemami } \\
\text { (pasivni) }\end{array}$ & $\begin{array}{c}\text { Man- } \\
\text { age-ment } \\
\text { z izjemami } \\
\text { (aktivni) }\end{array}$ & $\begin{array}{l}\text { Voden- } \\
\text { je laissez- } \\
\text { faire }\end{array}$ & $\begin{array}{l}\text { Vpliv- } \\
\text { vedenje }\end{array}$ & $\begin{array}{c}\text { Navdi- } \\
\text { ho-val- } \\
\text { na moti- } \\
\text { vacija }\end{array}$ & $\begin{array}{l}\text { Vpliv- } \\
\text { pripisan }\end{array}$ & $\begin{array}{l}\text { Indivi- } \\
\text { du-alna } \\
\text { obravnava }\end{array}$ \\
\hline Veljavni & 306 & 306 & 306 & 306 & 306 & 306 & 306 & 306 & 306 \\
\hline Manjkajoči & 5 & 5 & 5 & 5 & 5 & 5 & 5 & 5 & 5 \\
\hline Povprečje & 2,8695 & 2,8472 & 1,5211 & 2,6545 & 1,2173 & 2,6577 & 2,9880 & 2,6663 & 2,6687 \\
\hline Standardni odklon & 0,85090 & 0,79987 & 0,91605 & $0,6074 \mathrm{I}$ & 0,99535 & 0,75020 & 0,77196 & 0,75149 & $0,895 \mathrm{II}$ \\
\hline Asimetričnost & $-0,624$ & $-0,55^{8}$ & 0,274 & $-0,334$ & 0,542 & $-0,383$ & $-0,8 \circ \mathrm{I}$ & $-0,3 \circ 4$ & $-0,616$ \\
\hline $\begin{array}{l}\text { Standardna napaka } \\
\text { asimetričnosti }\end{array}$ & 0,139 & 0,139 & 0,139 & 0,139 & 0,139 & 0,139 & 0,139 & 0,139 & 0,139 \\
\hline Sploščenost & $-0,217$ & $-0,079$ & $-0,661$ & $-0,004$ & $-0,688$ & 0,009 & 0,475 & $-0,365$ & 0,010 \\
\hline $\begin{array}{l}\text { Standardna napaka } \\
\text { sploščenosti }\end{array}$ & 0,278 & 0,278 & 0,278 & 0,278 & 0,278 & 0,278 & 0,278 & 0,278 & 0,278 \\
\hline Minimum & 0,00 & 0,25 & 0,00 & 0,75 & $0, \infty 0$ & 0,25 & 0,25 & 0,50 & 0,00 \\
\hline Maksimum & 4,00 & $4, \infty 0$ & 4,00 & 4,00 & 4,00 & $4, \infty 0$ & $4, \infty 0$ & 4,00 & 4,00 \\
\hline
\end{tabular}

Preglednica 29: Test Kolmogorov-Smirnova za posamezne faktorje vodenja

\begin{tabular}{lccc} 
& Statistic & df & Sig. \\
\hline Intelektualna stimulacija & 0,122 & 306 & 0,000 \\
\hline Idealiziran vpliv vedenje & 0,098 & 306 & 0,000 \\
\hline Navdihovalna motivacija & 0,137 & 306 & 0,000 \\
\hline Idealiziran vpliv pripisan & 0,093 & 306 & 0,000 \\
\hline Individualna obravnava & 0,118 & 306 & 0,000 \\
\hline Management zizjemami pasiven & 0,091 & 306 & 0,000 \\
\hline Management z izjemami aktiven & 0,098 & 306 & 0,000 \\
\hline Pogojevano nagrajevanje & 0,133 & 306 & 0,000 \\
\hline Vodenje laissez faire & 0,134 & 306 & 0,000 \\
\hline
\end{tabular}

Iz preglednice 28 je razvidno, da najvišje povprečje dosega faktor navdihovalna motivacija, kar kaže, da je bil pretežni del ocenjevanih vodij optimističen glede prihodnosti in da je verjel $v$ spremembo. Vodje so ime- 
li vizijo, jasno sliko prihodnosti, ki naj bi jo prinesla sprememba, in so znali postavljati cilje, o katerih so z navdušenjem govorili. Rezultat potrjuje nekatera spoznanja kvalitativne raziskave, $v$ kateri so mnogi intervjuvanci povedali, kako pomembno je bilo, da je bil vodja sam prepričan o spremembi - le na ta način so mu zaupali in mu sledili.

Najnižje povprečje dosegata faktorja management z izjemami (pasivni) in vodenje laissez-faire. $Z$ izjemo slednjih so bila povprečja vseh ostalih med 2,5 in 3. Rezultat pomeni, da so vodje, ki so ocenjevali sebe, ter zaposleni, ki so ocenjevali vodje, pozitivno ocenjevali ostalih sedem faktorjev oz. dimenzij vodenja.

Nizko povprečje pri faktorjih management $\mathrm{z}$ izjemami (pasivni) in vodenje laissez-faire kaže na dejstvo, da je bilo takšnega vodenja pri ocenjevanih osebah manj, kar pomeni, da se vodje niso izogibali sprejemanju odločitev, reševanju pomembnih vprašanj ter odlašali z nujnimi nalogami. Prav tako so bili prisotni, ko so jih zaposleni potrebovali.

Odgovori so bili pri vseh faktorjih homogeni, kar pomeni, da večjih odstopanj od povprečja ni bilo. Preverili smo tudi normalnost porazdelitve s testom Kolmogorov-Smirnova (preglednica 29), ki je pokazal, da spremenljivke niso porazdeljene približno normalno, saj je $\mathrm{p}<0,05 . \mathrm{V}$ nadaljevanju smo preverili koeficienta sploščenosti in asimetričnosti, ki sta bila znotraj \pm I, kar pomeni, da lahko domnevamo, da so faktorji porazdeljeni približno normalno, saj so testi normalnosti pri večjih vzorcih občutljivejši. Za nadaljnje analize smo tako uporabili parametrične teste.

Preglednica 30: Opisne statistike za stile vodenja

\begin{tabular}{|c|c|c|c|c|}
\hline & & Transformacijsko & Transakcijsko & Pasivno \\
\hline \multirow{2}{*}{ N } & Veljavni & 306 & 306 & 306 \\
\hline & Manjkajoči & 5 & 5 & 5 \\
\hline \multicolumn{2}{|c|}{ Povprečje } & 2,7656 & 2,7620 & 1,3692 \\
\hline \multicolumn{2}{|c|}{ Standardni odklon } & 0,68752 & 0,67548 & o,885ні \\
\hline \multicolumn{2}{|c|}{ Asimetričnost } & $-0,586$ & $-0,572$ & 0,448 \\
\hline \multicolumn{2}{|c|}{ Standardna napaka asimetričnosti } & 0,139 & 0,139 & 0,139 \\
\hline \multicolumn{2}{|c|}{ Sploščenost } & 0,232 & $-0,084$ & $-0,673$ \\
\hline \multicolumn{2}{|c|}{ St. napaka sploščenosti } & 0,278 & 0,278 & 0,278 \\
\hline \multicolumn{2}{|c|}{ Minimum } & 0,35 & 0,75 & 0,00 \\
\hline \multicolumn{2}{|c|}{ Maksimum } & 4,00 & 4,00 & 3,75 \\
\hline
\end{tabular}




\begin{tabular}{lccc} 
& Statistic & df & Sig. \\
\hline Transformacijsko & 0,057 & 306 & 0,019 \\
\hline Transakcijsko & 0,076 & 306 & 0,000 \\
\hline Pasivno & 0,106 & 306 & 0,000 \\
\hline
\end{tabular}

Povedali smo že, da smo v pasivno vodenje vključili dva faktorja (management z izjemami - pasivni) in vodenje laissez-faire vodenje. Preglednica 30 prikazuje opisne statistike za stile vodenja. V povprečju so vodje sprememb v bolnišnicah najmanj uporabljali pasivno vodenje, transformacijsko in transakcijsko vodenje pa v skoraj v enaki meri. Odgovori so bili pri vseh faktorjih homogeni (ni bilo večjih odstopanj od povprečij). Normalnost porazdelitve smo preverjali s testom Kolmogorov-Smirnova (preglednica 3i), ki je pokazal, da spremenljivke niso porazdeljene približno normalno. $\mathrm{V}$ nadaljevanju smo na podlagi koeficienta sploščenosti in asimetričnosti, ki je bil znotraj $\pm \mathrm{I}$, domnevali, da so faktorji porazdeljeni približno normalno (testi normalnosti so pri večjih vzorcih občutljivejši). Za nadaljnje analize smo uporabili parametrične teste.

Preglednica 32 prikazuje visoko povprečje uspešnosti. Anketiranci so bili v povprečju mnenja, da so bile uvedene spremembe uspešne. Odgovori so bili homogeni. Normalnost porazdelitve smo ugotavljali s testom Kolmogorov-Smirnova, ki je pokazal, da spremenljivka ni porazdeljena približno normalno, saj je $\mathrm{p}<0,05$ (preglednica 33). Preverili smo tudi koeficienta sploščenosti in asimetričnosti, ki sta bila znotraj $\pm \mathrm{I}$, kar pomeni, da lahko domnevamo, da je faktor porazdeljen približno normalno, saj so testi pri večji vzorcih občutljivejši.

Preglednica 32: Opisne statistike za uspešnost

\begin{tabular}{|c|c|c|}
\hline \multirow{2}{*}{$\mathbf{N}$} & Veljavni & 285 \\
\hline & Manjkajoči & 21 \\
\hline Povprečje & & $3,468 \mathrm{I}$ \\
\hline Standardni odklon & & 0,82513 \\
\hline Asimetričnost & & $-0,382$ \\
\hline Standardna napaka & & 0,144 \\
\hline Sploščenost & & 0,027 \\
\hline
\end{tabular}




\begin{tabular}{lll} 
& Veljavni & 285 \\
\cline { 2 - 3 } & Manjkajoči & 21 \\
Standardna napaka sploščenosti & 0,288 \\
\hline Minimum & 1,00 \\
\hline Maksimum & 5,00 \\
\hline
\end{tabular}

Preglednica 33: Test Kolmogorov-Smirnova za uspešnost

\begin{tabular}{lccc} 
& Statistic & df & Sig. \\
\hline Uspešnost & 0,133 & 285 & 0,000 \\
\hline
\end{tabular}

Analiza stilov vodenja glede na spol, vlogo in uspešnost

V nadaljnji analizi smo ugotavljali stile vodenja glede na spol.

Preglednica 34: Stili vodenja glede na spol

\begin{tabular}{llcccc} 
& \multicolumn{1}{c}{ Spol } & N & Povprečje & St. odklon & St. napaka \\
\multirow{2}{*}{$\begin{array}{l}\text { TRANSFOR- } \\
\text { MACIJSKO }\end{array}$} & Moški & 46 & 2,9603 & 0,53619 & 0,07906 \\
\cline { 2 - 6 } & Ženska & 231 & 2,7103 & 0,72325 & 0,04759 \\
\hline \multirow{2}{*}{$\begin{array}{l}\text { TRANSAKCI- } \\
\text { JSKO }\end{array}$} & Moški & 46 & 2,9225 & 0,61197 & 0,09023 \\
\cline { 2 - 5 } & Ženska & 231 & 2,7264 & 0,70226 & 0,04621 \\
\hline \multirow{2}{*}{ PASIVNO } & Moški & 46 & 1,0764 & 0,82160 & 0,12114 \\
\cline { 2 - 5 } & Ženska & 231 & 1,4501 & 0,89502 & 0,05889 \\
\hline
\end{tabular}

Analiza glede na spol je pokazala, da pri transakcijskem in pasivnem vodenju lahko domnevamo, da so variance približno homogene, saj rezultati Levenovega testa niso bili statistično pomembni ( $p>0,05)$, pri transformacijskem pa je bila vrednost Levenovega testa statistično pomembna $(\mathrm{p}<0,05)$, zato smo upoštevali Welchev popravek (preglednica 35). Pregled rezultatov t-testa za neodvisne vzorce je pokazal, da obstajajo statistično pomembne razlike $\mathrm{v}$ transformacijskem in pasivnem vodenju, pri transakcijskem pa so vrednosti na meji $(\mathrm{p}=0,057)$. Ženske so dosegle višje povprečje pri pasivnem vodenju, kar pomeni, da je pri njih ta stil vodenja bolj izražen. Uspešnost, transakcijsko in transformacijsko vodenje pa so bolj izraženi pri moških, saj so pri njih dosegli višje povprečje v primerjavi z ženskami, kar pomeni, da so moški uvedene spremembe v večji meri ocenjevali kot uspešne. Pri moških je tudi nekoliko bolj izražen transfor- 
macijski stil vodenja, čeprav raziskave v svetu kažejo ravno obratno, namreč da ženske pogosteje uporabljajo transformacijski stil vodenja.

Preglednica 35: T-test za neodvisne vzorce

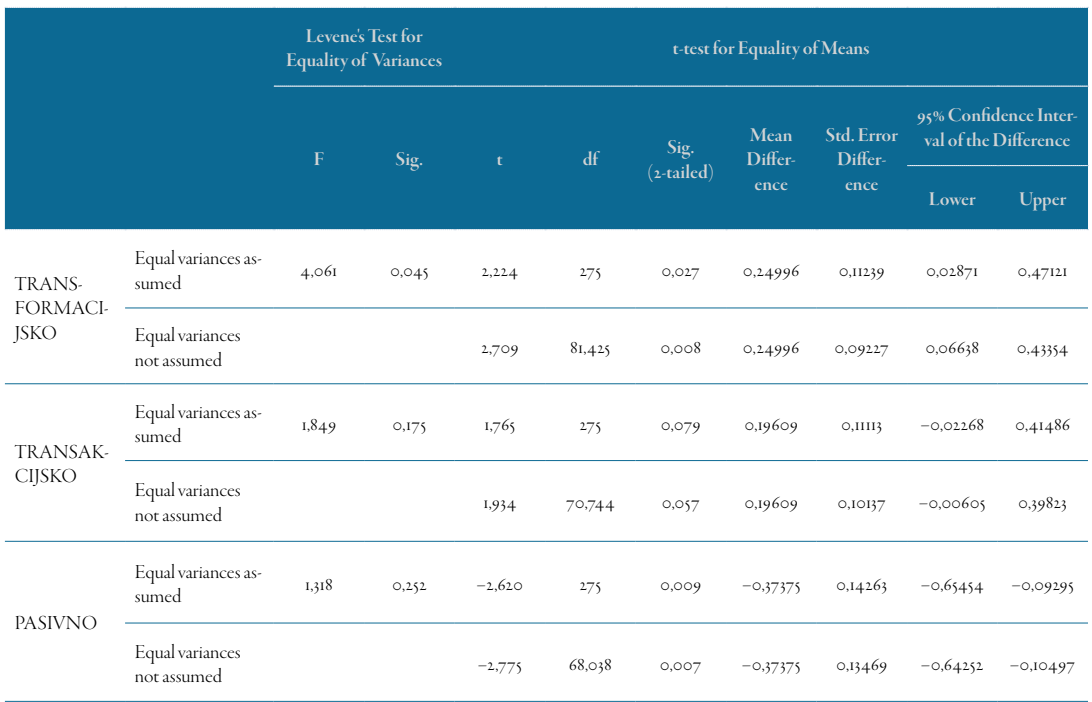

Analiza sprememb glede na vlogo anketirancev je pokazala, da so direktorji in vodje projektov spremembe največkrat ocenjevali kot inkrementalne spremembe, tako temeljnih dejavnosti kot perifernih dejavnosti. RP-spremembe so bile najbolj izražene pri sodelavcih, medtem ko so bile RT-spremembe najbolj izražene pri sodelavcih in direktorjih (preglednica 36). 
Vodenje sprememb v zdravstvenih organizacijah

Preglednica 36: Vrste sprememb glede na vlogo

\begin{tabular}{|c|c|c|c|c|c|c|c|c|c|}
\hline & & \multirow{2}{*}{$\mathbf{N}$} & \multirow{2}{*}{ Povprečje } & \multirow{2}{*}{ St. odklon } & \multirow{2}{*}{ St. napaka } & \multicolumn{2}{|c|}{$\begin{array}{l}95 \% \text { Confidence Inter- } \\
\text { val for Povprečje }\end{array}$} & \multirow{2}{*}{ Minimum } & \multirow{2}{*}{$\begin{array}{r}\text { Maksi- } \\
\text { mum }\end{array}$} \\
\hline & & & & & & $\begin{array}{l}\text { Lower } \\
\text { Bound }\end{array}$ & $\begin{array}{l}\text { Upper } \\
\text { Bound }\end{array}$ & & \\
\hline \multirow{5}{*}{ IT-spremembe } & Direktor & 6 & $3,56 \mathrm{II}$ & 0,72921 & 0,29770 & 2,7959 & 4,3264 & 2,40 & 4,67 \\
\hline & Vodja projekta & 45 & 3,6589 & 0,74666 & O,III30 & 3,4346 & 3,8832 & 1,00 & 5,00 \\
\hline & Sodelavec & I5I & 3,2678 & 0,73496 & $0,0598 \mathrm{I}$ & 3,1496 & 3,3860 & 1,00 & 5,00 \\
\hline & Drugo & 43 & 3,2105 & 0,96779 & 0,14759 & 2,9126 & 3,5083 & 1,00 & 5,00 \\
\hline & Skupaj & 245 & 3.3367 & 0,79426 & 0,05074 & 3,2368 & 3,4367 & 1,00 & 5,00 \\
\hline \multirow{5}{*}{ IP-spremembe } & Direktor & 5 & 3,7333 & $0,4944 \mathrm{I}$ & $0,22 \mathrm{III}$ & 3,1194 & 4,3472 & 3,00 & 4,17 \\
\hline & Vodja projekta & 49 & 3,6354 & 0,69166 & $0,0988 \mathrm{I}$ & 3,4367 & 3,8340 & 2,33 & 5,00 \\
\hline & Sodelavec & 153 & 3,3308 & 0,74755 & 0,06044 & 3,2114 & 3,4502 & 1,00 & 5,00 \\
\hline & Drugo & 46 & $3,534 \mathrm{I}$ & 0,70590 & 0,10408 & 3,3244 & 3,7437 & 1,67 & 5,00 \\
\hline & Skupaj & 253 & 3,4347 & 0,73417 & 0,04616 & 3,3438 & 3,5256 & 1,00 & 5,00 \\
\hline \multirow{5}{*}{ RP-spremembe } & Direktor & 5 & 2,7000 & 0,57009 & 0,25495 & I,992I & 3,4079 & 2,00 & 3,50 \\
\hline & Vodja projekta & 47 & 2,7500 & 1,06832 & 0,15583 & 2,4363 & 3,0637 & 1,00 & 5,00 \\
\hline & Sodelavec & 153 & 2,8350 & 0,87950 & 0,07110 & 2,6945 & 2,9754 & 1,00 & 4,75 \\
\hline & Drugo & 47 & 2,8298 & 0,94280 & 0,13752 & 2,5530 & 3,1066 & 1,00 & 4,75 \\
\hline & Skupaj & 252 & 2,8155 & 0,92033 & 0,05798 & 2,7013 & 2,9297 & 1,00 & 5,00 \\
\hline \multirow{5}{*}{ RT-spremembe } & Direktor & 5 & 2,7200 & 0,30332 & 0,13565 & 2,3434 & 3,0966 & $2,4 \circ$ & 3,20 \\
\hline & Vodja projekta & 45 & 2,3067 & 1,07928 & 0,16089 & 1,9824 & 2,6309 & $1, \infty 0$ & 4,60 \\
\hline & Sodelavec & I5I & 2,7247 & 0,88173 & 0,07175 & 2,5829 & 2,8665 & 1,00 & 5,00 \\
\hline & Drugo & 45 & 2,6356 & 0,84904 & 0,12657 & 2,3805 & 2,8906 & $1, \infty 0$ & $4, \infty 0$ \\
\hline & Skupaj & 246 & 2,6318 & 0,91709 & 0,05847 & 2,5167 & $2,747^{\circ}$ & 1,00 & 5,00 \\
\hline
\end{tabular}

$\mathrm{Z}$ nadaljnjo analizo smo ugotavljali stile vodenja glede na vloge zaposlenih. Preglednica 37 prikazuje, da imajo najbolj izraženo transformacijsko vodenje vodje projekta, medtem ko so sodelavci, ki so ocenjevali vodje, transformacijsko vodenje ocenili nižje. Rezultat je skladen s spoznanji raziskovalcev, da vodja sam sebe oceni bolje, kot ga ocenijo sodelavci. Vodje so se $\mathrm{v}$ manjši meri ocenjevali kot pasivni, medtem ko so jim ta stil vodenja sodelavci in drugi pripisali v večji meri. Transakcijsko vodenje pa je najbolj izraženo pri vodjih projekta, medtem ko je najmanj izraženo pri direktorjih. 
Preglednica 37: Stili vodenja glede na vlogo

\begin{tabular}{|c|c|c|c|c|c|c|c|c|c|}
\hline & & \multirow{2}{*}{$\mathbf{N}$} & \multirow{2}{*}{ Povprečje } & \multirow{2}{*}{ St.odklon } & \multirow{2}{*}{ St. napaka } & \multicolumn{2}{|c|}{$\begin{array}{l}95 \% \text { Confidence } \\
\text { Interval for Mean }\end{array}$} & \multirow{2}{*}{ Minimum } & \multirow{2}{*}{ Maximum } \\
\hline & & & & & & $\begin{array}{l}\text { Lower } \\
\text { Bound }\end{array}$ & $\begin{array}{l}\text { Upper } \\
\text { Bound }\end{array}$ & & \\
\hline \multirow{5}{*}{$\begin{array}{l}\text { TRANSFOR- } \\
\text { MACIJSKO }\end{array}$} & Direktor & 6 & 2,8224 & 0,63857 & 0,26070 & 2,1522 & 3,4925 & 1,95 & 3.55 \\
\hline & Vodja projekta & 49 & $3,077^{2}$ & 0,47701 & 0,06814 & 2,9402 & 3,2142 & 2,00 & 4,00 \\
\hline & Sodelavec & I54 & 2,7044 & 0,71023 & 0,05723 & 2,5913 & 2,8175 & 0,35 & 4,00 \\
\hline & Drugo & 49 & 2,7216 & 0,70394 & 0,10056 & 2,5194 & 2,9238 & $\mathrm{I}, \mathrm{IS}$ & 4,00 \\
\hline & Skupaj & 258 & 2,7812 & 0,68135 & 0,04242 & 2,6977 & 2,8647 & 0,35 & 4,00 \\
\hline \multirow{5}{*}{$\begin{array}{l}\text { TRANSAKCI- } \\
\text { JSKO }\end{array}$} & Direktor & 6 & 2,5417 & 0,69672 & 0,28443 & 1,8105 & 3,2728 & 1,50 & 3,13 \\
\hline & Vodja projekta & 49 & 3,0549 & 0,53109 & 0,07587 & 2,9024 & 3,2075 & 1,50 & 3,75 \\
\hline & Sodelavec & 154 & 2,6976 & 0,67337 & 0,05426 & 2,5904 & $2,8 \circ 48$ & 0,75 & 3,88 \\
\hline & Drugo & 49 & $2,715 \mathrm{I}$ & 0,79315 & 0,11331 & 2,4873 & 2,9430 & 1,00 & 3,88 \\
\hline & Skupaj & 258 & 2,7652 & 0,68553 & 0,04268 & 2,68II & 2,8492 & 0,75 & 3,88 \\
\hline \multirow{5}{*}{ PASIVNO } & Direktor & 6 & 1,6042 & 0,89239 & 0,36432 &, 6677 & 2,5407 & 0,13 & 2,63 \\
\hline & Vodja projekta & 49 & $\mathrm{I}, 0434$ & 0,67919 & 0,09703 & 8483 & 1,2385 & 0,13 & 3,50 \\
\hline & Sodelavec & 154 & 1,3916 & 0,92318 & 0,07439 & 1,2446 & 1,5386 & 0,00 & 3,75 \\
\hline & Drugo & 49 & 1,6822 & 0,91753 & 0,13108 & 1,4186 & 1,9457 & 0,13 & 3,10 \\
\hline & Skupaj & 258 & 1,3856 & 0,89805 & 0,05591 & 1,2755 & 1,4957 & 0,00 & 3,75 \\
\hline
\end{tabular}

Analizirali smo tudi stile vodenja glede na uspešnost. Pri uspešnosti smo na podlagi izračunane mediane anketirance razdelili v dve skupini, in sicer tiste, ki so dosegli oceno do 3,49, v skupino neuspešnih, in tiste, ki so dosegli oceno 3,5 ali več, v skupino uspešnih.

Preglednica 38: Kategoriji uspešnosti

\begin{tabular}{|c|c|c|c|c|c|}
\hline \multicolumn{6}{|c|}{ Group Statistics } \\
\hline & Uspešnost kategorije & $\mathbf{N}$ & Povprečje & St. odklon & St. napaka \\
\hline \multirow{2}{*}{ TRANSFORMACIJSKO } & Neuspešni & 117 & $2,375^{8}$ & 0,69044 & 0,06383 \\
\hline & Uspešni & 163 & 3,0180 & 0,55243 & 0,04327 \\
\hline \multirow{2}{*}{ TRANSAKCIJSKO } & Neuspešni & 117 & 2,4066 & 0,68032 & 0,06290 \\
\hline & Uspešni & 163 & 3,0060 & 0,56520 & 0,04427 \\
\hline
\end{tabular}




\begin{tabular}{llllll}
\multicolumn{7}{c}{ Group Statistics } \\
\hline Uspešnost kategorije & N & Povprečje & St. odklon & St. napaka \\
\hline PASIVNO & Neuspešni & 117 & 1,6706 & 0,79731 & 0,07371 \\
\cline { 2 - 6 } & Uspešni & 163 & 1,1979 & 0,90223 & 0,07067 \\
\hline
\end{tabular}

Preglednica 39: Test neodvisnih vzorcev

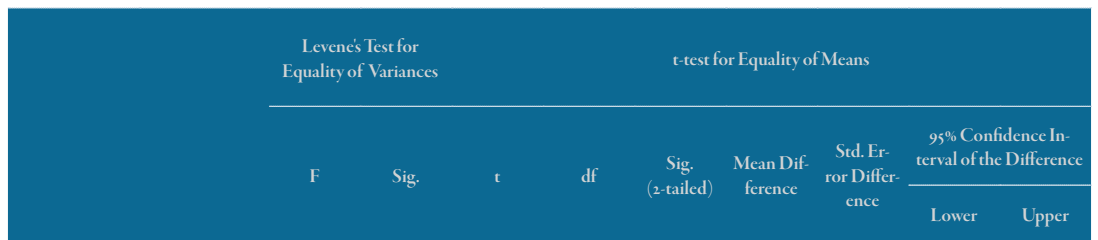

\begin{tabular}{|c|c|c|c|c|c|c|c|c|c|c|}
\hline \multirow{2}{*}{$\begin{array}{l}\text { TRANSFOR- } \\
\text { MACIJSKO }\end{array}$} & $\begin{array}{l}\text { Equal variances } \\
\text { assumed }\end{array}$ & 5,782 & 0,017 & $-8,635$ & 278 &, 000 & $-0,64222$ & 0,07437 & $-0,78863$ & $-0,4958 \mathrm{I}$ \\
\hline & $\begin{array}{l}\text { Equal variances } \\
\text { not assumed }\end{array}$ & & & $-8,328$ & 214,647 &, 000 & $-0,64222$ & 0,07711 & $-0,79422$ & $-0,49022$ \\
\hline \multirow{2}{*}{$\begin{array}{l}\text { TRANSAK- } \\
\text { CIJSKO }\end{array}$} & $\begin{array}{l}\text { Equal variances } \\
\text { assumed }\end{array}$ & 4,006 & 0,046 & $-8,031$ & 278 &,,$\infty \circ 0$ & $-0,59931$ & 0,07462 & $-0,74621$ & $-0,45241$ \\
\hline & $\begin{array}{l}\text { Equal variances } \\
\text { not assumed }\end{array}$ & & & $-7,792$ & 220,632 &,,$\infty 00$ & $-0,59931$ & 0,07691 & $-0,75089$ & $-0,44773$ \\
\hline \multirow{2}{*}{ PASIVNO } & $\begin{array}{l}\text { Equal variances } \\
\text { assumed }\end{array}$ & 1,174 & 0,280 & 4,536 & 278 &, 000 & 0,47268 & 0,10421 & 0,26755 & $0,6778 \mathrm{I}$ \\
\hline & $\begin{array}{l}\text { Equal variances } \\
\text { not assumed }\end{array}$ & & & 4,629 & 266,203 &,,$\infty 00$ & 0,47268 & 0,10211 & 0,27162 & 0,67373 \\
\hline
\end{tabular}

Iz preglednice 39 je razvidno, da pri transakcijskem in transformacijskem vodenju ne moremo predpostaviti homogenosti varianc, saj so bili rezultati Levenovega testa statistično pomembni $(p>0,05)$. Zato smo upoštevali Welchev popravek t-testa za neodvisne vzorce. Pri pasivnem vodenju smo lahko predpostavili, da so variance približno homogene, saj Levenov test ni bil statistično pomemben $(\mathrm{p}>0,05)$. Rezultati t-testa za neodvisne vzorce so pokazali, da obstaja statistično pomembna razlika $\mathrm{v}$ uspešnosti med transformacijskim, transakcijskim in pasivnim vodenjem, in sicer so imeli uspešni višje povprečje pri obeh faktorjih (TF in TS), kar pomeni, da sta bila oba stila vodenja pri njih v primerjavi z neuspešnimi bolj izražena. Pri pasivnem vodenju pa se je pokazalo, da imajo neuspešni bolj izražen pasivni način vodenja, saj so pri tem faktorju dosegli višje povprečje. 


\section{Rezultati regresijske analize}

V nadaljevanju smo naredili regresijsko analizo, pri kateri so izoblikovani faktorji predstavljali odvisno spremenljivko.

Za posamezne reziduale smo izračunali normalnost porazdelitve s testom Kolmogorov-Smirnova, ki je pokazal, da lahko domnevamo, da vsi reziduali niso porazdeljeni približno normalno, saj so rezultati pri določenih statistično pomembni $(\mathrm{p}<0,05)$. Vendar smo ponovno preverili vrednosti koeficientov asimetričnosti in sploščenosti, ki so med \pm I, torej lahko zaključimo, da so reziduali porazdeljeni približno normalno in je ena izmed predpostavk regresijske analize izpolnjena (preglednici 40 in $4 \mathrm{I}$ ).

Preglednica 40: Test Kolmogorov-Smirnova za reziduale

\begin{tabular}{lccl} 
& Statistic & df & Sig. \\
\hline SR Uspešnost & 0,052 & $26 \mathrm{I}$ & 0,088 \\
\hline SR IT-spremembe & 0,059 & $26 \mathrm{I}$ & 0,028 \\
\hline SR IP-spremembe & 0,072 & $26 \mathrm{I}$ & 0,002 \\
\hline SR RP-spremembe & 0,054 & $26 \mathrm{I}$ & 0,063 \\
\hline SR RT-spremembe & 0,072 & $26 \mathrm{I}$ & 0,002 \\
\hline
\end{tabular}

Preglednica 41: Koeficienti asimetričnosti in sploščenosti

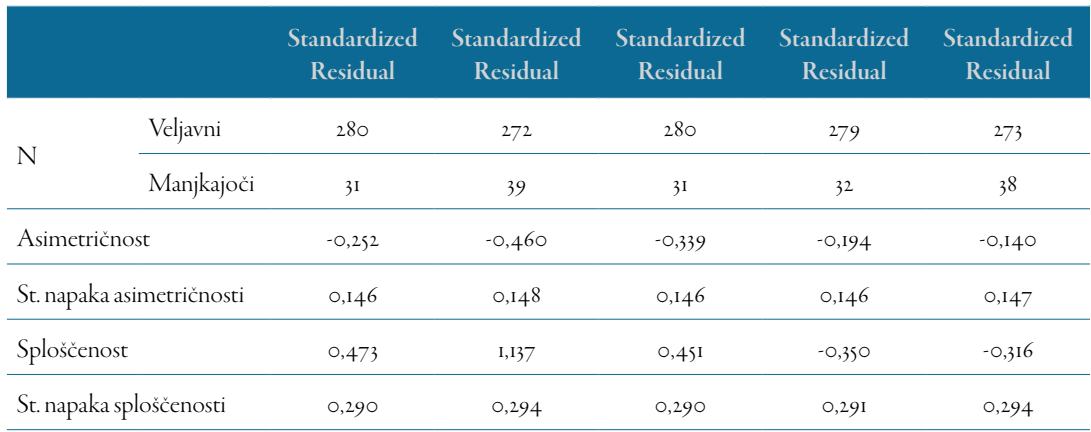

\section{Proi regresijskimodel}

V prvem regresijskem modelu smo kot odvisno spremenljivko uporabili faktor uspešnost. 


\begin{tabular}{|c|c|c|c|c|c|}
\hline Model & $\mathbf{R}$ & R Square & $\begin{array}{l}\text { Adjusted } \\
\text { R Square }\end{array}$ & $\begin{array}{c}\text { Std. Error } \\
\text { of the Estimate }\end{array}$ & Durbin-Watson \\
\hline I & $0,506 \mathrm{a}$ & 0,256 & 0,248 & 0,71841 & 1,705 \\
\hline
\end{tabular}

a. Predictors: (Constant), PASIVNO, TRANSFORMACIJSKO, TRANSAKCIJSKO

b. Dependent Variable: Uspešnost

Iz preglednice 42 je razvidno, da znaša multipla korelacija 0,51 , in da kombinacija vseh neodvisnih spremenljivk pojasni $25,6 \%$ variabilnosti odvisne spremenljivke uspešnost. Vrednost Durbin-Watsonovega testa znaša nad I in manj kot 3 , kar pomeni, da lahko domnevamo, da so napake neodvisne, kar je ena izmed predpostavk večkratne regresije. SprememI84 ba $\mathrm{R}^{2}$ je statistično pomembna, kar pomeni, da se model dobro prilega podatkom in da vsaj ena izmed neodvisnih spremenljivk statistično pomembno pojasni razpršenost odvisne spremenljivke $(\mathrm{p}<0,05)$, kar je razvidno iz preglednice 43 .

Preglednica 43: ANOVA za uspešnost

\begin{tabular}{|c|c|c|c|c|c|c|}
\hline & Model & Sum of Squares & df & Mean Square & F & Sig. \\
\hline & Regression & 49,067 & 3 & 16,356 & 31,690 & o, ০oob \\
\hline \multirow[t]{2}{*}{ I } & Residual & 142,447 & 276 & 0,516 & & \\
\hline & Total & 191,514 & 279 & & & \\
\hline
\end{tabular}

a. Dependent Variable: Uspešnost

b. Predictors: (Constant), PASIVNO, TRANSFORMACIJSKO, TRANSAKCIJSKO

Preglednica 44: Regresijski koeficienti za uspešnost

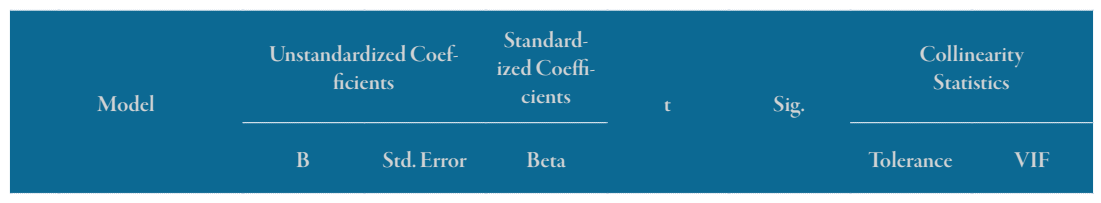

\begin{tabular}{|c|c|c|c|c|c|c|c|}
\hline (Constant) & 2,077 & 0,237 & & 8,745 & ০,০০০ & & \\
\hline Transformacijsko & 0,277 & 0,126 & $0,23 \mathrm{I}$ & 2,205 & 0,028 & 0,246 & 4,069 \\
\hline Transakcijsko & 0,285 & 0,128 & 0,235 & 2,237 & 0,026 & 0,244 & 4,098 \\
\hline Pasivno & $-0,106$ & 0,053 & $-0,114$ & $-2, \mathrm{OII}$ & 0,045 & 0,843 & $\mathrm{I}, \mathrm{I} 86$ \\
\hline
\end{tabular}


Preglednica 44 razkriva, da vsi trije stili statistično pomembno pojasnijo razpršenost odvisne spremenljivke uspešnosti. Če preverimo beta koeficiente, lahko ugotovimo, da imata najvišji vpliv na uspešnost transformacijsko in transakcijsko vodenje, vpliv pasivnega vodenja pa je ravno obraten, čeprav manjši. Beta koeficient pomeni, da če se transformacijsko/transakcijsko vodenje poveča za I standardno deviacijo, se uspešnost poveča za o,23I/o,235 standardne deviacije. Vse vrednosti VIF so pod Io in nad o,2, kar pomeni, da lahko domnevamo, da z multikolineranostjo ali kolinearnostjo nimamo težav.

\section{Drugi regresijskimodel}

V drugem regresijskem modelu smo kot odvisno spremenljivko uporabili faktor IT-spremembe.

Preglednica 45: Pojasnjenost regresijskega modela za IT-spremembe

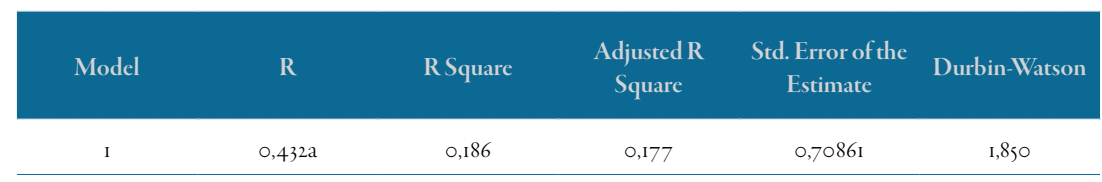

a. Predictors: (Constant), PASIVNO, TRANSFORMACIJSKO, TRANSAKCIJSKO

b. Dependent Variable: IT-spremembe

Preglednica 45 prikazuje, da znaša multipla korelacija 0,43 in da kombinacija vseh neodvisnih spremenljivk pojasni samo i 8,6 \% variabilnosti odvisne spremenljivke IT-spremembe. Vrednost Durbin-Watsonovega testa je nad I in manj kot 3, kar pomeni, da lahko domnevamo, da so napake neodvisne. To je ena izmed predpostavk večkratne regresije. Sprememba $v \mathrm{R}^{2}$ je statistično pomembna, prav tako se model dobro prilega podatkom, saj je statistično pomemben $(\mathrm{p}=0,000<0,05)$. Vsaj ena izmed neodvisnih spremenljivk statistično pomembno pojasni razpršenost odvisne spremenljive, kar je razvidno iz preglednice 46 . 


\begin{tabular}{lccccc} 
Model & Sum of Squares & df & Mean Square & F & Sig. \\
\hline Regression & 30,842 & 3 & 10,281 & 20,474 & $0,000 \mathrm{~b}$ \\
\cline { 2 - 5 } Residual & $134,57 \mathrm{I}$ & 268 & 0,502 & \\
\cline { 2 - 5 } Total & 165,412 & $27 \mathrm{I}$ & & \\
\hline
\end{tabular}

a. Dependent Variable: IT-spremembe

b. Predictors: (Constant), PASIVNO, TRANSFORMACIJSKO, TRANSAKCIJSKO

Preglednica 47: Regresijski koeficienti za IT-spremembe

\begin{tabular}{|c|c|c|c|c|c|c|c|c|}
\hline & \multirow{2}{*}{ Model } & \multicolumn{2}{|c|}{$\begin{array}{l}\text { Unstandardized Coef- } \\
\text { ficients }\end{array}$} & \multirow{2}{*}{$\begin{array}{c}\begin{array}{c}\text { Standard- } \\
\text { ized Coef- } \\
\text { ficients }\end{array} \\
\text { Beta }\end{array}$} & \multirow{2}{*}{$\mathrm{t}$} & \multirow{2}{*}{ Sig. } & \multicolumn{2}{|c|}{ Collinearity Statistics } \\
\hline & & B & Std. Error & & & & Tolerance & VIF \\
\hline \multirow{4}{*}{ I } & (Constant) & $\mathrm{I}, 97 \mathrm{I}$ & 0,236 & & 8,370 & 0,000 & & \\
\hline & Transformacijsko & $0,3 \mathrm{II}$ & 0,123 & 0,277 & 2,521 & 0,012 & 0,252 & 3,973 \\
\hline & Transakcijsko & 0,193 & 0,126 & 0,169 & 1,532 & 0,127 & 0,250 & 3,997 \\
\hline & Pasivno & $-0,001$ & 0,052 & $-0,002$ & $-0,027$ & 0,978 & 0,849 & $\mathrm{I}, \mathrm{1} 77$ \\
\hline
\end{tabular}

\section{a. Dependent Variable: IT-spremembe}

Preglednica 47 kaže, da transformacijsko vodenje statistično pomembno pojasni razpršenost odvisne spremenljivke IT-spremembe. Povezava je pozitivna, kar pomeni, da se $\mathrm{z}$ večanjem transformacijskega vodenja veča obseg uvedenih IT-sprememb. Beta koeficienti povedo, da ima na IT-spremembe najvišji vpliv transformacijsko vodenje. Vpliv transakcijskega vodenja je manjši, vendar še vedno obstaja pozitivna povezava, medtem ko je vpliv pasivnega vodenja zanemarljiv. Beta koeficient pove, da ko se transformacijsko vodenje poveča za I standardno deviacijo, se obseg IT-sprememb poveča za 0,28 standardne deviacije. Vse vrednosti VIF so pod Io in vrednosti tolerance nad o,2, zato lahko domnevamo, da $\mathrm{z}$ multikolineranostjo ali kolinearnostjo ni težav.

\section{Tretji regresijskimodel}

$\mathrm{V}$ tretjem regresijskem modelu smo kot odvisno spremenljivko uporabili faktor IP-spremembe. 
Preglednica 48: Pojasnjenost regresijskega modela za IP-spremembe

\begin{tabular}{cccccc} 
Model Summaryb & \\
Model & R & R Square & $\begin{array}{c}\text { Adjusted R } \\
\text { Square }\end{array}$ & $\begin{array}{c}\text { Std. Error of the } \\
\text { Estimate }\end{array}$ & Durbin-Watson \\
\hline I & $0,328 \mathrm{a}$ & 0,107 & 0,098 & 0,71292 & $\mathrm{I}, 677$ \\
\hline
\end{tabular}

a. Predictors: (Constant), PASIVNO, TRANSFORMACIJSKO, TRANSAKCIJSKO

b. Dependent Variable: IP-spremembe

Preglednica 48 kaže, da multipla korelacija znaša o,33. Kombinacija vseh neodvisnih spremenljivk pojasni samo I0,7 \% variabilnosti odvisne spremenljivke IP-spremembe. Vrednost Durbin-Watsonovega testa znaša nad $\mathrm{I}$ in manj kot 3. Domnevamo, da so napake neodvisne in $s$ tem je ena od predpostavk večkratne regresije izpolnjena. Sprememba v $\mathrm{R}^{2}$ je statistično pomembna, prav tako se model dobro prilega podatkom. Vsaj ena izmed neodvisnih spremenljivk statistično pomembno pojasni razpršenost odvisne spremenljive $(\mathrm{p}=0,000<0,05)$, kar je razvidno iz preglednice 49.

Preglednica 49: ANOVA za IP-spremembe

\begin{tabular}{|c|c|c|c|c|c|c|}
\hline & \multicolumn{6}{|c|}{ ANOVAa } \\
\hline & Model & Sum of Squares & df & Mean Square & $\mathbf{F}$ & Sig. \\
\hline \multirow{3}{*}{ I } & Regression & 16,853 & 3 & 5,618 & 11,053 & $0,000 \mathrm{~b}$ \\
\hline & Residual & 140,277 & 276 & 0,508 & & \\
\hline & Total & 157,131 & 279 & & & \\
\hline
\end{tabular}

a. Dependent Variable: IP-spremembe

b. Predictors: (Constant), PASIVNO, TRANSFORMACIJSKO, TRANSAKCIJSKO 
Preglednica 5o: Regresijski koeficienti za IP-spremembe

\begin{tabular}{|c|c|c|c|c|c|c|c|c|}
\hline & & & & Coefficient & & & & \\
\hline & & Unst: & ardized & $\begin{array}{l}\text { Standard- } \\
\text { ized Coef- }\end{array}$ & & & Collineari & tatistics \\
\hline & & B & Std. Error & Beta & & & Tolerance & VIF \\
\hline & (Constant) & 2,390 & 0,235 & & 10,169 & 0,000 & & \\
\hline & Transformacijsko & 0,252 & 0,124 & 0,232 & 2,036 & 0,043 & 0,248 & 4,029 \\
\hline & Transakcijsko & O,II9 & 0,126 & 0,108 & 0,942 & 0,347 & 0,246 & 4,063 \\
\hline & Pasivno & 0,006 & 0,052 & 0,008 & 0,122 & 0,903 & 0,845 & $\mathrm{I}, \mathrm{I} 84$ \\
\hline
\end{tabular}

Iz preglednice so lahko razberemo, da transformacijsko vodenje statistično pomembno pojasni razpršenost odvisne spremenljivke IP-spremembe, in sicer je povezava pozitivna. Beta koeficienti povedo, da ima transformacijsko vodenje najvišji vpliv na IP-spremembe, vpliv transakcijskega vodenja je manjši, vendar še vedno obstaja pozitivna povezava, medtem ko je vpliv pasivnega vodenja zanemarljiv. Vse vrednosti VIF so pod $o$ in vrednosti tolerance nad o,2, zato lahko domnevamo, da z multikolineranostjo ali kolinearnostjo nimamo težav.

\section{Četrti regresijskimodel}

$\mathrm{V}$ četrtem regresijskem modelu smo kot odvisno spremenljivko uporabili RP-spremembe.

Preglednica 5 1: Pojasnjenost regresijskega modela za RP-spremembe

\begin{tabular}{cccccc} 
Model Summaryb & & \\
Model & R & R Square & $\begin{array}{c}\text { Adjusted R } \\
\text { Square }\end{array}$ & $\begin{array}{c}\text { Std. Error } \\
\text { of the Estimate }\end{array}$ & Durbin-Watson \\
\hline I & $0,280 a$ & 0,078 & 0,068 & 0,87500 & I,689 \\
\hline
\end{tabular}

a. Predictors: (Constant), PASIVNO, TRANSFORMACIJSKO, TRANSAKCIJSKO

b. Dependent Variable: RP-spremembe

V preglednici 5 I vidimo, da znaša multipla korelacija 0,28 . Kombinacija vseh neodvisnih spremenljivk pojasni samo 7,8 \% variabilnosti odvi- 
sne spremenljivke RP-spremembe. Vrednost Durbin-Watsonovega testa znaša nad $I$ in manj kot 3. Tudi sprememba $v R^{2}$ je statistično pomembna. Model se dobro prilega podatkom in vsaj ena neodvisna spremenljivka statistično pomembno pojasni razpršenost odvisne spremenljivke, kar je razvidno iz preglednice 52 , saj je vrednost statistično pomembna ( $\mathrm{p}=$ $0,000<0,05)$.

Preglednica 52: ANOVA za RP-spremembe

\begin{tabular}{|c|c|c|c|c|c|c|}
\hline & \multicolumn{6}{|c|}{ ANOVAa } \\
\hline & Model & Sum of Squares & df & Mean Square & F & Sig. \\
\hline \multirow{3}{*}{ I } & Regression & 17,879 & 3 & 5,960 & 7,784 & $0,000 b$ \\
\hline & Residual & 210,545 & 275 & 0,766 & o, & \\
\hline & Total & 228,424 & 278 & & & \\
\hline
\end{tabular}

a. Dependent Variable: RP-spremembe

b. Predictors: (Constant), PASIVNO, TRANSFORMACIJSKO, TRANSAKCIJSKO

Preglednica 53: Regresijski koeficienti za RP-spremembe

\begin{tabular}{|c|c|c|c|c|c|c|c|c|}
\hline & & & & Coefficient & & & & \\
\hline & Modd & $\begin{array}{r}\text { Unst } \\
\mathrm{Co}\end{array}$ & $\begin{array}{l}\text { ardized } \\
\text { cients }\end{array}$ & $\begin{array}{l}\text { Standard- } \\
\text { ized Coef- }\end{array}$ & & Sin & $\begin{array}{r}\text { Collir } \\
\text { Stat }\end{array}$ & \\
\hline & & B & Std. Error & Beta & & & Tolerance & VIF \\
\hline & (Constant) & $\mathrm{I}, 458$ & 0,288 & & 5,060 & 0,000 & & \\
\hline & Transformacijsko & 0,248 & 0,153 & 0,190 & 1,625 & 0,105 & 0,246 & 4,069 \\
\hline & Transakcijsko & 0,136 & 0,156 & 0,102 & 0,873 & 0,383 & 0,244 & 4,096 \\
\hline & Pasivno & 0,214 & 0,064 & $0,2 \mathrm{II}$ & 3,354 & 0,001 & 0,847 & 1,180 \\
\hline
\end{tabular}

a. Dependent Variable: RP-spremembe

Preglednica 53 razkriva, da pasivno vodenje statistično pomembno pojasni razpršenost odvisne spremenljivke RP-spremembe. Povezava je pozitivna, kar pomeni, da se $\mathrm{z}$ večanjem pasivnega vodenja večajo tudi RP-spremembe. Če preverimo beta koeficiente, lahko ugotovimo, da ima vpliv na RP-spremembe tudi transformacijsko vodenje, vpliv transakcijskega vodenja na RP-spremembe pa je manjši. Vse vrednosti VIF so pod 
Io in tolerančne vrednosti nad o,2, zato tudi v tem primeru domnevamo, da težav z multikolinearnostjo in kolinearnostjo ni.

\section{Peti regresijskimodel}

$\mathrm{V}$ petem regresijskem modelu smo kot odvisno spremenljivko uporabili faktor RT-spremembe.

Preglednica 54: Pojasnjenost regresijskega modela za RT-spremembe

\begin{tabular}{|c|c|c|c|c|c|}
\hline \multicolumn{6}{|c|}{ Model Summaryb } \\
\hline Model & $\mathbf{R}$ & R Square & $\begin{array}{l}\text { Adjusted R } \\
\text { Square }\end{array}$ & $\begin{array}{c}\text { Std. Error } \\
\text { of the Estimate }\end{array}$ & Durbin-Watson \\
\hline I & $0,309 a$ & 0,096 & 0,086 & 0,88453 & 1,737 \\
\hline
\end{tabular}

a. Predictors: (Constant), PASIVNO, TRANSFORMACIJSKO, TRANSAKCIJSKO

b. Dependent Variable: RT-spremembe

Preglednica 54 prikazuje, da kombinacija vseh treh neodvisnih spremenljivk pojasni samo 9,6 \% variabilnosti odvisne spremenljivke RT-spremembe. Multipla korelacija znaša 0,3 I. Vrednost Durbin-Watsonovega testa je med $\mathrm{I}$ in 3, zato domnevamo, da so napake neodvisne (predpostavka večkratne regresije). Preglednica 55 kaže, da vsaj ena neodvisna spremenljivka statistično pomembno pojasni razpršenost odvisne spremenljivke $(\mathrm{p}=0,000<0,05)$.

Preglednica 55: ANOVA za RT-spremembe

\begin{tabular}{|c|c|c|c|c|c|c|}
\hline & \multicolumn{6}{|c|}{ ANOVAa } \\
\hline & Model & Sum of Squares & df & Mean Square & $\mathbf{F}$ & Sig. \\
\hline \multirow{3}{*}{ I } & Regression & 22,272 & 3 & 7,424 & 9,489 & $0,000 \mathrm{~b}$ \\
\hline & Residual & 210,466 & 269 & 0,782 & & \\
\hline & Total & 232,737 & 272 & & & \\
\hline
\end{tabular}

a. Dependent Variable: RT-spremembe

b. Predictors: (Constant), PASIVNO, TRANSFORMACIJSKO, TRANSAKCIJSKO 
Preglednica 56: Regresijski koeficienti za RT-spremembe

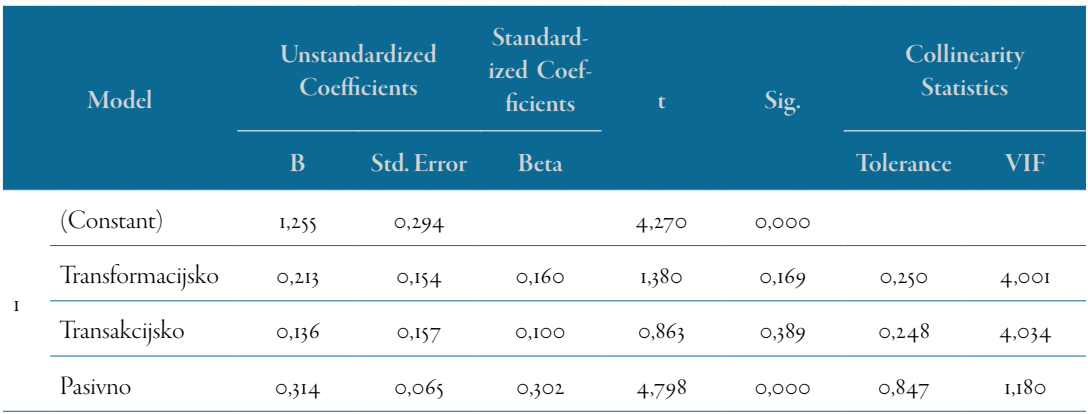

a. Dependent Variable: RT-spremembe

Iz preglednice 56 lahko razberemo, da pasivno vodenje statistično pomembno pojasni razpršenost odvisne spremenljivke RT-spremembe. Povezava med njima je pozitivna. Pogled na beta koeficiente pokaže, da ima na RT-spremembe v manjši meri vpliv transformacijsko vodenje, najmanjši vpliv pa transakcijsko vodenje. Izpolnjena je še ena izmed predpostavk regresije, VIF pod ıo in toleranca nad o,2, kar pomeni, da ni težav $s$ kolineranostjo.

\section{Šesti regresijskimodel}

$\mathrm{V}$ šestem regresijskem modelu smo kot odvisno spremenljivko uporabili uspešnost uvedenih sprememb, kot neodvisne spremenljivke pa vrste sprememb.

Preglednica 57: Pojasnjenost regresijskega modela za uspešnost sprememb

\begin{tabular}{cccccc}
\multicolumn{9}{c}{ Model Summaryb } \\
Model & R & R Square & $\begin{array}{c}\text { Adjusted R } \\
\text { Square }\end{array}$ & $\begin{array}{c}\text { Std. Error of the } \\
\text { Estimate }\end{array}$ & Durbin-Watson \\
\hline I & $0,514 \mathrm{a}$ & 0,264 & 0,253 & 0,71258 & 1,698 \\
\hline
\end{tabular}

a. Predictors: (Constant), RT spremembe, IP spremembe, IT spremembe, RP spremembe

b. Dependent Variable: Uspešnost

Iz preglednice 57 je razvidno, da znaša multipla korelacija $0,5 \mathrm{I}$, in da kombinacija vseh neodvisnih spremenljivk pojasni $26,4 \%$ variabilnosti odvisne spremenljivke uspešnosti uvedenih sprememb. Vrednost Durbin- 
-Watsonovega testa znaša več kot I in manj kot 3, kar pomeni, da lahko domnevamo, da so napake neodvisne, kar je ena izmed predpostavk večkratne regresije. Sprememba $\mathrm{v} \mathrm{R}^{2}$ je statistično pomembna, kar pomeni, da se model dobro prilega podatkom in da vsaj ena izmed neodvisnih spremenljivk statistično pomembno pojasni razpršenost odvisne spremenljivke $(\mathrm{p}<0,05)$, kar je razvidno iz preglednice 58 .

Preglednica 58: ANOVA za uspešnost sprememb

\begin{tabular}{lccccc}
\multicolumn{7}{c}{ ANOVAa } & \\
\hline Model & Sum of Squares & df & Mean Square & F & Sig. \\
\hline Regression & $47,58 \mathrm{I}$ & 4 & 11,895 & 23,426 & $0,000 \mathrm{~b}$ \\
\cline { 2 - 6 } Residual & 132,528 & $26 \mathrm{I}$ & 0,508 & \\
\hline Total & 180,109 & 265 & & \\
\hline
\end{tabular}

a. Dependent Variable: Uspešnost

b. Predictors: (Constant), RT spremembe, IP spremembe, IT spremembe, RP spremembe

Preglednica 59: Regresijski koeficienti za uspešnost sprememb

\begin{tabular}{|c|c|c|c|c|c|c|c|c|}
\hline & \multicolumn{8}{|c|}{ Coefficientsa } \\
\hline & \multirow{2}{*}{ Model } & \multicolumn{2}{|c|}{$\begin{array}{l}\text { Unstandardized Coef- } \\
\text { ficients }\end{array}$} & \multirow{2}{*}{$\begin{array}{r}\begin{array}{c}\text { Standard- } \\
\text { ized Coef- } \\
\text { ficients }\end{array} \\
\text { Beta }\end{array}$} & \multirow{2}{*}{$\mathrm{t}$} & \multirow{2}{*}{ Sig. } & \multicolumn{2}{|c|}{$\begin{array}{c}\text { Collinearity } \\
\text { Statistics }\end{array}$} \\
\hline & & B & Std. Error & & & & Tolerance & VIF \\
\hline \multirow{5}{*}{ I } & (Constant) & 1,169 & 0,253 & & 4,626 & 0,000 & & \\
\hline & IT spremembe & 0,319 & 0,061 & 0,306 & 5,209 & 0,000 & 0,816 & 1,225 \\
\hline & IP spremembe & 0,359 & 0,073 & 0,316 & 4,897 & 0,000 & 0,675 & $\mathrm{I}, 48 \mathrm{I}$ \\
\hline & RP spremembe & $-0,082$ & 0,063 & $-0,088$ & $-1,308$ & 0,192 & 0,618 & I,619 \\
\hline & RT spremembe & 0,083 & 0,056 & 0,092 & 1,496 & 0,136 & 0,742 & 1,348 \\
\hline
\end{tabular}

a. Dependent Variable: Uspešnost

Preglednica 59 razkriva, da IT- in IP-spremembe pomembno pojasnijo razpršenost odvisne spremenljivke uspešnost. Če pogledamo beta-koeficiente, lahko vidimo, da imajo najvišji vpliv na uspešnost IP- in IT-spremembe, vpliv RT-sprememb je zelo majhen (vendar pozitiven), vpliv RP-sprememb pa je prav tako zelo majhen, vendar negativen. Vse vred- 
nosti VIF so pod Io in nad o,2, kar pomeni, da lahko domnevamo, da z multikolinearnostjo oz. kolinearnostjo nimamo težav.

\section{Preverjanje hipotez}

Najprej smo preverjali prve tri hipoteze, ki se nanašajo na uspešnost uvedenih sprememb. Hipoteze se glasijo:

$\mathrm{H}_{\mathrm{I}}$ : Transformacijsko vodenje je pozitivno povezano z zaznano (ocenjeno) uspešnostjo uvedenih sprememb.

$\mathrm{H}_{2}$ : Transakcijsko vodenje je prav tako pozitivno povezano z zaznano uspešnostjo uvedenih sprememb, vendar v manjši meri kot transformacijsko vodenje.

$\mathrm{H}_{3}$ : Vodenje laissez-faire je negativno povezano z zaznano uspešnostjo uvedenih sprememb.

Preglednica 60 prikazuje korelacijske koeficiente med konstrukti uspešnosti in stili vodenja. Vidimo, da obstaja statistično pomembna visoka pozitivna povezava uspešnosti s TF- in TS-vodenjem. Na podlagi tega rezultata lahko potrdimo hipotezo $\mathrm{H}_{\mathrm{I}}$.

Hipoteze $\mathrm{H}_{2}$ ne moremo potrditi v celoti. Obstaja sicer pomembna visoka povezava med uspešnostjo in TS-vodenjem, vendar ne manjša kot pri TF-vodenju, koeficienta korelacije pa sta skoraj enaka $(0,478$ in 0,479$)$. Hipotezo $\mathrm{H}_{2}$ zavrnemo.

Povezava pasivnega vodenja in uspešnosti je statistično pomembno srednje močna in negativna. Iz tega sledi, da hipotezo $\mathrm{H}_{3}$ lahko potrdimo.

Preglednica 60: Korelacijski koeficienti med konstrukti uspešnosti in vodenja

\begin{tabular}{|c|c|c|c|c|c|}
\hline & & Uspešnost & TF-vodenje & TS-vodenje & Pasivno \\
\hline \multirow{3}{*}{ Uspešnost } & Pearson Correlation & I & $0,478^{* *}$ & $0,479^{* *}$ & $-0,292^{* *}$ \\
\hline & Sig. (2-tailed) & & ০,০০০ & 0,000 & 0,000 \\
\hline & $\mathrm{N}$ & 285 & 280 & 280 & 280 \\
\hline \multirow{3}{*}{ TF-vodenje } & Pearson Correlation & $0,478^{* *}$ & I & $0,870^{* *}$ & $-0,391^{* *}$ \\
\hline & Sig. (2-tailed) & 0,000 & & 0,000 & 0,000 \\
\hline & $\mathrm{N}$ & 280 & 306 & 306 & 306 \\
\hline \multirow{3}{*}{ TS-vodenje } & Pearson Correlation & $0,479^{* *}$ & $0,870^{* *}$ & I & $-0,393^{* *}$ \\
\hline & Sig. (2-tailed) & 0,000 & 0,000 & & 0,000 \\
\hline & $\mathrm{N}$ & 280 & 306 & 306 & 306 \\
\hline
\end{tabular}




\begin{tabular}{cccccc} 
& & Uspešnost & TF-vodenje & TS-vodenje & Pasivno \\
\cline { 2 - 5 } Pasivno & Pearson Correlation & $-0,292^{* *}$ & $-0,391^{* *}$ & $-0,393^{* *}$ & I \\
\cline { 2 - 5 } & Sig. (2-tailed) & 0,000 & 0,000 & 0,000 & \\
\cline { 2 - 5 } & $\mathrm{N}$ & 280 & 306 & 306 & 306 \\
\hline
\end{tabular}

**. Correlation is significant at the 0.0 I level (2-tailed).

V nadaljevanju preverjamo hipoteze $\mathrm{H}_{4}$ do $\mathrm{H}_{7}$ :

$\mathrm{H}_{4}$ : Transakcijsko vodenje je pozitivno povezano z IT-, IP- ter s RP-spremembo.

Iz preglednice 6i je razvidno, da se TS-vodenje pozitivno in statistično pomembno povezuje z vsemi štirimi vrstami sprememb. Iz tega sledi, da hipotezo $\mathrm{H}_{4}$ lahko potrdimo.

$\mathrm{H}_{5}$ : Transformacijsko vodenje je pozitivno povezano z IT-, IP- ter s

RP-spremembo, vendar v manjšem obsegu kot transakcijsko vodenje.

Iz preglednice 6r je tudi razvidno, da je povezava med TF-vodenjem in IT-, IP-ter RP-spremembo pozitivna in statistično pomembna, vendar v večjem obsegu kot TS-vodenje. Hipoteze $\mathrm{H}_{5}$ ne potrdimo.

H6: Transakcijsko vodenje je pozitivo povezano z RT-spremembo, vendar v manjšem obsegu kot transformacijsko vodenje.

Povezava med TS-vodenjem in RT-spremembami je pozitivna, statistično značilna in manjša kot pri TF-vodenju. Vendar pa tako povezava med TS-vodenjem in RT-spremembami kot tudi povezava med TF-vodenjem in RT-spremembami sodita pod neznatno povezanost, kar pomeni, da hipotezo H6 zaradi nizke stopnje povezanosti pri obeh tipih vodenja zavrnemo. 
Preglednica 6r: Korelacijski koeficienti med konstrukti vodenja in sprememb

\begin{tabular}{|c|c|c|c|c|c|c|c|c|}
\hline & & TF-vodenje & TS-vodenje & Pasivno & $\begin{array}{l}\text { IT-spre- } \\
\text { membe }\end{array}$ & $\begin{array}{l}\text { IP-spre- } \\
\text { membe }\end{array}$ & $\begin{array}{l}\text { RP-spre- } \\
\text { membe }\end{array}$ & $\begin{array}{l}\text { RT-spre- } \\
\text { membe }\end{array}$ \\
\hline \multirow{3}{*}{ TF-vodenje } & $\begin{array}{l}\text { Pearson } \\
\text { Correlation }\end{array}$ & 1 & $870^{\circ}$ & $.391^{* *}$ &, $423^{* *}$ & $.323^{* *}$ &, $200^{\circ}$ &, $134^{\circ}$ \\
\hline & Sig. (2-tailed) & &, 000 &,$\infty 00$ &, 000 &, 000 &, 001 &, 026 \\
\hline & $\mathrm{N}$ & 306 & 306 & 306 & 272 & 280 & 279 & 273 \\
\hline \multirow{3}{*}{ TS-vodenje } & $\begin{array}{l}\text { Pearson } \\
\text { Correlation }\end{array}$ & $870^{\circ *}$ & I & $-393^{* *}$ & $409^{* *}$ & $306^{\circ}$ &, $186^{\circ}$ &, $124^{\circ}$ \\
\hline & Sig. (2-tailed) &,$\infty \circ 0$ & &, 000 &,$\infty 00$ &, 000 &, 002 &, $04 \mathrm{I}$ \\
\hline & $\mathrm{N}$ & 306 & 306 & 306 & 272 & 280 & 279 & 273 \\
\hline \multirow{3}{*}{ Pasivno } & $\begin{array}{l}\text { Pearson } \\
\text { Correlation }\end{array}$ & $.391^{*}$ & $.393^{*}$ & I &,$- 168^{* *}$ &,, $121^{\circ}$ & ,IOI &, $204^{* *}$ \\
\hline & Sig. (2-tailed) &,$\infty \circ \circ$ &, 000 & &, 005 &, 042 &, 092 &, 001 \\
\hline & $\mathrm{N}$ & 306 & 306 & 306 & 272 & 280 & 279 & 273 \\
\hline \multirow{3}{*}{$\begin{array}{l}\text { IT- } \\
\text { spremembe }\end{array}$} & $\begin{array}{l}\text { Pearson } \\
\text { Correlation }\end{array}$ &, $423^{*}$ & $409^{* *}$ &,$- 168^{* *}$ & 1 & $416^{*}$ &, $171^{* \prime}$ & ,164" \\
\hline & Sig. (2-tailed) &,$\infty \circ \circ$ &, 000 &, 005 & &, 000 &, 005 &, 007 \\
\hline & $\mathrm{N}$ & 272 & 272 & 272 & 277 & 272 & 273 & 271 \\
\hline \multirow{3}{*}{$\begin{array}{l}\text { IP- } \\
\text { spremembe }\end{array}$} & $\begin{array}{l}\text { Pearson } \\
\text { Correlation }\end{array}$ & $323^{*}$ &, $306^{*}$ & $=, 121^{*}$ &, $416^{*}$ & 1 & $475^{*}$ & , 105 \\
\hline & Sig. (2-tailed) &, 000 &, 000 &, 042 &,$\infty 00$ & &,$\infty 00$ & .082 \\
\hline & $\mathrm{N}$ & 280 & 280 & 280 & 272 & 285 & 281 & 275 \\
\hline \multirow{3}{*}{$\begin{array}{l}\text { RP. } \\
\text { spremembe }\end{array}$} & $\begin{array}{l}\text { Pearson } \\
\text { Correlation }\end{array}$ & $200 "$ & ,186" & ,101 &, $171^{* *}$ & $.475^{\circ \prime}$ & I & $463^{*}$ \\
\hline & Sig. (2-tailed) & , OOI &, 002 & .092 &, 005 &, 000 & &, 000 \\
\hline & $\mathrm{N}$ & 279 & 279 & 279 & 273 & $28 \mathrm{I}$ & 284 & 277 \\
\hline \multirow{3}{*}{$\begin{array}{l}\text { RT- } \\
\text { spremembe }\end{array}$} & $\begin{array}{l}\text { Pearson } \\
\text { Correlation }\end{array}$ &, $134^{\circ}$ &, $124^{\circ}$ &, $204^{* *}$ &, $164^{\prime \prime}$ & , 105 &, $463^{\circ}$ & 1 \\
\hline & Sig. (2-tailed) &, 026 &, 041 &, 001 & .007 &, 082 &, 000 & \\
\hline & $\mathrm{N}$ & 273 & 273 & 273 & 271 & 275 & 277 & 278 \\
\hline
\end{tabular}

**. Correlation is significant at the 0.01 level (2-tailed)

*. Correlation is significant at the 0.05 level (2-tailed).

Zadnja hipoteza se glasi:

$\mathrm{H}_{7}$ : Vodenje laissez-faire (pasivno) je negativno povezano $\mathrm{z}$ vsemi štirimi vrstami sprememb. 
Povezava pasivnega vodenja $\mathrm{z}$ IP in IT-spremembami je statistično pomembna in negativna, $z$ RP-spremembami pa nizko pozitivna, vendar statistično nepomembna. Povezava pasivnega vodenja z RT-spremembami pa je pozitivna, statistično pomembna in močnejša od povezav ostalih dveh vrst vodenja $\mathrm{z}$ RT-spremembami. Hipoteze $\mathrm{H}_{7}$ ne potrdimo, zaključimo pa lahko, da se IT-, IP- in RP spremembe povezujejo tako s transakcijskim kot s transformacijskim vodenjem (TF-vodenje nekoliko močneje kot TS-vodenje), RT-spremembe pa s pasivnim vodenjem.

\section{Primerjava rezultatov s sorodnimi raziskavami}

Rezultati raziskave so pokazali, da so v zadnjem letu v v raziskavo vključenih bolnišnicah izvajali vse štiri koncipirane vrste sprememb: inkrementalno temeljne, inkrementalno periferne, radikalno temeljne in radikalno periferne. Največji delež sprememb se je nanašal na postopne oz. inkrementalne spremembe podpornih dejavnosti, sledijo inkrementalne spremembe temeljnih dejavnosti, v manjši meri so izvajali radikalno periferne spremembe, še nekoliko manj pa radikalno temeljne. Ugotovitve podpirajo rezultate naše predhodne kvalitativne raziskave, prav tako so skladne z navajanji nekaterih teoretikov (npr. Ackerman Anderson in Anderson 200I, I I), ki pravijo, da radikalne oz. transformacijske spremembe sledijo mnogim predhodno izvedenim inkrementalnim (imenujejo jih tudi tranzicijske) spremembam. Drugače povedano, radikalne spremembe se izvajajo redkeje. Po navajanjih omenjenih avtorjev (prav tam) je pred radikalno spremembo izvedenih mnogo manjših postopnih sprememb. Pomemben razlog za ne tako pogosto uvajanje radikalno temeljnih sprememb v zdravstvu je tudi ta, da je uvajanje novih programov oz. dejavnosti povezano s financiranjem. Bolnišnice morajo nov program na začetku mnogokrat financirati iz lastnih sredstev, šele kasneje si običajno izborijo financiranje ZZZS.

Izsledki raziskave kažejo, da so vodje projektov sprememb uporabljali vse tri glavne stile vodenja: transformacijskega, transakcijskega in pasivnega. Med izvajanjem sprememb je bila izraženost transformacijskega in transakcijskega načina vodenja v povprečju skoraj enaka. LeBrasseur, Whiseell in Ojha (2002, I56) v svoji študiji ugotavljajo, kako pomembna je pri uvajanju stalnega izboljševanja kakovosti zdravstvenih storitev vključenost vršnih zdravstvenih managerjev, ki delujejo kot transformacijski vodje. Njihova spoznanja kažejo na to, da je transformacijski način vodenja najvišjih managerjev močno povezan $z$ uspešnostjo uvajanja sprememb, vezanih na stalno izboljševanje kakovosti (angl. Continuous Quality Improvement). 
Zanimiva je ugotovitev, da so vodje skoraj v enaki meri motivirali zaposlene $\mathrm{z}$ navdihovalno motivacijo (ta dimenzija TF-vodenja je dosegla najvišjo povprečno oceno) kot s pogojevanim nagrajevanjem. $Z$ navdihovanjem so vodje stimulirali navdušenje za spremembe in sodelavcem izkazovali zaupanje v njihove sposobnosti. Druga najbolj izražena dimenzija vodenja sprememb v bolnišnicah pa se je navezovala na pogojevano nagrajevanje. To je dimenzija, ki spada v transakcijsko vodenje. Če so se pri prvem načinu vodenja vodje osredotočali na spodbujanje zaposlenih, da presežejo ozkost lastnih interesov v dobrobit skupnih ciljev, pa so se s ponujanjem nagrade pri drugem načinu vodenja osredotočali na zunanjo motivacijo. Čeprav je raziskava potekala med izvajanjem varčevalnih ukrepov, ki jih je država predpisala $v$ javnem sektorju, in finančno nagrajevanje zaposlenih ni bilo mogoče, so vodje znali poiskati nematerialne vzvode za motiviranje zaposlenih. Tretja najbolj uporabljena strategija se je nanašala na intelektualno stimulacijo. $Z$ njo so vodje spodbujali svoje zaposlene $\mathrm{k}$ premisleku glede starih načinov dela ter iskanju novih poti za reševanje problemov oz. $\mathrm{k}$ inovativnosti in h kreativnosti, kar je skladno z ugotovitvami raziskav nekaterih raziskovalcev (Xirasagar, Samuels in Stoskopf 2005, 722). Tudi Hernandez (2010, 90) je ugotovil, da v uspešnih bolnišnicah pri vršnih managerjih prevladuje transformacijsko vodenje, pri katerem izstopata ravno dimenziji navdihujoča motivacija in intelektualna stimulacija.

Raziskava je pokazala, da so vodje pasivno vodenje izkazovali v manjši meri (povprečna ocena I,2 na lestvici od o do 4 ). Nekaj več je bilo vodenja z izjemami (pasivno),;njegova glavna značilnost je ta, da se vodja vključi šele takrat, ko gre kaj narobe. Raziskava je tudi pokazala, da sta se transakcijski in transformacijski način vodenja med uvajanjem sprememb izkazala za uspešna stila, medtem ko se je pasivno vodenje izkazalo za neuspešno.

Rezultati raziskave pa ne potrjujejo naše domneve, da se inkrementalno temeljne, inkrementalno periferne in radikalno periferne spremembe močneje povezujejo s transakcijskim stilom vodenja. Povedano drugače, pri vodenju omenjenih treh vrst sprememb smo predvidevali, da bi vodja lahko bil uspešen že s transakcijskim načinom vodenja. Predvidevali smo tudi, da uvajanje radikalno temeljnih sprememb v bolnišnicah zahteva razvitejše vodstvene veščine, nadgradnjo transakcijskega vodenja, ki jo na našem izbranem kontinuumu vodenja predstavlja transformacijsko vodenje. Rezultati raziskave ne potrjujejo našega konceptualnega modela, saj kažejo, da je že pri uvajanju IT- in IP-sprememb treba uporabljati oba stila, transakcijskega in transformacijskega, da so ti projekti sprememb us- 
pešno izpeljani. Že ob stalnih spremembah manjšega obsega mora vodja uporabljati oba načina vodenja. Rezultati kažejo, da je potrebno uporabljati celo nekoliko več transformacijskega načina vodenja.

Presenetljiva ugotovitev raziskave pa je povezana z uvajanjem radikalnih sprememb. Rezultati so pokazali, da se radikalno temeljne spremembe v bolnišnicah najbolj povezujejo s pasivnim vodenjem, v precej manjši meri pa s transformacijskim in transakcijskim vodenjem. Manjšo povezanost stilov smo na sliki 25 označili z oklepaji. Radikalno periferne spremembe pa se povezujejo $s$ transformacijskim in transakcijskim vodenjem. Pri radikalno perifernih spremembah se rezultati korelacijske analize razlikujejo od regresijskih koeficientov, zato rezultate omenjene regresijske analize zaradi možne multikolinearnosti interpretiramo previdno. Omenjena multikolinearnost je eden izmed možnih razlogov za razliko med rezultati regresije in korelacije. Zato pri RP-spremembah raje upoštevamo rezultate korelacijske analize. Konceptualni teoretični model smo tako prilagodili izsledkom raziskave in ga prikazujemo na sliki 23.

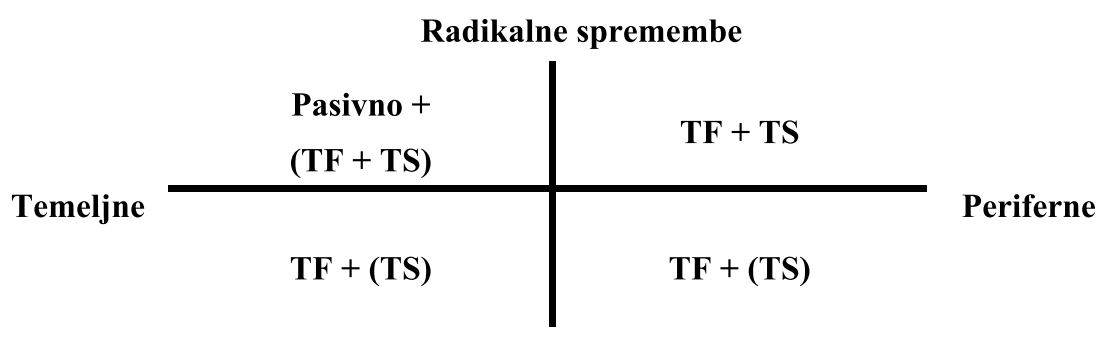

\section{Inkrementalne spremembe}

Slika 23: Ugotovljeni stili vodenja glede na vrsto spremembe

Možna razlaga za povezovanje pasivnega vodenja $\mathrm{z}$ uvajanjem radikalno temeljnih sprememb je, da v bolnišnicah delujejo visoko usposobljeni delavci, ki dajejo razvoju svoje stroke velik poudarek. Radikalno temeljne spremembe pomenijo spremembe temeljnih programov oddelkov ali celotne bolnišnice v medicinski stroki. Dogaja se, da visoko usposobljeni timi in posamezniki ne potrebujejo posebnega usmerjanja oz. vodenja. Vodijo se sami. Vodje jim pustijo popolno avtonomijo na njihovih strokovnih področjih. Še posebej sta avtonomija in osebna odgovornost pomembni značilnosti zdravniškega poklica (LeTourneau in Fleischauer I999, I2). Vendar to istočasno pomeni tudi odmik vodij od odgovornosti, kar lahko na koncu vodi v neuspešnost teh sprememb. 
Uvajanje radikalno perifernih sprememb zahteva premišljeno prilagajanje stilov, transformacijskega in transakcijskega. Radikalne spremembe perifernih dejavnosti pomenijo temeljite spremembe $\mathrm{v}$ izrazito profiliranih dejavnostih, npr. informatiki.

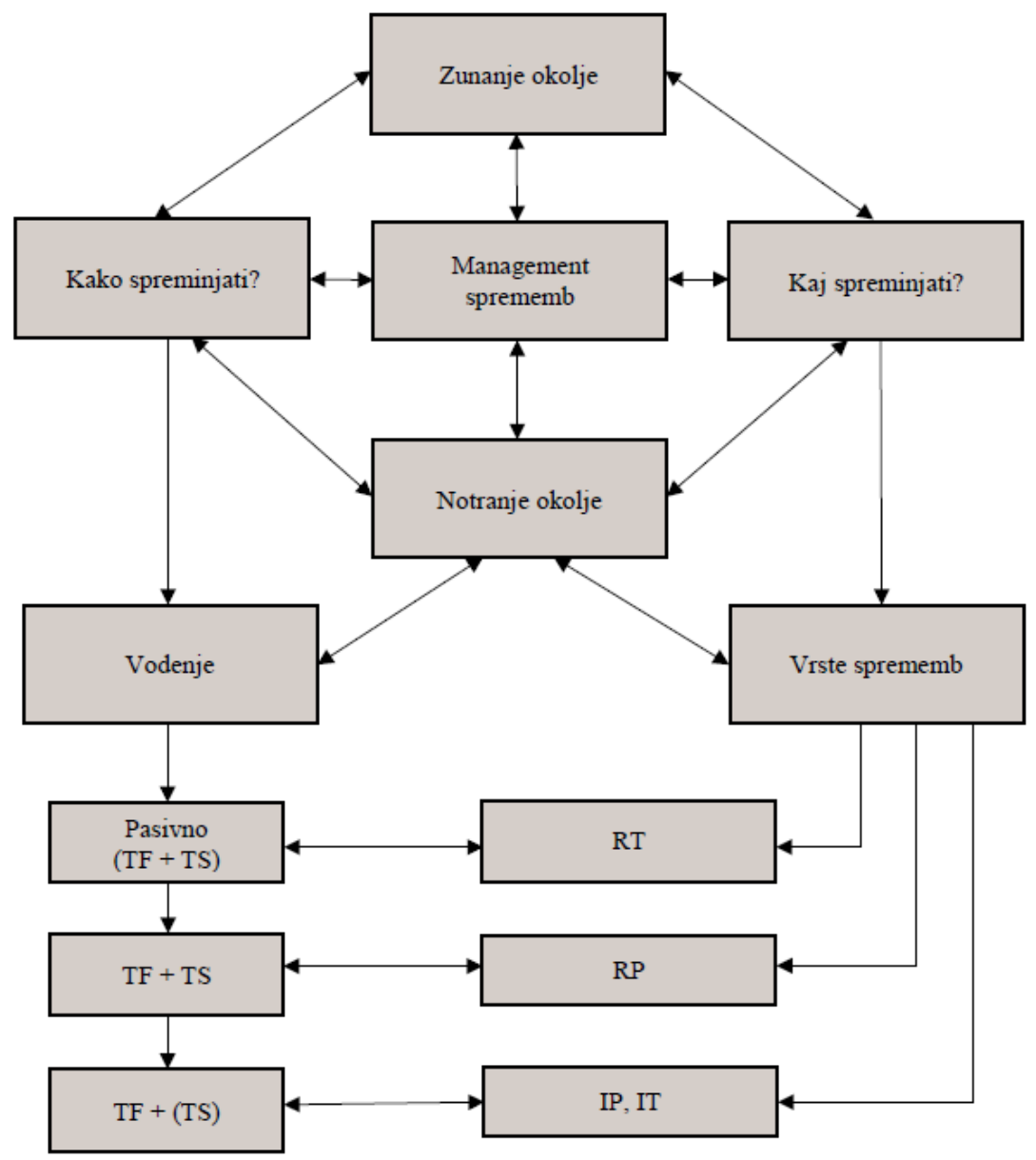

Slika 24: Vodenje sprememb v bolnišnicah vezano na ugotovitve raziskave

Slika 24 prikazuje shematski model dejanskega vodenja posameznih vrst sprememb v bolnišnicah.

Glede na izsledke raziskave o zaznani uspešnosti uvedenih sprememb smo spremenili konceptualni model izvajanja sprememb v bolnišnicah. $\mathrm{V}$ okviru procesa spreminjanja smo se osredotočili na tri stile vodenja, za ka- 
tere je raziskava pokazala, da se statistično značilno povezujejo s posameznimi vrstami sprememb. TS- in TF-vodenje sta uspešna pristopa, medtem ko pasivno vodenje ne prispeva $\mathrm{k}$ uspešnosti uvedenih sprememb. Raziskava je pokazala, da so bile IT- in IP-spremembe uspešne, RT- in $\mathrm{RP}$-spremembe pa neuspešne. Menimo, da so med drugim razlogi za neuspešnost radikalnih sprememb $\mathrm{v}$ pretežno izraženem pasivnem načinu vodenja $\mathrm{RT}$-sprememb, pri RP-spremembah pa v premajhni izraženosti transformacijskega vodenja v primerjavi s TS-vodenjem. Menimo, da bi pri uvajanju obeh vrst radikalnih sprememb moralo v večji meri prevladati TF-vodenje nad TS-vodenjem. Izogibati pa bi se morali pasivnemu vodenju, kajti nevodenje oz. prepuščanje odgovornosti za uvajanje RT-sprememb ne vodi $k$ uspehu. Znano je tudi, da transformacijsko vodenje ljudi usmerja $\mathrm{k}$ višjim ciljem oz. idealom, jih intelektualno stimulira in motivira ter je še posebej primerno za uvajanje korenitih sprememb. Predlagamo alternativni model, ki ga prikazuje slika 25.

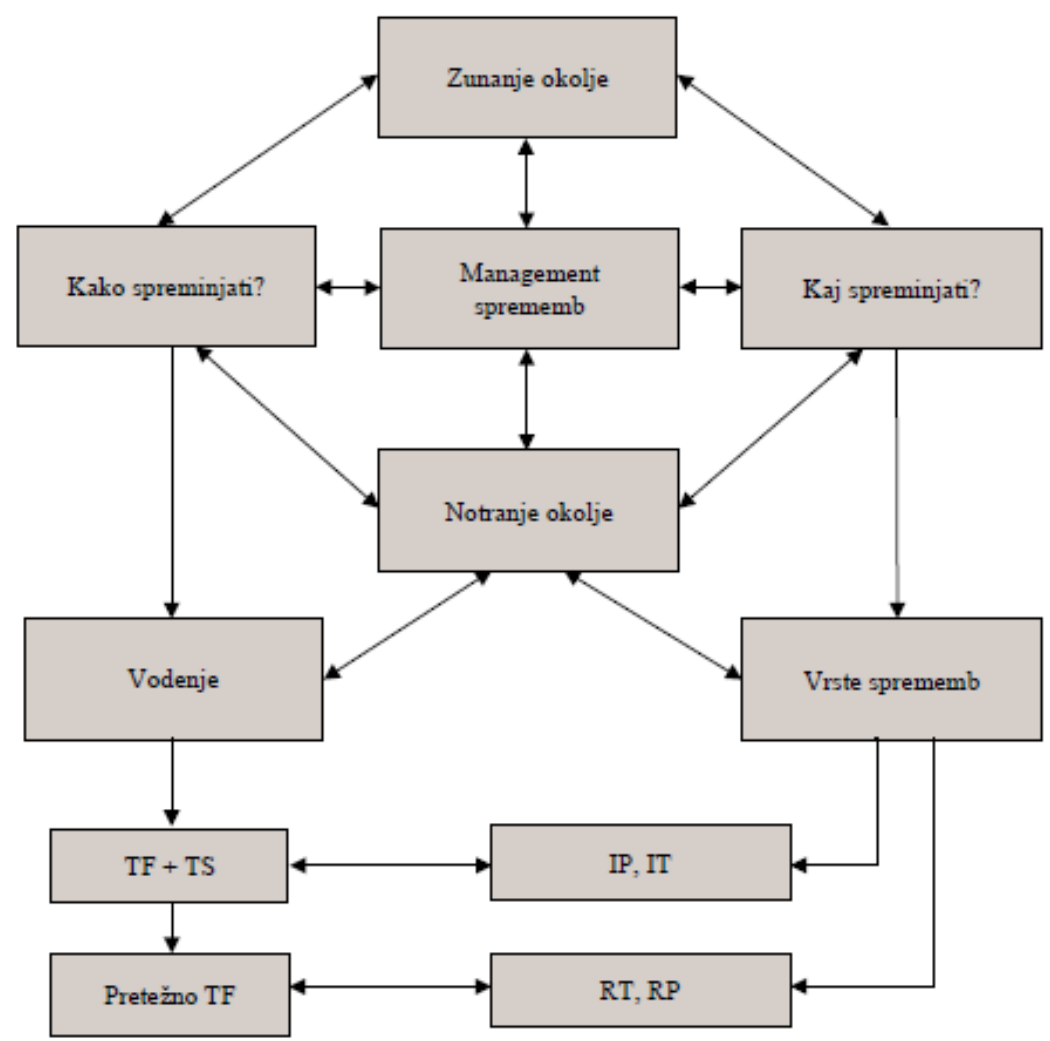

Slika 25: Alternativni model vodenja sprememb v bolnišnicah 


\section{Sklep}

Živimo v konstantno spreminjajočem se globalnem poslovnem okolju. Podatek, da v organizacijah uspe le 30 odstotkov začetih sprememb, je prav zaskrbljujoč, pa vendar ne presenetljiv, če upoštevamo, da statistike kažejo, da organizacijskih sprememb ne podpira 33 odstotkov vodstvenega kadra in 39 odstotkov ostalih zaposlenih. Delovanje in spreminjanje zdravstvenih organizacij je zaradi storitev, ki jih izvajajo (govora je o pomembni vrednoti, tj. zdravju ljudi) še toliko občutljivejše in tudi zahtevnejše. Zato ne preseneča stalno zanimanje raziskovalcev za raziskovanje omenjene problematike in snovanje novih metod uvajanja sprememb. Raziskave in literaturo o organizacijskih spremembah bi lahko razvrstili v štiri glavna področja, ki se nanašajo na: (I) vrste sprememb, (2) aktivatorje oz. pospeševalce sprememb, (3) metode oz. načine spreminjanja in (4) rezultate sprememb (Al-Haddad in Kotnour 2015, 24I). Tudi sami na podlagi opravljene raziskave in preučitve literature s področja managementa sprememb predlagamo integriran model vodenja sprememb v bolnišnicah, ki povezuje vrste sprememb v bolnišnicah $s$ pristopi $\mathrm{k}$ vodenju posamezne vrste sprememb. Primerno izhodišče za okolje bolnišnic nam je predstavljala osnovna tipizacija sprememb po Penningtonu $(2003,6), \mathrm{ki}$ spremembe deli na radikalne in inkrementalne. Obe vrsti sprememb pa obravnava $\mathrm{v}$ sklopu temeljnih in perifernih dejavnosti. Na podlagi omenjenega smo koncipirali štiri vrste sprememb: radikalno temeljne, radikalno periferne, inkrementalno temeljne in inkrementalno periferne. Izsledki predhodno izvedene kvalitativne raziskave $\mathrm{v}$ bolnišnicah so nam prinesli osnovne značilnosti posamezne vrste sprememb, ki smo jih nato operacionalizirali v nadaljevanju raziskave. 
Spreminjanje $\mathrm{v}$ zdravstvu, predvsem radikalno (kot npr. posledica združevanja bolnišnic), je še posebej težko, kar v svojih študijah ugotavljajo nekateri avtorji (npr. Bazzoli idr. 2004, 213). Potreben je čas, da ljudje »kupijo « spremembo in pridobijo zaupanje vanjo. Management v zdravstvu se zato sooča z odpori in njihovo premagovanje je težko ter zamudno delo. Morda gre tudi temu pripisati dejstvo, da prav veliko korenitih sprememb v preučevanih bolnišnicah niso izvajali. V pretežnem delu so bile spremembe posledica uvajanja oz. izvajanja sistemov kakovosti.

Podobno kot Barnett in Caroll (1995, v Bazzoli idr. 200I, 252) smo pri razvoju modela upoštevali tako procesni kakor tudi vsebinski vidik spreminjanja. Avtorja (prav tam) sta namreč identificirala dve glavni dimenziji organizacijske spremembe: vsebino (kaj) in proces (kako). Vsebina predstavlja materijo organizacijske spremembe, kot so npr. spremembe v strateški orientiranosti in strukturah znotraj organizacijskega okolja. Proces spreminjanja pa se osredotoča na niz nujnih korakov oz. aktivnosti, ki podpirajo spreminjanje znotraj organizacije in naj bi jih management izvedel tekom procesa spreminjanja.

$\mathrm{V}$ predlaganem modelu smo zato želeli povezati vsebinski del spremembe s procesnim delom. Materijo smo koncipirali v štirih vrstah sprememb, ki so radikalno temeljne, radikalno periferne, inkrementalno temeljne in inkrementalno periferne spremembe. Kot radikalno temeljne smo identificirali naslednje: korenite spremembe procesov dela v temeljnih dejavnostih bolnišnic; popolno reorganizacijo bolnišničnih oddelkov, ki opravljajo temeljno dejavnost; spremembe temeljnih programov zdravljenja in diagnosticiranja, ki bistveno vplivajo na utečene načine dela; uvedbo nove temeljne dejavnosti posameznega oddelka s popolno prekinitvijo stare dejavnosti in uvedbo nove temeljne dejavnosti bolnišnice.

Med inkrementalne spremembe $\mathrm{v}$ bolnišnicah smo uvrstili stalno izboljševanje kakovosti, postopkov dela, optimizacijo delovnih procesov, uvedbo novih metod zdravljenja ali novih programov, ki pa niso predstavljali velikih pretresov.

Pri procesnem vidiku smo se osredotočili na vodenje in raziskali stile vodenja projektnih vodij med izvajanjem sprememb. V svojem modelu smo tako integrirali oba vidika. Rezultati raziskave so pokazali, da management uvajanje radikalnih sprememb $\mathrm{v}$ bolnišnicah vodi na pasiven način. Uvajanje prepušča strokovnjakom, vodja poseže le, če gredo stvari narobe. Pri inkrementalnih spremembah vodje uporabljajo transakcijski in transformacijski stil vodenja, kar ocenjujemo kot dobro, saj je znano, da transformacijski stil vodenja prispeva $k$ večjemu zadovoljstvu zaposle- 
nih ter motivira zaposlene, da so pripravljeni v spremembe vložiti več truda in delovnega napora (Xirasagar, Samuels in Stoskopf 2005, 728), prav tako povečuje pripadnost zaposlenih (Houghton in Christian 2005, 74).

Kvalitativna raziskava je glede procesa spreminjanja pokazala, da vodstva bolnišnic $\mathrm{v}$ večini primerov $\mathrm{k}$ spremembam pristopajo načrtno. $\mathrm{Z}$ zaposlenimi in $\mathrm{v}$ spremembe vključenimi skupinami opravljajo številne razgovore. Prav tako se izvajajo tudi potrebna izobraževanja in druge priprave zaposlenih na uvajanje sprememb. Informiranja glede sprememb je torej veliko, pa vendar so zaposleni v nekaterih bolnišnicah še vedno povedali, da je tega premalo. Se je pa izkazalo, da so v bolnišnicah, v katerih so bila vodstva vztrajna, spremembe tudi uspešno vpeljali. Kot je pokazala kvalitativna raziskava, spremembe največkrat sprožijo zunanji dejavniki (ministrstvo ali ZZZS), s katerimi pa se zaposleni v bolnišnicah, še posebej zdravniki, velikokrat ne strinjajo oz. se sprašujejo o smislu tovrstnih sprememb. Zaposlene je treba za spremembe prepričevati in motivirati, kar pa je ob percepciji nesmisla težko storiti z direktivnim pristopom. Verjetno je tudi to razlog, da sta se ob uvajanju manjših inkrementalnih sprememb oba stila, transformacijski in transakcijski, izkazala kot uspešna in primerna. Raziskava pa je pokazala, da pasivni način vodenja ni uspešen, čeprav je močno prisoten ob uvajanju obeh vrst radikalnih sprememb. Mnogo vodij, vključenih v temeljne procese, razvoju lastnih vodstvenih veščin ne pripisuje velikega pomena. Teh veščin zelo primanjkuje predvsem pri zdravstvenih vodjih. Ti se zelo pogosto in radi izobražujejo o vsebinah, ki so vezane na njihovo osnovno stroko, zelo neradi pa se udeležujejo izobraževanj, ki so vezana na druga področja, kot so vodenje, management, organizacija, komunikacija idr.

Pričujoča raziskava prinaša za prakso v bolnišnicah in tudi širše nekaj zelo pomembnih spoznanj. Pri uvajanju inkrementalno temeljnih in inkrementalno perifernih sprememb morajo vodje razviti veščine transakcijskega kot tudi transformacijskega vodenja. Znano je, da se vodstvenih veščin lahko naučimo oz. priučimo. Osnovno znanje je možno pridobiti v mnogih izobraževalnih programih, ki jih ponujajo različni ponudniki izobraževalnih storitev. Nekateri avtorji pa predlagajo individualni coaching (Kurup in Pankajam 2000, 63), s katerim vodje dobijo poglobljen vpogled vase in s spremembami na sebi razvijajo univerzalne atribute vodenja, kot so: biti pozitivno naravnan, opogumljajoč, biti dober motivator in graditi zaupanje (Leong in Fischer 201 I, 164).

Raziskava je prišla še do enega pomembnega spoznanja, in sicer da pri uvajanju radikalno temeljnih sprememb vodje uporabljajo pasivni način vodenja. Ugotovitve raziskave kažejo, da ta način vodenja ni uspe- 
šen. Zato predlagamo, da ga nadomestijo s transformacijskim vodenjem, za katerega je znano, da se povezuje $\mathrm{z}$ radikalnimi spremembami (transformacijo) tako na ravni posameznika kot na ravni organizacije. Čeprav radikalno spreminjanje $\mathrm{v}$ bolnišnicah ni ravno pogost pojav, ima lahko neuspešno uvajanje teh sprememb večje negativne posledice. Vodstva bolnišnic bi se morala tega zavedati in pozorno določati, koga bodo zadolžila za vodenje radikalno temeljnih pa tudi radikalno perifernih sprememb ter kako se jih bodo lotevala. Glede na ugotovitve raziskave odsvetujemo pasivno vodenje, ki vključuje vodenje laissez-faire (oblika nevodenja) ter pasivni management $\mathrm{z}$ izjemami, pri katerem se vodja ne vključuje $\mathrm{v}$ sam proces sprememb. Posreduje le, ko gre nekaj narobe.

Kvalitativna raziskava je $\mathrm{v}$ nekaterih bolnišnicah razkrila slabo poznavanje managementa sprememb. Predlagamo, da si vodje sprememb v bolnišnicah pridobijo tudi osnovna znanja s tega področja. Poznavanje posameznih faz oz. korakov v procesu spreminjanja jim bo bistveno olajšalo delo in prispevalo $k$ večji uspešnosti uvedenih sprememb. Tovrstno izobraževanje pa je primerno dopolniti še z delavnicami, kjer lahko zaposleni gradijo občutek pripadnosti organizaciji in imajo možnost bolje razumeti način delovanja in smernice razvoja organizacijskega okolja. Nedavna študija je namreč pokazala, da le 40 odstotkov zaposlenih v podjetjih pozna cilje svojega podjetja, sprejete strategije in taktike. Te poslovne informacije pa predstavljajo le vrh ledene gore; druge pomembne podrobnosti, kot so zaznave, prepričanja, vrednote in skupne predpostavke so veliko bolj prekrite in zato manj prepoznavne, obenem pa ključnega pomena za uspešnost organizacije. Čeprav je navedeni odstotek lahko višji v bolišnicah in zaradi same narave dela tudi verjetno je, pa ostaja dejstvo, da so temeljne vrednote in prepričanja velikokrat nekakšna tabu tema, o kateri se zaposleni v bolnišnicah ne pogovarjajo.

$S$ predlaganim konceptualnim modelom in $\mathrm{z}$ na podlagi rezultatov raziskave oblikovanim alternativnim modelom vodenja sprememb $\mathrm{v}$ bolnišnicah smo lahko odgovorili na del zastavljenih vprašanj. Tudi sama raziskava je odprla še nekaj dodatnih vprašanj. V prihodnosti, z razvojem vodenja oz. vodstvenih pristopov v bolnišnicah, bi bilo treba preučiti, kako je $\mathrm{z}$ vodenjem radikalno temeljnih in radikalno perifernih sprememb.

$\mathrm{V}$ raziskavo je bilo vključenih osem bolnišnic. Anketni vprašalnik je vrnilo 294 respondentov. Izide raziskave je možno posplošiti na vse slovenske bolnišnice. Ker pa je radikalnih sprememb v bolnišnicah malo, bi bilo smiselno raziskati vodenje teh sprememb na večjem vzorcu. Tudi z vidika potrditve 9 -faktorskega modela vodstvenih stilov (česar v raziska- 
vi nismo delali, analizirali smo 3 -faktorski model) bi bilo treba raziskavo opraviti na večjem vzorcu. Koncipiran alternativni model, ki ga predstavlja slika 25, bi bilo treba še enkrat empirično preveriti, predvsem v delu vodenja radikalnih sprememb.

Podobno raziskavo bi lahko naredili tudi za primarni nivo zdravstva in primerjali rezultate. Ker je bila v raziskavo vključena samo ena specialna bolnišnica, iz katere nismo prejeli velikega števila izpolnjenih vprašalnikov, ni bilo smiselno delati primerjave med posameznimi vrstami bolnišnic. Zanimivo bi bilo izvesti raziskavo v razvitejših državah in primerjati rezultate. da:

Naša raziskava je temeljila na dveh osnovnih predpostavkah, in sicer

- akreditacija bolnišnic ali/in vpeljan sistem kakovosti predstavlja stalno skrb za nenehno izboljševanje vseh procesov dela znotraj

bolnišnic in $s$ tem osredotočenost na stalno uva-janje sprememb;

- so udeleženci v raziskavi odgovarjali kar se da objektivno.

Vsaka raziskava se srečuje z omejitvami. V nadaljevanju izpostavljamo glavne omejitve naše raziskave.

- Do spoznanj smo prišli na osnovi podatkov, ki so bili zbrani znotraj specifičnega časovnega intervala, in so zato reprezentativna znotraj omenjenega intervala.

- Dinamična narava vodenja ne more biti pokrita samo z enim merskim instrumentom, ki meri stile vodenja, ne osvetli pa drugih dejavnikov v procesu vodenja, situacijskih dejav-nikov in karakteristik oz. značilnosti vodenih.

- Uporaba kvotnega vzorca v drugi fazi dvostopenjskega vzorčenja pri kvantitativnem delu raziskave lahko pomeni omejitev statističnega sklepanja iz vzorca na populacijo, kar pa smo poskušali eliminirati z vzorčenjem, pri katerem smo vključili več kot polovico vseh zaposlenih $\mathrm{v}$ preučevanih bolnišnicah.

Kljub omejitvam pa raziskava daje vpogled v vrsto izvajanih sprememb v slovenskih bolnišnicah in njihovo vodenje ter tako dopolnjuje sicer skromno slovensko literaturo s tega področja. 



\section{Literatura}

Ackerman Anderson, Linda, in Dean Anderson. 2001. The Change Leader's Roadmap. San Francisco: Jossey-Bass.

Adair, John. 1998. Effective Leadership. How to Develop Leadership Skills. London: Pan Books.

Adizes, Ichak. 1996. Obvladovanje sprememb. Ljubljana: Gospodarski vestnik.

Al-Haddad, Serina, in Timothy Kotnour. 2015. »Integrating the Organizational Change Literature: A Model for Successful Change.« Journal of Organizational Change Management 28 (2): 234-62.

Alimo-Metcalfe, Beverly, in John Alban-Metcalfe. 2005. »Leadership: Time for a New Direction? «eadership I (I): 5I-7I.

Alvesson, Mats, in Stanley Deetz. 2000. Doing Critical Management Research. London: Sage Publications.

Andrews, Jane, Helen Cameron in Margaret Harris. 2008. »All Change? Managers' Experience of Organizational Change in Theory and Practice.«Journal of Organizational Change Management 2 I (3): 300-3 I 4.

Angel-Sveda, Andrea. 2012. »Organizational Change. Basic Theoretical Approaches.« The Public Administration and Social Policies Review 2 (9): 74-8I.

Ansoff, Igor. 1981. Strategic Management. London: MacMillan.

Arnett, Gayle. 2010. \Cost Reduction in Health Systems: Mission Critical.« Frontiers of Health Services Management 27 (2): 37-40. 
Avolio, Bruce J., in Bernard Bass. 1998. »You Can Drag a Horse to Water, But You Can't Make It Drink: Except When It's Thirsty.«Journal of Leadership Studies 4 (I): I-I7.

Avolio, Bruce J., in William L. Gardner. 2005. »Authentic Leadership Development: Getting to the Root of Positive Forms of Leadership.« The Leadersip Quarterly I6 (3): 315-338.

Bass, Bernard M. 1990. Handbook of Leadership. Theory, Research and Managerial Applications. New York: The Free Press.

Bass, Bernard M., in Bruce J. Avolio. 1995. Multifactor Leadership Questionnaire. Palo Alto: Mind Garden Inc.

Bassey, Michael. 1999. Case Study Research in Educational Settings. Buckingham: Open University Press.

Barnett, William P., in Glenn R. Carroll. 1995. »Modeling Internal Organizational Change.« Annual Review of Sociology 21: 217-236.

Bazzoli, Gloria J., Linda Dynan, Lawton R. Burns in Clarence Yap. 2004. »Two Decades of Organizational Change in Health Care: What Have We Learned? « Medical Care Research and Review 6I (3): 247-33I.

Beer, Michael, in Nitin Nohria. 2000. »Cracking the Code of Change.« Harvard Business Review 78 (3): 133-4I.

Belbin, Meredith R. 1993. Management Teams - Why They Succed or Fail. Oxford: Butterworth - Heinemann.

Bennet, Roger. 1997. Organizational Behaviour. London: Pitman Publishing.

Bennis, Warren, in Burt Nanus. 2005. Leaders: Strategies for Taking Charge, 2nd ed. New York: HarperCollins Publishers Inc.

Betbeze, Philip. 2015. »Leading Through Change.« HealthLeaders Magazine March 2015: 37-41. http://healthleadermedia.com.

Biloslavo, Roberto. 1999. Metode in modeli za management. Koper: Fakulteta za management.

Biloslavo, Roberto. 20ı $\gg$. Moč, avtoriteta in management.« V Avtoriteta in vodenje: avtoriteta v vodenju, ur. Anita Trnavčevič, 73-86. Koper: Fakulteta za management.

Blake, Robert R., in Jane S. Mouton. 1985. The Managerial Grid: The Key to Leadership Excellence. Houston: Gulf Publishing Company.

Blanchard, Ken, in Terry Waghorn. 1996. Misija mogoče. Kako ustvariti vrhunsko organizacijo, dokler je še čas. Ljubljana Taxus. 
Bola Natek, Aleksandra. 20I4. Kompetence zdravnikov - vodij in uvajanje sodobnih oblik organiziranosti. Magistrska naloga, Univerza na Primorskem, Fakulteta za management.

Bouckenooghe, Dave, Geert Devos in Herman Van den Broeck. 2009. »Organizational Change Questionnaire - Climate of Change, Processes, and Readiness: Development of a New Instrument.« The Journal of Psychology I 43 (6): 559-99.

Bowen, Deborah J. 2015. \5 Competencies for CEOs. In the New Era of Health Care, Hospital Boards Must Consider a Different Kind of Leadership Style.« Trustee 68 (I0): 34-35.

Branagan, Linda G. 20ıо. »An Exploratory Investigation of Physician Champions for Hospital-based Information.« PhD diss., Alliant International University.

Branden, Nathaniel. 2000. Samozavestno vodenje: kako moćni ljudje ustvarjajo učinkovite organizacije. Ljubljana: Inštitut za razvijanje osebne kakovosti.

Brown, Stephen. 2012. \Managing Change. How to Achieve Effective, Large-scale, Long-term Change in a UK Setting.« https://cdelondon.files.wordpress.com/20II/I I/managing_change

Budak, Fatih, in Ahmet Kar. 2014. »The Importance of Strategic Leadership in Healthcare Management.«IIB International Refereed Academic Social Sciences Journal 5 (15): I55-7 I.

Bukovec, Boris. 2005. \Pomen voditeljstva v procesu obvladovanja sprememb.« Organizacija 38 (I): 39-45. Kranj: Moderna organizacija.

Bukovec, Boris. 2009. Nova paradigma obvladovanja sprememb. Nova Gorica: Fakulteta za uporabne družbene študije.

Bulc, Violeta. 2006. Ritmi poslovne evolucije. Sistemi, orodja in izkušnje za viharna razmišljanja. Ljubljana: GV.

Burke, Wyatt Warner. 2002. Organization Change. Theory and Practice. London, Thousand Oaks, New Delhi: Sage Publications.

Burke, Wyatt Warner, in George H. Litwin. I992. »A Casual Model of Organizational Performance and Change.«Journal of Management i 8 (3): $532-45$.

Burns, James MacGregor. 1978. Leadership. New York: Harper \& Row.

Caldwell, Chip, Greg Butler and Nancy Poston. 2010. »Cost Reduction in Health Systems: Lessons from an Analysis of \$200 Million Saved by Top-Performing Organizations. « Frontiers of Health Services Management $27(2): 3-17$. 
Carnall, Colin. 2007. Managing Change in Organizations, 5th ed. Harlow: Pearson Education Limited.

Chapman, Ann L. N., David Johnson in Karen Kilner. 2014. »Leadership Styles Used by Senior Medical Leaders. Patterns, Influences and Implications for Leadership Development.« Leadership in Health Services 27 (4): $283-98$.

Charan, Ram. 2009. Leadership in the Era of Economic Uncertainty: The New Rules for Getting the Right Things Done in Diffcult Times. New York: McGraw-Hill.

Chrusciel, Donald. 2008. »What Motivates the Significant Strategic Change Champion(s)? « Journal of Organizational Change Management 2 I (2): $148-60$.

Cimerman, Mitja, Sandi Jerman, Roman Klarič, Borut Ložar in Zoran Sušanj. 2003. Manager prvi med enakimi. Ljubljana: GV Založba.

Collison, Chris, in Geoff Parcell. 2002. Učimo se leteti. Priročnik za upravljanje znanja. Ljubljana: GV Založba.

Connor, Daryl R. 1995. Managing at the Speed of Change: How Resilient Managers Succeed and Prosper Where Others Fail. New York: Villard Books.

Covey, Stephen R. 2000. Načela uspeŕnega vodenja. Ljubljana: Mladinska knjiga.

Černetič, Metod. I997. Poglavja iz sociologije organizacij. Kranj: Moderna organizacija.

DaCosta, Joanna. 2012. »Leadership Models for Healthcare Improvement.«British Journal for Healthcare Management I 8 (I I): 575-80.

Dessler, Gary. 2001. Management: Leading People and Organizations in the 2Ist Century. New Yersey: Prentice Hall.

Dimovski, Vlado, Sandra Penger in Judita Peterlin. 2009. Avtentično vodenje $v$ učeči se organizaciji. Ljubljana: Planet GV.

Dimovski, Vlado, Sandra Penger, Miha Škerlavaj in Jana Žnidaršič. 2005. Učeča se organizacija. Ljubljana: GV Založba.

Doppler, Klaus, in Christoph Lauterburg. 2008. Change Management. Frankfurt ob Majni: Campus Verlag.

Drucker, Peter. 1999. Leadership Challenges for the 2Ist Century. Oxford: Heinemann.

Drucker, Peter. 2004. O managementu. Ljubljana: GV Založba.

Dubrin, Andrew. 2004. Leadership. New York, Boston: Houghton Mifflin Company. 
Dulewicz, Victor, in Malcolm Higgs. 2005. »Assessing Leadership Styles and Organisational Context.« Journal of Managerial Pshychology 20 (2): $105-23$.

Easterby-Smith, Mark, Richard Thorpe in Andy Lowe. 2005. Raziskovanjev managementu. Koper: Fakulteta za management.

Elmuti, Dean, William Minnis in Michael Abebe. 2005. »Does Education Have a Role in Developing Leadership Skills?« Management Decision 43 (7/8): IOI 8-31.

Evans, Roger, in Peter Russell. 1992. Ustvarjalni manager. Ljubljana: Alpha Center.

Everard, Bertie, in Geoffrey Morris. 1996. Uspešno vodenje. Ljubljana: Zavod Republike Slovenije za šolstvo.

Fagerstr $\bigotimes \mathrm{m}$, Lisbeth, in Susanne Salmela. 2010. »Leading Change: A Challenge for Leaders in Nordic Health Care.«Journal of Nursing Management I 8 (5): 613-17.

Farrukh, Muhammad, in Abdul Waheed. 2015. »Learning Organization and Competitive Advantage - An Integrated Approach.« Journal of Asian Business Strategy s (4): 73-79.

Ferjan, Marko. 1999. »Učeča se organizacija.«V Sodobne oblike in pristopi pri organiziranju podjetij in drugih organizacij, ur. Jure Kovač, I19-36. Kranj: Moderna organizacija.

Ferlie, Ewan B., in Stephen M. Shortell. 200I. »Improving the Quality of Healthcare in the United Kingdom and United States: A Framework for Change.« The Milbank Quarterly 79 (2): 28I-315.

Fickenscher, Kevin, in Michael Bakerman. 20I . »Change Management in Health Care IT.«Phyisician Executive 37 (2): 64-67.

Fiedler, F. E. 1967. A Theory of Leadership Effectiveness. New York: McGraw-Hill.

Flere, Sergej. 200o. Sociološka metodologija (Temelji družboslovnega raziskovanja). Maribor: Pedagoška fakulteta.

Fraser, Sherry. 201 4. »Authentic Leadership in Higher Education: Influencing the Development of Future Leaders.« PhD diss., St. John Fisher College.

French, John, in Bertram Raven. 1959. The Bases of Social Power. Ann Arbor: University of Michigan, Institute for Social Research, I50-I67.

Fullan, Michael. 2001. Leading in a Culture of Change. San Francisco: Jossey-Bass. 
Gandossy, Robert P., in Nidhi Verma. 2009. Building Leadership Capability to Drive Change. Leader to Leader, 51: 40-46.

Georgiades, Nick, in Richard Macdonell. 1998. Leadeship for Competitive Advantage. Chichester: John Wiley \& Sons Ltd.

Gil, Francisco, Ramon Rico, Carlos M. Alcover in Angel Barrasa. 2005. »Change-Oriented Leadership, Satisfaction and Performance in Work Groups. Effects of Team Climate and Group Potency.«Journal of Managerial Psychology 20 (3/4): 3 $12-28$.

Gilster, Susan D. 2002. »Leadership: Key to Creating a Caring Culture.« American Journal of Alzheimer's Disease and Other Dementias 17 (4): 232-36.

Goleman, Daniel. 2oro. Socialna inteligenca. Nova veda o odnosih med ljudmi. Ljubljana: Mladinska knjiga.

Goleman, Daniel, Richard Boyatzis in Annie McKee. 2002. Prvinsko vodenje. Ljubljana: GV Založba.

Golembiewski, Robert, Keith Billingsley in Samuel Yeager. 1976. »Measuring Change and Persistence in Human Affairs: Types of Change Generated by OD Designs.«Journal of Applied Behavioral Science I 2 (2): I33I57.

Goodwin, Neil. 2006. Leadership in Health-care: A European Perspective. London, New York: Routledge.

Gorišek, Karmen, in Gorazd Tratnik. 2003. Sprostitev moči zaposlenih - priložnost za poslovni uspeh. Ljubljana: Slovenski institut za kakovost in meroslovje.

Gračner, Ana. 2014. »Management sprememb in uspešno uvajanje kulture varnosti bolnikov: študija primera slovenske bolnišnice.« Doktorska disertacija, Univerza v Ljubljani.

Griffith-Cooper, Barber, in Karyl King. 2007. »The Partnership between Project Management and Organizational Change: Integrating Change Management with Change Leadership.« Performance Improvement 46 (I): I 4-20.

Gyllstrom, Elizabeth, Kimberly Gearin, Renee Frauendienst, Julie Myhre, Michelle Larson in William Riley. 2015. »Local Health Department Factors Associated With Performance in the Successful Implementation of Community-Based Strategies: A Mixed-Methods Approach.« American Journal of Public Health Ios (2): 3 I I-I 7.

Hamrefors, Sven. 201 . »Communicative Leadership.«Journal of Communication Management I 4 (2): I 4I-52. 
Hansen, Marc Victor, in Joe Batten. 1998. Mojster motiviranja. Skrivnosti navdihujočega vodenja. Bled: Vernar consulting.

Harigopal, K. 2006. Management of Organizational Change. Leveraging Transformation. 2nd Edition. New Delhi, Thousand Oaks, London: Sage Publications.

Hernandez, Beverly J. D. 20 Io. »The Relationship between Leadership Styles and Performance Success in Hospitals.« PhD diss., Walden University.

Hersey, Paul, in Kenneth H. Blanchard. 1993. Management of Organizational Behaviour, 6th ed. New Jersey: Prentice Hall.

Hewitt-Taylor, Jaqui. 2013. »Planning Successful Change Incorporating Processes and People.« Nursing Standard 27 (38): 35-40.

Hockin, Ronald S. 2007. »Integrating Leadership Activities with Organizational Survivability: toward a Theory of Healthcare Transformation.« PhD diss., Capella University.

Hočevar, Marko, Marko Jaklič in Hugo Zagoršek. 2003. Ustvarjanje uspešnega podjetja. Akcijski pristop $k$ strateškemu razmišljanju, vodenju in nadziranju. Ljubljana: GV Založba.

Holt, Daniel T., Dennis R. Self, Alfred E. Thal, Jr. in Steven W. Lo. 2003. »Facilitating Organizational Change: A Test of Leadership Strategies.« Leadership \& Organization Development Journal 25 (5): 262.

Houghton, Jeffery D., in Abilene Christian. 2005. »Toward a Contingency Model of Leadrship and Psychological Empowerment: When Should Self-Leadership Be Encouraged.«Journal of Leadership and Organizational Studies I I (4): 65-83.

Hussey, David E. 1995. How to Manage Organisational Change. London: Kogan Page.

Huy, Quy Nguyen. 200r. »Time, Temporal Capability, and Planned Change.« Academy of Management Review 26 (4): 601-23.

ILM - Institute of Leadership \& Management. 2007. Leadership and Management in Organizations. Burlington: Elsevier.

Jelovac, Dejan, in Matjaž Maške. 20ı 2. »An Empirical Study of Transformational Leadership in Slovenian Entrepreneurship.«Innovative Issues and Approaches in Social Sciences 5 (3): 65-82.

Jensen, Ole Bloch. 20I 2. »The Engagement of Employees as a Key Corporate Success.« Dynamic Relationships Management Journal I (2): 45-56.

Jones, Liz, Bordia Prashant, Cindy Gallois in Victor J. Callan. 2008. >Employee Perceptions of Organizational Change: Impact of Hierar- 
chical Level.« Leadership \& Organization Development Journal 29 (4): 294-316.

Kakabadse, Andrew, in Nada Kakabadse. 1999. Essence of Leadership. London: International Thomson Business Press.

Kavčič, Bogdan. I991. Sodobna teorija organizacije. Ljubljana: DZS.

Kee, James Edwin, in Kathryn E. Newcomer. 2008. »Why Do Change Efforts Fail? What Can Leaders Do About It? « The Public Manager, September 2008: 5-I2.

Kotter, John P. 1990. A Force for Change: How Leadership Differs From Management. New York: Free Press.

Kotter, John P. 1998a. Leading Change. Harvard Business Review on Change. Boston: Harvard Business School Publishing.

Kotter, John P. 1998b. Winning at Change. Leader to Leader I0: 27-33.

Kotter, John P. 1998c. »What Leaders Really Do?« V Harvard Review on Leadership, ur. President and Fellows of Harvard College, 37-60. Boston: Harvard Business School Press.

Kouzes, James M., in Barry Z. Posner. 1987. The Leadership Challenge. San Francisco: Jossey-Bass.

Kovač, Bogomir. 1996. Poslovna mitologija. Ljubljana: Gospodarski vestnik.

Kovač, Jure, Janez Mayer in Manca Jesenko. 2004. Stili in značilnosti uspešnega vodenja. Kranj: Moderna organizacija.

Kovač, Jure, Jürgen Mühlbacher in Georg Kodyek. 2012. Uvod v management sprememb. Kranj: Moderna organizacija.

Krištof, Zvonka, Romana Martinčič in Matjaž Vrčko. 2009. »Vodenje.« http://www.impletum.zavod-irc.si/docs/Skriti_dokumenti/ Poslovno_ komuniciranje_in_vodenje-Kristof_Martincic_Vrcko.pdf.

Kuhlmann, Ellen, Viola Burau, Tiago Correia, Roman Lewandowski, Christos Lionis, Mirko Noordegraaf in Jose Repullo. 2013. »A Manager in the Minds of Doctors: A Comparison of New Modes of Control in European Hospitals.« BMC Health Services Research. http://www. biomedcentral.com/1 472-6963/246.

Kurup, Shantha B., in A. Pankajam. 2000. Developing Leaders for 2 Ist Century. The Journal of Business Perspective Special Issue: 57-68.

Larkin, Howard. 2015. »The New Health Care CEO.«Hospitals \& Health Networks 89 (6): 22-27.

Lawrence, Eleanor, Cynthia P. Ruppel in Leslie C. Tworoger. 20I4. »The Emotions and Cognitions During Organizational Change: The Impor- 
tance of the Emotional Work for Leaders.« Journal of Organizational Culture, Communications and Conflict I 8 (I): 257-73.

LeBrasseur, Rolland, Robert Whissell in Abhoy Oyha. 2002. »Organisational Learning, Transformational Leadershi and Implementation of Continuous Quality Improvement in Canadian Hospitals.« Australian Journal of Management 27 (2): 1 4I-62.

Leigh, Andrew. 2009. »Integrity: Are Your Leaders Up to It? «Human Resource Management International Digest i 7 (6): 3-7.

Leong, LaiYin Carmen, in Ronald Fischer. 20I I. »Is Transformational Leadership Universal? A Meta-Analytical Investigation of Multifactor Leadership Questionnaire Means Across Cultures.«Journal of Leadership \& Organizational Studies I 8 (2): 164-74.

LeTourneau, Barbara, in Ann Fleischauer. 1999. »What Physicians Want?《 Healthcare Executive I4 (3): IO-I 4.

Levine, Stuart R., in Michael A. Crom. 2000. Kako uspešno vodimo ljudi. Ljubljana: Mladinska knjiga.

Lipičnik, Bogdan. 1998. Ravnanje z ljudmi pri delu. Ljubljana: Gospodarski vestnik.

Lockitt, William. 2004. »Change Management.« https://web.archive.org/ web/2006roro032354/http://nt.6r39.vs.netbenefit.co.uk/pdf/CHANGEMANAGEMENT 3 t.pdf.

Longenecker, Clinton O., in Paul D. Longenecker. 20r4. »Why Hospital Improvement Efforts

Fail.«Journal of Healthcare Management 59 (2): 147-57.

Lussier, Robert N., in Christopher F. Achua. 2007. Leadership. Theory Application and Skill Development. Ohio: Thompson South - Western.

Majcen, Milena. 2009. Management kompetenc. Izdelava modela kompetenc ter njegova uporaba za razvoj kadrov in za vodenje zaposlenih $k$ doseganju ciljev. Ljubljana: GV Založba.

Marinescu, Paul. 2004. Public Institutions Management. Bucharest: University of Bucharest.

Martin, Jacqueline S., Brendan McCormack, Donna Fitzsimons in Rebecca Spirig. 20 1 4. »Evaluation of Leadership Practices: How to Develop a Vision.« Journal of Research in Nursing I9 (2): 102-15.

Martinčič, Romana. 20I6. »Stili vodenja v procesih spreminjanja: primer slovenskih bolnišnic.« Doktorska disertacija, Univerza na Primorskem.

Mauer, Rick. 201 Ia. »Why Most Changes Fail.« The Journal for Quality and Participation 34 (2): 17-I8. 
Mauer, Rick. 20 I rb. »Why Do So Many Changes Still Fail (Part Two).« The Journal for Quality and Participation 33 (4): 33-34.

Mayer, Janez. 2003. »Lastnosti uspešnih vodij.« Organizacija 36 (6): 36875.

McCrimmon, Mitch. 2005. »Thought Leadership: A Radical Departure from Traditional, Positional Leadership.« Management Decision 43 (7/8): 1064-70.

McGregor, Douglas. 1960. The Human Side of Enterprise. New York: McGraw-Hill.

McGregor, Douglas. 1966. Leadership and Motivation. Boston: MIT Press.

McLean, Christine. 20I I. »Change and Transition: What Is the Difference? « British Journal of School Nursing 6 (2): 78-8 I.

McNulty, Terry, in Ewan Ferlie. 2004. »Process Transformation: Limitations to Radical Organizational Change within Public Service Organizations.« Organization Studies 25 (8): 1389-12.

Menaker, Ronald. 2009. »Leadership Strategies in Healthcare.« The Journal of Medical Practice Management 24 (6): 339-43.

Merriam, Sharan B. 1998. Qualitative Research and Case Study Applications in Education. San Francisco: Jossey-Bass.

Mesec, Blaž. 1998. Uvodv kvalitativno raziskovanje v socialnem delu. Ljubljana: Visoka šola za socialno delo.

Mesiti, Pat. 2003. Povežite se z ljudmi. Ljubljana: Amalietti \& Amalietti.

Michel, Aleksandra, Rune Todnem By in Bernard Burnes. 2013. »The Limitations of Dispositional Resistance in Relation to Organizational Change.« Management Decision 5I (4): 76I-80.

Miles, Matthew B., in A. Michael Huberman. 1994. Qualitative Data Analysis. Thousand

Oaks, London, New Delhi: Sage.

Ministrstvo za zdravje. 20ı6a. »Poročila o poslovanju javnih zdravstvenih zavodov in JAZMP.« http://www.mz.gov.si/fileadmin/mz.gov.si/pageuploads/analize_poslovanja.

Ministrstvo za zdravje. 20r6b. »Resolucija o nacionalnem planu zdravstvenega varstva 2016-2025. 'Skupaj za družbo zdravja.'« http://www.mz.gov.si/fileadmin/mz.gov.si/pageuploads/ResNPZV_16-25/ResNPZV_2016-25_ v2.pdf.

Mittal, Rakesh. 2015. »Charismatic and Transformational Leadership Styles: A Cross-Cultural Perspective.« International Journal of Business and Management Io (3): 26-33. 
Mokhber, Mozdeh, Wan Khairuzzmnan bin Wan Ismail in Amin Vakilbashi. 2015. \Effect of Transformational Leadership and its Components on Organizational Innovation.«Iranian Journal of Management Studies 8 (2): $22 \mathrm{I}-4 \mathrm{I}$.

Mosadegh Rad, Ali Mohammad. 2005. »A Survey of Total Quality Management in Iran. Barriers to Successful Implementation in Health Care Organizations. «International Journal of Health Care Quality Assurance I $8(4 / 5):$ I 2-34.

Mosadegh Rad, Ali Mohammad, in Mohammad Hossein Yarmohammadian. 2006. »A Study of Relationship between Managers' Leadership Style and Employees' Job Satisfaction.« Leadership in Health Services I9 (2): I I-28.

Možina, Stane, Ichak Adizes, Zoran Milivojević, Ivan Svetlik in Milan Terpin. 1996. Človeku prijazno in uspešno vodenje. Ljubljana: Pantha Rhei - Sineza.

Možina, Stane, Bogdan Kavčič, Mitja Tavčar, Danijel Pučko, Štefan Ivanko, Bogdan Lipičnik, Jože Gričar, Leon Repovž, Andrej Vizjak, Aleš Vahčič, Veljko Rus in Rado Bohinc. 1994. Management. Radovljica: Didakta.

Možina, Stane, Rudi Rozman, Miroslav Glas, Mitja Tavčar, Danijel Pučko, Janko Kralj, Štefan Ivanko, Bogdan Lipičnik, Jože Gričar, Metka Tekavčič, Vlado Dimovski in Bogomir Kovač. 2002. Management nova znanja za uspeh. Radovljica: Didakta.

Müller, Ralf, in Rodney Turner. 2007. »Matching the Project Manager's Leadership Style to Project Type.« International Journal of Project Management 25 (I): 2 I-32.

Nordström, Kjell A., in Jonas Ridderstråle. 2001. Ta nori posel. Funky Business. Ljubljana: GV Založba.

Northouse, Peter Guy. 2001. Leadership: Theory and Practice, 2nd ed. Thousand Oaks, London, New Delhi: Sage.

Norton, Bev. 2007. »Being a Leader Through Times of Change.« Clinician in Management I5: II5-I8.

OCR - SiOK. 2016. »Poročilo o merjenju klime.« Projekt primerjalnega raziskovanja organizacijske klime v slovenskih bolnišnicah. Interno gradivo, Klinika Golnik.

Olson, Edwin E., in Glenda H. Eoyang. 2001. Facilitating Organization Change: Lessons from Complexity Science. San Francisco: John Wiley \& Sons, Inc. 
O'Neil, Edward, in Robin Morjikian. 2003. »Nursing Leadership: Challenges and Opportunities.« Policy, Politics \& Nursing Practice 4 (3): 17379.

Ott, Steven J. 2001. Understanding Nonprofit Organizations: Governance, Leadership, and Management. Boulder: Westview Press.

Pardo del Val, Manuela, in Clara Martinez Fuentes. 2003. »Resistance to Change: A Literature Review and Empirical Study.« Management Decision 4 (I/2): I 48-55.

Pardo del Val, Manuela, Clara Martinez-Fuentes in Salvador Roig-Dobon. 2OI 2. »Participative Management and Its Influence on Organizational Change.« Management Decision 50 (10): 1843-60.

Pasmore, William A. 1994. Creating Strategic Change. Designing the Flexible High-Performing Organization. New York: John Wiley \& Sons, Inc.

Paton, Robert A., in James McCalman. 2000. Change Management: A Guide to Effective Implementation. London: SAGE Publications.

Pennington, Gus. 2003. »Guidelines for Promoting \& Facilitating Change.« https:// www.heacademy.ac.uk/ sites/default/files/id 296 Promoting_and_facilitating_change.pdf.

Pointer, Dennis D., in Julianne P. Sanchez. 1993. »Leading in the Midst of a Revolution.« Frontiers of Health Services Management Io (2): 36-40.

Pomey, Marie-Pascale, Andre-Pierre Contandriopoulos, Patrice Francois in Dominique Bertrand. 2004. »Accreditation: A Tool for Organizational Change in Hospitals.« International Journal of Health Care Quality Assurance I7 (3): II3-24.

Porras, Jerry I., and Peter J. Robertson. 1992. »Organizational Development: Theory, Practice in Research.« V Handbook of Industrial and Organizational Psychology, ur. Marvin D. Dunnete in Leaetta M. Hough, 719-822. Palo Alto: Consulting Psychology Press.

Prevodnik, Mojca, in Roberto Biloslavo. 2009. »Managers and Leaders in Organizations of a Post-Transition Economy.« Organizacija 42 (3): 8794.

Pucelj, Mitja, in Borut Likar. 2006. »Vodenje kot ključni dejavnik za ustvarjanje inovacijske kulture.«Organizacija 39 (2): 132-40.

Purvee, Anar, in Dalantai Enkhtuvshin. 2015. »Leadership Behaviours, Trustworthiness, and Managers' Ambidexterity.« International Journal of Innovation, Management and Technology 6 (2): 109-13.

Rees, Gareth H. 2014. »Organisational Readiness and Lean Thinking Implementation: Findings from Three Emergency Department Case Stu- 
dies in New Zealand.« Health Services Management Research 27 (I/2): I-9.

Roach, David W., in David A. Bednar. 1997. »The Theory of Logical Types: A Tool for Understanding Levels and Types of Change in Organizations.« Human relations 50 (6): 67 I-99.

Robbins, Stephen. 1997. Managing Today! New Jersey: Prentice Hall, Inc.

Robida, Andrej, Brigita Skela Savič in Aleš Trunk. 2008. Opredelitev znanj in kompetenc za srednjo upravljalsko raven $v$ bolnišnici: zaključno poročilo raziskovalne skupine. Ljubljana: Mednarodni inštitut za razvoj managementa v zdravstvu.

Rutledge, Tim, in Doug Sinclair. 2013. »Your Profession Needs You (Lessons in Medical Leadership).« Journal of the Canadian Association of Emergency Physicians I5 (2): 67-72.

Sagadin, Janez. 200I. »Pregledno o kvalitativnem empiričnem pedagoškem raziskovanju.«Sodobna pedagogika 52 (2): 10-25.

Sagadin, Janez. 2004. »Tipi in vloga študij primerov v pedagoškem raziskovanju.« Sodobna pedagogika 55 (4): 88-100.

Sayles, Leonard R. 1999. The Working Leader: The Triumph of High Performance Over Conventional Management Principles. New York: Free Press.

Schein, Edgar H. 1992. Organizational Culture and Leadership. San Francisco: Jossey-Bass.

Schein, Edgar H. 2008. Spreminjajoča se vloga kadrovskega managerja. Bled: IEDC - Poslovna šola.

Senge, Peter M. 1990. The Fifth Discipline: The Art and Practice of the Learning Organization. New York: Doubleday.

Shortell, Stephen. M., James. L. Zazzali in Lawton R. Burns. 200I. »Implementing Evidence-Based Medicine: The Role of Market Pressures, Compensation Incentives, and Culture in Physician Organizations.« Medical Care 39 (7): 62-78.

Silverman, David. 2005. Doing Qualitative Research. London: Sage.

Siverbo, Kristian, Henrik Eriksson in Helle Wijk. 20I3. »An Improvement Engine for Empowered change in Healthcare.« International Journal of Productivity and Performace Management 62 (2): 156-67.

Skela Savič, Brigita. 2008. »Ali so potrebne spremembe na področju vodenja zaposlenih v slovenskem zdravstvu? « V Vodenje, motivacija in čustvena inteligenca vodje $v$ zdravstvu. Zbornik predavanj $z$ recenzijo, ur. Brigita 
Skela Savič in Boris Miha Kavčič, 9-28. Bled: Visoka šola za zdravstveno nego Jesenice.

Skela Savič, Brigita, in Milan Pagon. 2007. »Model dejavnikov uspešnega izvajanja sprememb v slovenskih bolnišnicah.« Organizacija 40 (4): 6374.

Smith, Ian. 2005. >Continuing Professional Development and Workplace Learning I I: Managing the 'People' Side of Organisational Change.« Library Management 26 (3): 152-55.

Smith, Ian. 2006. »Continuing Professional Development and Workplace Learning - I5. Achieving Successful Organisational Change - Do's and Dont's of Change Management.« Library Management 27 (4/5): 30006.

Smith, Martin, in Pierre Mourier. 1999. »Implementation: Key to Organizational Change.« Strategy \& Leadership 27 (6): 37-4I.

Stake, Robert. 1995. The Art of Case Study Research. Thousand Oaks: Sage.

Stanley, David. 2006. $\gg$ In Command of Care: Clinical Nurse Leadership Explored.«Journal of Research in Nursing I I (I): 20-39.

Steinke, Claudia, Ali Dastmalchian, Paul Blyton in Paul Hasselback. 2013. »Organizational Change Strategies Within Healthcare.« Healthcare Management Forum 26 (3): I27-35.

Stid, Daniel, in Jeffrey Bradach. 2009. » How Visionary Nonprofits Leaders Are Learning to Enhance Management Capabilities.« Strategy \& Leadership 37 (I): 35-40.

Storr, Lorna. 2004. \Leading with Integrity: A Qualitative Research Study.« Journal of Health Organization and Management i 8 (6): 4I534.

Svetlik, Ivan, in Nada Zupan, ur. 2009. Menedžment človeških virov. Ljubljana: Fakulteta za družbene vede.

Tan, Adrian. 2010. »Time for a Change.« Quality Progress (October). http://asq.org/quality-progress/2010/ro/one-good-idea/time-for-a-change.html.

Tavčar, Mitja. 2000. Strateške razsežnosti managementa. Skripta za podiplomski študij. Koper, Maribor: VŠM in EPF, Inštitut za razvoj managementa.

Tavčar, Mitja, in Nada Trunk Širca. 1998. Management nepridobitnih organizacij. Koper: Visoka šola za management.

Tichy, Noel M., in Marry Anne Devanna. 1990. The Transformational Leader. Toronto: John Wiley \& Sons, Inc. 
Tomlinson, Julie. 2012. »Exploration of Transformational and Distributed Leadership.«Nursing Management I9 (4): 30-34.

Toš, Niko, in Mitja Hafner-Fink. 1998. Metode družboslovnega raziskovanja. Ljubljana: FDV.

Tracy, Brian. 2000. Vrhunsko vodenje. Bled: Vernar consulting.

Trastek, Victor, Neil Hamilton in Emily Niles. 2014. »Leadership Models in Health Care - A Case for Servant Leadership.« Mayo Clinic Proceedings 89 (3): 374-8I.

Tratnik, Monika. 2002. Osnove raziskovanja v managementu. Koper: Visoka šola za management.

Treven, Sonja. 1998. Management človeških virov. Ljubljana: Gospodarski vestnik.

Trowler, Paul, Murray Saunders in Peter Knight. 2003. »Change Thinking, Change Practices. A Guide to Change for Heads of Department, Programme Leaders and Other Change Agents in Higher Education.« https://www.heacademy.ac.uk/sites/default/files/id262_change_thinking_ change_practices.pdf.

Turner, Rodney J., in Ralf Müller. 2005. »The Project Manager's Leadership Style as a Success Factor on Projects: A Literature Review.« Project Management Journal 36 (I): 49-6I.

Verle, Karmen, in Mirko Markič. 201 2. Kompetence vršnih managerjev in organiziranost kot osnova uspešnosti organizacije. Koper: Fakulteta za management.

Walker, Jack H., Achilles A. Armenakis in Jeremy B. Bernerth. 2007. »Factor Influencing Organizational Change Efforts. An Integrative Investigation of Change Content, Context, Process and Individual Differences.«Journal of Organizational Change Management 20 (6): 76I-73.

Walumbwa, Fred, in Weichun Zhu. 2004. Multifactor Leadership Questionnaire. Manual and Sample Set, 3 rd ed. Lincoln: University of Nebraska, Gallup Leadership Institute; Palo Alto: Mind Garden, Inc.

Walumbwa, Fred, Bruce Avolio, William Gardner, Tara Wernsing in Suzanne Peterson. 2008. »Authentic Leadership: Development and Validation of a Theory-Based Measure.«Journal of Management 34 (I): 89I 26.

Washington, Rynetta R., Charlotte D. Sutton in William I. Sauser. 2014. $\gg$ How Distinct is Servant Leadership Theory? Empirical Comparison with Competing Theories.« Journal of Leadership, Accountability and Ethics II (I): I I-25. 
Weil, Thomas P. 2014. »Leadership in Academic Health Centers in the US: A Review of the Role and Some Recommendations.« Health Services Management Research 27 (I-2): 22-32.

Weisinger, Hendrie. 2001. Čustvena inteligenca pri delu z ljudmi. Neizkoriščen vir uspeha. Ljubljana: Tangram.

Werkman, Renate A. 2009. »Understanding Failure to Change: A Pluralistic Approach and Five Patterns.«Leadership \& Organization Developmemt Journal 30 (7): 664-84.

Wittenstein, Robin D. 2008. »Factors Influencing Individual Readiness for Change In a Health Care Environment.« PhD diss., The George Washington University.

Xirasagar, Sudha, Michael E. Samuels in Carleen H. Stoskopf. 2005. »Physician Leadership Styles and Effectiveness: An Empirical Study.« Medical Care Research and Review 62 (6): 720-40.

Yin, Robert K. 1994. Case Study Research. London: Sage.

Yukl, Gary. 1998. Leadership in Organizations. London: Prentice Hall.

Zaersabet, Fatemeh, Jafar Ahangaran in Mehrdad Goudarzvand Chegini. 2013. Empowerment and Leadeship Style with New Approach in Organizations. Arabian Journal of Business and Management Review (OMAN Chapter) 3 (2): 88-93.

»Zakon o zdravstveni dejavnosti.« Uradni list $R S$, št. 23/05 - uradno prečiščeno besedilo.

»Zakon za uravnoteženje javnih financ.«Uradni list $R S$, št. 40/I2; 105/I2.

Zavod za zdravstveno zavarovanje Slovenije. 20I 4. Strateški razvojni program Zavoda za zdravstveno zavarovanje Slovenije za obdobje od 2014-20I9. Ljubljana: ZZZS. 


\section{Recenziji}

Pričujoča znanstvena monografija z naslovom je izdelana na podlagi analize ter sinteze teoretičnih izhodišč in izsledkov raziskav tujih in domačih avtorjev na področju managementa sprememb, s poudarkom na vodenju sprememb v bolnišnicah ter lastne kvalitativno - kvantitativne empirične raziskave. $V$ kvalitativnem delu raziskave podajata globok uvid $\mathrm{v}$ značilnosti procesov spreminjanja ter pristopov $\mathrm{k}$ vodenju sprememb. V kvantitativnem delu empirične raziskave pa sta avtorja koncipirala lasten merski instrument za merjenje vrst sprememb ter merjenje uspešnosti uvedenih sprememb v bolnišnicah. Monografijo zaključita s predlaganim modelom vodenja sprememb v bolnišnicah.

Vodenje sta opredelila kot usmerjanje, motiviranje in vplivanje na zaposlene z namenom, da so naloge čim bolje opravljene, ob čim manjši porabi energije in čim večjem zadovoljstvu vseh udeleženih. Avtorja ugotavljata, da je vodenje sprememb, še posebej velikopoteznih oz. radikalnih (tudi fundamentalnih) najtežja naloga zdravstvenega managementa. Osvetlita procesni vidik vodenja sprememb in predstavita ključne modele managementa sprememb. V sklepnem delu znanstvene monografije pravita, da je upoštevanje obeh vidikov, procesnega in vsebinskega, ključnega pomena za uspešno uvajanje sprememb v zdravstvu. Avtorja ugotavljata, da slovenski zdravstveni managerji uporabljajo vse tri glavne stile vodenja; transformacijsko, transakcijsko in laissez-faire vodenje oz. vodenje brez vajeti. Med izvajanjem sprememb je bila izraženost transformacijskega in transakcijskega načina vodenja v povprečju skoraj enaka. Oba stila sta se izkazala kot uspešna pri uvajanju sprememb, medtem ko se je pasi- 
ven način vodenja izkazal za neuspešnega. Podala sta tudi zanimive rezultate multivariatne regresijske analize, $v$ kateri sta potrdila pozitivno povezanost med pasivnim vodenjem in radikalno temeljnimi spremembami, kar predstavlja določeno presenečenje glede na ostale raziskave v svetu, kjer raziskovalci transformacijskemu stilu vodenja pripisujejo večji uspeh pri uvajanju radikalnih sprememb. Na podlagi rezultatov študije avtorja podata tudi nekaj priporočil za prakso in s tem pomagata zdravstvenim managerjem razumeti učinke uspešnega managementa sprememb. $\mathrm{V}$ znanstveni monografiji sta avtorja povzela bistvene ugotovitve iz opravljene raziskave ter jih primerjala $\mathrm{z}$ ugotovitvami drugih.

Monografija je izdelana na podlagi primarno in sekundarno zbranih informacij o vodenju sprememb v zdravstvenih organizacijah. Znanstvena monografija sestoji iz osem vsebinsko zaokroženih poglavij, ki preko začetnih teoretičnih izhodišč koncipirajo okvir raziskave in preko zbiranja in obdelave podatkov ter njihove analize pripeljejo do ugotovitev lastne empirične raziskave ter sklepa monografije

Namen raziskave je bil razviti načine za učinkovito vodenje sprememb, ki bi vodjem pri izvajanju posameznih korakov v procesih spreminjanja omogočali večjo suverenost pri vodenju. S proučitvijo pristopov in stilov vodenja, ki so v bolnišnicah najbolj povezani s procesi spreminjanja sta avtorja pridobila globok vpogled v vodenje in vrste sprememb v bolnišnicah. Oblikovala sta šest ključnih ciljev, ki med drugim se nanašajo na preučitev in identifikacijo značilnih stilov vodenja sprememb v bolnišnicah ter ugotavljanje morebitne statistične povezanosti stilov z izvajanjem različnih vrst sprememb v slovenskih bolnišnicah. Oblikovala sta temeljna vprašanja za izvedbo polstrukturiranih intervjujev v kvalitativni raziskavi ter sedem raziskovalnih hipotez.

Vsebina dela je aktualna. Pričujoče delo je ustrezno strukturirano. Nabor uporabljene literature je aktualen in dovolj bogat. Uporabljena terminologija je ustrezna.

Prispevek monografije k znanosti lahko razdelimo na teoretičen, empiričen in metodološki. S teoretičnega vidika avtorja strneta pregled in analizo ter kritično ovrednotita raziskave s področja vodenja sprememb $\mathrm{v}$ bolnišnicah. Metodološki prispevek znanstvene monografije je dvojen: prvi se nanaša na kombiniranje kvalitativnih in kvantitativnih raziskovalnih metod, drugi pa na razvoj merskega instrumenta za merjenje štirih vrst sprememb povezanih z zdravstvenimi organizacijami. Empirični prispevek monografije pa je v predlaganem modelu vodenja sprememb v bolnišnicah, ki lahko zdravstvenim managerjem služi kot koristno konceptualno orodje. 
Znanstveno monografijo priporočam za sofinanciranje in izdajo, ker prinaša izvirni prispevek na področju vodenja sprememb in predstavlja pomemben teoretično raziskovalni prispevek $\mathrm{z}$ implikacijami za znanost, stroko in prakso na področju uvajanja sprememb z vsemi posebnostmi zdravstvenih okolij.

\section{Marko Ferjan}

II

Znanstvena monografija $\mathrm{z}$ naslovom Vodenje sprememb v zdravstvenih organizacijah: primer slovenskih bolnišnic je izdelana na podlagi primarno in sekundarno zbranih informacij s področja vodenja in spreminjanja, s poudarkom na zdravstvenih ustanovah ter lastne raziskave avtorjev o stilih vodenja v procesih spreminjanja, ki sta jo izvedla na primeru slovenskih bolnišnic. Teoretičen del znanstvene monografije na osnovi analize in sinteze relevantnih teorij za pričujočo raziskavo predstavlja pomemben teoretičen pregled tega znanstvenega oz. strokovnega področja, ki ga avtorja tudi kritično ovrednotita. Pregled teorije se nanaša na osvetlitev razlike med procesi managementa in procesi vodenja, na razloge za neuspeh in odpore pri uvajanju sprememb. Avtorja predstavita tudi vrste sprememb ter značilnosti nekaterih modelov in stilov vodenja. Dotakneta se kompetenc vodij in pomena čustveno inteligenčnih dejavnikov pri vodenju. V empirični raziskavi sta avtorja uporabila kvalitativno - kvantitativen pristop, ki zahteva veščega raziskovalca. Kvalitativno raziskavo sta izvedla kot eksploratorno študijo, ki je dala poglobljen vpogled v procese spreminjanja oz. odgovore na vprašanje »kako spreminjati« V kvalitativni raziskavi pridobljene informacije so služile kot osnova za načrtovanje in izvedbo kvantitativne raziskave.

Avtorja sta zasnovala štiri vrste sprememb, ki sta jih povezala z različnimi vodstvenimi stili. Opredelila sta spremembe, ki so jih izvajali v slovenskih bolnišnicah in s faktorsko analizo izluščila konstrukte radikalno temeljnih, radikalno perifernih, inkrementalno temeljnih in inkrementalno perifernih sprememb. Prav tako je faktorska analiza določila še konstrukt uspešnosti, za ugotavljanje stilov vodenja pa sta uporabila standardiziran MLQ - $5 \mathrm{X}$ vprašalnik, ki meri transformacijsko, transakcijsko in laissez-faire vodenje. $S$ korelacijsko analizo sta ugotavljala povezanost stilov vodenja $\mathrm{z}$ uspešnostjo uvedenih sprememb. $\mathrm{Z}$ multivariatno regresijsko analizo pa sta avtorja ugotavljala povezanost stilov vodenja s posamezno vrsto sprememb. Avtorja v empirični raziskavi ugotavljata, da so v zadnjem letu pred izvedbo raziskave v bolnišnicah izvajali vse štiri konci- 
pirane vrste sprememb, največ pa inkrementalno perifernih sprememb. V skladu s cilji raziskave sta postavila sedem hipotez.

Monografija je izdelana na podlagi primarno in sekundarno zbranih informacij $s$ področja vodenja sprememb $\mathrm{v}$ zdravstvenih organizacijah ter vrstah sprememb. Znanstvena monografija sestoji iz osmih poglavij, ki jo zaokrožajo kot celoto: od uvoda, preko teoretičnih izhodišč, konceptualizacije raziskave, empiričnega dela in sklepa.

Prispevek monografije $k$ znanosti je večstranski: monografija razširja vedenje o preučevani tematiki, v metodološkem smislu prispeva k oblikovanju merskega instrumenta za merjenje posameznih vrst sprememb, v svojem sklepnem delu pa ponudi zasnovo modela vodenja sprememb v bolnišnicah. Poleg znanstveno teoretične implikacije ima monografija tudi veliko strokovno in praktično vrednost.

Znanstveno monografijo priporočam za sofinanciranje in izdajo, zaradi njenih izvirnih prispevkov na področju zasnove modela vodenja sprememb, novega merskega instrumenta za merjenje sprememb, poglobljene obravnave procesov spreminjanja in odlično strukturiranega ter kritično ovrednotenega teoretičnega okvira.

Samo Pavlin 

8

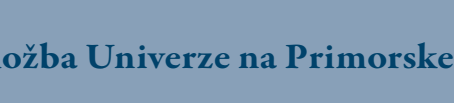

